SERGIO TUTHILL STANICIA

Liberalidade e gratuidade no âmbito da doação

Tese de Doutorado

Orientador: Professor Associado Dr. Bernardo Bissoto Queiroz de Moraes

UNIVERSIDADE DE SÃO PAULO

FACULDADE DE DIREITO

São Paulo - SP

2016 
SERGIO TUTHILL STANICIA

\section{Liberalidade e gratuidade no âmbito da doação}

Tese apresentada a Banca Examinadora do Programa de PósGraduação em Direito, da Faculdade de Direito da Universidade de São Paulo, como exigência parcial para obtenção do título de Doutor em Direito, na área de concentração de Direito Civil, sob orientação do Prof. Associado Dr. Bernardo Bissoto Queiroz de Moraes.

Versão corrigida em 15 de maio de 2016. A versão original, em formato eletrônico (PDF), encontra-se disponível na CPG da Unidade.

UNIVERSIDADE DE SÃO PAULO

FACULDADE DE DIREITO

São Paulo - SP

2016 


\section{SUMÁRIO}

\section{CAPÍTULO I - CAUSA, “ATO” E CONTRATO - A ESTRUTURA CONTRATUAL}

DA DOAÇÃO

1. Sentido jurídico e sentido comum de doação ....................................................20

2. De causa a negócio - a doação no direito romano ..................................................25

1. Origem - a Lex Cincia de donis et muneribus.........................................................25

2. A configuração da doação nos períodos do direito romano ......................................28

3. O "ato" de liberalidade - do direito costumeiro ao Code civil....................................35

1. A ordonnance de 1731 e a doação segundo Domat e Pothier....................................35

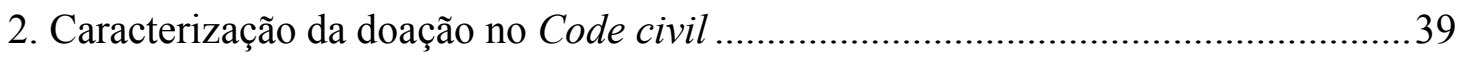

4. O ponto de transição ou contrato sui generis - a doação no CC italiano ................45

1. Ainda sob influência francesa - o Código Civil de 1865 ..........................................45

2. Um novo conceito de doação - o Código Civil de 1942 ...........................................47

5. Contrato em espécie - a doação no Código Civil brasileiro.................................52

1. Das Ordenações Filipinas ao Código Civil de 2002 - alguns aspectos relevantes...52

2. Estrutura bilateral e necessidade de aceitação ........................................................56

6. Contrato real, contrato consensual e contrato preliminar de doação......................60

1. Contrato real ou contrato consensual? .................................................................6 60

2. Contrato preliminar de doação na doutrina e jurisprudência....................................64

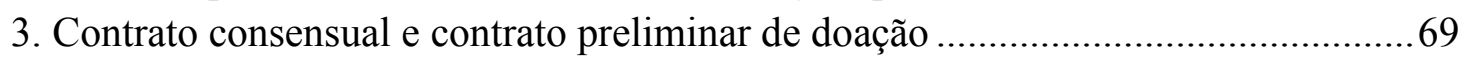

7. Críticas à disciplina jurídica da doação........................................................75

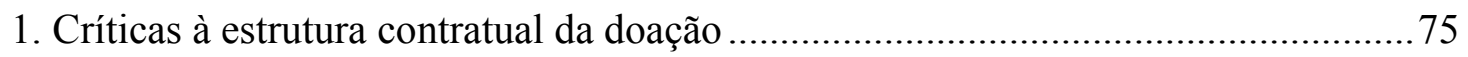

2. Complexidade e manutenção de regras por força da tradição ..................................79

3. Possível inadequação dos conceitos de direito privado e avaliação negativa da

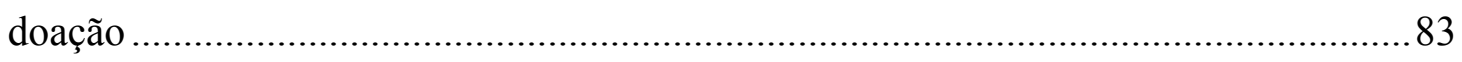

CAPÍTULO II - GRATUIDADE, LIBERALIDADE E DOAÇÃO - TRAÇOS

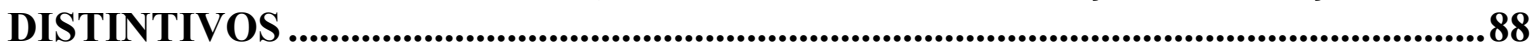

1. Traços distintivos da doação no direito romano ....................................................89

2. Sentidos de "causa" relevantes para o estudo da doação....................................95

1. Sentidos de causa e a causa da obrigação (ou da prestação) .................................... 95

2. Causa do negócio - causa abstrata e causa concreta ..............................................99

3. Notas sobre a identificação do tipo contratual no direito moderno .......................104

4. Doação e contratos gratuitos..............................................................................109

1. Relevância da noção de gratuidade e relação com outras classificações................. 109

2. Critérios distintivos entre a doação e os demais contratos gratuitos ....................... 114

5. Doação indireta - reconhecimento no direito francês e no direito brasileiro ..... 121 
1. A "dessolenização" das liberalidades - doação indireta na França ......................... 121

2. Reconhecimento da categoria das doações indiretas no Brasil ............................... 126

6. Doação indireta e liberalidades diversas da doação no direito italiano................131

1. Doação indireta e negócio indireto - o CC italiano de 1865 .................................. 131

2. Liberalidades diversas da doação - o art. 809 do atual CC italiano ........................ 133

CAPÍTULO III - ENRIQUECIMENTO E ANIMUS DONANDI - ELEMENTOS

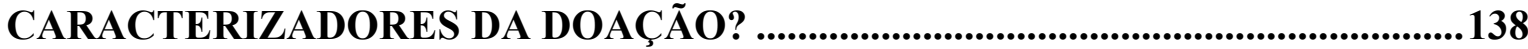

1. Elemento objetivo da doação - enriquecimento e empobrecimento .....................139

1. Doação entre os cônjuges no direito romano......................................................... 139

2. Transferência de bens ou vantagens - art. 538 do CC brasileiro.............................. 141

2. Enriquecimento e admissão das doações de fazer no direito italiano ...................146

1. Enriquecimento nos sentidos econômico e jurídico - o art. 793, 2 do CC italiano 146

2. Prestações de fazer - enriquecimento e empobrecimento ...................................... 150

3. Justificativa e consequências da admissão de doações de fazer ..............................153

3. Elemento subjetivo - animus donandi como traço caracterizador da doação ....157

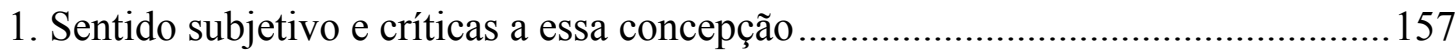

2. Sentido objetivo e a irrelevância do espírito de liberalidade................................... 162

4. Forma prescrita em lei como elemento caracterizador da doação........................166

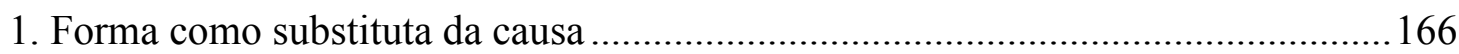

2. Doação como negócio quase abstrato .................................................................. 168

3. Críticas à concepção que dá preponderância à forma como elemento da doação .. 171

5. Espírito de liberalidade entre interesses e deveres ..............................................173

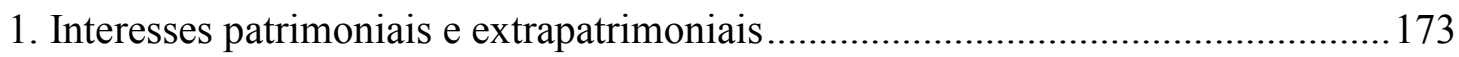

2. Espírito de liberalidade e espírito de solidariedade ................................................ 178

3. Doação e deveres jurídicos e extrajurídicos ......................................................... 181

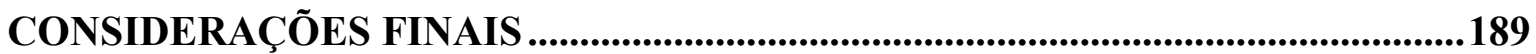

REFERÊNCIAS BIBLIOGRÁFICAS......................................................................194 


\section{RESUMO}

STANICIA, Sergio Tuthill. Liberalidade e gratuidade no âmbito da doação. 2016. 213 p. Doutorado - Faculdade de Direito, Universidade de São Paulo, São Paulo, 2016.

O objeto deste trabalho será analisar criticamente a maneira como o direito conceitua a doação. Será dividido em três partes. O Capítulo I tratará dos diversos modos como a doação foi estruturada no direito romano, no direito francês, no direito italiano e no direito brasileiro, das razões para essa diversidade e possíveis críticas à estruturação atual. O Capítulo II cuidará dos critérios para delimitar a fattispecie da doação e distingui-la dos demais contratos gratuitos. Normalmente, a doutrina identifica um elemento objetivo e um elemento subjetivo como caracterizadores da doação. O Capítulo III problematizará esses elementos, a fim de indagar sobre a abrangência do conceito jurídico de doação, tendo como base dois aspectos: a possibilidade de a doação ter por objeto prestações de fazer e o papel atribuído ao chamado animus donandi.

Palavras-chave: doação; liberalidade; gratuidade; animus donandi; enriquecimento. 


\begin{abstract}
STANICIA, Sergio Tuthill. Liberality and gratuity in the context of gift. 2016. 213 p. Doctorate - Faculty of Law, University of São Paulo, São Paulo, 2016.

The purpose of this thesis is to analize critically the legal concept of gift. It will be divided into three parts. Chapter I covers the different legal structuring of gifts in Roman Law, French Law, Italian Law and Brazilian Law. The chapter also covers the reasons for the existence of different concepts and possibile criticism of the actual structure of gifts. Chapter II deals with the criteria for defining a legal concept of gift and the distinction between gifts and other gratuitous contracts. Generally, legal science identifies an objective element and a subjective element as characteristic features of gifts. Chapter III discusses these elements focused on the magnitude of the legal concept of gift in accordance with two aspects: the possibility of gratuitous services to be considered gifts and the role assigned to the so-called animus donandi.
\end{abstract}

Keywords: gift; liberality; gratuity; animus donandi; enrichment. 


\section{RIASSUNTO}

STANICIA, Sergio Tuthill. Liberalità e gratuità nell'ambito della donazione. 2016. 213 p. Dottorato di ricerca - Facoltà di Giurisprudenza, Universtà di São Paulo, São Paulo, 2016.

Lo scopo di questa tesi sarà analizzare criticamente il modo in cui il diritto definisce la donazione. Sarà divisa in tre parti. Il Capitolo I si occuperà dei diversi modi in cui la donazione fu strutturata nel diritto romano, nel diritto francese, nel diritto italiano e nel diritto brasiliano; si occuperà anche delle ragioni della diversità nel suo concetto e delle possibili critiche alla sua struttura attuale. Il Capitolo II si occuperà dei criteri per la delimitazione della fattispecie della donazione e dei criteri per distinguerla dagli altri contratti gratuiti. In generale, la dottrina ravvisa un elemento oggettivo e un elemento soggettivo per caratterizzare la donazione. Il Capitolo III si occuperà dei problemi derivanti da tali elementi concentrandosi sull'ampiezza del concetto giuridico di donazione secondo due aspetti: l'ammissibilità delle donazioni di fare e il ruolo assunto dal cosiddetto animus donandi.

Parole chiave: donazione; liberalità; gratuità; animus donandi; arricchimento. 


\section{AGRADECIMENTOS}

A realização deste trabalho contou com a fundamental colaboração das seguintes pessoas: Bernardo Bissoto Queiroz de Moraes, pela atenciosa orientação; João Alberto Schützer Del Nero, pelas precisas observações conceituais; Osny da Silva Filho, pelo constante diálogo; Mario Dallari Bucci, pela rigorosa revisão gramatical; Rafael Bianchini Abreu Paiva, pelo auxílio na elaboração de cronograma de execução; Tomás Olcese, pelo apoio durante a banca de qualificação; José Reinaldo de Lima Lopes, pelas importantes indicações bibliográficas; Maria Paula Dallari Bucci e Eugênio Bucci, pelas sugestões acerca da redação final; e Eduardo Cesar Silveira Vita Marchi, pelo incentivo aos estudos.

Agradeço também a Flavia Trentini, Fabio Siebeneichler de Andrade e Carlos Eduardo de Abreu Boucault pela atenta leitura da tese e pertinentes sugestões feitas na banca de defesa.

Agradeço ainda ao desembargador José Tarciso Beraldo, a Lenilda Moraes do Nascimento e a Rafael de Castro Baker Botelho, do Tribunal de Justiça do Estado de São Paulo, pelo apoio durante a fase de elaboração do trabalho, agradecimento que estendo a Eduardo Boccuzzi e a Marco Ferreira Orlandi, de Boccuzzi Advogados Associados.

No plano pessoal, agradeço o apoio incondicional de minha família e amigos. 


\section{SIGLAS E ABREVIATURAS}

$\operatorname{AgRg}=$ Agravo Regimental

AREsp $=$ Agravo em Recurso Especial

art. $=$ artigo

BGB $=$ Bürgerliches Gesetzbuch, in PATTI, Salvatore (org.) - Codice civile tedesco Bürgerliches Gesetzbuch, Milano, Giuffrè-Beck, 2005 (a tradução dos dispositivos que regulam a doação é de GATT, Lucilla).

$B I D R=$ Bullettino dell'Istituto di Diritto Romano "Vittorio Scialoja", Milano, Giuffrè [também Bullettino dell'Istituto di Diritto Romano, Roma, Pasqualucci].

br. $=$ brasileiro $(\mathrm{a})$

C. $=$ Codex Iustinianus

$\mathrm{CC}=$ Código Civil

CDC $=$ Código de Defesa do Consumidor (Lei 8.078, de 11 de setembro de 1990).

Cf. $=$ confrontar

Contratto e impresa $=$ Contratto e impresa - Dialoghi con la giurisprudenza civile $e$ commerciale, Padova, Cedam.

coord. $=$ coordenador $(\mathrm{es})$

C. Th. $=$ Codex Theodosianus

D. = Digesto

Dig. disc. priv., Sez. civ. = Digesto delle discipline privatistiche - Sezione civile, Torino, UTET.

$E D=$ Enciclopedia del diritto, Milano, Giuffrè. 
ed. = edição

EDcl = Embargos de Declaração

Enc. giur. Treccani $=$ Enciclopedia giuridica, Roma, Istituto della Enciclopedia Italiana fondata da Giovanni Treccani.

EREsp $=$ Embargos de Divergência em Recurso Especial

esp. $=$ espanhol (a)

F. V. = Fragmenta Vaticana

Inst. = Institutiones Iustiniani

fr. $=$ francês (a)

ing = inglês (a)

it. $=$ italiano $(\mathrm{a})$

$I U R A=I U R A-$ Rivista internazionale di diritto romano e antico, Napoli, Jovene.

L. Q. Rev. = Law Quarterly Review, London, Stevens and Sons.

$L A B E O=L A B E O-$ Rassegna di diritto romano, Napoli, Jovene.

LINDB $=$ Lei de Introdução às Normas do Direito Brasileiro (Decreto-lei 4.657 de 4 de setembro de 1942).

LRP = Lei de Registros Públicos (Lei 6.015, de 31 de dezembro de 1973).

NNDI = Novissimo digesto italiano, Torino, UTET.

Ord. Filip. = Ordenações Filipinas, Lisboa, Fundação Calouste Gulbenkian (reprodução "fac-simile" da edição feita por Candido Mendes de Almeida, Rio de Janeiro, 1870).

org. $=$ organizador $(\mathrm{es})$ 
port. $=$ português $(\mathrm{a})$

$R D A=$ Revista de direito administrativo, Rio de Janeiro, FGV.

$R D C C=$ Revista de Direito Civil Contemporâneo, São Paulo, RT.

RDPriv $=$ Revista de direito privado, São Paulo, RT.

reed. = reedição

reimpr. $=$ reimpressão

$\mathrm{RE}=$ Recurso Extraordinário

REsp $=$ Recurso Especial

Revista Forense $=$ Revista Forense, Rio de Janeiro, Forense

RFDC $=$ Revista Fórum de Direito Civil, Belo Horizonte, Fórum.

RIDB = Revista do Instituto do Direito Brasileiro, Lisboa, Faculdade de Direito da Universidade de Lisboa.

Riv. crit. dir. priv. $=$ Rivista critica di diritto privato, Napoli, Jovene.

Riv. dir. civ. $=$ Rivista di diritto civile, Padova, Cedam.

Riv. trim. dir. pub. = Rivista trimestrale di diritto pubblico, Milano, Giuffrè.

$\mathrm{STJ}=$ Superior Tribunal de Justiça

$\mathrm{STF}=$ Supremo Tribunal Federal

$S Z=$ Zeitschrift der Savigny-Stiftung für Rechtsgeschichte - Romanistische Abteilung, Weimar.

The Journal of Legal Studies = The Journal of Legal Studies, Chicago, The University of Chicago Press. 
$\mathrm{TJ}=$ Tribunal de Justiça

trad. = tradução

Vita notarile $=$ Vita notarile - Esperienze giuridiche, Palermo, Buttitta. 


\section{CONSIDERAÇÕES INTRODUTÓRIAS E METODOLÓGICAS}

O objeto deste trabalho será analisar criticamente a maneira como o direito conceitua a doação ${ }^{1}$. Será dividido em três partes. O Capítulo I tratará dos diversos modos como a doação foi estruturada no direito romano, no direito francês, no direito italiano e no direito brasileiro, das razões para essa diversidade e possíveis críticas à estruturação atual. O Capítulo II cuidará dos critérios para delimitar a fattispecie da doação e distingui-la dos demais contratos gratuitos. Normalmente, a doutrina identifica um elemento objetivo e um elemento subjetivo como caracterizadores da doação. O Capítulo III problematizará esses elementos, a fim de se indagar sobre a sua abrangência, isto é, sobre que fatos são abarcados ou não pelo seu conceito jurídico, tendo como base duas questões: a possibilidade de a doação ter por objeto prestações de fazer e o papel atribuído ao chamado animus donandi.

A premissa de que parte este trabalho é que o direito seleciona fatos da vida que deseja submeter a uma determinada disciplina jurídica, em razão de política legislativa, e os conceitua por meio de regras constitutivas, efetivamente criando o instituto jurídico da doação. O estudo da delimitação de seu âmbito, portanto, é tão importante quanto o estudo de suas próprias regras regulativas, pois indicará quais são os fatos que serão submetidos a esse regramento ${ }^{2}$.

Embora seja um trabalho focado em doutrina, não negligenciamos a importância da jurisprudência ${ }^{3}$. Porém, em se tratando de um trabalho que foca em regras

${ }^{1} \mathrm{O}$ foco do estudo será a doação dita "pura". Não se tem a pretensão de estudar outras modalidades, como modal, remuneratória, propter nuptias, e nem o negotium mixtum cum donatione. O âmbito do estudo também é limitado ao direito privado (direito civil), embora não se deixe de reconhecer que o tema da doação tem bastante importância em outros ramos do direito, como o tributário, o eleitoral, o administrativo etc. PENTEADO bem aponta que muitos problemas de direito público dependem do conhecimento das categorias de direito privado envolvidas, e sem esse conhecimento "a chance de se cometerem impropriedades é bastante grande", cf. L. C. Penteado, Direito das coisas, $3^{\text {a }}$ ed., São Paulo, RT, 2014, p. 45.

${ }^{2}$ Sobre a distinção entre regras regulativas e regras constitutivas, cf. J. R. L. LOPES, As palavras e a lei - Direito, ordem e justiça na história do pensamento jurídico moderno, Rio de Janeiro, Editora 34, 2004, pp. 34-35.

${ }^{3}$ Será importante fazer referência a julgados do STJ que consideramos relevantes para a construção da noção de doação no Brasil. Essa corte foi selecionada por se tratar do tribunal superior responsável por dar interpretação a lei federal (Constituição da República, art. 105, III), como é o caso do CC. A pesquisa foi efetuada no sítio eletrônico http://www.stj.jus.br [acesso em 15 e 16 de julho de 2015]. Considerou-se mais relevante focar em julgados mais recentes, pois os mais antigos são invariavelmente 
constitutivas e não regulativas, é preciso reconhecer que, em razão da sua finalidade específica de decisão no caso concreto, o papel dos julgados na delimitação de conceitos jurídicos pode ser algo limitado ${ }^{4}$. Além disso, o direito não tem apenas a função de resolver problemas concretos, mas também de orientar e guiar comportamentos e prevenir litígios $^{5}$, de maneira que um foco na jurisprudência não abrangeria a totalidade do fenômeno, mas somente os "casos patológicos"".

Em razão da diversidade ou da semelhança entre os sistemas jurídicos ${ }^{7}$ e dos diferentes ou análogos objetivos visados pela política legislativa, verifica-se que a

referidos pela doutrina que trata do tema. Por essa razão, limitou-se o período da pesquisa a dez anos (acórdãos julgados entre 1 de julho de 2005 e 1 de julho de 2015).

Para a obtenção de julgados relevantes anteriores ao período pesquisado, foram fundamentais as obras de M. C. BODIN DE MORAES, Notas sobre a promessa de doação, in Civilistica.com 2 (2013), passim e D. A. CARNAÚBA - G. H. L. ReINIG, Nulidade da doação e conversão substancial do negócio jurídico - Comentários ao acórdão do REsp 1.225.861/RS, in RDCC 1 (2014), passim. Pelo fato de a doação ter repercussão em outras áreas do direito, e este trabalho ser focado no direito privado, optou-se por limitar a pesquisa aos órgãos julgadores que tratam especificamente dessa matéria. Há, com efeito, três áreas de especialização estabelecidas em razão da matéria (art. $8^{\circ}$ do Regimento Interno do STJ) e compete à Segunda Seção e respectivas turmas (Terceira e Quarta) processar e julgar os feitos relativos ao "direito privado em geral" (Regimento Interno do STJ, art, $\left.9^{\circ}, \S 2^{\circ}, \mathrm{XIV}\right)$. A busca também foi estendida à Corte Especial, que "não está sujeita a especialização" (Regimento Interno do STJ, art. $8^{\circ}$, parágrafo único), mas à qual compete processar a julgar os "incidentes de uniformização de jurisprudência, em caso de divergência na interpretação do direito entre as Seções" (Regimento Interno do STJ, art. 11, VI). Para os propósitos específicos deste trabalho - discussão acerca do conceito de doação, do papel da forma e do animus donandi e da admissibilidade do contrato preliminar de doação - considerou-se relevante efetuar a pesquisa com base nos seguintes parâmetros de "ementa/indexação" (outras palavras-chave foram utilizadas, mas não foram obtidos resultados satisfatórios): Doação e "animus donandi"; Doação e "promessa"; Código Civil de 2002 - art. 538; Código Civil de 2002 - art. 541. Foram obtidos 25 resultados no total. Ao longo do trabalho, porém, só são referidos aqueles que efetivamente trouxeram alguma contribuição para este estudo.

${ }^{4}$ CAREDDA destaca que o fato de a jurisprudência utilizar os conceitos jurídicos com uma postura "utilitarista" na solução dos casos concretos pode empobrecer o seu caráter "científico", tornando a sua contribuição para a real compreensão da figura pouco significativa $\mathrm{cf}$. V. CAREDDA, Le liberalità diverse dalla donazione, Torino, Giappichelli, 1996, p. 94.

${ }^{5}$ Cf. J. R. L. LOPES, Entre a teoria da norma e a teoria da ação, in A. C. STORCK e W. B. LisBOA (org.), Norma, moralidade e interpretação: temas de filosofia política e de direito, Porto Alegre, Linus, 2009, p. 61.

${ }^{6}$ A feliz expressão é de V. CAREDDA, Le liberalità diverse dalla donazione cit., p. 94: "Quelli che emergono sono solamente i casi patologici, a fronte di un'esigenza di fondo della vita di relazione che se realizza ai più diversi livelli". Segundo MONTREDON, aliás, "si tous les litiges ne deviennent pas procès, toutes les relations humains ne deviennent pas litiges" e "la quasi-totalité des libéralités s'executent sans heurts", cf. J. F. MONTREDON, La désonlennisation des libéralités, Paris, LGDJ, 1989, p. 7.

${ }^{7} \mathrm{O}$ autores no âmbito do direito comparado normalmente se referem a sistema jurídico como o direito - em sentido bastante amplo - relacionado a determinado país. O agrupamento entre os sistemas, por sua vez, é o que constitui uma família jurídica, cf., por todos, K. ZWEIGERT - H. KÖTZ, Einführung in die Rechtsvergleichung auf dem Gebiete des Privatrechts, 1971, trad. ing. Tony Weir, Introduction to Comparative Law, $3^{\text {a }}$ ed., Oxford, Oxford University Press, 1998, p. 63 e seguintes. Segundo Berman, o sistema jurídico é um sistema estruturado de arranjos, cuja principal finalidade é fornecer uma direção às pessoas em geral e aos vários departamentos do governo quanto ao que é proibido e permitido. $\mathrm{O}$ autor prefere não adotar uma concepção restrita do direito como um conjunto de normas, mas acentuar a atividade 
construção da doação, tanto na lei quanto na doutrina, apresenta semelhanças e diferenças, conforme o sistema jurídico de que se trate. A doação pode ser estruturada como contrato ou não; pode abranger somente prestações de dar ou também de fazer ou de não fazer; pode implicar a transferência imediata de um bem ao beneficiário ou também o surgimento de uma obrigação de efetuar tal transferência e a liberação de um vínculo; e pode ser concebida com uma maior ou menor ênfase dada ao chamado animus donandi.

Essas diferentes configurações da doação são elaboradas tendo em vista diferentes funções e propósitos que podem corresponder ou não à realidade. Por isso, segundo HYLAND, pode-se dizer que são, em grande medida, imaginárias. Legisladores, doutrinadores e magistrados (“juristas" em sentido amplo) constroem para si um mundo às vezes um mundo como gostariam que fosse, outras vezes um mundo como temem que seja - e imaginam, com base na sua intuição, em suas experiências pessoais e em dados trazidos de outras ciências ${ }^{8}$, o impacto que gostariam de ter nesse mundo. Ocorre, todavia,

jurídica, mais do que as regras jurídicas, entendendo o direito objetivo como um processo vivo de alocação de direitos subjetivos e deveres para resolver conflitos e criar canais de cooperação, cf. H. J. BERMAN, Law and Revolution - The Formation of the Western Legal Tradition, Cambridge, Harvard University Press, 1983, pp. 4-5.

${ }^{8}$ Embora o jurista possa - e em determinados casos até seja recomendável - valer-se dos conhecimentos de outras áreas como a sociologia e a economia, é praticamente impossível haver um controle infalível acerca dos propósitos pelos quais as normas jurídicas são promulgadas e, principalmente, acerca das consequências práticas sociais da sua aplicação, pois é muito difícil medir o impacto que as instituições jurídicas desempenham no mundo real, cf. R. HYLAND, Gifts - A Study in Comparative Law, reed. (2009), New York, Oxford University Press, pp. 74-78 e 102-05. SALAMA e PARGENDLER identificam que, nos últimos cinquenta anos, tem sido crescente o papel do jurista "cientista social", que produz trabalhos que "examinam os efeitos das normas jurídicas no mundo real". Porém, a própria especialização e a divisão do trabalho fazem com que esses juristas muitas vezes não lidem facilmente com ferramentas metodológicas de outras áreas, o que pode facilmente acarretar a transformação de "bons juristas em maus economistas ou maus sociólogos", cf. B. M. SALAMA - M. PARGENDLER, Direito e consequência no Brasil - Em busca de um discurso sobre o método, in RDA 262 (2013), p. 130. Além disso, e talvez de modo mais importante, por mais que o jurista se sirva desse aparato empírico, a maneira como deliberará (sobre o direito como "deliberação segundo regras jurídicas", cf. J. R. L. LOPES, As palavras e a lei cit., p. 40) não será uma consequência necessária dos resultados dos estudos empíricos, cf. B. M. SALAMA - M. PARGENDLER, Direito e consequência no Brasil cit., pp. 135-36. Ao contrário, pode haver uma total discrepância entre o pensamento de determinados juristas e os dados fornecidos por outras ciências. A busca por uma relação de causalidade entre as normas jurídicas e seus efeitos no mundo tem sido uma grande crítica ao funcionalismo (cf. nt. 9, infra). Por um lado, as experiências de outros países podem servir como um interessante laboratório, por exemplo, para propostas de mudanças na legislação, de modo que o direito comparado pode demonstrar os efeitos positivos de determinadas regras ou até mesmo reforçar ou aliviar medos quanto aos efeitos negativos de outras, cf. G. DANNEMANn, Comparative Law cit., p. 397. O autor exemplifica que, em determinadas situações, como por exemplo na determinação da redução do limite de velocidade em uma rodovia, pode ser útil averiguar se em outros países uma mesma alteração no limite de velocidade produziu menos acidentes. A utilidade disso é maior em situações em que diferenças no contexto cultural, social, histórico, econômico exercem menos interferência. Porém, ainda assim pode ser difícil estabelecer a relação de causalidade com suficiente certeza. Muitas vezes, as diferenças históricas, econômicas, sociais, 
que é extremamente difícil analisar até que ponto os problemas que esses juristas imaginam são reais e até que ponto as normas criadas para resolvê-los terão o impacto imaginado como resposta necessária à realidade social; em outras palavras, é muito difícil estabelecer uma relação direta entre a norma e os problemas existentes na realidade da vida ${ }^{9}$.

Por essa razão, este trabalho não tem a pretensão de estabelecer em termos absolutos qual é o conceito jurídico de doação que melhor atende às necessidades da sociedade, mas o objetivo, mais modesto, de melhor compreender a visão do direito sobre

geográficas, políticas e culturais dos contextos dos países são tão grandes que é impossível tirar conclusões razoavelmente seguras sobre os efeitos sociais de determinadas regras fora de seu contexto original, cf. G. DANnemann, Comparative Law cit., pp. 397-98. No referido exemplo da redução de velocidade, o autor faz a ressalva de que aspectos culturais podem influenciar a maneira como os condutores dirigem seus veículos em diferentes países, de modo que o resultado obtido em um país pode não se produzir, necessariamente, no outro.

${ }^{9}$ A afirmação feita no corpo do texto tem como pano de fundo uma questão é a base de todas as discussões metodológicas em direito comparado (Cf. R. MiCHAELS, The Functional Method of Comparative Law, M. REIMANN - R. ZIMMERMANN [org.], The Oxford Handbook of Comparative Law cit., 340-41). Trata-se do acolhimento ou da crítica ao funcionalismo, método dominante durante boa parte do século XX (Cf. G. DANnEMAnN, Comparative Law - Study of Similarities or Differences , in M. REIMANN R. ZIMMERMANN [org.], The Oxford Handbook of Comparative Law cit., 2008, p. 386) e cujos pressupostos normalmente são extraídos de um capítulo introdutório da obra de ZWEIGERT e KÖTZ, intitulado "The Method of Comparative Law" (Cf. K. ZWEIGERT - H. KÖTZ, Introduction to Comparative Law cit., pp. 3247). O funcionalismo ancora-se nos seguintes pontos: (i) o interesse na comparação não deve ser pelas regras jurídicas enquanto tais, mas pelas soluções que os sistemas jurídicos apresentam para problemas práticos, de maneira que o direito deve ser estudado segundo sua relação funcional com a sociedade, normalmente com base em decisões judiciais; (ii) presume-se que as sociedades modernas enfrentam problemas semelhantes e que esses problemas serão resolvidos de maneira semelhante (presumptio similitudinis); ainda que sejam utilizados conceitos e soluções doutrinárias diferentes, essa não coincidência é uma mera aparência; (iii) a função é um tertium comparationis, ou seja, os institutos jurídicos são comparáveis na medida em que sejam funcionalmente equivalentes, ou seja, desempenhem funções similares em diferentes sistemas jurídicos. Por todos, cf. R. HYLAND, Gifts cit., 2011, pp. 63-68, R. MiCHAELS, The Functional Method of Comparative Law cit., pp. 341-42 e G. DANNEMANN, Comparative Law cit., pp. 388-89. Embora o método seja adequado para atingir determinados objetivos (a presumptio similitudinis é especialmente útil para projetos de unificação do direito privado, por exemplo, cf. G. DANNEMANN, Comparative Law cit., p. 389) é problemática, segundo HYLAND, a visão de que todas as sociedades desenvolvidas enfrentam os mesmos problemas e que o direito é concebido para resolvê-los. A norma jurídica surge a partir de uma interface de fatores muito complexos, como a história, o costume, idiossincrasias linguísticas, a ética religiosa dominante, supostas necessidades sociais e o favorecimento de determinadas pessoas ou grupos econômicos. Os problemas sociais seriam substancialmente diferentes de uma sociedade para a outra, pois moldados pela história, cultura, religião, idioma, tradição jurídica e inúmeros outros fatores. Muitas vezes somente após a existência da norma é que ocorre uma atribuição imaginária de um propósito aceitável, numa tentativa de justificá-la racionalmente. Assim, embora seja possível atribuir algum propósito racional às normas, esse propósito não é inerente a elas, tanto que normalmente é reformulado com o passar do tempo, cf. R. HYLAND, Gifts cit., pp. 69-75. Justamente por isso, aliás, FERRAZ Jr. adverte que para se chegar aos propósitos e finalidades da norma não basta a busca por aspectos genéticos relacionados ao contexto em que a norma foi criada, mas se deve também interpretá-la conforme as condições específicas do tempo em que "incide”, cf. T. S. FERRAZ Jr., Introdução ao estudo do direito - Técnica, decisão, dominação, 4ª ed., São Paulo, Atlas, 2003, pp. 266-67 e 290-92. 
si mesmo, isto é, como o direito desenvolveu o conceito de doação para atingir os objetivos que almeja. Nesse sentido, a análise feita não será tanto em termos de utilidade, mas de significado ${ }^{10}$.

Logicamente, porém, pelo fato de habitarmos esse mundo imaginário dos juristas, não podemos nos eximir de tomar também algumas posições dogmáticas acerca da construção da noção jurídica de doação, da mesma forma que os juristas que nos antecederam. Embora isso possa parecer paradoxal em relação ao afirmado no parágrafo anterior, ao contrário do mundo das fábulas, o mundo dos juristas tem consequências sérias e graves em função de seu caráter normativo. Por essa razão, um estudo meramente descritivo pouco serviria para auxiliar o operador do direito na sua tarefa de deliberar segundo o caso concreto ${ }^{11}$.

O objetivo deste trabalho, assim, através do estudo em conjunto da doutrina pátria e estrangeira, principalmente italiana ${ }^{12}$, será lançar luz sobre aspectos que envolvem o conceito jurídico de doação que talvez mereçam ser tratados na literatura nacional com mais profundidade ${ }^{13}$, inclusive para que se possa examinar mais criticamente a disciplina jurídica e até eventualmente propor alterações, com o fím último de regular, de uma maneira mais justa, as condutas humanas ${ }^{14}$. Trata-se, assim, mais de um trabalho de

${ }^{10}$ Nesse sentido, o estudo aproxima-se da história. GoRLA já afirmava que "la comparazione, quale metodo, non è che storia, poichè vuol intendere come il fenomeno giuridico si spieghi, si differenzi, si particolareggi in ciascun ordinamento", cf. G. GORLA, Il contratto I - Problemi fondamentali trattati con il metodo comparativo e casistico - Lineamenti generali, Milano, Giuffrè, 1954, p. v. Para HYLAND, as normas jurídicas e as categorias doutrinárias devem ser analisadas da maneira em que se encontram, e sem a pretensão de que realmente sirvam aos seus propósitos, cf. R. HYLAND, Gifts cit., pp. 106-07 e G. DANnEMAnN, Comparative Law cit., pp. 399-400 e 406. No caso da doação, segundo HYLAND, deve-se perguntar quais são os "medos" que provocam nos juristas, como tais medos levam à criação de normas e como a prática que visa a contornar essas normas influencia o próprio direito. cf. R. HYLAND, Gifts cit., pp. 115-18.

${ }_{11}^{11}$ Agradecemos a Osny da Silva Filho por chamar a nossa atenção a respeito desse aspecto.

${ }^{12}$ Sobre a importância do direito italiano para o estudo da doação, cf. R. HYLAND, Gifts cit., p. 192. Direito romano e direito francês serão tratados de maneira secundária, e algumas referências ao direito português, alemão e a outras legislações estrangeiras serão feitas apenas a título de ilustrar alguns pontos, sem pretensão de esgotamento.

${ }^{13} \mathrm{O}$ exame de direito estrangeiro é particularmente útil para detectar "pontos cegos" difíceis de ser encontrados quando o direito é analisado a partir de um ponto de vista interno, cf. G. DANNEMANN, Comparative Law cit., p. 391.

${ }^{14}$ É preciso deixar claro que o objeto da ciência do direito não é a especulação ou contemplação de normas jurídicas. O saber jurídico é prático e normativo, promovendo a "deliberação segundo regras jurídicas". Trata-se da "ciência ou arte de decidir e de ensinar a decidir segundo normas jurídicas", ou seja, tem uma finalidade prática de deliberação e decisão. Além disso, as normas jurídicas "não explicam nem descrevem a realidade": "embora se possa entender melhor uma formação social quando se 
abertura do que de fechamento, que se espera sirva ao leitor como ponto de partida para novas indagações e futuras pesquisas ${ }^{15}$. PENTEADO, referindo-se a um trecho de Guimarães Rosa - "o livro pode valer pelo muito que nele não deveu caber", aponta que inclusive "pelo que no livro não coube" pode-se "colaborar com o resgate do estudo do direito privado" $"$.

leva em conta o sistema jurídico", o direito não explica a formação social, cf. J. R. L. LOPES, As palavras e a lei cit., pp. 39-43. LOPES destaca que "há duas diferentes maneiras de conceber o núcleo de uma teoria do direito - uma teoria das normas e uma teoria da decisão" e "ao nos concentrarmos no que são as normas antes que no que fazem os juristas com as normas, teremos do direito uma certa ideia: a ideia de que o direito é uma 'coisa', algo, talvez mesmo um texto. O jurista parece exercer a atividade de descrever ou falar sobre os textos (as proposições jurídicas)", cf. J. R. L. LOPES, Entre a teoria da norma e a teoria da ação cit., pp. 43-44. Ao se tratar de conceitos, classificações e categorias abstratas em geral, corre-se sempre o risco de se perder em meio a essas noções, esquecendo-se da sua relevância prática. Esse é um erro comum, cometido muitas vezes por uma linguagem manualística característica de muitas obras jurídicas, cf. J. R. L. LoPES, Regla y compás, o metodología para un trabajo jurídico sensato, in C. COURTIS (org.), Observar la leyEnsayos sobre metodología de la investigación jurídica, Madrid, Trotta, 2006, p. 52 (especificamente sobre o "estilo dos manuais") e passim (a obra trata amplamente dessas questões). A busca pela atribuição de um caráter "científico" para o direito fez com que os juristas se inspirassem na antiga biologia, ou história natural, na qual prediminavam os "esforços de classificação, tipificação e desenvolvimento orgânico das espécies", cf. J. R. L. LOPES, As palavras e a lei cit., p. 42. Esse hábito não se restringe à doutrina. DE NOVA, por exemplo, aponta não serem raras as sentenças que, muito embora a qualificação seja irrelevante para a solução da controvérsia, alongam-se na discussão sobre se determinado contrato pertence a um ou a outro tipo, em expressão de verdadeira "mentalidade classificatória", cf. G. DE NOVA, Il tipo contrattuale cit., pp. $9-10$.

${ }^{15}$ Embora os temas aqui tratados tenham sido examinados por muitos autores pátrios, não se tem conhecimento de outro trabalho sobre doação em língua portuguesa que tenha feito recorte semelhante ao que aqui se adotou. Nesse sentido, a afirmação que consta do corpo do texto é bastante sincera. Esta tese tangencia temas bastante complexos e não tem a pretensão de "resolvê-los" de uma maneira definitiva. As conclusões são sempre provisórias e se espera que, seja pela concordância, seja pela discordância, este estudo estimule o debate e eventualmente "abra os olhos" do leitor para questionamentos que talvez não tenham sido suficientemente canalizados pela doutrina civilista brasileira.

${ }^{16}$ Cf. L. C. PENTEADO, Direito das coisas cit., p. 48 e nt. 14. 


\section{CAPÍTULO I - CAUSA, “ATO” E CONTRATO - A ESTRUTURA CONTRATUAL DA DOAÇÃO}

Este capítulo trata basicamente de três grandes temas diversos, porém relacionados. A primeira parte (I.1) é dedicada a esclarecer em que consiste falar em um conceito jurídico de doação em oposição ao sentido comum desse vocábulo. A segunda parte (I.2 a I.6) trata das diferentes maneiras através das quais o direito estruturou a doação nos direitos romano, francês, italiano e brasileiro, seja no que se refere à contratualidade (ou não), seja no que diz respeito às prestações que ela abrange (in dando, in obligando e in liberando). Serão destacadas também as diferentes exigências de forma para o instituto. Especificamente com relação ao direito brasileiro, serão explorados três temas relevantes: a necessidade de aceitação, a questão sobre se a doação é contrato consensual ou real, e a admissibilidade do contrato preliminar de doação. A terceira parte (I.7) será dedicada a possíveis críticas sobre a maneira como o direito estrutura a doação. 


\section{Sentido jurídico e sentido comum de doação}

Embora a noção de doação na vida seja aparentemente simples e intuitiva, quando se passa para o campo da ciência, logo se percebe que os estudiosos de diferentes disciplinas evocam áreas de significado somente em parte coincidentes, e a extensão do fenômeno também varia de maneira considerável ${ }^{17}$. A clássica obra de MAUSS, por exemplo, indica uma maneira diversa de entender a "doação" (ou "dádiva" - em francês, "don"), que vem do ponto de vista das ciências sociais. Tal noção é relevante para tomarmos consciência sobre a existência de sentidos não jurídicos de doação, isto é, para outros ramos do saber.

Ao estudar "a forma e razão da troca nas sociedades arcaicas", o estudioso adota um sentido bastante amplo de "dádivas", que não seriam "exclusivamente bens e riquezas, móveis e imóveis, coisas úteis economicamente", mas "amabilidades, festins, ritos, serviços militares, mulheres, crianças, danças, festas, feiras cujo mercado não é senão um de seus momentos"18. LÉVY-STRAUSS, sobre a obra, aponta que "os bens em questão não são apenas objetos físicos, mas também dignidades, cargos, privilégios, cuja importância sociológica é todavia a mesma dos bens materiais"19.

A obra de MAUSS, aliás, é muito pertinente, pois prenuncia várias questões que acabam sendo enfrentadas ao se analisar a concepção jurídica da doação. O autor se propõe a estudar o fato de que em muitas civilizações "as trocas e os contratos fazem-se sob a forma de presentes, em teoria voluntários, na realidade obrigatoriamente dados e retribuídos" ${ }^{20}$. Do ponto de vista da moral, o autor ressalta que a "dádiva não retribuída torna ainda inferior aquele que a aceitou, sobretudo quando é recebida sem espírito de retorno", como no caso da caridade e da esmola ${ }^{21}$. Essa ideia de obrigatoriedade da

\footnotetext{
${ }^{17}$ Cf. G. CONTE, Il contratto di donazione tra liberalità e gratuità, in G. BonILINI (org.), Trattato di diritto delle successioni e donazioni VI - Le donazioni, Milano, Giuffrè, 2009, p. 3.

${ }^{18} \mathrm{Cf}$. M. MAuss, Essai sur le don-Forme e raison de l'échange dans les societés archaïches, Paris, PUF, 1950, trad. port. A. F. Marques, Ensaio sobre a dádiva - Forma e razão da troca nas sociedades arcaicas, Lisboa, Edições 70, 2011, pp. 55-58. A obra foi originalmente publicada no periódico L'Année sociologique (1923-1924).

${ }^{19}$ Cf. C. LÉVy-STRAuss, Introdução à obra de Marcel Mauss, in M. MAUSS, Ensaio sobre a dádiva cit., p. 34.

${ }^{20}$ Cf. M. MAUSs, Ensaio sobre a dádiva cit., p. 55. Além de uma obrigação de retribuir, MAUSS fala ainda em uma obrigação de receber a dádiva (p. 70).

${ }^{21}$ Cf. M. MAUSs, Ensaio sobre a dádiva cit., p. 195.
} 
retribuição da dádiva denota alguma incoerência com a ideia jurídica da gratuidade e principalmente de ausência de sinalagma ${ }^{22}$.

Neste tópico, o aspecto relevante é chamar atenção para a diversidade de sentido da doação, tanto seu sentido vulgar, quanto aquele usado por outras ciências. De acordo com FERRAZ Jr., as normas jurídicas, na disciplina da conduta humana, utilizam palavras que expressam o sentido daquilo que deve ser, e há uma oscilação entre o "uso corrente para a designação de um fato", que chama de aspecto onomasiológico, e a "sua significação normativa", que é o aspecto semasiológico. Embora tais aspectos possam coincidir, isso nem sempre ocorre. O legislador utiliza vocábulos da linguagem cotidiana e muitas vezes lhes atribui um sentido técnico, que "não é absolutamente independente, mas está ligado de algum modo ao sentido comum, sendo, por isso, passível de dúvidas que emergem da tensão entre ambos" ${ }^{, 23}$.

No caso da doação, para HYLAND, o conceito jurídico coincide menos com a linguagem comum do que no caso de outros conceitos de direito privado ${ }^{24}$. Segundo BIONDI, tal discrepância entre o sentido comum e o jurídico da doação teve início com a alteração da configuração da doação no direito romano operada na época de Constantino ${ }^{25}$, a qual tomou alguns atos qualificados especificamente como doação e os submeteu a uma especial disciplina jurídica, deixando de fora outros, que embora possuíssem o mesmo caráter de "liberalidade", não eram considerados doação ${ }^{26}$.

Essa discrepância fica evidente com a inclusão de definições jurídicas nas codificações. LOPES destaca esse aspecto como "típico da modernidade", e um "fator de importância determinante na elaboração e uso dos conceitos jurídicos”. Se estes antes estavam no campo do ensino, da doutrina e da dogmática jurídica, passaram a integrar a legislação positiva, os códigos e constituições. Assim, categorias jurídicas que antes eram

\footnotetext{
${ }^{22}$ Cf. II.4.1.

${ }^{23}$ Cf. T. S. FerRaz Jr., Introdução ao estudo do direito cit., p. 255.

${ }^{24}$ Cf. R. HYLAND, Gifts cit., p. 10.

${ }^{25}$ Cf. I.2.2.

${ }^{26}$ Cf. B. BIONDI, Le donazioni, in F. VASSALLI (coord.), Trattato di diritto civile italiano XIIIV, Torino, UTET, 1961 p. 10.
} 
tratadas somente pela ciência do direito, passaram a ser incorporadas nos textos legislativos ${ }^{27}$.

Em curiosa passagem dos trabalhos preparatórios do Código Civil francês, verifica-se que a conveniência de trazer uma definição de doação não era unânime na sessão do Conselho de Estado que discutiu a redação do art. 894 do CC francês. Venceu, como se pode verificar a partir da redação do dispositivo, até hoje inalterada e em vigência, a corrente favorável às definições ${ }^{28}$. Em sentido desfavorável estavam REGNAUD, GALLI e BÉRENGER.

O primeiro reputava as definições inúteis, o segundo, fora de lugar em um $\mathrm{CC}$, e o terceiro ponderava que não pertenciam ao domínio da lei. Por serem extremamente difíceis, seria perigoso colocá-las em um código, pois se contêm vícios, podem levar à extração de falsas consequências. Favoráveis à inclusão, por outro lado, estavam os redatores do Código TRONCHET e PORTALIS. O primeiro apontava que o CC não seria redigido somente para juízes e jurisconsultos, mas para todos os cidadãos, de maneira que a inclusão da definição atenderia ao dever de informar a qualquer um quais são os efeitos de uma doação.

PORTALIS, por outro lado, observava que as antigas ordonnances ${ }^{29}$ na França não continham definições. Elas não eram códigos, isto é, repertórios completos de leis sobre toda a matéria, e isso supunha que as doações já estavam definidas pelos costumes e pelo direito comum. Porém, na medida em que o CC buscava substituir o direito escrito e

${ }^{27}$ J. R. L. LOPES, As palavras e a lei cit., São Paulo, Editora 34, 2004, p. 22. IRTI destaca que o legislador pode se valer de dois modos ou técnicas: pode simplesmente disciplinar o fenômeno, atribuindo a ele um nome técnico, mas sem enunciar uma definição. Pode, ao contrário, definir o fenômeno além de simplesmente lhe atribuir um nome, cf. N. IRTI, Introduzione allo studio del diritto privato, Padova, Cedam, 1990 , p. 79.

${ }^{28}$ É interessante notar que a sessão do Conselho de Estado em questão foi presidida por Napoleão, e não pelo Segundo Cônsul Cambacérès, o qual havia manifestado, em outra ocasião, total aversão à inclusão das definições em geral no Code civil, ocasionando a supressão da maior parte do Título Preliminar do projeto, cf. J. GILISSEN, Introduction historique au droit-Esquisse d'une histoire universelle du droit. Les sources du droit. Les sources du droit depuis le XIII. ${ }^{e}$ siècle. Élements d'histoire du droit privé, Bruxelles, Émile Bruyant, 1979, trad. port. de A. M. B. Hespanha e M. L. M. Malheiros, Introdução histórica ao direito, $4^{\mathrm{a}}$ ed., Lisboa, Fundação Calouste Gulbenkian, 2003, pp. $452-53$.

${ }^{29}$ Cf. I.3.1. Segundo GILISSEN, “muitas vezes, 'ordonnances' poderia ser traduzido por 'lei', mas a adoção sistemática desta tradução conduziria, em alguns casos, a anacronismos ou a confusões", Cf. J. GILISSEN, Introdução histórica ao direito cit., pp. 247-48, 251, 254 e 291, nt. *. Poder-se-ia talvez traduzir o termo por "ordenações", mas preferiu-se neste trabalho utilizar o termo original em francês para ressaltar o contexto bastante específico em que se inserem tais legislações. 
os costumes, ele deveria necessariamente trazer definições, pois estas não eram puramente científicas, mas também positivas, e deveria prevalecer a vontade positiva do legislador ${ }^{30}$.

A afirmação chama atenção para o fato de que as definições jurídicas não são léxicas, isto é, não descrevem a essência de algo que se encontra na realidade física e concreta, mas são estipulativas, ou seja, constituem o sentido de determinado vocábulo, determinando seu uso dentro da linguagem ${ }^{31}$. Nesse sentido é a afirmação de BIGOTPRÉAMENEU de que as definições é que eram as verdadeiras disposições de lei, as fundamentais.

LOPES ressalta que o direito tem uma existência virtual, ou seja, só existe por meio da linguagem. Assim, ao definir o que é doação, o direito cria e constitui a doação. Não se trata de simplesmente dar um nome a alguma coisa, mas de constituir, qualificar e

${ }^{30}$ A ata da sessão (do dia 7, do mês "pluviose" do ano XI), pode ser encontrada em P. A. FENET, Recueil complet des travaux préparatoires du code civil XII, Paris, Videcoq, 1836, pp. 261-63. Copiamos os trechos dos quais foram extraídas as informações que constam no corpo do texto: "M. Regnaud (de Saint-Jean-d'Angely) pense que les définitions sont inutiles, puisqu'elles ne sont pas des dispositions dans la loi. (...) M. Galli est d'avis de supprimer les définitions ; elles lui semblent déplacées dans un Code civil. Les Constitutions du Piémont, qui ont été indiquées au grand Frédéric comme un modèle parfait, sont dégagées de toute définition. La loi en effet ne doit définir que les choses sont elle veut changer la nature : c'est dans le Digeste qu'il faut aller chercher les autres définitions. Il paraît aussi que la Constitution de Milanavait déjà suivi cette même marche. (...) M. Bérenger dit que les définitions appartiennent à la jurisprudence, et non à la loi ; elle sont très-difficiles. Il est donc dangereux de les placer dans un Code ; car, si elles étaient vicieuses, elles conduiraient à de fausses conséquences. Les définitions sont le résultat des dispositions du Code, elles sont donc du domaine de la science : or le Code est le fait du législateur (...). M. Tronchet ajoute que le Code civil n'est pas rédigé pour les juges seuls et pour les jurisconsultes, mais pour éclairer tous les citoyens. Il faut donc que chacun y puisse apprendre quel sont les effets de la donations qu'il lui ets permis de faire (...) M. Bigot-Préameneu répond que les définitions sont de véritables dispositions, et même les dispositions fondamentales de la loi ; car elles fixent les incertitudes qui peuvent naître de la diversité des autres dispositions (...) M. Portalis observe que (...) en France, les ordonnances ne contenaient pas des définitions ; mais c'est parce que, n'étant pas des Codes, c'est-à-dire des recueils complets des lois de la matière, elles supposaient que les donations et les testamens se trouvaient déjà définis par les coutumes ou par le droit commun. Auhourd'hui qu'on rédige un Code destiné à remplacer le droit écrit et les coutumes, on ne peut se dispenser de définir parce que ce lois abrogées ne devant pas désormais être enseignées dans les écoles, rien ne donnerait plus une idée précise de la chose, si elle n’était expliquée par le Code civil. (...) M. Portalis dit que les définitions de droit ne sont pas purement scientifique, elle sont positives. Dans les sciences ordinaires, tout est de doctrine et de raison : dans la législation, rien n'existe que par la volonté positive du législateur".

${ }^{31}$ Cf. J. R. L. LOPES, As palavras e a lei cit., p. 27-35. ENGISCH, no mesmo sentido, aponta que o conceito jurídico se distingue do conceito natural ou sociocultural. Ainda que se refiram a exatamente a mesma entidade, o jurídico tem um "alcance particular", pois "funciona como 'hipótese legal' à qual a 'regra de direito' (a 'norma jurídica') liga ‘consequências jurídicas””, cf. K. ENGISCH, Einführung in das Juristische Denken, $8^{\mathrm{a}}$ ed., Stuttgart, Kohlhammer, 1983, trad. port. J. B. Machado, Introdução ao pensamento jurídico, $10^{\mathrm{a}}$ ed., Lisboa, Fundação Calouste Gulbenkian, $10^{\mathrm{a}}$ ed., 2008, pp. 25-27. Segundo IRTI, quando o direito define um fenôneno, não está a descobrir, traduzir ou descrever uma essência, natureza ou conteúdo ontológico, mas a escolher e compor, com absoluta liberdade, os elementos da fattispecie à qual poderá atribuir um nome, cf. N. IRTI, Introduzione allo studio del diritto privato cit., pp. 78-79. 
valorar. Nesse sentido, a regra do art. 894 do CC francês (assim como, por exemplo, a do art. 769 do CC italiano e a do art. 538 do CC brasileiro, que trazem igualmente definições de doação) não é meramente regulativa, ou seja, não se limita a estabelecer o que é proibido, obrigatório ou permitido com relação a fatos alheios a ela própria. É uma regra constitutiva, sem a qual o fato a que se refere simplesmente não existe ${ }^{32}$.

Essa distinção será relevante para este trabalho, pois será identificada a incerteza do conceito jurídico de doação - que não é adotado pelo direito, mas criado pelo direito - e como diferentes ordens jurídicas abarcaram esse fato da vida aparentemente simples de maneiras tão diversas ${ }^{33}$.

Além disso, diante de um conceito jurídico, não se pode esquecer o contexto no qual se insere, entendido o contexto como o ordenamento jurídico e a época histórica. Embora o vocábulo seja o mesmo, a doação no direito brasileiro é diferente da doação no direito italiano, no direito francês e no antigo direito romano. LOPES chama atenção para a "historicidade dos discursos": todo conceito pode ser investigado quanto à história da linguagem, pois o mesmo termo pode ocultar diferentes sentidos e práticas ${ }^{34}$.

Conforme o autor, fala-se em identificar os elementos do tipo (DE NOVA), o cerne e os elementos completantes do núcleo do suporte fático da norma (MELLO) ou os elementos categoriais inderrogáveis (JUNQUEIRA DE AZEVEDo) ${ }^{35}$. Porém, no fundo, o que se busca é essencialmente identificar como o direito cria determinado instituto jurídico através de uma definição estipulativa.

\footnotetext{
${ }^{32}$ Cf. J. R. L. LOPES, As palavras e a lei cit., p. 27-35. O autor faz todas essas considerações com relação ao próprio conceito de direito, mas suas conclusões são aplicáveis a conceitos jurídicos em geral, como o de doação.

33 A determinação do conceito, por outro lado, só tem relevância na medida em que condicionará a aplicação das regras regulativas próprias ao instituto. Nesse sentido, ENGISCH afirma que "tanto as definições legais como as permissões são, pois, regras não autônomas. Apenas têm sentido em combinação com imperativos que por elas são esclarecidos ou limitados", cf. K. ENGISCH, Introdução ao pensamento jurídico cit., p. 39.

${ }^{34}$ Cf. J. R. L. LOPES, As palavras e a lei cit., pp. 37-38. Uma das críticas feitas à disciplina da doação é justamente o excessivo respeito a uma tradição, cf. I.7.2 infra.

${ }^{35}$ Cf. II.3.
} 


\section{De causa a negócio - a doação no direito romano}

\section{Origem - a Lex Cincia de donis et muneribus}

A doação adquiriu relevância para o direito romano ${ }^{36}$ a partir da lex Cincia de donis et muneribus ${ }^{37}$, na realidade um plebiscito de 204 a. C. que proibia, salvo no caso de personae exceptae (pessoas excetuadas) ${ }^{38}$, as doações que superassem certo modus ${ }^{39}$. Tratava-se de uma lex imperfecta, ou seja, uma lei que vedava a prática de um ato, mas não continha uma sanção, não estabelecia a nulidade do ato nem nenhuma penalidade para a sua prática. Em virtude disso, posteriormente o pretor concederá uma exceptio legis Cinciae ao doador contra a pretensão do donatário à execução da doação ${ }^{40}$.

A principal fonte utilizada para reconstruir o conteúdo da lex Cincia são os Fragmenta Vaticana, um palimpsesto descoberto em 1821 na Biblioteca Vaticana pelo Cardeal Angelo Mai, cujo título correspondente aos fragmentos 260 a 316, e denomina-se Ad legem Cinciam de donationibus ${ }^{41}$. A doutrina entende que a lex Cincia continha, na realidade, duas disposições distintas. A primeira seria a limitação das doações acima de certo valor. A segunda seria uma vedação às doações $o b$ orandam causam, que consistiam na remuneração à atividade dos advogados, que tradicionalmente deveria ser gratuita ${ }^{42}$.

A lei também se referia aos conceitos de dona e munera. O primeiro consistiria nos atos espontâneos, enquanto o segundo correspondia aos donativos devidos em virtude

${ }^{36} \mathrm{O}$ período anterior à lex Cincia caracterizou-se pela ausência de elaboração conceitual relativa à doação, cf. B. BIONDI, Successione testamantaria. Donazioni, in E. AlBERTARIO (org.), Trattato di diritto romano X, Milano, Giuffrè, 1943, p. 633; e B. Biondi, Il concetto di donazione (1947), in Scritti giuridici III - Diritto romano. Diritto privato, Milano, Giuffrè, 1965, p. 651.

${ }^{37}$ Cf. G. LONGO, Lex Cincia de donis et muneribus, in NNDI 9 (1957), pp. 803-04.

${ }^{38} \mathrm{O}$ rol completo das personae exceptae encontra-se em Paul. 71 ad ed., F. V. 298-309, cf. M. TALAMANCA, Istituzioni di diritto romano, Milano, Giuffrè, 1990, p. 774; M. MARRONE, Istituzioni di diritto romano, $3^{\mathrm{a}}$ ed., Palermo, Palumbo, 2006, p. 558.

${ }^{39}$ Não temos, todavia, elementos nas fontes para identificar qual seria esse valor, cf. B. BIONDI, Successione testamentaria. Donazioni cit., p. 639. Segundo TALAMANCA, Istituzioni di diritto romano cit., pp. 747 e 774 , tem-se entendido que tal valor provavelmente correspondia a 1.000 asses (250 sestércios). Embora isso não decorra diretamente das fontes, é de se entender que tal valor coincide com o previsto pela lex Furia testamentaria para os legados, um pouco posterior à lex Cincia.

${ }^{40}$ Note-se, aliás, que somente a partir de Caracala é que advém o princípio morte Cincia removetur, pelo qual a morte do doador torna a doação definitiva e irrevogável para o donatário. Cf. B. BIONDI, Successione testamentaria. Donazioni cit., pp. 639-40.

${ }^{41}$ Cf. A. D'Ors, Estudio preliminar, in A. CATresana Herrero, Fragmentos Vaticanos Edición bilingüe, Madrid, Tecnos, 1988, pp. XI-XII.

${ }^{42}$ Cf. G. G. ARCHI, La donazione - Corso di diritto romano, Milano, Giuffrè, 1960, p. 16. 
de determinadas circunstâncias ${ }^{43}$. Alguns fragmentos do Digesto parecem explicitar essas diferenças ${ }^{44}$. Segundo o primeiro deles, "parece ser doado aquilo que é concedido sem que o direito o imponha" 45 . Segundo outro, "entre donum e munus temos a mesma diferença que entre o gênero e a espécie, pois, como disse Labeão, donum, que vem de "doar", é o gênero, e munus, é a espécie de doação justificada, como a que se faz por ocasião do nascimento ou matrimônio" ${ }^{, 46}$.

Um terceiro fragmento estabelece que “munus é propriamente o que necessariamente devemos fazer em virtude de lei, costume ou império do que tem o poder de mandar" ${ }^{\prime 4}$ e "os dona, porém, são propriamente aquilo que é prestado sem necessidade de direito e espontaneamente; não se efetuando a prestação, não há censura; se a prestação for efetuada, em geral isso é visto com louvor" ${ }^{\text {, }}$.

GAROFALO $^{49}$, em posicionamento aparentemente isolado ${ }^{50}$, entendia que inicialmente a lex Cincia visava apenas à proibição dos munera e somente mais tarde sua aplicação seria estendida aos dona. AsCOLI, todavia, ressaltava que a referência literal a dona e munera indicava a aplicação de suas disposições a ambos, indistintamente ${ }^{51}$.

162.

${ }^{43}$ Cf. P. Giunt, Donazione (storia del diritto romano), in Dig. disc. priv., Sez. civ. 7 (1991), p.

${ }^{44}$ As traduções dos Digesto são livres, foram baseadas em I. L. GARCíA DEL CORRAL, Cuerpo del derecho civil romano I-VI, Barcelona, Molinas, 1889-1898 e A. D’ORS et al., El Digesto de Justiniano IIII, Pamplona, Aranzadi, 1968-1975, e também nos conhecimentos básicos de latim deste autor adquiridos por meio das disciplinas de Introdução ao latim jurídico I e II, ministradas pelo Professor Dárcio Roberto Martins Rodrigues e cursadas em 2005 e 2006, na Faculdade de Direito da Universidade de São Paulo. conceditur".

${ }^{45}$ Cf. Pap. 12 resp. D. 39, 5, 29 pr. = D. 50, 17, 82: "Donari videtur, quod nullo iure cogente

${ }^{46}$ Cf. Ulp. 43 ad ed., D. 50, 16, 194: “Inter 'donum' et 'munus' hoc interest, quod inter genus et speciem: nam genus esse donum Labeo a donando dictum, munus speciem: nam munus esse donum cum causa, ut puta natalicium, nuptalicium".

${ }^{47}$ Cf. Marcian. 1 de iud. pub., D. 50, 16, 214: “"Munus' proprie est, quod necessarie obimus lege more imperiove eius, qui iubendi habet potestatem...".

${ }^{48}$ Cf. Marcian. 1 de iud. pub., D. 50, 16, 214: “...'Dona' autem proprie sunt, quae nulla necessitate iuris officiis et sponte praestantur: quae si non praestentur, nulla repraehensio est et, si praestentur, plerumque laus inest...”.

${ }^{49}$ Cf. F. P. Garofalo, La "lex Cincia de donis et muneribus", in BIDR 15 (1903), p. 310. Tendo-se em vista a data do texto, todavia, é importante fazer a ressalva de que as conclusões do autor podem eventualmente ter sido influenciadas pela diversa metodologia utilizada pela romanística da época. Sobre essas questões, cf. R. Zimmermann, Roman Law, Contemporary Law, European Law, Oxford, Oxford University Press, 2001, especialmente pp. 22-52.

${ }^{50}$ Cf. P. GIUNTI, Donazione (storia del diritto romano) cit., p. 162.

${ }^{51}$ Cf. A. AsCoLI, Sulla legge Cincia, in BIDR 6 (1893), p. 176, sustenta ser possível que "la designazione lex Cincia de donis et muneribus le sia data semplicemente perché nella sua concezione generale, non facendo distinzione alcuna fra dona e munera, li colpisse tutti”. Faz-se, com relação a este texto e em razão da data, a mesma ressalva quanto ao texto de GAROFALO (cf. nt. 49, supra). 
Delineia-se, a partir dessa diferença entre dona e munera, uma distinção que será explorada ao longo deste trabalho, entre as doações praticadas de maneira completamente espontânea e "desinteressada", e aquelas doações na qual há algum interesse ou dever extrajurídico subjacente à prática do ato ${ }^{52}$.

Quanto à finalidade da lex Cincia, podemos identificar três correntes doutrinárias divergentes ${ }^{53}$. Para a primeira, o objetivo da lei seria limitar a liberdade dispositiva a fim de recuperar uma tradicional parcimônia romana, pouco afeita à proliferação dos atos de liberalidade ${ }^{54}$. Para a segunda, a lei buscaria moralizar a comunidade, minando o costume de os governantes obterem amplos donativos em troca da prestação de serviços públicos ${ }^{55}$. Ambas as correntes indicam certa desconfiança com relação à prática da doação, dando a ideia de que a doação é um instituto que merece ser cercado de cautela.

Uma terceira corrente parte da semelhança entre o rol das pessoas excetuadas da vedação imposta pela lex Cincia e o rol de pessoas excetuadas da incidência da lex Iulia et Papia Poppaea, na realidade duas leis aprovadas por Augusto em 18 a.C. e 9 d.C (leis caducárias $)^{56}$, que negaram a capacidade de adquirir por testamento a pessoas não casadas, mas em idade núbil (caelibes), e limitaram a capacidade das pessoas casadas, mas sem filhos $(\text { orbi })^{57}$.

A forma primitiva do testamentum per aes et libram foi a mancipatio familiae, que se tornou usual por escapar às formalidades do testamentum calatis comitiis. A mancipatio familiae consistia em uma espécie de negócio fiduciário através do qual o testador transferia seu patrimônio (familia) por meio das formalidades da mancipatio a um

${ }^{52}$ Cf. III.5.

${ }^{53}$ Cf. P. GIUNTI, Donazione (storia del diritto romano) cit., p. 163.

${ }^{54}$ Cf. B. BIondi, Successione testamentaria. Donazioni cit., p. 636 e M. Talamanca, Istituzioni di diritto romano cit., p. 774.

${ }^{55}$ Cf. F. P. Garofalo, La "lex Cincia de donis et muneribus" cit., p. 311, F. CASAvola, Lex Cincia - Contributo alla storia delle origini della donazione romana, Napoli, Jovene, 1960, p. 18 e G. G. ARCHI, La donazione cit., pp. 21-22. No mesmo sentido, cf. H. M. F. MADEIRA, A advocatio no Direito Romano, Dissertação (Mestrado), São Paulo, Faculdade de Direito da Universidade de São Paulo, 1996, p. 32.

${ }^{56}$ Cf. J. DÉNOYEZ, Les donations visées par la loi Cincia, in IURA 2 (1951), p. 147. 
amicus (familiae emptor), que se encarregava de transferir os bens do testador após sua morte às pessoas por ele indicadas ${ }^{58}$.

Para DÉNOYEZ, a mancipatio familiae seria um tipo de doação, justamente o tipo visado pela lex Cincia, e o objetivo desta teria sido impor pretensos deveres de afeição ao testador com relação a seus parentes mais próximos, protegendo a sucessão destes nos bens do testador ${ }^{59}$. Com a transformação da mancipatio familiae em testamentum per aes et libram, por meio do qual o familiae emptor não mais adquire em vida os bens do testador $^{60}$, a aplicação da lex Cincia teria se tornado impossível, pois o testamentum per aes et libram, por implicar uma efetiva transferência de bens mortis causa, não se encaixaria no conceito de donatio. Como consequência, as leis caducárias teriam sido aprovadas em substituição à lex Cincia, para continuar a garantir os direitos hereditários dos parentes mais próximos do testador ${ }^{61}$. Essa última corrente indica já no direito romano uma aproximação do instituto da doação com o direito das sucessões, uma proximidade cuja importância será acentuada com o advento do Code civil.

\section{A configuração da doação nos períodos do direito romano}

A partir da lex Cincia, tornou-se necessário definir o que deveria ou não ser entendido como donatio, ante a possibilidade de aplicação das proibições contidas na lei aos casos concretos ${ }^{62}$. Algumas expressões contidas na própria lei permitem inferir uma primeira concepção de doação ${ }^{63}$, que teria sido translativa, ou seja, uma doação real consubstanciada na transferência imediata da propriedade de uma coisa a outrem ${ }^{64}$.

${ }^{58}$ Cf. M. MARRONE, Istituzioni di diritto romano cit., pp. 610-11.

${ }^{59}$ Cf J. DÉNOYEZ, Les donations visées par la loi Cincia cit., pp. 147 e 151.

${ }^{60} \mathrm{Cf}$. M. MARRONE, Istituzioni di diritto romano cit., p. 612.

${ }^{61}$ Cf. J. DÉNOYEZ, Les donations visées par la loi Cincia cit., pp. 151-52. Deve-se ressaltar, todavia, que as leis caducárias se inserem no específico contexto histórico de uma política de incremento demográfico levada a cabo por Augusto. Além disso, a querela inofficiosi testamenti, que concedia proteção sucessória aos parentes mais próximos do de cujus, somente se desenvolveu em período bem posterior às lex Cincia, cf. M. MARRone, Istituzioni di diritto romano cit., pp. 576 e 625-26 e M. TALAMANCA, Istituzioni di diritto romano cit., p. 768.

${ }^{62}$ Cf. G. G. ARCHI, Donazione (diritto romano), in ED 13 (1964), pp. 931-2.

${ }^{63}$ Cf. G. G. ARCHI, La donazione cit., p. 10, trata-se das expressões donare capere liceto (Paul. 71 ad ed., F. V. 298), si quis ... accipit duit (Paul. 71 ad ed., F. V. 307) e dare capere lex eis permittat (Paul. 71 ad ed., F. V. 309).

${ }^{64}$ Cf. G. G. ARChI, Donazione (diritto romano) cit., pp. 931; G. G. ARCHI, La donazione cit., p. 10 . 
CASAVOLA defendeu que a doação mais antiga teria consistido na mera disponibilidade, no caso de res nec mancipi, ou atribuição de uma possessio ad usucapionem, no caso de res mancipi $^{65}$. Todavia, a essa tese contrapôs-se TALAMANCA, para quem o reconhecimento de uma doação "possessória" não encontra nenhum respaldo nas fontes ${ }^{66}$.

A jurisprudência do período clássico, por outro lado, passou a conceber a doação como uma causa, que servia à prática dos mais diversos atos jurídicos. A palavra causa era usada pelos juristas romanos com os mais variados significados ${ }^{67}$. No caso da doação, relacionava-se à ideia de negócios abstratos, que são aqueles cujos efeitos negociais se produzem independentemente da sua "razão de ser" 68 .

Isso significa que a causa é externa a esses negócios, não emerge da sua estrutura, de modo que os negócios podem ser concluídos em razão de causas diversas, embora o efeito deles decorrente seja o mesmo. Eram exemplos de negócios abstratos no direito romano a mancipatio, a in iure cessio, a traditio, a stipulatio e a acceptilatio ${ }^{69}$. Nesse sentido, a donatio seria uma das possíveis causas desses negócios abstratos, ou seja, a justificativa de uma aquisição, da assunção de uma obrigação ou do perdão de uma dívida $^{70}$.

A donatio in dando, em princípio, implicava a transferência da propriedade de uma coisa do patrimônio do doador para o do donatário através da mancipatio, da in iure cessio e da traditio. A jurisprudência, todavia, passou a admitir também como modo de realização de doação a constituição de outros direitos reais donationis causa em favor de outrem, mesmo que isso não implicasse efetiva transferência da propriedade de uma coisa $^{71}$.

${ }^{65}$ Cf. F. Casavola, Lex Cincia cit., p. 147.

${ }^{66}$ Cf. M. TAlamanca, Donazione possessoria e donazione traslativa, in BIDR 64 (1961), $\mathrm{p}$.

283.

${ }^{67}$ Cf. G. Grosso, Causa del negozio giuridico (diritto romano), in ED 6 (1960), p. 532. Cf.

II.2.

${ }^{68}$ Cf. B. BIONDI, Le donazioni cit., p. 411-13.

${ }^{69} \mathrm{Cf}$. M. MARRONE, Istituzioni di diritto romano cit., pp. 126 e 157-58. Segundo ARCHI, a tripartição das modalidades de doação em in dando, in obligando e in liberando não é exaustiva, ou seja, não abarca todos os casos, cf. G. G. ARCHI, Donazione (diritto romano) cit., p. 938.

${ }^{70} \mathrm{Cf}$. M. TALAMANCA, Istituzioni di diritto romano cit., pp. 773.

${ }^{71}$ Cf. G. G. ARCHI, Donazione (diritto romano) cit., p. 937. 
Em Pomp. 33 ad Sab., D. 39, 5, 9 pr., por exemplo, lê-se que "parece ser doação o habitar gratuitamente em edifício alheio" ${ }^{72}$. Esse habitare gratis deve ser entendido como a concessão gratuita, causa donationis, de um direito real de habitação ${ }^{73}$. Não se trata de contrato de comodato, pois os contratos reais (mútuo, comodato, depósito, penhor) não entravam na noção de donatio $^{74}$. Embora, segundo MACCORMACK, tais atos e a doação tenham pertencido todos a uma mesma categoria geral em um estágio arcaico do direito romano ${ }^{75}$, a doação nunca foi considerada um contrato gratuito ${ }^{76}$.

A donatio in obligando, por outro lado, era feita mediante recurso à stipulatio, através da qual o doador se obrigava perante o donatário a transferir-lhe determinado bem ${ }^{77}$ a título de doação. A doação obrigatória tinha por objeto uma prestação, e caracterizava-se por uma separação entre a promessa, que era a verdadeira doação, e a transferência do bem, que consistia na execução da promessa ${ }^{78}$.

Por fim, as donationes in liberando se realizavam através da acceptilatio e do pactum de non petendo. A acceptilatio era um antigo modo de extinção ipso iure das obrigações decorrentes de contratos formais, que com o passar do tempo foi-se tornando uma espécie de meio de remissão de dívida ${ }^{79}$. Assim, configurava-se a donatio in

${ }^{72}$ Cf. Pomp. 33 ad Sab., D. 39, 5, 9 pr.: "In aedibus alienis habitare gratis donatio videtur...".

${ }^{73}$ Cf. G. G. ARCHI, La donazione cit., pp. 89-90. Sobre essa discussão, cf. R. ZIMMERMANN, The Law of Obligations - Roman Foundations of the Civilian Tradition, London, Oxford University, 1996, pp. 488-89, nt. 69.

${ }^{74}$ Cf. B. BIONDI, Successione testamentaria. Donazioni cit., p. 43, M. MARRONE, Istituzioni di diritto romano cit., p. 557 e M. TALAMANCA, Istituzioni di diritto romano cit., pp. 773-74.

${ }^{75}$ Cf. G. MACCORMACK, Gift, Debt, Obligation and the Real Contracts, in LABEO 31 (1985), p. 138 .

${ }^{76}$ Cf. II.1.

${ }^{77}$ Segundo ARCHI, os exemplos das fontes normalmente se referem a uma doação realizada através da stipulatio que tem por conteúdo um dare, porém não se pode excluir a possibilidade de doações in obligando em que sejam previstos um fare ou um non fare, cf. G. G. ARCHI, La donazione cit., pp. 95-96 e G. G. ARCHI, Donazione (diritto romano) cit., p. 937.

${ }^{78}$ Como exemplos de fragmentos que tratam da doação in obligando, em Mod. 8 different., D. 39, 5, 22, lê-se: "Eum, qui donationis causa pecuniam vel quid aliud promisit..." (= "Ele que prometeu dinheiro ou outra coisa por causa de doação...”). Em Iav. 14 ex Cass., D. 39, 5, 24, por sua vez, se lê: "Fideiussori eius, qui donationis causa pecuniam supra modum legis promisit..." (= "Ao fiador do que prometeu dinheiro a causa de doação acima do limite da lei...”). Por fim, em Herm. 6 iur. epist., D. 39, 5, 33 pr., lê-se: "Qui id, quod ex causa donationis stipulanti spoponderat" (= "Ele que se obrigou a pagar o que havia prometido ao que estipulou por causa de doação").

${ }^{79}$ Cf. J. C. MoReIRA Alves, Direito romano II - Instituições de direito romano. B - Parte especial: Direito das obrigações. Direito de família. Direito das sucessões, $6^{\mathrm{a}}$ ed., Rio de Janeiro, Forense, 2005, p. 86: "a acceptilatio foi, a princípio, o modo solene de extinção das obrigações verbis contractae... Quando a solutio passou a ser o modo de extinção da obrigação, a acceptilatio se tornou meio de remissão de débito, isto é, ato pelo qual o credor, de acordo com o devedor, renuncia o direito de exigir deste o 
liberando se o doador, gratuitamente, perdoasse dívida do donatário, que era extinta por meio das formalidades da acceptilatio ${ }^{80}$. Já o "pactum de non petendo é o acordo de vontade entre credor e devedor pelo qual aquele se compromete a não exigir deste o cumprimento de uma obrigação" ${ }^{\text {" } 1}$.

O efeito prático da proibição imposta pela lex Cincia deve ser analisado em separado com relação a cada um dos modos de realização. Conforme mencionamos, tratava-se de uma lex imperfecta, que não previa sanção alguma para o seu descumprimento, de maneira que o pretor concedeu ao doador uma exceptio ${ }^{82}$, chamada legis Cinciae, através da qual poderia paralisar a pretensão do donatário à execução da doação.

A doação in dando que se fazia através da traditio não estava sujeita à exceptio legis Cinciae, pois era uma doação real que se exauria, entrava no patrimônio do donatário com a própria tradição, que consistia na entrega da coisa ${ }^{83}$. Já no caso da doação que se fazia através da mancipatio, a exceptio legis Cinciae era aplicável caso as formalidades tivessem sido adequadamente cumpridas, mas o donatário não tivesse ingressado na posse da coisa. Nesse caso, se o donatário ajuizasse uma rei vindicatio em face do doador, este poderia opor a exceção ${ }^{84}$.

cumprimento da obrigação". Cf. G. G. ARCHI, Donazione (diritto romano) cit., p. 938; G. G. ARCHI, La donazione cit., p. 103.

${ }^{80}$ A título de exemplo, em Ulp. 58 ad ed., D. 39, 5, 17 lê-se: "Si in stipulatum iudicatum novationis causa deductum sit et stipulatio donationis causa accepto lata, dicendum est locum liberationem habere" (= "Se por causa de novação se tiver compreendido em uma estipulação o julgado, e por causa de doação se tiver dada por cumprida a estipulação, é preciso dizer que tem lugar a liberação").

${ }^{81}$ Cf. J. C. MOREIRA Alves, Direito romano II cit., p. 104.

${ }^{82}$ A exceptio era um remédio concedido pelo pretor ao réu no processo formular. Trata-se de um dos meios através dos quais o pretor "corrigia" o ius civile (Pap. 2 defin., D. 1, 1, 7, 1), cf. M. MARRONE, Istituzioni di diritto romano cit., pp. 29 e 86; M. TALAMANCA, Istituzioni di diritto romano cit., p. 319. Sobre a legitimidade para valer-se da exceptio legis Cinciae, registra-se uma controvérsia entre Sabinianos e Proculeianos. Enquanto os Sabinianos limitavam a legitimidade para opor a exceptio ao doador, os Proculeianos teriam admitido uma legitimidade mais extensa. Deve ser lido com reserva o fragmento no qual se afirma que os Proculeianos estenderam a legitimidade para qualquer pessoa (Ulp. 26 ad ed., F. V. 266), cf. G. G. ARCHI, Donazione (diritto romano) cit., p. 941, P. GIUNTI, Donazioni (storia del diritto romano) cit., p. 168, A. Ascoli, Sulla legge Cincia cit., p. 215 e B. Biond, Successione testamentaria. Donazioni cit., p. 641.

${ }^{83}$ Posteriormente, foi admitida a exceptio legis Cinciae no caso em que o doador obtivesse a reintegração da posse por meio do interdictum utrubi. Este era um interdito possessório que protegia o possuidor de coisa móvel que a tivesse em seu poder pelo maior tempo dentro de um ano, cf. M. TALAMANCA, Istituzioni di diritto romano cit., p. 497. Caso o donatário reivindicasse a coisa com base na traditio que havia sido feita, o doador poderia opor a exceptio legis Cinciae.

${ }^{84}$ Cf. B. BIONDI, Successione testamentaria. Donazioni cit., p. 642. 
No caso da doação in obligando, o doador assumia através da stipulatio a obrigação de transferir a coisa para o donatário. Caso houvesse inadimplemento da obrigação e o donatário ingressasse com uma actio ex stipulatu para obrigar o doador a entregar a coisa, este poderia eximir-se do cumprimento de sua obrigação por meio da exceptio legis Cinciae. Por fim, com relação à donatio in liberando realizada através da acceptilatio, era incabível a exceptio legis Cinciae, pois o efeito extintivo daquele ato tornava a doação perfecta, definitiva e irrevogável. No caso do pactum de non petendo, por outro lado, na medida em que operava ope exceptionis, tinha lugar uma replicatio legis Cinciae, que tinha os mesmos efeitos da exceptio ${ }^{85}$.

Com base no exposto, pode-se ver que a exceptio legis Cinciae somente era oponível caso a donatio ainda não fosse perfecta $^{86}$. Esta era a doação definitiva, exaurida e irrevogável, em que tinha ocorrido a passagem definitiva da coisa doada para o patrimônio do donatário. Trata-se daquela doação contra a qual o doador não poderia se valer de remédio jurídico algum. A doação também passou a se tornar perfecta com a morte do doador (morte Cincia removetur) ${ }^{87}$.

A concepção clássica da doação, todavia, alterou-se radicalmente no período pós-clássico, a partir de uma constituição do imperador Constantino, de data incerta (a doutrina divide-se entre os anos de 316 e 323), que veio até nós através de três fontes diversas: os Fragmenta Vaticana, o Codex Theodosianus e o Codex justinianeu ${ }^{88}$.

Conforme esclarece VOCI, o texto foi sofrendo reduções sucessivas: aquele contido nos Fragmenta é o mais completo, enquanto o que consta no Codex justinianeu é o mais restrito ${ }^{89}$. Essa constituição imperial operou uma verdadeira ruptura com a concepção de donatio vigente até então. Deixando de lado a discussão sobre se essa constituição aboliu expressamente a lex Cincia (BIONDI ${ }^{90}$ o afirma categoricamente, enquanto

${ }^{85}$ Cf. G. G. ARCHI, Donazione (diritto romano) cit., p. 940-41.

${ }^{86}$ Cf. B. BIONDI, Successione testamentaria. Donazioni cit., p. 640-41.

${ }^{87}$ Cf. M. TAlamancA, Istituzioni di diritto romano cit., pp. 774-75; B. BIONDI, Successione testamentaria. Donazioni cit., pp. 643-45.

${ }^{88}$ Respectivamente, cf. F. V. 249, C. Th. 8, 12, 1 e C. 8, 53, 25. (1987), p. 99.

${ }^{89}$ Cf. P. VocI, Tradizione, donazione e vendita da Costantino a Giustiniano, in IURA 38

${ }^{90}$ Cf. B. BIONDI, Successione testamentaria. Donazioni cit., p. 645-46, que entende ser a constituição imperial de 323, e afirma que a lex Cincia, ainda em vigor até 319 , veio a ser abolida expressamente. 
MeLILlo $^{91}$ supõe a sua vigência ainda ao tempo da compilação do Codex Theodosianus), o ponto mais importante é que, com Constantino, a donatio não é mais uma causa dos mais variados atos jurídicos, mas um negócio jurídico típico sujeito a formalidades específicas. Estas consistiam na forma escrita, na entrega da coisa na presença dos vizinhos (traditio advocatata vicinate) e no registro junto a um ofício público mediante depósito de cópia do documento (insinuatio apud acta) ${ }^{92}$.

A forma, aliás, passou a ser o aspecto central e o âmbito da doação ficou restrito à modalidade in dando, ou seja, à transferência de propriedade ou constituição de outros direitos reais, limitando-se a ampla gama de hipóteses que podiam ser incluídas em seu âmbito no período clássico. Isso não significa, porém, que os outros atos de liberalidade ficassem proibidos, mas apenas que não mais seriam qualificados como doação no sentido técnico ${ }^{93}$.

Com Justiniano, por outro lado, verifica-se um novo alargamento do conceito de doação, que, sem deixar de ser concebida como um negócio específico, passou a ser um "gênero de aquisições" 94 e voltou a abranger aquelas modalidades in obligando 95 . O controle público sobre as doações também foi ligeiramente mitigado: só precisavam ser realizadas por escrito e submetidas à insinuatio apud acta aquelas cujo valor excedesse 500 soldos $^{96}$. A restrição da doação à modalidade in dando, e sua posterior ampliação à modalidade in obligando, já indica uma discussão que será fundamental no direito

${ }^{91}$ Para Melillo, a lex Cincia estava em vigor não somente ao tempo de Constantino, mas também em 438, quanto foi finalizada a compilação do Codex, cf. G. MELILLO, Arnobio e l'ultima vicenda della "lex Cincia", in LABEO 8 (1962), p. 65.

${ }^{92}$ Cf. M. MARrone, Istituzioni di diritto romano cit., p. 560; B. BIONDI, Donazione (diritto romano), in NNDI 6 (1960), p. 229, M. TALAMANCA, Istituzioni di diritto romano cit., pp. 208 (sobre a insinuatio apud acta) e 776.

${ }^{93}$ Cf. B. BIONDI, Successione testamentaria. Donazioni cit., pp. 646-48 e 680-82 e G. G. Archi, Donazione (diritto romano) cit., p. 949.

${ }^{94}$ Cf. Inst. 2, 7 pr.: "Est etiam aliud genus adquisitionis, donatio..." (= "existe também outro gênero de aquisição, a doação...”).

${ }^{95}$ Cf. P. GIUNTI, Donazione (storia del diritto romano) cit., p. 175 e B. BIONDI, Successione testamentaria. Donazioni cit., p. 680.

${ }^{96}$ Cf. R. ZimMERMAnN, The Law of Obligations cit., pp. 494-95; M. TALAMANCA, Istituzioni di diritto romano cit., p. 776. Cf. Inst. 2, 7, 2: “...si maiores ducentorum fuerant solidorum, nostra constitutio et quantitatem usque ad quingentos solidos ampliavit..." (=“...se foram maiores que duzentos soldos, uma constituição nossa ampliou esta quantidade até quinhentos soldos...”). 
moderno: a possibilidade de o doador ser obrigado a doar, seja através de um contrato consensual de doação, seja através de um contrato preliminar de doação ${ }^{97}$.

A concepção justinianeia da doação como gênero de aquisições, embora também considerada um negócio específico, remete à ideia clássica da doação como causa, o indicando que nunca foi definitivamente superada. Além disso, prenuncia observações feitas por autores modernos no sentido de que a doação, embora disciplinada no CC como um contrato específico, assemelha-se a uma categoria geral, concretizada através de diferentes atos jurídicos (ou até fatos, para alguns) ${ }^{98}$.

${ }^{97}$ Cf. I.6.

${ }^{98}$ Como será visto, SAVIGNY, escrevendo com base no direito romano, falará na doação como um instituto de parte geral, cf. I.7.1. 


\section{O "ato" de liberalidade - do direito costumeiro ao Code civil}

\section{A ordonnance de 1731 e a doação segundo Domat e Pothier}

Voltaire teria dito que a França sob o Antigo Regime estava regida por tantos costumes jurídicos diferentes - pela sua conta, cento e quarenta e quatro - que os viajantes "trocavam" de direito com quase tanta frequência quanto trocavam de cavalos em suas viagens ${ }^{99}$. GILISSEN, por sua vez, fala em ao menos seiscentos costumes territoriais diferentes entre os séculos XV e XVI, e sessenta e cinco costumes gerais ao final do Antigo Regime, além de trezentos costumes locais já não muito seguidos ${ }^{100}$.

Isso ocorre porque, a partir dos séculos X e XII, os costumes se tornaram territoriais, de maneira que cada um era aplicável à grande maioria dos habitantes de um território. Assim, havia na França um número muito elevado de "regiões consuetudinárias" diferentes. No âmbito do direito civil, os costumes eram a principal fonte do direito e o monarca absolutista, como forma de eliminar particularidades locais e regionais e acabar com privilégios de certos grupos, buscava a unificação do direito através de legislação. A partir do século $\mathrm{XV}$, como consequência, os costumes passam a ser objeto de redação oficial e homologação pelo monarca, dando origem a leis de origem consuetudinária, denominadas ordonnances ${ }^{101}$.

Paralelamente, o direito romano estudado nas universidades passou a infiltrar como direito subsidiário dos países da Europa ocidental, lentamente nos séculos XIII e XIV, e com mais força a partir dos séculos XV e XVI. Esse processo de recepção ocorreu

${ }^{99}$ Cf. R. HYLAND, Gifts cit., p. 34.

${ }^{100}$ GILISSEN ressalta que a diversidade variava conforme a região da França. Era maior em Paris, ao norte e a leste. A oeste, grandes principados como Anjou, Normadia e Poitou conheceram mais cedo uma unidade consuetudinária, e os pays de droit écrit, em razão do recurso ao direito romano, apresentavam menos diversidade. Por outro lado, o costume de Paris apresentou grande difusão, sendo modelo para reformas do século XVI e servindo como costume subsidiário, cf. J. GILISSEN, Introdução histórica ao direito cit., p. 258 e 281.

${ }^{101}$ Cf. J. GILISSEN, Introdução histórica ao direito cit., pp. 247-48, 251, 254 e 291, a primeira iniciativa mais importante foi tomada pelo rei Carlos VII, que ordenou a redação dos diversos costumes de toda a França através da Ordonnance de Montils-lez-Tours, de 1454, o que acabou sendo feito e revisado somente ao longo do século XVI, principalmente pelo trabalho de Christofle de Thou. Entre os séculos XVI e XVIII, verifica-se a existência de "grandes" ordonnances, promulgadas pelo rei, mas na realidade elaboradas por importantes ministros e chanceleres, que muitas vezes contribuíram para a codificação do direito e coordenação das leis em vigor. Enquanto as do século XVI continham disposições sobre matérias diversas sem classificação ou sistematização, as dos séculos XVII e XVIII, como as de COLBERT (ministro de Luis XIV) e D'AGUESSEAU (ou DAGUESSEAU - chanceler de Luis XV), são consideradas precedentes diretos dos Códigos modernos, pois tinham o objetivo de unificar e codificar o direito francês. 
com mais força no sul da França, nos locais que vieram a ser conhecidos como pays de droit écrit, em oposição aos pays de droit coutumier ${ }^{102}$.

Nesse contexto, D’AgUESSEAU foi responsável pela elaboração de algumas ordonnances que tratavam de certas matérias do direito civil. Uma delas tratava especificamente das doações, e exerceu grande influência sobre os redatores do Code civil $^{103}$. Logo em seu art. $1^{\mathrm{o}}$, a Ordonnance de $1731^{104}$ dispunha que todos os atos que implicassem doação entre vivos deveriam ser feitos perante o notário e permaneceriam registrados, sob pena de nulidade ${ }^{105}$, disposição que foi literalmente incorporada ao Código no art. $931^{106}$.

Note-se que a principal preocupação do direito ao regular as doações parece ter sido a solenidade do ato e a exigência da insinuação, isto é, a descrição do ato no registro público. Tais formalidades, que tinham o objetivo de evitar fraudes e dar publicidade ao

${ }^{102}$ Cf. J. GILISSEN, Introdução histórica ao direito cit., pp. 239-41 e 352-53. A diferença ocorreu porque a realeza francesa teve uma política de retardar a infiltração do direito romano nas regiões em que detinha maior poder, permitindo o desenvolvimento do direito consuetudinário no século XIII. No sul da França, por outro lado, a autoridade do rei foi "praticamente nula" durante o século XII e início do XIII, e, ao reconquistar o poder sobre a região, viu-se obrigado a aceitar a "situação adquirida", com a ressalva de que o direito romano não poderia ser aplicado caso contrariasse os costumes.

${ }^{103}$ Cf. J. GILISSEN, Introdução histórica ao direito cit., pp 264-65, 276-78 e 310-14.

104 Cf. Ordonnance de Louis XV, Roy de France et de Navarre, Donnée à Versailles au mois de Février 1731, Pour fixer la Jurisprudence sur la nature, la forme, les charges ou les conditions des Donations, Paris, L'Imprimerie Royal, 1731, disponível em http://gallica.bnf.fr [acesso em 25 de dezembro de 2012]. O texto também está disponível em F. A. ISAMBERT - A. J. L. JOURDAN, Recueil général des anciennes lois françaises XXI (1 $1^{\text {er }}$ septembre $1715-1^{\text {er }}$ janvier 1797) - Depuis l'an 420 jusqu'à la Révolution de 1789, Paris, Belin-Leprieur, 1830, p. 345, mas, segundo GILISSEN, trata-se de edição "medíocre, feita à pressa", embora "útil para a época moderna", cf Introdução histórica ao direito cit., p. 297, nt. 94.

${ }^{105}$ Art. $1^{\circ}$. Tous actes portant donations entre-vifs, seront passez par-devant notaires, et il en restera minute, à peine de nullité.

Tal disposição, que foi literalmente incorporada ao Code civil (art. 931), repetia o conteúdo do art. 132 da Ordonnance de Villers-Cotterêts de 1539 (outra das grandes ordonnances), atribuída a Poyet, chanceler de Francisco I:

Art. 132. Nous voulons que toutes donations qui seront faites ci-après, par et entre nos sujects, soient insinuées et enregistrées en nos cours et jurisdictions ordinaires des parties, et des choses données, autrement seront reputées nulles, et ne commenceront à avoir leur effect que du jour de ladite insinuation, et ce quant aux donations faites en la présence des donataires et par eux acceptées.

O texto integral da Ordonnance de Villers-Cotterêts de 1539 está disponível em http://www.assemblee-nationale.fr/histoire/villers-cotterets.asp [acesso em 25 de dezembro de 2012]. Cf. também, F. A. ISAMBERT - A. J. L. JOURDAN, Recueil général des anciennes lois françaises XII (1514-1546) - Depuis l'an 420 jusqu'à la Révolution de 1789, Paris, Belin-Leprieur, 1828, p. 627.

${ }^{106}$ Cf. J. GILISSEN, Introdução histórica ao direito cit., p. 311. 
ato, sujeitavam todas as doações, com duas exceções envolvendo apenas bens móveis (valor não excedente a mil libras e ocorrência da tradição real) ${ }^{107}$.

Para ZIMMERMANN, através dessas formalidades buscava o governo central do Antigo Regime evitar que a riqueza das famílias dominantes se dissipasse ${ }^{108}$, desencorajando determinados tipos de transações, notadamente meios de transferência a título gratuito que se ligavam, ainda que com diferenças, ao modelo das doações mortis causa $^{109}$.

Estas, no direito romano, eram atribuições de uma coisa a outrem (com transferência da propriedade) por alguém que se encontrava em perigo de vida. Caso o doador sobrevivesse ao perigo, tinha direito à devolução da coisa. Também eram doações mortis causa as doações reais em que, prescindindo do perigo de vida, estipulava-se a devolução da coisa ao doador caso sobrevivesse ao donatário. A lógica era preferir-se o doador ao donatário e o donatário aos seus herdeiros ${ }^{110}$.

Note-se, porém, que o art. $1^{\circ}$ da Ordonnance de 1731 não continha uma definição de doação, conforme apontou PoRTALIS na reunião do Conselho de Estado que deliberou sobre o art. 894 do Code civil, e tampouco a qualificava explicitamente como contrato. Foi com base nas obras de DOMAT e, principalmente, POTHIER, que os redatores do CC fr. colheram a noção de doação que iria influenciar o seu trabalho. DOMAT, ao buscar construir de maneira racional e lógica as regras jurídicas que deveriam reger a França, exerceu grande influência sobre os juristas do século XVIII ${ }^{111}$. POTHIER, por sua

${ }^{107}$ Cf. R. POTHIER, Traité des donations entre-vifs, in Oeuvres complètes de Pothier XXIIINouvelle édition - Traités des donations entre-vifs, des personnes et des choses, Paris, Thomine et Fortic, 1821, pp. 36-37, 61, 68-69, 74-75 e 87-89.

${ }^{108}$ Cf. R. ZIMMERMANN, The Law of Obligations cit., pp. 500-01 e J. P. DAwSON, Gifts and Promises - Continental and American Law Compared, New Haven, Yale University Press, 1980, pp. 118-19.

${ }^{109}$ Cf. G. AMENTA, La donazione e la sua struttura contrattuale, Torino, Giappichelli, 2002, pp. 34-36.

${ }^{110}$ Cf. M. TALAMANCA, Istituzioni di diritto romano cit., p. 778 e M. MARRONE, Istituzioni di diritto romano cit., pp. 563-64. Devido ao fato de o resultado prático da doação mortis causa (aquisição a título particular) ser muito parecido com o do legado, com o passar do tempo a disciplina jurídica do segundo foi sendo estendida à primeira. Justiniano chegou a proclamar a equiparação entre os dois institutos. Todavia, a equiparação é errônea, a começar pela estrutura. Embora os institutos se assemelhem, diferentemente da instituição do legatário, a doação mortis causa é bilateral, pois dela participam tanto o doador quanto o donatário.

${ }^{111}$ É tido como o "restaurador da razão" na ciência do direito, cf. H. CAPITANT, De la cause des obligations - Contrats, engagements unilatéraux, legs, $3^{\mathrm{a}}$ ed., Paris, Dalloz, 1927, p. 164. 
vez, é considerado o "pai espiritual” do Code civil, uma vez que suas obras eram leitura cotidiana dos redatores e numerosos textos seus foram transformados em artigos de lei ${ }^{112}$.

Para DOMAT, não havia dúvida de que a doação era um contrato por consentimento recíproco entre o doador e donatário, por meio do qual aquele transmitia gratuitamente uma coisa a este, que a aceitava e a adquiria ${ }^{113}$. Para POTHIER, por outro lado, doação era uma convenção através da qual uma pessoa, por liberalidade, abdicava irrevogavelmente de alguma coisa em benefício de outra pessoa, que a aceitava ${ }^{114}$.

Embora a definição de ambos seja ligeiramente diversa, não parece haver divergência substancial entre ambas as concepções. POTHIER ressaltava bastante a estrutura contratual, afirmando que a aceitação constituía sua essência mesma, pois era uma convenção entre doador e donatário e, portanto, exigia o consentimento de ambas as partes $^{115}$. Curiosamente, a doação não era incluída entre os contrats de bienfaisance (mútuo, comodato, depósito e mandato) - aqueles que se celebram em razão da utilidade para apenas uma das partes contratantes -, mas entre os contratos que estavam sujeitos a determinadas regras ou determinada forma, ao lado do matrimônio, da constituição de renda e - curiosamente - da letra de câmbio ${ }^{116}$.

Embora seja impossível estabelecer uma relação direta, não deixa de ser sintomático que uma concepção moderna de doação veja na forma o seu elemento essencial, fazendo com que se aproxime bastante dos negócios abstratos (como os títulos de crédito $)^{117}$. Além disso, a unilateralidade da letra de câmbio não é de todo estranha à ideia de que a doação exprime uma operação econômica unilateral ${ }^{118}$. Estamos, porém, no campo da mera especulação.

As outras características fundamentais da doação apontadas por DOMAT e POTHIER são a imediatidade e a irrevogabilidade da disposição da coisa, traduzidas na máxima donner et retenir ne vaut. Essas características, que não foram herança do direito

${ }^{112}$ Cf. J. GILISSEN, Introdução histórica ao direito cit., pp. 355-56 e 365-66.

${ }^{113}$ Cf. J. Domat, Les lois civiles dans leur ordre naturel, in J. REMY (org.), Oeuvres complètes de J. Domat I - Nouvelle édition, Paris, Firmin Didot, 1828, p. 301.

${ }^{114}$ Cf. R. POTHIER, Traité des donations entre-vifs cit., p. 1.

${ }^{115}$ Cf. R. POTHIER, Traité des donations entre-vifs cit., pp. 37 e 89.

${ }^{116}$ Cf. R. PothIER, Traité des obligations, in Oeuvres complètes de Pothier I - Nouvelle édition - Traité des obligations, Paris, Thomine et Fortic, 1821, pp. 19-20.

${ }^{117}$ Cf. III.4.2.

${ }^{118}$ Cf. I.7.1. 
romano, eram consideradas fundamentais para se diferenciar a doação entre vivos da doação mortis causa, na qual havia liberdade de o doador dispor da coisa doada até a sua morte, inclusive tendo o direito de direito de privar o donatário da coisa ${ }^{119}$.

Segundo BIONDI, a regra teve origem em uma interpretação equivocada de uma constituição de Teodósio, de $415^{120}$. Esta, na realidade, simplesmente estabelecia que a reserva de usufruto - admitida expressamente por outra constituição, de $417^{121}$ - não poderia ser considerada traditio para o aperfeiçoamento da doação. Não trazia, portanto, a ideia de que o doador devia se desfazer imediatamente da coisa, princípio que deriva exclusivamente da tradição francesa e tem consequências jurídicas importantes, pois, da maneira como foi desenvolvido pela doutrina, implica a limitação da doação a um ato translativo de direitos sobre a coisa, excluindo a possibilidade da doação com efeitos obrigatórios $^{122}$. Como consequência, o âmbito da doação ficou limitado em relação ao direito romano clássico e justinianeu, abrangendo somente a modalidade in dando.

\section{Caracterização da doação no Code civil}

A ideia da codificação foi afirmada desde o início na Revolução Francesa, e, em matéria civil, diversos projetos foram redigidos por comissões presididas por CAMBACÉRÈS. Com o consulado de Napoleão, criou-se uma comissão de quatro membros - Tronchet, Maleville, Bigot-Préameneu e Portalis - que apresentou o projeto do novo Código. Enquanto Tronchet e Bigot-PrémeAneu eram mais influenciados pelo direito dos pays de droit coutumier, PORTALIS e MALEVILLE o eram pelos pays de droit écrit. PORTALIS teve o papel mais importante na comissão ${ }^{123}$. Segundo GILISSEN, embora teoricamente tenha havido uma "transação" entre as duas influências, o direito costumeiro parece ter prevalecido (apesar da orientação de PORTALIS) ${ }^{124}$.

${ }^{119}$ Cf. J. DOMAT, Les lois civiles dans leur ordre naturel cit., p. 298 e R. POTHIER, Traité des donations entre-vifs cit., pp. 55-56.

${ }^{120}$ Cf. C. Th. $8,12,8$ pr.

${ }^{121}$ Cf. C. Th. 8, 12, 9 .

${ }^{122} \mathrm{Cf}$. B. BIONDI, Le donazioni cit., pp. 61-63.

${ }^{123}$ Cf. N. BobBIO, Il positivismo giuridico - Lezioni di Filosofia del diritto raccolte dal dott. Nello Morra, reimpr., Torino, Giappichelli, 1996, p. 64.

${ }^{124}$ Cf. J. GILISSEN, Introdução histórica ao direito cit., pp. 450-54. 
Após ter sido completamente proibida durante o período revolucionário ${ }^{125}$, a doação passou a ser disciplinada pelo CC fr. Não foi disciplinada junto às modalidades contratuais, mas ao lado do testamento no Título II do Livro III, denominado originalmente "Des donations entre vifs et des testaments". Assim, a doutrina construída com base no Código passou a estudar a doação e o testamento lado a lado, vistos como duas modalidades de transferências gratuitas de propriedade e denominadas genericamente de atos de liberalidade ${ }^{126}$.

Recentemente, a Lei 2006-728, de 23 de junho de 2006, alterou a denominação do Título II para "Des libéralités”, consagrando a construção doutrinária. A partir de 2006, a liberalidade foi definida no art. 893 como "o ato através do qual uma pessoa dispõe a título gratuito do todo ou de parte de seus bens ou de seus direitos em benefício de outra pessoa". Em seguida, dispõe que a liberalidade somente pode ser feita através de doação entre vivos ou de testamento ${ }^{127}$.

É importante mencionar que a Lei 2006-728 teve origem em uma iniciativa de CARbONNIER - em conjunto com CATAla, SAINT AfFrique e Morin - que "ofereceu" uma proposta de reforma da disciplina das liberalidades no Code civil. Trata-se, como esclareceu o próprio CARBONNIER, de uma obra privada, produzida por uma equipe privada. A proposta, entre muitos outros aspectos, buscou reforçar a ideia de que existe uma noção unitária de liberalidade, que transcende a dualidade presente na redação original do Code civil entre doação e testamento, pois ambas as figuras acarretam aquisições sem contrapartida. Para o jurista, a liberalidade, conforme a etimologia, indicaria liberdade, tanto uma liberdade de disposição do proprietário, quanto uma liberdade psicológica, afetiva, no plano dos sentimentos. É uma liberdade, entretanto, que

${ }^{125}$ Cf. R. HYLAND, Gifts cit., pp. 1 e 4.

${ }^{126}$ Cf., por todos, R. HYLAND, Gifts cit., p. 586.

${ }^{127}$ Art. 893. La libéralité est l'acte par lequel une personne dispose à titre gratuit de tout ou partie de ses biens ou de ses droits au profit d'une autre personne. Il ne peut être fait de libéralité que par donation entre vifs ou par testament.

A limitação às doações entre vivos e ao testamento visa à tradicional vedação das doações mortis causa, que, contudo, já foi em certa medida atenuada, cf. Ph. MALAURIE, Les successions - Les libéralités, in Ph. MALAurie - L. AYNÈS, Droit civil, $4^{\mathrm{a}}$ ed., Paris, Defrénois, 2010, pp. 143-44 e nt. 2. Até 2006, o dispositivo tinha a seguinte redação:

Art. 892. On ne pourra disposer de ses biens, à titre gratuit, que par donation entre vifs ou par testament, dans les formes ci-après établies. 
não pode ser absoluta, sob pena de prejudicar a igualdade, principalmente entre os herdeiros ${ }^{128}$.

Essa afirmação fornece um indício da razão da disciplina da doação em conjunto com o testamento, que parece ser o extremo cuidado com o qual o direito francês trata da proteção dos herdeiros necessários. O art. 931, conforme já mencionado, traz as mesmas exigências formais do art. $1^{\circ}$ da Ordonnance de 1731, isto é, determina a realização da doação perante o notário e exige o registro sob pena de nulidade ${ }^{129}$.

Para ZIMMERMANN e DAWSON, tal exigência, posterior à Revolução Francesa, obviamente não tinha mais o propósito de proteger o patrimônio da aristocracia contra a dispersão, mas sua manutenção foi tida como conveniente para proteger os herdeiros necessários, garantindo-lhes uma distribuição equitativa da herança e evitando que fossem prejudicados com doações realizadas a terceiros ${ }^{130}$.

Para a proteção dos herdeiros necessários, o Code civil adotou uma quota disponível variável conforme o número de descendentes (art. 913). Criou, assim, um sistema novo, que mesclou elementos dos três diferentes sistemas que regularam os direitos sucessórios antes do Code civil: o dos pays de droit écrit, o dos pays de droit coutumier e o revolucionário ${ }^{131}$. O formalismo imposto à doação inseria-se na ideia de

${ }^{128}$ Cf. J. CARbonnier, Préface, in J. CARBonnier et al., Des libéralités - Une offre de loi, Paris, Défrenois, 2003, p. 5.

${ }^{129}$ Art. 931. Tous actes portant donation entre vifs seront passés devant notaires, dans la forme ordinaire des contrats ; et il en restera minute, sous peine de nullité.

${ }^{130}$ Cf. R. ZimMERMANN, The Law of Obligations cit., pp. 500-01 e J. P. DAwson, Gifts and Promises cit., pp. 118-19. Ressalta CARBONNIER que a Revolução havia percebido claramente a capacidade aristocrática e contrarrevolucionária das liberalidades, atentatória da igualdade dos herdeiros, cf. J. CARbonnier, Préface, in J. CARBOnNIER et al., Des libéralités cit., pp. 8-9.

${ }^{131} \mathrm{O}$ primeiro é inspirado no direito romano, no qual a sucessão testamentária é a regra. Reconhece-se a proteção da sucessão dos parentes próximos com base em um dever familiar do de cujus através da querela inofficiosi testamenti e prevalece a limitação da quarta Falcídia. Segundo MOREIRA ALVES, a querela inofficiosi testamenti era expediente utilizado para atacar testamento no qual o de cujus houvesse deserdado, sem motivo ponderável, certos parentes próximos. Já a Lex Falcidia estabelecia que "o testador somente podia dispor, para legados, de três quartos da herança, cabendo a quarta parte restante (a chamada quarta Falcidia) ao herdeiro testamentário", cf. J. C. MOREIRA ALVES, Direito romano II cit., pp. 418-19 e 470, respectivamente. O segundo sistema, do droit coutumier, atribui uma importância menor ao testamento e tem como objetivo a conservação dos bens dentro da família. O costume de Paris estabeleceu a regra da reserva indisponível de quatro quintos (réserve des quatre-quints), e foi seguido por grande parte dos países de direito consuetudinário. Por fim, o sistema revolucionário era notoriamente hostil à liberdade testamentária e objetivava dividir as grandes fortunas, estabelecendo a igualdade das quotas hereditárias. Tal sistema contrariava o anterior, que, ao buscar evitar a dissipação do patrimônio, gerava a concentração da maior parte da herança no filho primogênito - no caso dos nobres - ou naquele escolhido pelo de cujus. 
cercar de cautela um ato cuja prática poderia acarretar a dissipação do patrimônio do de cujus e consequente lesão ao direito dos herdeiros necessários. Tão logo o formalismo foi imposto no CC, todavia, passou a ser relativizado pela doutrina e pela jurisprudência, em um processo que se usa chamar de "dessolenização das liberalidades" (désolemnisation des libéralités), que será tratado adiante ${ }^{132}$.

Com relação à definição de doação, após alguma discussão na reunião do Conselho de Estado que apreciou a matéria ${ }^{133}$ decidiu-se pela sua inclusão. Foi consagrada no art. 894 do Code civil, que tem uma redação nitidamente inspirada pelo direito costumeiro: "La donation entre vifs est un acte par lequel le donateur se dépoille actuellement et irrévocablement de la chose donnée en faveur du donataire qui l'accepte".

Chama atenção a definição como "ato" e não como contrato, o que contraria a concepção contratual de DOMAT e PoTHIER. Deve-se a um curioso episódio. Napoleão, na época ainda Primeiro Cônsul, presidiu pessoalmente muitas das sessões do Conselho de Estado que deliberaram sobre o projeto ${ }^{134}$. No caso da doação, inicialmente definida como "contrato", o futuro imperador afirmou que a noção não seria aplicável, pois contrato impõe obrigações recíprocas aos contratantes ${ }^{135}$. Em atenção à observação, MALEVILLE propôs a substituição da expressão "contrat" por "acte", que permanece no Código até hoje $^{136}$.

Sobre o ocorrido, Planiol faz duras observações. Segundo ele, Napoleão não compreendia a categoria dos contratos unilaterais, e os conselheiros de Estado tiveram a fraqueza de ceder à observação desajeitada de seu mestre, observação que não provava

Sobre esses aspectos, cf. Ph. MALAURIE, Les successions - Les libéralités cit., pp. 309-11 e R. HYLAND, Gifts cit., p. 1.

${ }^{132}$ Cf. II.5.1.

${ }^{133}$ Cf. I.1.

${ }^{134}$ CF. J. GILISSEN, Introdução histórica ao direito cit., p. 452.

${ }^{135} \mathrm{Cf}$. P. A. FENET, Recueil complet des travaux préparatoires du code civil XII cit. p. 261: "Le Premier Consul dit que le contrat impose des charges mutuelle aux deux contractans ; qu'ainsi cette expression ne peut convenir à la donation".

${ }^{136}$ Cf. P. A. FENET, Recueil complet des travaux préparatoires du code civil XII cit. p. 262-63: "M. Maleville dit que, si l'on juge les définitions nécessaires, on pourrait définir la donation, un acte par lequel le donateur se pépouille actuellement et irrévocablement d'une chose, en faveur du donateur qui l'accepte", de modo que "L'article est adopté avec la substitution du mot acte au mot contrat". 
outra coisa que não a sua ignorância em matéria de direito ${ }^{137}$. TROPLONG, um dos "grandes comentadores" do Code civil da chamada Escola da Exegese ${ }^{138}$, igualmente criticara o episódio anos antes, afirmando que, ao invés de os conselheiros se preocuparem em examinar melhor o mérito da proposta, eles simplesmente se entregaram a uma imprevista digressão sobre a utilidade ou não de colocar definições nos códigos, em meio à qual MALEVILle fez passar sem discussão uma emenda atendendo aos caprichos do Primeiro Cônsul ${ }^{139}$.

O episódio seria considerado apenas uma curiosidade histórica, não tivesse influenciado o surgimento de concepções não contratuais, notadamente na Itália, onde o art. 1.050 do $\mathrm{CC}$ de 1865 repetiu literalmente a regra do $\mathrm{CC} \mathrm{fr}^{140}$. Na França, porém, nem mesmo os chamados "grandes comentadores" da Escola da Exegese negaram a estrutura contratual $^{141}$, não sendo também questionada por PLANIOL ${ }^{142}$ e muito menos pelos autores modernos ${ }^{143}$. A própria exigência de aceitação que consta no art. $932^{144}$ indicaria a contratualidade da doação no sistema do Code civil.

$\mathrm{O}$ art. 894 do Code, além disso, manteve a regra donner et retenir ne vaut, reafirmando a necessidade de a disposição da coisa ser atual e irrevogável. O requisito da atualidade, entretanto, ganhou novo contorno com a adoção do princípio do consenso translativo ou translação imediata.

${ }^{137}$ Cf. M. F. PLANIOL, Traité élémentaire de droit civil conforme au programme officiel des facultés de droit III - Régimes matrimoniaux. Successions. Donations et testaments, $7^{\mathrm{a}}$ ed., Paris, LGDJ, 1918, p. 597.

${ }^{138}$ Cf. J. GILISSEN, Introdução histórica ao direito cit., p. 516.

${ }^{139}$ Cf. R. T. Troplong, Des donations entre-vifs et des testaments I in Droit civil expliquéCommentaire du Titre II du Livre III du Code Napoléon, $2^{\mathrm{a}}$ ed., Paris, Administration du Journal des Notaires et des Avocats, 1862, p. 76. Sobre a discussão acerca da inclusão ou não de uma definição de doação, cf. I.1.

${ }^{140}$ Cf. I.4.1.

${ }^{141}$ Cf. C. Aubry - C. RAU, Cours de droit civil français d'après la méthode de Zachariae VII, $4^{\mathrm{a}}$ ed., Paris, Maison Cosse, 1847, pp. 7-8, R. T. TROPLONG, Des donations entre-vifs et des testaments I cit., p. 77 e G. BAUDRY-LACANTINERIE E A. COLIN, Traité théorique et pratique de droit civil X-I - Des donations entre vifs et des testaments, Paris, Sirey, 1905, pp. 5-6.

${ }^{142}$ Cf. M. F. Planiol, Traité élémentaire de droit civil III cit., p. 597.

${ }^{143} \mathrm{Cf}$., por todos, Ph. MALAURIE, Les successions - Les libéralités cit., p. 144, N. PeterkA, Les dons manuels, Paris, LGDJ, 2001, p. 23, e P. RAYNAUD, Les successions et les libéralités, in G. MARTYP. RAYNAUD, Droit civil, Paris, Sirey, 1983, p. 260.

${ }^{144}$ Art. 932. La donation entre vifs n'engagera le donateur, et ne produira aucun effet, que du jour qu'elle aura été acceptée en termes exprès. L'acceptation pourra être faite du vivant du donateur par un acte postérieur et authentique, dont il restera minute ; mais alors la donation n'aura d'effet, à l'égard du donateur, que du jour où l'acte qui constatera cette acceptation lui aura été notifié. 
Ao dispor que a doação "será perfeita pelo simples consentimento das partes" e que a propriedade dos objetos doados será transferida para o donatário sem necessidade de tradição, o art. $938^{145}$ consagra a separação entre o momento da transmissão do direito sobre a coisa e o momento da transferência de sua posse. Como na compra e venda, a automática transmissão da propriedade do bem faz surgir para o doador uma obligation de délivrance, isto é, de transmissão posterior da posse. O que é vedada é a doação de bens que não integram o patrimônio do doador, conforme dispõe expressamente o art. 943 - a nulidade da doação de "bens futuros" 146 .

Segundo MALAURIE, devem ser entendidos como bens futuros aqueles que não estão ainda sob a propriedade do doador, mas cuja aquisição este se propõe a efetuar. É uma doação de coisa alheia, pois o doador tem a mera expectativa de aquisição do bem, o que atenta contra a irrevogabilidade da doação por submetê-la ao arbítrio do doador ${ }^{147}$. Assim, embora seja possível a postergação do momento de transferência da posse do bem, a disciplina do Code civil exclui totalmente a ideia de uma doação com efeitos meramente obrigatórios, ou seja, aquela em que o doador se obriga em face do donatário a transmitir futuramente a titularidade do bem doado ${ }^{148}$.

\footnotetext{
${ }^{145}$ Art. 938. La donation dûment acceptée sera parfaite par le seul consentement des parties ; et la propriété des objets donnés sera transférée au donataire, sans qu'il soit besoin d'autre tradition.

${ }^{146}$ Art. 943. La donation entre vifs ne pourra comprendre que les biens présents du donateur ; si elle comprend des biens à venir, elle sera nulle à cet égard.

${ }^{147} \mathrm{Cf}$. Ph. MALAURIE, Les successions - Les libéralités cit., pp. 231-32.

${ }^{148}$ Cf. G. AMENTA, La donazione e la sua struttura contrattuale cit., pp. 47-51.
} 


\section{O ponto de transição ou contrato sui generis - a doação no CC italiano}

\section{Ainda sob influência francesa - o Código Civil de 1865}

O primeiro CC do Reino da Itália ${ }^{149}$, de 1865, sofreu "influência direta" e foi, segundo WIEACKER, "essencialmente copiado do Code civil, com cuja moldura jurídica e política se aparentava expressamente a Itália unificada". Apesar disso, “a florescente civilística italiana juntamente com a pandectística alemã inclinava-se muitas vezes para uma interpretação e um desenvolvimento histórico-romanístico que ultrapassavam cada vez mais o tipo francês no sentido da orientação típica da pandectística"150.

Um reflexo dessa perspectiva se dá na disciplina da doação. Esta foi inserida no livro que tratava dos modos de adquirir e transferir a propriedade e outros direitos sobre a coisa (Livro III - "Dei modi di acquistare e di trasmettere la proprietà e gli altri diritti sulle cose"), mas, diferentemente da orientação do Code civil, em um título próprio. O Título III - "Delle donazioni”, estava localizado entre o título que tratava das sucessões (Título II - "Delle successioni") e o que disciplinava as obrigações e os contratos (Título IV - "Delle obbligazioni e dei contratti in genere"), o que parecia explicitar a fisionomia ambígua da doação ${ }^{151}$.

A Exposição de Motivos ao Livro III, de PISANELLI, justificava tal opção, afirmando que a disciplina das doações é conexa tanto à do direito das sucessões quanto à dos contratos. A adoção de um título separado colocado entre uma área e outra do direito civil indicaria que a doação seria uma ponte ou ponto de transição entre essas matérias ${ }^{152}$.

149 Antes da unificação, diferentes regiões da península itálica tiveram suas próprias codificações civis. Para uma análise da disciplina jurídica da doação nesses códigos, cf. G. AMENTA, La donazione e la sua struttura contrattuale cit., pp. 69-71.

${ }^{150}$ Cf. F. WIEACKER, Privatrechtsgeschichte der Neuzeit unter Besonderer Berücksichtigung der Deutschen Entwicklung, 2a ed., Göttingen, Vandenhoeck \& Ruprecht, 1967, trad. port. A. M. B. Hespanha, História do direito privado moderno, $4^{\mathrm{a}}$ ed., Lisboa, Fundação Calouste Gulbenkian, 2010, pp. 394-95 e 576-77. IRTI fala em uma dissonância entre a doutrina civilista e o CC de 1865 , cf. N. IRTI, $L a$ scienza italiana del diritto alla vigilia del BGB, in Riv. trim. dir. pub. (1997), p. 347, disponível em http://www.direitocontemporaneo.com/wp-content/uploads/2014/02/IRTI-Scienza-Italiana-e-BGB.pdf [acesso em 11 de setembro de 2015].

${ }^{151}$ Cf. G. AMENTA, La donazione e la sua struttura contrattuale cit., pp. 71-72 e G. B. FERRI, Dall'intento liberale al cosidetto impegno etico e superetico, in Dall'economia della bontà all'economia del dolore - Saggi di diritto civile, 2a ed., Padova, Cedam, 2005, p. 19.

${ }^{152}$ Cf. G. PISANELl, Relazione del Ministro sul terzo libro del progetto, in Raccolta dei lavori preparatori del codice civile del Regno d'Italia I, Palermo-Napoli, Pedone Lauriel, 1866, p. 90. 
A definição de doação, que está no art. $1.050^{153}$, é praticamente uma tradução para o italiano do art. $894^{154}$ do Code civil. O instituto vem conceituado como "um ato de espontânea liberalidade através do qual o doador se desfaz atualmente e irrevogavelmente da coisa doada em favor do donatário que a aceita". Há duas diferenças. A primeira é a referência à doação "entre vivos", que constava da definição francesa e foi retirada. A segunda é a sua caracterização expressa como um ato de "espontânea liberalidade", que nos remete à exigência do animus donandi.

Não se deve, contudo, dar importância excessiva a essas alterações. A primeira referência era desnecessária, pois se extraía da própria disciplina legal que era da doação inter vivos que se tratava, e não da mortis causa. A segunda tampouco altera o sentido da definição, pois embora não conste expressamente do $\mathrm{CC}$ fr., a doutrina daquele país já considerava o animus donandi - e o considera até hoje - necessário para a configuração da doação ${ }^{155}$.

Chama atenção, por outro lado, a manutenção da definição da doação como "ato", e não como contrato, o que, como vimos, na França foi fruto de um equívoco de Napoleão. Ao contrário daquele país, porém, em que os grandes comentadores desde cedo reafirmaram a estrutura contratual, na Itália a definição legal gerou alguma discussão quanto à natureza jurídica do instituto.

PEROZzi é comumente citado como o mais relevante opositor à natureza contratual. A doação seria um ato unilateral consistente em produzir intencionalmente um aumento do patrimônio do donatário, com a diminuição do patrimônio do doador. A aceitação pelo donatário não seria uma expressão de um querer, mas de um simples sentimento ${ }^{156}$. A posição, todavia, não prevaleceu, como se vê a partir da definição expressa da doação como contrato que consta no CC de 1942, mesmo porque havia muitos

${ }^{153}$ Art. 1.050. La donazione è un atto di spontanea liberalità, col quale il donante si spoglia attualmente ed irrevocabilmente della cosa donata in favore del donatario che l'accetta.

${ }^{154}$ A título de recordação:

Art. 894. La donation entre vifs est un acte par lequel le donateur se dépouille actuellement et irrévocablement de la chose donnée en faveur du donataire qui l'accepte.

${ }^{155}$ Cf. III.3.1.

${ }^{156}$ Cf. S. PEROZZI, Intorno alla donazione, in Archivio giuridico 58 (1897), apud S. PICCININI, Profili della donazione dal codice 1865 ad oggi, in Riv. dir. civ. 38 (1992), pp. 175-76 (não tivemos acesso ao artigo de PEROZZI, mas nos valemos das citações literais do autor que constam no texto de PICCININI). 
dispositivos no Código revogado que faziam menção à aceitação, dando embasamento legal à tese contratualista ${ }^{157}$.

Outra discussão relevante diz respeito à abrangência do conteúdo da doação. Na França, como vimos, era admitida somente a modalidade in dando, que se operava com transferência imediata do bem doado ao donatário. Na Itália, embora o CC de 1865 contivesse os mesmos requisitos da atualidade e irrevogabilidade da doação, estes foram logo abandonados pela doutrina, pois considerados uma herança fora de lugar do direito francês e sua preocupação em diferenciar a doação inter vivos da doação mortis causa ${ }^{158}$.

Além disso, embora do CC 1865 constasse a mesma proibição da doação de bens futuros do CC fr. ${ }^{159}$, a doutrina começou a desenvolver a possibilidade da doação com efeitos obrigatórios e também liberatórios ${ }^{160}$. Não chegaria, porém, ao ponto de admitir uma doação cujo conteúdo consista na realização de prestações de fazer e não fazer, como vem fazendo parte relevante da doutrina atual ${ }^{161}$.

Por fim, o Código de 1865 manteve a exigência de forma solene para a doação que constava do Code civil. O art. 1.056 assim previa: "Tutti gli atti di donazione debbono essere fatti per atto pubblico, altrimenti sono nulli”. A Exposição de Motivos destaca que esse dispositivo, na realidade, atenuou as exigências formais que constavam em Códigos Civis italianos anteriores à unificação. Nesses, além da forma solene, era necessária a aprovação pelo "pubblico ufficiale"

\section{Um novo conceito de doação - o Código Civil de 1942}

O CC de 1942, elaborado em um conturbado período da história italiana e mundial, foi absolutamente inovador em inúmeros aspectos, não só do direito civil, mas do

\footnotetext{
${ }^{157}$ CONTE menciona os arts. 1.050, 1.057, 1.059, 1.060, 1.061, 1.062, 1.063 e 1.070, G. CONTE, Il contratto di donazione tra liberalità e gratuità cit., pp. 9-10.

${ }^{158}$ Cf. G. CONTE, Il contratto di donazione tra liberalità e gratuità cit., pp. 9-10.

159 Art. 1.064. La donazione non può comprendere che i beni presenti del donante; se comprende beni futuri, è nulla riguardo a questi.

${ }^{160}$ Cf. S. PICCININI, Profili della donazione dal codice 1865 ad oggi cit., pp. 173-74, A. Ascoli, Trattato delle donazioni, 2a ed., Milano, Libraria, 1935, pp. 7 e 162 e G. BALBI, Saggio sulla donazione, Torino, Istituto giuridico della R. Università, 1942, pp. 7, 112, 118 e 120-21.

${ }_{161}$ Cf. G. CONTE, Il contratto di donazione tra liberalità e gratuità cit., pp. 37-38.

${ }^{162}$ Cf. G. PISANELli, Relazione del Ministro sul terzo libro del progetto cit., pp. 90-91.
} 
direito como um todo. Podemos destacar, entre tantos outros pontos relevantes, a unificação do direito civil e do direito comercial em um mesmo corpo legislativo, a inclusão da disciplina do direito do trabalho no $\mathrm{CC}$ e uma importante concepção de liberdade contratual fundada na ideia de interesses merecedores de tutela segundo o ordenamento jurídico (art. 1.322, 2) ${ }^{163}$.

Esse caráter inovador não seria diferente em relação à doação, cujo conceito legal afastou-se, definitivamente, da orientação do art. 894 do Code civil. O conceito foi se alterando ao longo do processo de elaboração do novo Código. Inicialmente, foram redigidos, como resultado do trabalho de uma Comissão Real, um projeto preliminar e um projeto definitivo referentes aos dois primeiros livros do $\mathrm{CC}^{164}$. Nesses projetos, os conceitos de doação adotados - já diferentes entre si - eram substancialmente diversos daquele que viria a ser incluído no texto final.

O projeto preliminar, em seu art. 390, dispunha que "la donazione è un atto di liberalità tra vivi, con cui una persona attribuisca ad un'altra a titolo gratuito, una cosa o un diritto, ovvero la libera da un'obbligazione, o da un peso che gravi i suoi beni. La donazione produce i suoi effetti con l'accettazione"165.

Já o projeto definitivo, em seu art. 308, estabelecia que "la donazione è un atto con il quale una persona attribuisce ad un'altra, a titolo gratuito, la proprietà di una cosa 0 altro diritto reale non accessorio o un diritto di credito. La donazione si perfeziona con l'accettazione",166.

${ }^{163}$ Cf. II. 2.2

${ }^{164}$ Cf. N. Rondinone, Genesi e condizioni di utilizzo della Relazione al Codice Civile, in D. GRANDI, Relazione del Ministro Guardasigilli al Codice Civile - Riproduzione anastatica della G.U. del 4 aprile 1942 a cura del Consiglio Nazionale Forense, introduzioni di Giovanni B. Ferri e Nicola Rondinone, Roma, Istituto Poligrafico e Zecca dello Stato - Libreria dello Stato, 2009, $\mathrm{n}^{\mathrm{o}} 372$, pp. xxi-xxii. O projeto definitivo resultou de uma reformulação do preliminar após a realização de observações por órgãos técnicos e políticos, e foi seguido pelo parecer de uma comissão parlamentar.

${ }_{165}$ Cf. G. BonILINI, Delle donazioni - artt. 769-809, in E. GABRIELLI (org.), Commentario del codice civile, Torino, UTET, 2014, nt. 145:

Art. 390. La donazione è un atto di liberalità tra vivi, con cui una persona attribuisca ad un'altra a titolo gratuito, una cosa o un diritto, ovvero la libera da un'obbligazione, o da un peso che gravi i suoi beni. La donazione produce i suoi effetti con l'accettazione.

${ }^{166}$ Cf. G. BonILINI, Delle donazioni cit., nt. 145 e G. B. FERRI, Dall'intento liberale al cosidetto impegno etico e superetico cit., pp. 20-21:

Art. 308. La donazione è un atto con il quale una persona attribuisce ad un'altra, a titolo gratuito, la proprietà di una cosa o altro diritto reale non accessorio o un diritto di credito. La donazione si perfeziona con l'accettazione. 
As definições merecem atenção particularmente em dois pontos. Primeiro, ao contrário do texto final do Código, a doação no projeto preliminar ainda não era definida como contrato, mas como "ato" - dito "de liberalidade entre vivos", embora ambas as definições também previssem a necessidade de aceitação pelo donatário. O papel da aceitação parece ganhar força no projeto definitivo.

Enquanto no preliminar a aceitação é mera condição de eficácia, como se se tratasse de um negócio unilateral receptício, no definitivo a aceitação passa a ser necessária ao aperfeiçoamento da doação, já se aproximando à ideia de verdadeiro contrato. Segundo, a extensão do conteúdo da doação oscila entre um projeto e outro.

No preliminar, seu objeto abrangeria "coisa ou direito", sem limitação, e era consagrada expressamente a doação liberatória. No projeto definitivo, desapareceu a menção à "liberação de uma obrigação, ou de um ônus", e foi especificada a qualidade do direito que pode ser doado - propriedade, direito real não acessório e direito de crédito.

A Exposição de Motivos que acompanha o texto final do Código é bastante crítica quanto às definições anteriores de doação, especialmente a do projeto definitivo, em razão da limitação do seu âmbito. Destaca que seria preferível voltar à definição genérica e pouco precisa do art. 1.050 do CC de 1865 a adotar a solução do projeto definitivo, pois ao menos ela permitia margem para a interpretação ampla sobre o âmbito da doação ${ }^{167}$.

Os trabalhos de elaboração do Código passaram por relevante mudança em julho de 1939, quando GRANDI se tornou Ministro de Graça e Justiça - que na Itália tem o título de "Guardasigilli" - e constituiu comissões ministeriais com o objetivo de rever as bases do plano da codificação que estava sendo elaborada. O resultado final é a definição que consta no art. 769 do Código de 1942: "La donazione è il contratto, col quale, per spirito di liberalità, uma parte arrichisce l'altra, disponendo a favore di questa di um suo diritto o assumendo verso la stessa una obbligazione" $" 168$.

A disciplina da doação, no Título V ("Delle donazioni”), vem colocada dentro do Livro II, que trata do direito das sucessões ("Delle successioni”), o que pode parecer um retrocesso com relação à colocação ambígua adotada pelo CC anterior, como um "ponto de

${ }^{167}$ Cf. D. GRANDI, Relazione del Ministro Guardasigilli al Codice Civile cit., p. 77.

${ }^{168}$ Art. 769. La donazione è il contratto, col quale, per spirito di liberalità, uma parte arrichisce l'altra, disponendo a favore di questa di um suo diritto o assumendo verso la stessa una obbligazione. 
transição" entre o direito das sucessões e o das obrigações. O Livro II, inicialmente denominado "Delle successioni a causa di morte e delle donazioni", teve seu título substituído, no início de 1942, por uma fórmula mais sintética. Esta, ao excluir a referência às doações, acabou por inseri-las, ao menos formalmente, no direito das sucessões. Não se pode concordar, todavia, com a afirmação de AMENTA de que isso acaba por "ofuscar a real dimensão da sua qualificação contratual"169, uma vez que é expressamente definida como um contrato.

É, segundo a Exposição de Motivos, um contrato sui generis, cuja particular disciplina se assemelha, em alguns aspectos, à dos negócios mortis causa, mas ao qual também são aplicáveis as regras relativas aos contratos em geral. Por um lado, as regras especiais sobre a capacidade de dispor e receber, a nulidade pelo erro quanto aos motivos (art. 787) e pelo motivo ilícito (art. 788) e a possibilidade de redução por lesão à legítima evidenciariam a proximidade com a disciplina das sucessões; por outro, também seriam aplicáveis à doação as normas sobre o inadimplemento das obrigações e a eficácia translativa do consentimento (art. 1.376), próprias dos contratos ${ }^{170}$.

Com relação propriamente à definição de doação, vislumbra-se clara alteração quanto ao regime anterior. Os requisitos da atualidade e da irrevogabilidade foram retirados, por serem considerados inúteis relíquias do direito consuetudinário francês ${ }^{171}$. Além disso, o conceito procurou abarcar os três tipos de doação identificados pela doutrina prevalente - as doações reais, obrigatórias e liberatórias ${ }^{172}$.

A referência à "disposição de um direito" pretendia contemplar as doações real e liberatória, ou seja, tanto a transferência ou constituição de um direito real quanto a renúncia a um direito patrimonial já adquirido ${ }^{173}$. Já a doação obrigatória restou

${ }^{169}$ Cf. G. AMENTA, La donazione e la sua struttura contrattuale cit., p. 93.

${ }^{170}$ Cf. D. GRANDI, Relazione del Ministro Guardasigilli al Codice Civile cit., nº 371 e 372, pp. $77-78$.

${ }^{171}$ Cf. I.3.1.

${ }^{172}$ Trata-se das três modalidades de doação do direito romano clássico, cf. I.2.2.

${ }^{173}$ Cf. D. GRANDI, Relazione del Ministro Guardasigilli al Codice Civile cit., $\mathrm{n}^{\mathrm{o}}$ 372, pp. $77-$ 78. Segundo PICCININI, todavia, a expressão permanece sendo obscura, pois não esclarece o que se deve entender por disposição, cf. S. PICCININI, Profili della donazione dal codice 1865 ad oggi cit., p. 183. Segundo Mengoni e Realmonte, a distinção entre negócios de disposição e negócios obrigatórios é fundamental para o direito privado. Na doutrina alemã, os primeiros (Verfügung) são todos os negócios que produzem imediatamente a transferência, modificação e extinção de um preexistente direito subjetivo patrimonial. Distinguem-se dos negócios obrigatórios em razão da imediatidade do resultado final. A 
consagrada pela fórmula "assumir uma obrigação", que implica o surgimento de uma obrigação de o doador transferir o bem doado ao donatário. Com isso, afastou-se definitivamente da noção de doação do direito francês, e criou-se um novo regime ${ }^{174}$.

E essa nova disciplina da doação terá importantes consequências em relação aos temas tratados ao longo deste trabalho. É importante mencionar, por fim, que o CC it. de 1942 manteve o requisito da forma solene - "atto pubblico" - para a doação, sob pena de nulidade - art. 782. O art. 783 excepciona a regra para as doações de módico valor em que tenha havido a tradição.

\footnotetext{
"disposição" distingue-se da "atribuição patrimonial", que pode ser efetuada tanto por meio da disposição de um direito quanto da assunção de uma obrigação. Essas hipóteses estão compreendidas pelos negócios de atribuição, (Zuwendungen), cf. L. MENGONI - F. REALMONTE, Disposizione (atto di), in ED 13 (1964), p. 189. A afirmação da Exposição de Motivos, aliás, de que pretendia abarcar a doação liberatória não encontra confirmação unânime na doutrina. Para BISCONTINI, não se deve entender que o art. 769 abarcou a doação liberatória, pois tanto a remissão de dívidas quanto a renúncia a um crédito apresentam funções próprias, e não devem estar sujeitas à "normativa di freno" (i.e., a disciplina jurídica rigorosa) da doação, cf. G. BISCONTINI, Onerosità, corrispettività e qualificazione dei contratti - Il problema della donazione mista, Napoli, ESI, 1984, pp. 163-64.

${ }^{174}$ Apesar da consagração expressa da doação obrigatória no art. 769, o art. 771 do CC de 1942 contém ainda a vedação à doação de bens futuros:

Art. 771. La donazione non può comprendere che I beni presenti del donante. Se comprende beni futuri è nulla rispetto a questi, salvo che si trati di frutti ancora non separati.

Cf. R. LenzI, Donazione obbligatoria, in Contratto e impresa 19 (2003), pp. 1643-45, a doutrina discute a compatibilização entre os dois dispositivos e o que se deve entender por bens futuros (se compreendem, por exemplo, também os bens alheios). Há inclusive quem, para retirar aplicação ao dispositivo, permitindo a doação, entenda bens "futuros" como "todos os bens presentes e futuros", equiparando a vedação simplesmente à vedação das doações universais. Em sentido contrário, um entendimento amplo do que seriam bens futuros anularia completamente a possibilidade de doação obrigatória. Segundo LENZI, deve-se diferenciar a prestação futura de bens presentes (permitida nos termos do art. 769), da prestação futura de bens futuros. Por outro lado, o autor pondera que não seria razoável entender que é nula uma doação obrigatória de dinheiro que ainda não integrou o patrimônio do doador.
} 


\section{Contrato em espécie - a doação no Código Civil brasileiro}

\section{Das Ordenações Filipinas ao Código Civil de 2002 - alguns aspectos relevantes}

As Ordenações Filipinas foram o direito vigente no Brasil até a entrada em vigência do Código Civil de 1916. Não eram, porém, um Código no sentido moderno, de maneira que a matéria ali contida não era sistematizada no mesmo modo que nas codificações dos séculos XIX e XX ${ }^{175}$. Com relação à doação, sua principal preocupação, assim como a da ordonnance francesa de 1731, era com as formalidades impostas à sua prática. A insinuação ${ }^{176}$ era exigida para as doações acima de certo valor - que variava conforme o doador fosse homem ou mulher ${ }^{177}$ - e consistia primeiro na inquirição do doador, para verificar se houve "induzimento, arte, engano, medo, prisão ou outro algum conluio". Em seguida, eram inquiridos alguns vizinhos, "que tenham razão de saber como a doação foi feita". Somente após a conclusão de que a doação "foi feita bem", era expedida uma "Carta de confirmação" "178.

${ }^{175}$ Segundo BRAGA DA CRUZ, aliás, as Ordenações Filipinas, embora com alterações quanto à redação e à forma, não trouxeram grandes mudanças ou inovações de fundo quanto às Ordenações Manuelinas, as quais, por sua vez, eram simples atualização das Afonsinas. A razão disso é que foi elaborada, sob o domínio espanhol, pelo rei Filipe II da Espanha (Filipe I em Portugal) e promulgada em 1603 por Filipe III (Filipe II em Portugal). Esses monarcas, para não angariar antipatias, preocuparam-se em preservar a tradição do direito nacional português, sem a interferência do direito do país dominador. $\mathrm{O}$ resultado, todavia, é que já em 1603 as Ordenações eram “antigas" e "anacrônicas". Segundo o autor, trata-se de "une survivance du Moyen Age dans le Temps Modernes", cf. G. BRAGA DA CRUZ, La formation du droit civil portugais moderne et le Code Napoléon, in Obras esparsas II - Estudos de história do direito; Direito moderno $-2^{a}$ parte, Coimbra, Coimbra, 1981, pp. 3-4.

${ }^{176}$ FELÍ́CIO DOS SANTOS esclarece que, ao contrário do direito romano, "a insinuação não é exigida como meio de publicidade e como salvaguarda de direitos de terceiros, mas em fantasiado interesse do doador", cf. J. Felício dos SANTOS, Projecto do Codigo Civil brazileiro e commentario V, Rio de Janeiro, Laemmert, 1887, p. 43.

O autor, aliás, propõe o seguinte dispositivo que conceitua a doação:

Art. 2.372. Si o dono de uma cousa transfere, gratuitamente, para outrem o seu domio (sic) [“domínio"] sobre a mesma, e o donatário aceita, dá-se o contrato de doação.

${ }^{177}$ Ord. Filip. 4, 62, pr. Todas as doações, assi de bens moveis, como de raiz, como de huns e outros juntamente, que passarem de trezentos cruzados ou sua valia, serão insinuadas e approvadas per Nós, ou per os Desembargadores do Paço. E não sendo insinuadas, não valerão, salvo até a quantia de trezentos cruzados: e quanto ao mais, que passar da dita quantia, não valerão, nem terão vigor, como se nunca fossem feitas. E isto queremos que haja logar nas doações feitas per varões. $\mathrm{E}$ as doações feitas por mulheres, que vivam per si, quer solteiras, quer viuvas, que passarem de cento e cincoenta cruzados, ou sua valia, que cada huma valer ao tempo, que for feita, serão insinuadas; e a que o não fôr, valha sómente em quanto chegar á quantia de cento e cincoenta cruzados, e no que passar, não valha, nem tenha effeito, como se feita não fosse.

${ }^{178}$ Ord. Filip. 4, 62, 1. E a insinuação se fará, mandando tirar inquirição, em que primeiro será perguntado o que fez a doação, se a fez per induzimento, arte, engano, medo, prisão ou outro algum conluio, e se he contente, que a doação, per elle feita, seja per Nós confirmada e approvada. E bem assim devem ser perguntados alguns seus visinhos, que tenham razão de saber como a doação foi feita. A qual inquirição vista por Nós, ou pelos ditos Desembargadores, se per ella se mostrar, que foi feita bem, e como devia, e que 
A TeIXeIRA DE Freitas coube o trabalho de sistematizar a confusa legislação civil vigente à sua época, por meio de sua Consolidação das Leis Civis ${ }^{179}$. No caso da doação, foi disciplinada entre os arts. 411 e 419, cujo conteúdo fora extraído das Ordenações ${ }^{180}$. É importante notar que, antes do $\mathrm{BGB}^{181}$ e em sentido contrário ao Code civil, já inseriu a disciplina da doação no Título II - Dos Contratos em Particular (Capítulo I - Da doação) da Seção II - Dos direitos pessoais nas relações civis, do Livro I - Dos direitos pessoais da Parte Especial - abrindo caminho para a tradição da disciplina da doação entre os contratos, que persiste no direito brasileiro até hoje.

Essa colocação sistemática não iria ser alterada pelo Projeto de BEVILÁQUA, embora este, no art. 1.325, ainda definisse a doação como "ato entre vivos", o que evidencia certa ainda proximidade com o modelo francês: "Considera-se doação o ato entre vivos, pelo qual uma pessoa, por liberalidade, transfere de seu patrimônio uma cousa para com ela aumentar o de outra, que concorda em aceitá-la"182. Essa definição, porém,

aquelle, que a fez, he contente, que seja per nós confirmada, ser-lhe-ha dada nossa Carta de confirmação, e de outra maneira não.

${ }^{179}$ Segundo BRAGA DA CRUZ, as Ordenações não eram somente antiquadas, mas sobretudo defeituosas. Faltava-lhes clareza na linguagem, havia contradições frequentes e excessiva prolixidade nos preceitos legislativos, além do caráter extremamente lacunoso de suas disposições, cf. G. BRAGA DA CRUZ, La formation du droit civil portugais moderne et le Code Napoléon cit., pp. 4-5.

${ }^{180}$ Cf. A. TeIXEIRA DE FreitAS, Consolidação das Leis Civis, $3^{\mathrm{a}}$ ed., Rio de Janeiro, Garnier, 1876, pp. 284-89. Merecem destaque os arts. 411 a 416 :

Art. 411. Todas as doações de bens moveis, ou immoveis, que excedêderem de $360 \$ 000$ rs. sendo feitas por varão, e de $180 \$ 000$ rs. sendo feitas por molhér, devem sêr insinuadas.

Art. 412. A falta de insinuação annulla estes contractos, não no todo, mas somente no que passar das taxas estabelecidas.

Art. 413. A escriptura publica é da substancia da doação, sempre que esta dependa de sêr insinuada.

Art. 414. Deve sêr requerida a insinuação aos Juizes de primeira instancia, e averbada no Livro competente dentro de dois mezes á contar da data da escriptura.

Art. 415. Consiste a insinuação:

$\S 1^{\circ} \mathrm{Na}$ inquirição do doadôr sobre sua livre e espontanea vontade, sem influencia de qualquer engano, induzimento medo, ou conluio;

$\S 2^{\circ} \mathrm{Na}$ inquirição dos vizinhos do mesmo doadôr, que tenhão razão de sabêr como a doação foi feita.

Art. 416. Se pela inquirição ficar verificado o livre consentimento do doadôr, e removida toda suspeita de artificio, a doação será confirmada pelo Juiz.

${ }^{181}$ Livro II - Recht der Schuldverhältnisse [= "Diritto dei rapporti obbligatori], Seção VIII Einzelne Schuldverhältnisse [= "I singoli rapporti obbligatori”], Título IV - Schenkung [= Doação], cf. pp. S. PATTI (org.), Codice civile tedesco - Bürgerliches Gesetzbuch, Milano, Giuffrè-Beck, 2005, pp. xvii-xxi.

O CC port. de 1966 também disciplina a doação entre os contratos em espécie, no Livro II Direito das Obrigações, Título II - Dos contratos em especial, Capítulo II - Doação.

${ }^{182}$ Cf. C. Beviláqua, Projecto de Codigo Civil brazileiro, in Actas dos trabalhos da commissão revisora do Projecto de Codigo Civil brazileiro, Rio de Janeiro, Imprensa Nacional, 1901, pp. 204-05. 
não foi adotada no texto final, que, no art. 1.165 acabou por estabelecer: "Considera-se doação o contrato em que uma pessoa, por liberalidade, transfere do seu patrimônio bens ou vantagens para o de outra, que os aceita"183. O art. 538 do CC atual tem praticamente a mesma redação; só suprimiu, ao final, o trecho "que os aceita".

Ao contrário de Portugal, em que o CC de 1867 - chamado "Código de Seabra" - rompeu definitivamente com a tradição do direito português anterior, aproximando-se do modelo francês ${ }^{184}$, o direito civil no Brasil, entre muitas influências externas, manteve uma maior linha de continuidade com a tradição luso-brasileira anterior, na qual ocupou posição de centralidade a figura de TEIXEIRA DE FREITAS. Todavia, tanto o Projeto de BEVILÁQUA quanto o $\mathrm{CC}$ afastaram-se do conceito de doação adotado no Esboço.

${ }^{183}$ Essa redação, aliás, foi praticamente mantida no Anteprojeto de Código das Obrigações de 1963, de Caio Mário da Silva Pereira, cf. L. C. B. Rangel - C. A. S. LoPes (org.), Código Civil: anteprojetos III - Anteprojetos de Código de Obrigações, Brasília, Senado Federal - Subsecretaria de Edições Técnicas, 1989, p. 57:

Art. 415. Pelo contrato de doação uma pessoa, por liberalidade, transfere de seu patrimônio bens ou vantagens, para o de outra que os aceita.

${ }^{184}$ Segundo POUSADA, Teixeira de Freitas "evidencia todo o seu respeito pela tradição jurídica luso-brasileira - tributária do renascimento do direito justinianeu na segunda metade do século XIII", uma tradição que seria "renegada por Portugal em 1867, com a promulgação do Código Civil elaborado por V. de Seabra", cf. E. L. R. POUSADA, Preservação da tradição jurídica luso-brasileira: Teixeira de Freitas e a Introdução $a$ Consolidação das Leis Civis, Dissertação (Mestrado), São Paulo, Faculdade de Direito da Universidade de São Paulo, 2006, p. 17. Segundo BRAGA DA CRUZ, todavia, o CC de 1967 não teria operado um rompimento abrupto, mas a influência do Code Napoléon teria sido fruto de uma lenta difusão dos preceitos e diretrizes do CC fr., na jurisprudência e doutrina portuguesas ao longo dos sessenta anos que separam a promulgação dos dois Códigos, cf. G. BRAGA DA CRUZ, La formation du droit portugais moderne et le Code Napoléon cit., pp. 1-2.

Apesar disso, a definição de doação contida no CC de 1867 tem diferenças consideráveis com relação ao art. 894 do $\mathrm{CC}$ fr.:

Art. 1.452. Doação é um contrato, por que qualquer pessoa transfere a outrem gratuitamente uma parte, ou a totalidade de seus bens presentes.

Cf. L. Cunha Gonçalves, Tratado de direito civil em comentário ao Código Civil português VIII-I, $2^{\mathrm{a}}$ ed. ( $1^{\mathrm{a}}$ ed., bras.), São Paulo, Max Limonad, 1956, p. 72.

O CC port. atual, por outro lado, ao menos no que se refere à definição de doação, filiou-se ao CC it. de 1942, cf. F. A. PIRES De LimA - J. M. Antunes VARela, Código civil anotado II - Artigos $762^{\circ}$ a $1250^{\circ}, 4^{\mathrm{a}}$ ed., Coimbra, Coimbra, 1997, p. 236. A definição legal, com efeito, é bastante semelhante à do art. 769 do CC it.:

Art. $940^{\circ}, 1$. Doação é o contrato pelo qual uma pessoa, por espírito de liberalidade e à custa do seu patrimônio, dispõe gratuitamente de uma coisa ou de um direito, ou assume uma obrigação, em benefício do outro contratante. 
Este, que também incluía a doação entre os contratos em espécie ${ }^{185}$, definia-a em seu art. 2.119: "Haverá doação, quando, para o fim de transferir domínio, uma das partes se tiver obrigado a entregar, gratuitamente, à outra parte uma coisa com valor por si”. Como visto, o conceito de doação do art. 894 do CC fr. admite somente as doações in dando, enquanto o art. 769 do CC it. admite também as doações in obligando.

Nota-se, desde logo, que TEIXEIRA DE FREITAS adotou explicitamente o modelo das doações in obligando: "se tiver obrigado a entregar". Já o CC, na linha do Projeto de BEVILÁQUA, parece adotar o modelo francês das doações in dando ao utilizar a oração "transfere do seu patrimônio" (atual art. 538), embora a sua inserção no Livro I - Do direito das obrigações torne a opção do legislador, no mínimo, ambígua. Como se verá, a discussão sobre se o contrato de doação é real ou consensual é uma das principais travadas pela doutrina pátria ${ }^{186}$.

Quanto aos requisitos formais, o CC de 1916 os abrandou de maneira significativa, principalmente se forem levadas em consideração as formalidades da insinuação previstas nas Ordenações Filipinas, e a exigência da forma solene que persiste até os dias de hoje nos Códigos francês (art. 932) e italiano (art. 782) ${ }^{187}$. Parece ter seguido o modelo do Esboço, em que a escritura pública era exigida somente em casos determinados sob pena de nulidade ${ }^{188}$.

O art. 1.168 do CC de 1916 previu simplesmente que "a doação far-se-á por instrumento público, ou particular”, em regra que foi repetida no atual art. 541. A única

${ }^{185}$ Seção III - Dos direitos pessoais nas relações civis, Título I - Das obrigações derivadas dos contratos, Capítulo IV - Da doação, cf. A. TeIXEIRA DE FreitAS, Esboço do Código Civil II, Brasília. Ministério da Justiça - Fundação Universidade de Brasília, 1983, pp. v-vi.

${ }^{186}$ Cf. I.6.1.

brazileiro cit., p. 205:

${ }^{187} \mathrm{O}$ abrandamento já constava do Projeto, cf. C. BEviLÁQuA, Projecto de Codigo Civil

Art. 1.329. A doação deve ser feita por instrumento público ou particular, conforme forem móveis ou de raiz os bens doados.

Parágrafo único. A doação verbal será válida se, versando sobre bens móveis e de pequeno valor, for imediatamente seguida de tradição.

${ }^{188}$ Art. 2.150. Devem ser feitas por escritura pública, sob pena de nulidade, e sem que neste caso tenha aplicação o disposto nos arts. 1.929 e 1.934:

$1^{\circ}$ As doações de imóveis e de embarcações do alto mar.

$2^{\circ}$ As doações remuneratórias e doações com encargos (art. 2.121).

$3^{\circ}$ As doações de um esposo a outro para depois de seu falecimento (arts. 1.241, 1.244 e

1.327).

$4^{\circ}$ As doações de prestações periódicas, perpétuas, vitalícias e não vitalícias. 
exigência é a forma escrita, não necessariamente solene, a não ser nas hipóteses de "negócios jurídicos que visem à constituição, transferência, modificação ou renúncia de direitos reais sobre imóveis de valor superior a trinta vezes o maior salário mínimo vigente no País", em razão do disposto no art. 108. Além disso, o parágrafo único do art. 541 assim como o do antigo art. 1.168 - prevê uma hipótese de exceção à exigência de forma escrita: "a doação verbal será válida, se, versando sobre bens móveis e de pequeno valor, lhe seguir incontinenti a tradição".

\section{Estrutura bilateral e necessidade de aceitação}

A doação no $\mathrm{CC}$ brasileiro, como visto, é disciplinada como contrato. Como tal, é negócio jurídico bilateral, formado por proposta e aceitação. Esta última é necessária para a estrutura contratual, pois, segundo PONTES DE MIRANDA, transferências de bens sem uma manifestação expressa ou tácita do donatário "são simples ofertas" ou "simples elementos do suporte fático" "189 . Conforme mencionado, o CC de 1916 dispunha em seu art. 1.165 que a doação é "o contrato em que uma pessoa, por liberalidade, transfere do seu patrimônio bens ou vantagens para o de outra, que os aceita".

$\mathrm{O}$ atual art. 538 manteve a definição, mas suprimiu a parte final. Essa retirada, porém, não é considerada relevante para a definição do nosso instituto como contrato. É tida, aliás, como salutar, pois a oração "que os aceita" seria excessiva e desnecessária 190 . Há outros dispositivos do CC atual que em uma primeira leitura poderiam dar ensejo a questionamentos quanto à natureza de negócio jurídico bilateral a doação ${ }^{191}$. O primeiro é

${ }^{189}$ Cf. F. C. PONTES DE MIRANDA, Tratado de direito privado XLVI-Parte especial - Direito das obrigações: Contrato de seguro (continuação). Seguro de vida. Seguros de acidentes pessoais. Seguro de responsabilidade. Seguro de crédito. Seguro de riscos especiais e de universalidade. Seguros mútuos. Resseguro. Contrato de comodato. Contrato de doação. Contrato de hospedagem, $3^{\mathrm{a}}$ ed., Rio de Janeiro, Borsoi, 1972, pp. 192 e 198. No mesmo sentido, "a aceitação decorre, naturalmente, da própria natureza contratual de que se reveste a doação", cf. S. CAPANEMA DE SouZA, Comentários ao novo Código Civil VIII - Das várias espécies de contrato. Da troca ou permuta. Do contrato estimatório, Da doação. Da locação de coisas (arts. 533 a 578), in S. F. TEIXEIRA (coord.), Comentários ao novo Código Civil, Rio de Janeiro, Forense, 2004, p. 113.

${ }^{190}$ Cf. N. Rosenvald, Arts. 481 ao 652 - Contratos (em espécie), in C. Peluso (coord.), Código Civil comentado, Barueri, Manole, 2007, p. 424.

${ }^{191}$ Além dos dispositivos tratados no corpo do texto, o art. 546 dispõe que a doação feita em contemplação de casamento futuro com certa e determinada pessoa "não pode ser impugnada por falta de aceitação". Essa regra, contudo, não oferece grandes dificuldades, pois parece consagrar uma verdadeira aceitação presumida, que não afasta a estrutura contratual da doação, cf. F. C. PONTES DE MIRANDA, Tratado 
o art. 539, que permite ao doador "fixar prazo ao donatário, para declarar se aceita ou não a liberalidade", ao final do qual o seu silêncio será interpretado como aceitação - "entenderse-á que aceitou" -, se não houver encargo. O art. 111 não deixa dúvidas de que silêncio pode ser declaração negocial ${ }^{192}$.

Porém, pode-se afirmar que o dispositivo incorre em erro ao contrapor o silêncio à "vontade expressa", como se de "vontade tácita" se tratasse. JUNQUEIRA DE AZEVEDO a esse respeito reporta-se ao art. $217^{\circ}$, 1 , do CC port., segundo o qual a declaração "é expressa, quando feita por palavras, escrito, ou qualquer meio direto de manifestação da vontade, e tácita, quando se deduz de fatos que, com toda a probabilidade, a revelam" ${ }^{\prime 193}$.

Nesse sentido, o silêncio é sempre uma declaração omissiva ${ }^{194}$, mas tanto pode ser declaração expressa quanto tácita, respectivamente, conforme implique um meio direto de manifestação da vontade ou dê ensejo a um juízo de probabilidade quanto ao sentido da declaração. No caso do art. 539, o silêncio do donatário não só constitui a aceitação, como é meio direto de manifestação da vontade. Esse dispositivo, aliás, não faz mais do que repetir a regra contida no art. 432, segundo a qual no negócio "em que não seja costume a aceitação expressa" ou em que "proponente a tiver dispensado, reputar-se-á concluído o contrato, não chegando a tempo a recusa".

A partir do art. 539, portanto, não se pode inferir nenhuma particularidade ou exceção com relação à estrutura bilateral da doação. A aceitação propriamente tácita, por outro lado, também é admissível, e "se verificará se o donatário recebe a coisa do doador, através de tradição real, e passa imediatamente a usá-la, ainda que sem qualquer

de direito privado XLVI cit., p. 228: "Se a doação foi para o caso de casamento com determinada pessoa, o que se há de presumir é que o outorgado aceitou”.

${ }^{192}$ Art. 111. O silêncio importa anuência, quando as circunstâncias ou os usos o autorizarem, e não for necessária a declaração de vontade expressa.

${ }^{193}$ Cf. A. JUNQUEIRA DE AZEVEDO, Negócio jurídico - Existência, validade e eficácia, $4^{\mathrm{a}}$ ed., São Paulo, Saraiva, 2002, p. 126. Esses conceitos de declaração expressa e tácita parecem corresponder, grosso modo, aos conceitos de "declaração" e "comportamento" mencionados por BETTI como os modos por meio dos quais se pode praticar o negócio jurídico, cf. E. BETTI, Teoria generale del negozio giuridico (1943), reed. (2 ${ }^{\mathrm{a}}$ ed., $3^{\mathrm{a}}$ reimpr., 1960), $1^{\mathrm{a}}$ reimpr. (1994), Napoli, ESI, 2002, p. 127.

${ }^{194}$ A forma ativa refere-se a negócios em que "o agente modifica o mundo exterior", a omissiva a negócios "que se consubstanciam em inércia" e em que "não há alteração do mundo exterior". Nesse sentido, o silêncio será sempre uma declaração omissiva, que poderá ser expressa ou tácita a depender das circunstâncias, cf. A. JUNQUEIRA DE AZEVEDO, Negócio jurídico cit., pp. 127-28. 
manifestação escrita ou verbal”" ${ }^{\text {"195 }}$. Nas palavras de PONTES DE MIRANDA, a oferta seguida da transmissão do bem “dá a posse ao outorgado e o seu exercício compõe aceitação tácita" ${ }^{196}$.

O segundo dispositivo que merece exame é o art. 543, que determina: "se o donatário for absolutamente incapaz, dispensa-se a aceitação, desde que se trate de doação pura". Nesse caso, o problema é maior, pois a lei expressamente exclui a necessidade de aceitação, o que parece contraditório com a estrutura bilateral. Esse artigo veio em substituição art. 1.170 do CC de 1916, segundo o qual "às pessoas que não puderem contratar é facultado, não obstante, aceitar doações puras".

ALVIM, o responsável pela elaboração do anteprojeto que deu origem ao atual Livro I da Parte Especial, criticava as "intermináveis controvérsias" a que dava margem a regra anterior ${ }^{197}$. Argumentava que "a lei poderia ter estabelecido uma presunção de aceitação" ou "até mesmo, desviando-se do sistema, dispensar a aceitação", pois "o

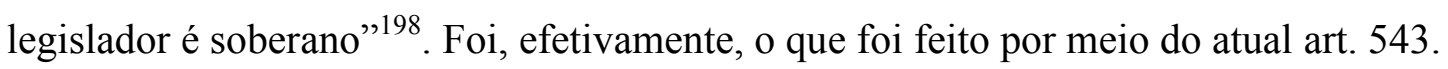

VILLELA, contudo, aponta que a nova redação é inaceitável. O antigo art. 1.170 seria exceção à regra da capacidade do agente como requisito de validade do negócio jurídico, uma "aplicação tópica" segundo a qual a intervenção do representante seria dispensada "quando o ato praticado pelo menor só lhe proporcionar vantagem"199. Já o atual art. 543 implicaria negar pura e simplesmente o consentimento aos incapazes, o que é um "desatino" que "não tem precedentes no direito brasileiro".

Através dessa regra, o CC estaria submetendo o menor "a uma estranha sujeição: a de ser dono contra a própria vontade", através de uma concepção errônea de que a aquisição da propriedade sempre é benéfica ao seu titular. Seria até razoável

${ }^{195}$ Cf. S. CAPAnema de SouZA, Comentários ao novo Código Civil VIII cit., p. 118.

${ }^{196}$ Cf. F. C. PONTES DE MIRANDA, Tratado de direito privado XLVI cit., p. 227.

${ }^{197}$ O problema enfrentado pela doutrina era a contradição com o art. 427, III, do CC de 1916, que conferia ao tutor, com autorização do juiz, a competência para aceitar "doações, com ou sem encargos", feitas ao tutelado. A regra foi mantida no atual art. 1.748, II, mas a redação foi atualizada para "doações, ainda que com encargos".

${ }^{198}$ Cf. A. AlviM, Da doação, $2^{\text {a }}$ ed., São Paulo, Saraiva, 1972, pp. 87 e 89.

${ }^{199}$ Essa ideia é derivada do disposto no da ideia contida no 107 do BGB, cf. J. B. VILLELA, Contrato de doação - Pouca luz e muita sombra, in A. J. PEREIRA JúNIOR - G. H. JABUR (coord.), Direito dos contratos, São Paulo, Quartier Latin, 2006, pp. 272-74. 
estabelecer uma presunção de aceitação, mas não dispensá-la completamente ${ }^{200}$. De todo modo, o art. 543 é um dado legislativo com o qual se deve lidar. Uma opção é entendê-lo como uma aceitação ficta ${ }^{201}$. Além disso, por ser excepcional, não serve para pautar a discussão a ponto de levar a um questionamento da estrutura bilateral da doação.

${ }^{200}$ Para Villela, é fruto de uma época em que pouco se discutiam questões como a função social e a responsabilidade civil pelo fato da coisa, e na qual "o direito de propriedade gozava de um manifesto glamour". Ignorava-se, por exemplo, a possibilidade de que o bem doado pudesse causar danos ao donatário. Além disso, ao mencionar somente os absolutamente incapazes, o Código é contraditório ao excluir do "suposto benefício" os relativamente incapazes, cf. J. B. VILlELA, Contrato de doação cit., pp. 272-75. Acrescentamos que talvez a razão disso seja que se tenha entendido que a regra era desnecessária para os relativamente incapazes, pois o art. 105 já dispõe que a "incapacidade relativa de uma das partes não pode ser invocada pela outra em benefício próprio", além de a incapacidade relativa gerar somente a anulabilidade do negócio (art. 171, I).

${ }^{201}$ Cf. S. CAPanema de Souza, Comentários ao Código Civil VIII cit., p. 92. Para esse autor, “a construção legal é artificiosa, mas admissível, em razão do caráter benéfico da doação, sendo ela pura, o que não poderá trazer para o incapaz qualquer prejuízo". 


\section{Contrato real, contrato consensual e contrato preliminar de doação}

\section{Contrato real ou contrato consensual?}

Uma das grandes questões discutidas pela doutrina brasileira é se o contrato de doação é consensual ou real. É preciso ressaltar, em primeiro lugar, que o termo "consensual" pode ser utilizado com dois significados. Em oposição a contrato formal, contrato consensual é aquele em que a forma não é necessária para a sua validade. Em oposição a contrato real, o consensual é o contrato que se forma pelo simples consentimento, sem necessidade da entrega de uma coisa. Neste trabalho, o termo consensual será utilizado no segundo sentido. Se for adotado o primeiro, a doação obviamente será um contrato formal, pois demanda a forma escrita, salvo no caso dos bens móveis de pequeno valor acompanhados da tradição imediata (art. 541).

É tendo em vista o primeiro sentido, por exemplo, que PENTEADO afirma que a exigência legal da forma impossibilita o entendimento de que se trate de contrato simplesmente consensual ${ }^{202}$. É necessário estar atento a isso na leitura da doutrina pátria, pois às vezes os autores parecem entrar em contradição. PEREIRA, por exemplo, em um primeiro momento recusa a natureza consensual da doação, afirmando que "o legislador não considerou que o consentimento, por si só, é suficiente à sua perfeição" (primeiro sentido). Páginas adiante, porém, afirma que a doação é contrato consensual, pois "cria a obrigação de transferir a propriedade da coisa doada" (segundo sentido) ${ }^{203}$. Talvez seja em virtude da confusão entre os dois sentidos, aliás, que ALVIM, após definir a doação como um contrato formal, afirma que não é nem real nem consensual ${ }^{204}$.

Aqui, conforme mencionado, será relevante o segundo sentido - contrato consensual em oposição a real - e esse é um ponto em que a literatura brasileira é “confusa, lacunar e imprecisa" ${ }^{205}$. Para parte considerável da doutrina o contrato de doação é consensual, ou seja, consiste em um acordo entre doador e donatário por meio do qual

\footnotetext{
${ }^{202}$ Cf. L. C. PenteAdo, Doação com encargo e causa contratual - Uma nova teoria do contrato, $2^{\text {a }}$ ed., São Paulo, RT, 2013, pp. 311-12.

${ }^{203}$ Cf. C. M. S. PEREIRA - R. FICHTNER, Instituições de direito civil III - Contratos. Declaração unilateral de vontade. Responsabilidade civil, 12a ed., Rio de Janeiro, Forense, 2006, pp. 247 e 259.

${ }^{204}$ Cf. A. Alvim, Da doação cit., p. 7.

${ }^{205}$ Cf. J. B. Villela, Contrato de doação cit., p. 261.
} 
aquele se obriga a adimplir uma prestação em face deste ${ }^{206}$. Segundo esse entendimento, a doação como contrato real estaria restrita unicamente à hipótese da doação de bens móveis de módico valor (art. 541, par. ún).

Essa doutrina tem apoio na disciplina da doação como uma das "várias espécies de contrato" (Titulo VI), que se insere no livro que trata "Do direito das obrigações" (Livro I da Parte Especial). Todavia, o texto do art. 538 parece indicar que é contrato real, pois define a doação como o contrato em que uma pessoa transfere bens para o patrimônio de outra, e não se obriga a transferir. A diferença é nítida com relação ao art. 481, que define a compra e venda como o contrato pelo qual "um dos contratantes se obriga a transferir o domínio de certa coisa, e o outro, a pagar-lhe certo preço em dinheiro".

Para Bodin DE MoRAIS, o uso do termo "transfere" é apenas uma "falha legislativa”. O CC "na verdade deveria ter adotado a expressão composta 'se obriga a transferir' - como fizera na previsão da compra e venda"207. Porém, pondera VILLELA que “quem diz transfere, não diz se obriga a transferir, ou promete transferir", isto é, não se pode ignorar o texto do legislador. Para ele, a transferência é ato formativo do contrato, ou seja, deve ocorrer concomitantemente ao acordo ${ }^{208}$. É diferente da compra e venda, na qual

${ }^{206}$ Definem a doação como contrato consensual S. CAPANEMA DE SOUZA, Comentários ao novo Código Civil VIII cit., p. 88, O. GoMES - A. JunQueIRA DE AZEVEDo, F. P. D. C. MARINO, Contratos, $26^{\mathrm{a}}$ ed., Rio de Janeiro, Forense, 2007, p. 253, A. WALD, (parecer) Do regime jurídico da doação de bens móveis feita por ascendente a descendente, in Revista Forense 89 (1993), p. 139, C. M. S. PEREIRA - R. FiCHTNER, Instituições de direito civil III cit., p. 259, N. RosenvalD, Arts. 481 ao 652 - Contratos (em espécie) cit., p. 424. Por outro lado, autores que defendem a doação como um contrato real: Cf., por exemplo, P. L. N. LôBo, Comentários ao Código Civil VI - Parte especial - Das várias espécies de contratos (arts. 481 a 564), in A. JunQueIRA de AZEVedo (coord.), Comentários ao Código Civil, São Paulo, Saraiva, 2003, p. 273, cf. N. NERY JR. - L. C. PENTEADO, Doação pura, preliminar de doação e contratos de gestão, in RDPriv 7 (2006), p. 29, J. B. VILlEla, Contrato de doação cit., p. 270. Para PENTEADO, a caracterização majoritária da doação como contrato consensual deve-se a "uma ligeira confusão entre a necessidade da aceitação para a formação de qualquer ato jurídico bilateral (no caso, do contrato), com o caráter real ou consensual do contrato, relacionada ao elemento ou conjunto de elementos determinantes do momento de início de sua eficácia própria", cf. L. C. PENTEADO, Doação com encargo e causa contratual cit., pp. 311-12.

${ }^{207}$ Cf. M. C. BODIN DE MORAES, Notas sobre a promessa de doação cit., p. 4.

${ }^{208}$ Para JUNQUEIRA DE AZEVEDO, "a entrega da coisa nos contratos reais é causa pressuposta deles", a qual não é "elemento do negócio, senão requisito de validade". Assim, "a efetiva entrega da coisa não faz parte, portanto, da existência dos 'contratos reais', mas sim somente influi sobre sua validade", cf. A. JunQUEIRA DE AZEVEDO, Negócio jurídico cit., p. 36, nt. 54. NERY e PENTEADO, todavia, parecem colocar a questão como elemento de existência: "sem a efetiva transferência, não há a configuração de um elemento mínimo que é constitutivo do cerne da estrutura nuclear do suporte fático do tipo donativo, qual seja, o deslocamento patrimonial. Sem deslocamento, não há doação". Afirmam ainda que "doação de coisa futura é 
se separa o ato de formação - acordo - do ato de execução - transferência. Enquanto a compra e venda seria uma promessa passível de ser descumprida, a doação seria já uma atribuição patrimonial $^{209}$.

Entender que a doação é um contrato real pode causar perplexidade justamente em razão da sua inserção no livro das obrigações, porque a entrega da coisa exaure praticamente por completo a eficácia típica do contrato, e nenhuma obrigação surge para as partes $^{210}$. O problema não surge nos demais contratos reais, em que o surgimento da obrigação decorre justamente da entrega da coisa ${ }^{211}$.

É verdade que no direito estrangeiro encontram-se exemplos de ambas as modalidades. Na França, a doação é real ou in dando. Na Itália, pode ser tanto real quanto consensual - in dando e in obligando. Porém, nesses países a doação não é disciplinada junto ao direito das obrigações. Além disso, falar em doação in dando nesses lugares tem um significado diverso. Ao contrário do direito brasileiro, o contrato tem efeitos reais, isto é, transfere automaticamente a titularidade do direito à outra parte. É o chamado sistema do sistema do consenso translativo ${ }^{212}$.

negócio inexistente, pela falta da 'transferência de bens ou vantagens"', cf. N. NERY JR. - L. C. PENTEADO, Doação pura, preliminar de doação e contratos de gestão cit, pp. 24 e 29.

${ }^{209}$ Cf. J. B. VILlELA, Contrato de doação cit., pp. 262-64 e 270. O autor conclui que "no rigor da sua positividade jurídica, a doação é um contrato real e unilateral sob condição resolutória meramente potestativa". A "manifestação de vontade do outorgante, na doação, não é a de contrair dever e obrigação de prestar ao outorgado", mas "apenas consiste na própria dádiva", cf. F. C. PONTES DE MIRANDA, Tratado de direito privado XLVI cit., pp. 201, 229, 232 e 282.

${ }^{210}$ Segundo VILLELA, restarão apenas efeitos secundários, como a possibilidade de revogação por ingratidão e inexecução do encargo (art. 555), cf. J. B. VILLELA, Contrato de doação cit., pp. 263 e 270. $\mathrm{O}$ autor pergunta: com a transferência dos bens ou vantagens, o que mais ao doador restaria prestar? A resposta: "Nada. Absolutamente nada" (p. 263).

${ }^{211}$ No comodato, é obrigação do comodatário "conservar, como se sua própria fora, a coisa emprestada", usá-la "de acordo com o contrato ou a natureza dela" (art. 582) e restituí-la no "prazo convencional" ou "necessário para o uso concedido" (art. 581). No mútuo, o mutuário "é obrigado a restituir ao mutuante o que dele recebeu em coisa do mesmo gênero, qualidade e quantidade" (art. 586). No depósito voluntário, o depositário "é obrigado a ter na guarda e conservação da coisa depositada o cuidado e diligência que costuma com o que lhe pertence, bem como a restituí-la, com todos os frutos e acrescidos, quando o exija o depositante" (art. 629).

${ }^{212}$ Cf. J. M. Antunes Varela, Das obrigações em geral I, $10^{\mathrm{a}}$ ed., $4^{\mathrm{a}}$ reimpr. (2006), Coimbra, Almedina, 2000, pp. 300-01. O sistema foi inaugurado pelo CC francês e adotado, por exemplo, pelos direitos italiano e português. Especificamente com relação à doação, dispõe o art. 938 do Code civil: "La donation dûment acceptée sera parfaite par le seul consentement des parties ; et la propriété des objets donnés sera transférée au donataire, sans qu'il soit besoin d'autre tradition". O art. 1376 do CC italiano, por sua vez, sob a rubrica "contratto con effetti reali", dispõe que "nei contratti che hanno per oggetto il trasferimento della proprietà di una cosa determinata, la costituzioni o il trasferimento di un diritto reale ovvero il trasferimento di un altro diritto, la proprietà o il diritto si trasmettono e si acquistano per effetto del 
No Brasil, esse efeito translativo não é admitido, pois há uma separação entre os planos dos direitos reais e dos direitos obrigacionais que demanda um ato posterior de transferência para que se opere a transmissão do direito ${ }^{213}$. A transferência deve ser feita pela tradição, no caso de bens móveis (art. 1267), ou pelo registro do título translativo no Registro de Imóveis, no caso de imóveis (art. 1245), salvo indireta ${ }^{214}$.

Um argumento favorável ao caráter consensual da doação é a previsão das doações "em forma de subvenção periódica" (art. 545), nas quais parece haver uma "relação obrigacional prévia à entrega de bem, característica dos contratos consensuais, de modo que a tradição não é elemento do contrato, mas adimplemento”. Segundo PENTEADO, todavia, o dispositivo poderia ser interpretado como um contrato preliminar de doações reais periódicas ${ }^{215}$, embora, como será visto, a admissibilidade de um contrato preliminar de doação é bastante questionada ${ }^{216}$.

Na realidade, parece razoável a posição de PONTES DE MiRANDA, para quem nosso direito admite duas espécies de doação - a real e a consensual. Em regra, a doação é contrato real, mas, excepcionalmente, pode ser contrato consensual, como no caso da doação em forma de subvenção periódica e no caso de as partes, com base em sua autonomia privada, decidirem dar ao acordo estrutura diversa da prevista no art. 538, que, segundo PONTES DE MIRANDA, traz regra dispositiva ${ }^{217}$.

A dificuldade enfrentada por alguns em admitir a doação consensual diz respeito, na realidade, à dificuldade em se admitir que o donatário possa exigir que o doador entregue os bens gratuitamente prometidos, tema deve ser tratado em conjunto com a discussão sobre a admissibilidade do contrato preliminar de doação.

consenso delle parti legittimamente manifestato". Por fim, o art. 408 ${ }^{\circ}$, 1, do CC português, intitulado "contratos com eficácia real", determina que "a constituição ou transferência de direitos reais sobre coisa determinada dá-se pelo mero efeito do contrato, salvo as exceções previstas em lei".

${ }^{213}$ Cf. C. V. Couto E Silva, A obrigação como processo (1964), reed., Rio de Janeiro, FGV, 2006, pp. 49-52.

${ }^{214}$ Cf. II.5.2.

${ }^{215}$ Cf. L. C. Penteado, Doação com encargo e causa contratual cit., p. 314, no mesmo sentido de F. C. PONTES DE MIRANDA, Tratado de direito privado XLVI cit., pp. 201-04 e 266.

${ }^{216}$ Cf. I.6.2.

${ }^{217}$ Cf. F. C. PONTES DE MIRANDA, Tratado de direito privado XLVI cit., pp. 201-04 e 266. 


\section{Contrato preliminar de doação na doutrina e jurisprudência}

Embora a figura do contrato preliminar seja expressamente admitida pelo CC brasileiro, e disciplinada nos arts. 462 a 466, existe uma tendência bastante difundida em rechaçar a sua aplicabilidade ao contrato de doação - a chamada "promessa de doação"218. A razão disso, de acordo com PereirA, está no fato de que é de sua essência a "criação de um compromisso dotado de exigibilidade", o que implica a possibilidade de o promitentedonatário exigir a realização da doação pelo promitente-doador. O problema disso é que haveria "uma doação coativa, doação por determinação da justiça, liberalidade por imposição do juiz e ao arrepio da vontade do legislador", o que não "se coaduna com a essência da doação"219.

Para VILLELA, "não pode haver promessa de doação pela mesma razão que não pode haver promessa de comodato, promessa de mútuo gratuito ou promessa de depósito gratuito" 220 . A razão disso é que a gratuidade é insuscetível "de ser imposta contra a vontade do beneficente" ${ }^{221}$. Os negócios gratuitos seguiriam lógica própria. A ausência de contraprestação ou sinalagma faria com que o "tropismo de proteção da ordem jurídica" fosse "manifestamente mais ativo", assegurando, "por um natural expediente reequilibrador", "que a perda se dê na estrita medida do que se propõe o agente". E uma

${ }^{218}$ O termo mais adequado para se referir ao instituto é "contrato preliminar de doação", pois o termo "promessa" poderia acarretar alguma confusão com negócios jurídicos unilaterais como a promessa de recompensa (art. 854 e seguintes), embora a própria disciplina do CC do contrato preliminar reserve o termo promessa àquela unilateral, na qual o credor deve se manifestar dentro de um prazo (art. 466). De todo modo, não há dúvidas de que a doutrina e jurisprudência que cuidam da "promessa" de doação, na realidade, se referem ao "contrato preliminar". No nosso texto, as expressões serão utilizadas como equivalentes.

${ }^{219}$ Cf. C. M. S. PEREIRA - R. FICHTNER, Instituições de direito civil III cit., pp. 257-58.

${ }^{220}$ Em sentido contrário, cf. P. MOROZZO DELLA ROCCA, Gratuità, liberalità e solidarietà Contributo allo studio della prestazione non onerosa, Milano, Giuffrè, 1998, pp. 116-17. Para esse autor não há obstáculo à admissão de contrato preliminar de contratos gratuitos, até porque o CC italiano não traz nenhuma limitação nesse sentido. Uma questão um pouco diversa é se é admissível a celebração de contratos consensuais de comodato ou depósito, uma vez que são previstos como contratos reais. Segundo ele, como a lei exige a entrega para a completude da fattispecie, não poderia o intérprete arbitrariamente ter entendimento diverso, pois a norma que exige a entrega da coisa seria cogente.

${ }^{221}$ Cf. J. B. Villela, Contrato de doação cit., p. 270. Chamoun, por sua vez, afirma que "no direito brasileiro, como em outros, a promessa de doação é nula", pois "o animus donandi deve ser atual, isto é, existente no momento da doação". Para o estudioso, seria "válido o arrependimento de quem apenas prometeu doar, que se interpõe entre a promessa de doar e o momento em que ela se cumpriria". Conclui no sentido de que é possível "constranger o doador, que contratou, a entregar o que doou, mas não se pode compeli-lo a doar”, cf. E. CHAMOUn, (parecer) Doações sujeitas a termo e condição. Invalidade de cláusula relativa à destinação dos bens após o termo e condição, in Revista Forense 96 (2000), p. 189. 
maneira de garantir isso seria "reter" a consumação do ato de disposição gratuito "até o último momento", para que o agente "esteja particularmente seguro de sua intenção",222.

Tal posicionamento tem predominado na jurisprudência do STJ. O tribunal há bastante tempo vem entendendo que a promessa de doação é inadmissível, abrindo exceção somente para casos de divórcio ou separação judicial, em que os casais, no ato de partilha judicial, preveem a doação de bens - principalmente imóveis - a seus filhos. CARNAÚBA e REINIG $^{223}$, que analisaram acórdãos daquela Corte, concluem que a posição do STJ oscilou.

Inicialmente entendeu ser toda a promessa de doação judicialmente inexigível (REsp $23.507^{224}$ e REsp $30.647^{225}$ ); depois passou a entender ser possível a doação de “imóvel ao filho do casal, por ocasião do acordo realizado em autos de separação consensual" (REsp $32.895^{226}$ ), entendimento este que foi confirmado pela Segunda Seção (EREsp $125.859^{227}$ ). Ressalta-se que a mesma posição já havia sido adotada em antigo acórdão do STF, o RE $109.097^{228}$.

Mais recentemente, tal entendimento foi repetido no âmbito do REsp $742.048^{229}$, em que ficou consignado que "a promessa de doação feita aos filhos por seus genitores como condição para a obtenção de acordo quanto à partilha de bens havida com a separação ou divórcio não é ato de mera liberalidade e, por isso, pode ser exigida, inclusive pelos filhos, beneficiários desse ato".

Em sentido semelhante, recusando a natureza de "promessa de doação" àquelas promessas realizadas "no bojo de acordos de separação de casais homologados judicialmente", o Min. Jorge Scaterzzini, relator do REsp $730.626^{230}$, consignou que "tais disposições não caracterizam propriamente uma promessa de doação, vez que não há ato de liberalidade".

${ }^{222}$ Cf. J. B. Villela, Contrato de doação cit., pp. 268-69 e 271. O autor não exclui, porém, "que o beneficiente não possa vir a ser responsabilizado pela sua conduta prévia capaz de ofender a boa-fé objetiva".

${ }^{223}$ Cf. D. A. CARNAÚBA - G. H. L. ReINIG, Nulidade da doação e conversão substancial do negócio jurídico cit., p. 407.

${ }^{224}$ Cf. STJ, $3^{\text {a }}$ Turma, REsp 23.507-SP, Rel. Min. Nilson Naves, j. 26.04.1993.

${ }^{225}$ Cf. STJ, 4 a Turma, REsp 30.647-RS, Rel. Min. Barros Monteiro, j. 23.11.1998.

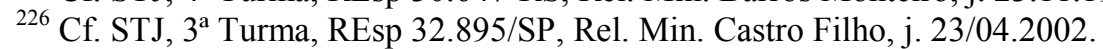

${ }^{227}$ Cf. STJ, $2^{\text {a }}$ Seção, EREsp 125.859/RJ, Rel. Min. Ruy Rosado de Aguiar, j. 26.06.2002.

${ }^{228}$ Cf. STF, $1^{\text {a }}$ Turma, RE 109.097/RS, Rel. Min. Octavio Gallotti, j. 09.09.1986.

${ }^{229}$ Cf. STJ, $3^{\text {a }}$ Turma, REsp 742.048-RS, Rel. Min. Sidnei Beneti, j. 14.04.2009.

${ }^{230}$ Cf. STJ, $4^{\mathrm{a}}$ Turma, REsp 730.626-SP, Rel. Min. Jorge Scartezzini, j. 17.10.2006. 
Segundo o voto, "o compromisso de transferir a propriedade objetiva, na hipótese, contraprestação", pois "não há o ânimo de bem fazer, estão as partes imbuídas do desejo de obter vantagens recíprocas, consistente na aquiescência do outro cônjuge à dissolução da sociedade conjugal, à concretização de uma separação consensual e mais célere". Por essa razão, a chamada promessa de doação "se admite unicamente nos casos referidos, em que há verdadeira transação e não ato de liberalidade”.

Ampliando um pouco mais tal entendimento, de modo a abranger a transação em geral, o Enunciado 549, aprovado na VI Jornada de Direito Civil do Centro de Estudos Judiciários do Conselho da Justiça Federal, sugeriu que "a promessa de doação no âmbito da transação constitui obrigação positiva e perde o caráter de liberalidade previsto no art. 538 do Código Civil”.

A justificativa para tanto é que seria inegável o fato de que a promessa “expressa vontade negocial e, no âmbito da autonomia, não é sustentável restringir tal possibilidade somente aos negócios bilaterais comutativos e onerosos”. Seria, portanto, "legítimo cogitar-se de promessa de cumprir liberalidade que, após a chancela estatal, deixa de apresentar tal caráter" 231 .

Nota-se, entretanto, uma discrepância entre o enunciado e a justificativa. O enunciado dá a entender que toda transação admite a promessa de doação. Porém, a transação, conforme dispõe o art. 842 do CC br., pode ser extrajudicial: "por escritura pública, nas obrigações em que a lei o exige, ou por instrumento particular, nas em que ela o admite". A menção à "chancela estatal" feita na justificativa parece ter em vista a transação judicial, por meio da homologação pelo juiz. Fica a dúvida sobre se o teor do enunciado abrange também a transação extrajudicial.

Esse entendimento mais amplo foi adotado no REsp $853.133^{232}$, embora a qualificação do caso concreto como promessa de doação não tenha ficado absolutamente explícita $^{233}$. Trata de caso de cessão de direitos hereditários feita pelos filhos do de cujus

${ }^{231}$ Cf. R. RosAdo DE AgUIAR Jr. (coord.), Enunciados aprovados na VI Jornada de Direito Civil, Brasília, Centro de Estudos Judiciários do Conselho da Justiça Federal, 2013, disponível em http://www.cjf.jus.br/cjf/CEJ-Coedi/jornadas-cej/vijornada.pdf [acesso em 15 de agosto de 2015].

${ }^{232}$ Cf. STJ, $3^{\text {a }}$ Turma, REsp 853.133-SC, Rel. Min. Humberto Gomes de Barros, Rel. para o acórdão Min. Ari Pargendler, j. 06.05.2008.

${ }^{233}$ Cf. I.6.3. 
em favor da viúva-meeira, que, por sua vez, comprometeu-se a transferir bens móveis e imóveis para seus filhos.

O Relator Min. Humberto Gomes de Barros entendeu que não houve promessa de doação, mas verdadeira contraprestação à cessão realizada. Em voto-vista, o Relator para o acórdão Min. Ari Pargendler foi mais categórico ao afirmar tratar-se de promessa de doação, mas ressaltou que esta foi "o meio pelo qual as partes da chamada 'transação' viabilizaram a partilha dos bens entre os herdeiros; foi, portanto, condição do negócio, e não mera liberalidade". De todo modo, trata-se de reconhecimento absolutamente excepcional pelo STJ, que permanece refratário, em regra, à admissibilidade da promessa de doação.

Entre os julgados mais recentes, o já referido REsp $730.626^{234}$ tratou de caso em que uma parte se comprometeu a doar parcela de imóvel, pendente de "regularização acerca da propriedade". O STJ entendeu que não se tratava de doação sujeita a condição, mas de promessa de doação, pois não estariam presentes os "elementos do contrato principal". Não haveria um "contrato findo, acabado", mas um acordo cujo "objeto central" seria a "realização de futuro contrato".

De acordo com o voto vencedor ${ }^{235}$, embora, em princípio, não houvesse "empecilho" à "admissão de um contrato preliminar pelo qual" uma parte "se compromete a no futuro firmar um contrato de doação", esta "conclusão apriorística se olvida de elemento essencial da doação, o animus donandi". A “intenção do doador de praticar um ato de liberalidade" seria "requisito indispensável para configuração do contrato de doação".

Se "o contrato de doação encerra elementos subjetivo e objetivo", não se pode prescindir do primeiro, o "animus donandi, o ato de liberalidade, a vontade de doar, de bem fazer". É verdade que a "intenção de efetivar a doação futura" está presente no

${ }^{234}$ Cf. STJ, 4a Turma, REsp 730.626-SP, Rel. Min. Jorge Scartezzini, j. 17.10.2006.

${ }^{235} \mathrm{O}$ referido recurso não teve votação unânime, mas o voto-vencido do Min. Hélio Quaglia Barbosa não contrariou a fundamentação jurídica adotada pelo Relator. O voto simplemente deu qualificação jurídica diversa ao negócio celebrado entre as partes. Segundo o Ministro, "o negócio jurídico que originou a presente ação de cobrança não cuida de uma promessa de doação, conforme qualificação jurídica conferida pelo Tribunal de origem; trata-se, em verdade, de contratos simultâneos com obrigações recíprocas, contidas em dois negócios jurídicos celebrados pelas partes”, cf. STJ, 4a Turma, REsp 730.626-SP, Rel. Min. Jorge Scartezzini, j. 17.10.2006. 
momento de celebração do contrato preliminar, mas "não há como se afirmar com tal certeza" que no momento da celebração do contrato "subsistirá a livre determinação do doador de efetivar o ato de liberalidade".

Para o Min. Jorge Scaterzzini, "se não há espontaneidade no ato de doar no momento da celebração do contrato definitivo, não pode ocorrer o contrato", pois "a atualidade do animus donandi é basilar à efetivação da doação". O acórdão conclui "pela total inoperância da promessa de doação, posto que, como ato de liberalidade, é incompatível com a execução forçada, sendo sempre viável o arrependimento ou a revogação".

Para o STJ, assim, a promessa de doação "é retratável a todo tempo antes da definitiva doação, o que acaba por despi-la da exigibilidade típica do vínculo contratual". O voto vencedor afirma ainda: "admitir a promessa de doação equivale a concluir pela possibilidade de uma doação coativa, incompatível, por definição, com um ato de liberalidade. Supor que na impossibilidade do cumprimento de uma obrigação assumida por liberalidade teríamos sua conversão em perdas e danos fere de morte a natureza gratuita do contrato de doação. A atualidade na manifestação da vontade de bem fazer é conditio sine qua non ao contrato de doação".

O que se pode ver, da análise desses acórdãos, é que a exclusão da admissibilidade da promessa de doação funda-se essencialmente na ausência de animus donandi $^{236}$, seja entendido em seu sentido objetivo, seja em seu sentido subjetivo ${ }^{237}$. Sendo o animus donandi, no entendimento desses julgados, um requisito essencial para a doação, as exceções à vedação do contrato preliminar não são propriamente exceções, pois se exclui a qualificação do negócio como "mera liberalidade". A vedação para a doação como "pura liberalidade", digamos, permanece hígida.

Embora o STJ entenda que a promessa de doação é inadmissível, na doutrina é digna de nota a posição de autores cujo entendimento vai no sentido diametralmente

${ }^{236}$ Nesse sentido, criticamente, cf. M. C. BODIN DE MORAES, Notas sobre a promessa de doação cit., pp. 2-3.

${ }^{237}$ Esses sentidos de animus donandi serão vistos em III.3.1 e III.3.2. O referido voto do Min. Jorge Scaterzzini não faz uma opção nítida, ora falando em "ânimo de bem fazer" (sentido subjetivo), ora em "espontaneidade" (sentido objetivo). 
oposto. São favoráveis à promessa de doação, por exemplo, PONTES DE MiRANDA ${ }^{238}$, LÔBO $^{239}$, Nery e PENTEAdo ${ }^{240}$ e BODIN DE MORAEs, que dedicou artigo especificamente ao tema. Para esta última autora, se o respeito aos compromissos assumidos é um dos objetivos do ordenamento, não há razão para que se exclua a obrigação de o doador respeitar a palavra dada ${ }^{241}$.

Além disso, o CC de 2002 regulou expressamente o contrato preliminar, sem excepcionar a doação. Em se tratando de contrato preliminar, deve-se reconhecer que na contratação definitiva está sempre ausente "a plena liberdade de se obrigar", pois "ela já foi exercida quando da contratação da promessa". Não há razão para se falar em "doação coativa", pois o promitente-donatário manifestou sua vontade livremente no momento da declaração, tanto mais porque a hipótese de arrependimento é expressamente disciplinada no CC de $2002^{242}$.

\section{Contrato consensual e contrato preliminar de doação}

Um problema conexo à admissibilidade ou não do contrato preliminar de doação é sua diferença em relação ao contrato consensual de doação. Segundo VILLELA, 229 , principalmente.

${ }^{238}$ Cf. F. C. PONTES DE MIRANDA, Tratado de direito privado XLVI cit., passim e pp. 201-02 e

${ }^{239}$ Cf. P. L. N. LôBo, Comentários ao Código Civil VI cit., pp. 284-86. gestão cit., pp. 33-34.

${ }^{40}$ Cf. N. NeRY Jr. - L. C. PenteAdo, Doação pura, preliminar de doação e contratos de

${ }^{241}$ Cf. M. C. BODIN DE MORAES, Notas sobre a promessa de doação cit., p. 13. Para a jurista, a concepção de que o doador pode mudar de ideia a qualquer momento relaciona-se com uma preponderância excessiva da "vontade". Esse dogma, embora embase a livre prática de uma vasta gama de atos, leva à rejeição de outros, supostamente contrários à "autonomia da vontade". Com a valorização da solidariedade contratual e social e da dignidade da pessoa humana, além da boa-fé, ganhariam importância a proteção à legítima expectativa do donatário e o correspondente dever de lealdade e probidade do doador.

${ }^{242}$ Cf. M. C. BODIN DE MORAES, Notas sobre a promessa de doação cit., pp. 12-13 e 17-18. Dispõe, com efeito, o art. 463 que "qualquer das partes terá o direito de exigir a celebração do definitivo" desde que dele "não conste cláusula de arrependimento". No mesmo sentido, para NERY e PENTEADO, está superado o pensamento de que a promessa de doação implicaria doação contra voluntas, ferindo a exigência da liberalidade ou animus donandi, pois a liberalidade já é manifestada no contrato preliminar, cf. N. NERY Jr. - L. C. PenteADO, Doação pura, preliminar de doação e contratos de gestão cit., pp. 33-34. Discussão semelhante se coloca no direito italiano, com relação à admissibilidade ou não do contrato preliminar de doação. Argumentos contrários fundam-se na suposta ausência de espontaneidade no contrato definitivo, o que implicaria a incompatibilidade deste com o espírito de liberalidade. Outro argumento é no sentido de que a obrigação de contratar o definitivo seria uma obrigação de fazer, tida por alguns como incompatível com o contrato de doação. Por outro lado, há quem diga que o requisito da espontaneidade já é manifestado no contrato preliminar, sendo desnecessária sua presença no definitivo, cf. R LENZI, Donazione obbligatoria cit., pp. 1635-36. 
mostra-se contraditório que autores considerem o contrato de doação consensual, mas não admitam a promessa de doação. Se no contrato consensual o doador obriga-se a transferir o bem ao donatário, ele é "exatamente uma promessa, um pactum de donando". Por outro lado, se há promessa de doação e esta é um contrato real, a transferência do bem será “execução da promessa ou execução da doação?"243.

No AgRg no REsp 883.232 244 , por exemplo, não fica evidente se a hipótese dos autos é promessa de doação ou doação propriamente dita. Trata-se de caso em que foi estabelecido no acordo judicial de separação a doação de bens particulares do genitor à única filha do casal. O pai alegou que não era obrigado a cumprir o acordo, pois a doação não havia sido formalizada pelo registro. Alegou ainda que a superveniência de três filhos, concebidos em data posterior ao acordo celebrado, levaria a doação a atingir a legítima dos herdeiros necessários.

Embora o Relator Min. Raul Araújo tenha invocado a jurisprudência do STJ que admite a promessa de doação caso seja estabelecida no acordo judicial de separação, no decorrer de seu voto cuidou do caso como se de doação se tratasse, habilmente evitando qualificar expressamente o negócio como contrato preliminar.

Por um lado, ressaltou que "não se caracteriza como ato de mera liberalidade ou simples promessa de doação, passível de revogação posterior, a doação feita pelos genitores aos seus filhos estabelecida como condição para a obtenção de acordo em separação judicial". Por outro lado, afirmou que "o contrato de doação foi aperfeiçoado no momento em que houve a aceitação da doação do patrimônio do genitor, ficando, portanto, perfeitamente executável eventual descumprimento do donatário em cumprir sua obrigação" 245 . O ministro parece reconhecer um contrato consensual de doação, mas valeu-

${ }^{243}$ Cf. J. B. VillelA, Contrato de doação cit., pp. 265-66. Criticamente, sobre a possibilidade de se entender que o contrato preliminar de doação seria, ele próprio, doação, cf. R. LENZI, Donazione obbligatoria cit., p. 1641.

${ }^{244}$ Cf. STJ, 4 a Turma, AgRg no REsp 883.232-MT, Rel. Min. Raul Araújo, j. 19.02.2013.

${ }^{245}$ Em seu voto, por sua vez, a Min. Maria Isabel Gallotti expressamente qualificou o negócio como doação e determinou a aplicação do critério do art. 549, segundo o qual o valor da doação inoficiosa corresponde "à parte que exceder à de que o doador, no momento da liberalidade, poderia dispor em testamento". Consignou, ainda, que "a circunstância de haver filhos concebidos posteriormente à doação não a invalida, porque, de acordo com o disposto no Código Civil, o valor dos bens a serem doados em relação ao patrimônio há de ser considerado na data em que feita a doação". 
se da jurisprudência construída acerca do preliminar. É exatamente um exemplo do fenômeno denunciado por VILLELA.

Sobre a questão, PONTES DE MIRANDA afirma que "promessa de doação" pode ser entendida tanto como "promessa de contrato de doação" - isto é, contrato preliminar quanto como "contrato consensual de doação". Como visto, o autor entende que a doação é contrato real, como regra, e excepcionalmente consensual ${ }^{246}$, e entende admissíveis tanto o contrato preliminar de doação real, quanto o preliminar de doação consensual. Dessa forma, a doação em forma de subvenção periódica - art. 545, antigo art. 1.172 - pode ser celebrada tanto na forma de doação consensual quanto de promessa de doação, pois se trata de ius dispositivum ${ }^{247}$.

Para o autor, a diferença entre a doação consensual e o contrato preliminar é feita com base na eficácia, pois se no contrato preliminar o doador não é o dono do bem a ser doado, não tem o dever de adquiri-lo, cabendo ao donatário somente "a ação de indenização por inadimplemento". Isso ocorre porque "o promitente vincula-se a fazer o contrato de doação, não a prestar o bem". Ao contrário, no caso do contrato consensual de doação, aquele que "promete o bem" tem "o dever de adquiri-lo, ou de obter do terceiro que satisfaça a dívida assumida"248.

A diferença, porém, só faz sentido até certo ponto. Embora a introdução do art. 461-A no CPC tenha consagrado definitivamente a possibilidade da execução específica das obrigações de entrega de coisa, o fato é que em caso de absoluta impossibilidade do objeto da prestação, invariavelmente haverá resolução em perdas e danos, o que diminui importância da distinção prática entre o contrato preliminar e o definitivo.

O BGB simplifica a questão, ao estabelecer simplesmente a dicotomia entre doação e promessa de doação. Aquela é simplesmente uma atribuição, sem exigência de forma especial, mediante a qual uma parte enriquece outra à custa de seu patrimônio,

${ }^{246}$ Cf. I.6.1.

${ }^{247}$ Cf. F. C. Pontes DE MIRANDA, Tratado de direito privado XLVI cit., pp. 201, 204 e 229. Também no sentido de que a doação do art. 545 pode ser entendida como uma promessa de doações reais periódicas, cf. L. C. PENTEADO, Doação com encargo e causa contratual cit., p. 314.

${ }^{248}$ Cf. F. C. PONTES DE MIRANDA, Tratado de direito privado XLVI cit., p. 261. 
exigindo também um acordo de ambas as partes quanto à gratuidade ${ }^{249}$. Já a promessa deve ter forma solene e seu cumprimento é exigível pelo donatário ${ }^{250}$, salvo se o adimplemento colocar em perigo a subsistência do doador ou o adimplemento de obrigação alimentar imposta por $1 \mathrm{ei}^{251}$.

Uma disciplina semelhante foi proposta na França por CARBONNIER e sua equipe $^{252}$, mas não foi incorporada ao Code civil. A proposta incluiria dispositivo expressamente reconhecendo a validade da promessa de doação ${ }^{253}$, desde que realizada perante o notário ${ }^{254}$. Haveria ainda a possibilidade de revogação da promessa, mediante pagamento de indenização, salvo no caso de justo motivo 255 .

Em que pese a posição de parte considerável da doutrina e jurisprudência, a nós parece bastante razoável admitir que o doador (ou o promitente doador) possa ser obrigado a cumprir a obrigação assumida, seja através de um contrato consensual de doação, seja através de um contrato preliminar de doação. O pretexto de se preservar a sua "vontade", com suas possíveis alterações e caprichos, contraditoriamente parece consagrar uma concepção muito restrita e limitadora da autonomia privada e da liberdade

${ }^{249}$ A doação é definida no $\$ 516$ do BGB: “(1) Una attribuzione, mediante la quale un arricchisce un altro a carico del suo patrimonio, è donazione se entrambe le parti sono d'accordo che l'attribuzione si realizzi gratuitamente. (2) Se la attribuzione si realizza senza la volontà dell'altro, il disponente può intimargli, con fissazione di un termine adeguato, di dichiararsi sull'accettazione. Dopo il decorso del termine la donazione vale come accettata se l'altro non l'ha rifuitata prima. In caso di rifiuto può essere pretesa la restituzione di ciò che è stato attribuito secondo le disposizioni sulla restituzione dell'ingiustificato arricchimento", cf. S. PATTI (org.), Codice civile tedesco cit., p. 313.

${ }^{250}$ A regra está no 5518 : “(1) Per la validità di un contratto con il quale una prestazione è promessa a titolo di donazione è necessaria la certificazione notarile della promessa. Lo stesso vale per la promessa o per la dischiarazione di riconoscimento se una promessa di debito o una ricognizione di debito del tipo indicato nei $\S \S 780$ e 781 è rilasciata a titolo di donazione. (2) Il difetto di forma è sanato con l'esecuzione della prestazione promessa", cf. S. PATTI (org.), Codice civile tedesco cit., p. 313.

${ }^{251}$ Nesse sentido, o doador pode ser obrigado a cumprir a obrigação, salvo no caso da "Eccezione dello stato di bisogno", prevista no $\S 519,(1)$ : "Il donante è legittimato a rifiutarsi di adempiere una promessa rilasciata a titolo di donazione se egli, con riguardo ad altre sue obbligazioni, non sia in grado di adempiere la promessa senza che venga messo in pericolo il suo adeguato mantenimento o l'adempimento degli obblighi alimentari che gli incombono per legge". O BGB também prevê a "Restituzione in caso di impoverimento del donante", no $§ 528$, que é excluída nos casos do $\$ 529$ ("Esclusione delle pretesa di ripetizione, cf. S. PATTI (org.), Codice civile tedesco cit., p. 313.

${ }^{252}$ Cf. J. CARBonnier et al., Des libéralités cit., p. 48.

253 Art. 936. La promesse de donation est valable.

${ }^{254}$ A primeira parte do art. 937 teria a seguinte redação: La promesse est faite devant notaire en présence du bénéficiaire qui l'accepte en tant que promesse.

${ }^{255}$ Art. 939. Le promettant peut révoquer sa promesse sauf à réparer le préjudice éventuellement causé au bénéficiaire à moins qu'il ne prouve un juste motif de révocation.

A proposta de lei não foi aceita, todavia, talvez porque naquele país, como visto, a doação sempre foi concebia em sua modalidade in dando e até hoje é forte o entendimento de que a promessa é inadmissível, cf. R. HYLAND, Gifts cit., p. 319. 
contratual $^{256}$, contrariando os princípios do consensualismo e da força obrigatória dos contratos (pacta sunt servanda $)^{257}$.

TEIXEIRA DE FREITAS, aliás, previu expressamente a possibilidade de cumprimento forçado da obrigação do doador em seu Esboço. O art. 2.160 dispunha: "Fica obrigado o doador, que não tiver feito tradição da coisa doada, a entregá-la ao donatário com os frutos desde a mora, sendo porém, considerado como um possuidor de boa-fé". Além disso, a doação consensual vem sendo adotada expressamente em construções estrangeiras mais recentes, como o CC peruano de $1984^{258}$. O Draft Common Frame of Reference, assim como o CC italiano de 1942, admite tanto a doação real quanto a consensual, e, ao contrário do entendimento de PONTES DE MiRANDA, a consensual é a regra e a real a exceção ${ }^{259}$.

Com relação ao contrato preliminar de doação, por não estar disciplinado expressamente no nosso direito, coloca-se a questão acerca de sua forma. Para PENTEADO, a promessa de doação deve ser feita através de um vestimentum, em linha com sua teoria que vê a forma prescrita em lei como uma maneira de suprir a ausência de causa na doação ${ }^{260}$. Seria por essa razão, aliás, que o STJ seria mais flexível no reconhecimento da

${ }^{256}$ A liberdade contratual é uma especificação da autonomia privada para o campo dos contratos. A autonomia privada é a "faculdade reconhecida aos particulares de fixarem livremente, segundo o seu critério, a disciplina vinculativa de seus interesses, nas relações com as demais critaturas". A liberdade contratual é "o poder reconhecido às pessoas de estabelecerem, de comum acordo, as cláusulas reguladoras (no plano do Direito) dos seus interesses contrapostos". A autonomia privada é mais ampla, pois compreende outras liberdades, como a de associação, de tomar deliberações em órgãos colegiados, de testar, de celebrar acordos que não são contratos e de praticar negócios jurídicos unilaterais, cf. J. M. ANTUNES VARELA, Das obrigações em geral I cit., pp. 226-27.

${ }^{257}$ ANTUNES VARELA relaciona o princípio da força obrigatória dos contratos e a legítima expectativa gerada nas partes contratantes com o princípio da confiança, cf. J. M. ANTUNES VARELA, Das obrigações em geral I cit., p. 227. A confiança é definida por MENEZES CORDEIRO como "a situação em que uma pessoa adere, em termos de atividade ou de crença, a certas representações, passadas, presentes ou futuras, que tenha por efetivas". O "princípio da confiança explicitaria o reconhecimento dessa situação e a sua tutela", aproximando-se da ideia de boa-fé, cf. A. M. R. MENEZES CORDEIRO, Da boa fé no direito civil, $3^{\mathrm{a}}$ reimpr. (1983), Coimbra, Almedina, 2007, p. 1235.

${ }^{258}$ Art. $1621^{\circ}$. Por la donación el donante se obliga a transferir gratuitamente al donatario la propriedade de un bien.

${ }^{259}$ De acordo com IV.H. - 1:101, "a contract for the donation of goods is a contract under which one party, the doner, gratuitously undertakes to transfer the ownership of goods to another party, the donee, and does so with an intention to benefit the donee". Todavia, "this part of the definition does not exclude judicial acts under which ownership is immediately transferred to the donee, where it could be argued that no obligation is created at all as the judicial act connotes only a justification for an enrichment", cf. C. BAR - E. Clive (coord.), Principles, Definitions and Model Rules of European Private Law III - Draft Common Frame of Reference (DCFR) - Full Edition, Munich, Sellier, 2009, p. 2799.

${ }^{260}$ Cf. III.4.1. 
promessa de doação em um "contexto especial", como "nos processos judiciais de separação", pois "o âmbito em que é expedida a declaração supre a veste”"261.

É verdade que o art. 462 não exige, para o contrato preliminar, os requisitos de forma exigidos para o contrato definitivo. Nesse sentido, o novo CC abandonou o "princípio da pariformidade" mencionado por ERPEN, segundo o qual "quando o contrato definitivo exigir forma solene, os atos preliminares e os preparatórios também devem guardar tal solenidade" ${ }^{262}$. Todavia, parece realmente ser razoável que se exija para o contrato preliminar a mesma forma prescrita em lei para a doação. Isso não se deve em razão de a doação aproximar-se dos negócios abstratos, ou a forma ser elemento de existência, como afirmará certa corrente teórica ${ }^{263}$. Deve-se principalmente ao fato de que, como visto, a doação consensual e o contrato preliminar sejam muito difíceis de distinguir na prática. Convém, em razão disso, adotar-se a exigência de forma escrita. Era, aliás, o que entendia PONTES DE MIRANDA em relação ao Código antigo: "no direito brasileiro a promessa de doar só exige forma escrita; não a escritura pública. O art. 1.168 do Código Civil [de 1916], referente à doação, também incide quanto às promessas de doar (précontrato de doação)"264.

${ }^{261}$ Cf. L. C. PENTEADO, Doação com encargo e causa contratual cit., pp. 291-92.

${ }^{262}$ Cf. D. A. ERPEN, Da promessa de doar nas separações judiciais, in $R T 77$ (1988), pp. 2223.

${ }^{263}$ Cf. III.4.1. e III.4.2.

${ }^{264}$ Cf. F. C. PONTES DE MIRANDA, Tratado de direito privado XLVI cit., p. 242. O CC port., aliás, em seu art. $410^{\circ}, 2$, estabelece, em relação ao "contrato-promessa", que "a promessa respeitante à celebração de contrato para o qual a lei exija documento, quer autêntico, quer particular, só vale se constar de documento assinado pela parte que se vincula ou por ambas, consoante o contrato-promessa seja unilateral ou bilateral". 


\section{Críticas à disciplina jurídica da doação}

\section{Críticas à estrutura contratual da doação}

O fato de que a posição legislativa prevalente, em diversos ordenamentos, seja no sentido de estruturar a doação como contrato, não significa, todavia, que críticas relevantes não sejam feitas a essa concepção. VILLELA, aliás, aponta a existência de uma tese (à qual não tivemos acesso), publicada em Recife no ano de 1947, "cujo título era a própria negação do caráter contratual da doação: Doação não é Contrato"265.

As críticas centram-se em dois pontos: a possibilidade de a doação ser uma categoria geral e não um negócio específico, e a ideia de que a doação exprime uma operação essencialmente unilateral. É interessante notar que a primeira crítica colhe traços da doação como causa no direito romano, e a segunda da doação como disciplinada no direito francês, ao lado do testamento.

Um ponto de partida recorrente para a primeira é o pensamento de SAVIGNY, para quem a doação não é um negócio jurídico singular, mas "un carattere generale, che può riscontrarsi nei negozi giuridici più svariati”. Por essa razão, a doação estaria na parte geral, ao lado do contrato, "al quale essa è simile per la generalità della sua natura e per la molteplicità delle sue applicazioni”. A transmissão da propriedade não é a única forma de efetuar doação. Esta poderia ser feita através do usufruto, da enfiteuse, de uma simples promessa contratual ou da liberação de uma obrigação ${ }^{266}$.

Falar-se-á, mais adiante, acerca das doações indiretas: se devem ser abrangidas pelo conceito de doação, ou se devem ser tratadas como liberalidades diversas. São figuras que, contratuais ou não - como renúncia, adimplemento por terceiro não interessado, remissão de débito, cessão gratuita de crédito, assunção gratuita de dívida, estipulação em favor de terceiro e construções e plantações em terreno alheio, por exemplo -, embora muitas vezes contem com um regime jurídico próprio, podem produzir resultado jurídico análogo ao da doação, inclusive no que se refere à repercussão no direito das sucessões.

${ }^{265}$ Cf. J. B. Villela, Contrato de doação cit., pp. 250-51 e nt. 4. O autor da referida tese, defendida para a obtenção da cátedra em Direito Civil, teria sido Nestor Diogenes, desembargador do Tribunal de Justiça de Pernambuco.

${ }^{266}$ Cf. F. C. SAVIGNY, System des heutigen römischen Rechts, trad. it. V. Scialoja, Sistema del diritto romano attuale $I V$, Torino, UTET, 1889, pp. 3-4. 
Por essa razão, PENTEAdo indica a possibilidade de conceber-se a doação como figura e não como instituto. Como "figura jurídica multifuncional”, a doação seria "uma moldura que se presta a diferentes papéis e que sofre diferentes funções", tais como produzir adiantamento da legítima, sustentar alguém necessitado (art. 545) ou operar o "adimplemento de pretensões ou direitos mutilados". Seria, dessa forma, uma "categoria genérica e abstrata", que conjuga características contratuais com outras, mais semelhantes a um "gênero ou modo de aquisição", o que nos lembra a posição de SAVIGNY de que é "instituto da parte geral”267. BIONDI, aliás, já afirmava que a doação possui esse caráter “tentacular", abrangendo vários campos da atividade patrimonial ${ }^{268}$.

Outra crítica é no sentido de que a doação se assemelharia aos negócios unilaterais, especialmente ao testamento ${ }^{269}$, o que se verifica a partir da própria lei: o fato de que seja um mecanismo para adiantamento da legítima dos herdeiros necessários (arts. 544 e 2.003, parágrafo único), de que os bens adquiridos "por doação ou sucessão" sejam tratados da mesma forma no regime da comunhão parcial ("excluem-se da comunhão" art. 1.659, I) e a possibilidade de imposição de encargo (arts. 136 e 137) e cláusulas de inalienabilidade, incomunicabilidade e impenhorabilidade (aos "atos de liberalidade" - art. 1.911) são exemplos disso.

BETTI, ao tratar da interpretação dos negócios jurídicos, aponta uma diferença fundamental, quanto ao ponto de relevância hermenêutica, entre os negócios jurídicos inter vivos e mortis causa. E essa diferença está relacionada ao fato de que, enquanto a função econômico-social dos negócios inter vivos destina-se à composição de um conflito de interesses, a função dos negócios mortis causa destina-se à criação de uma vinculação sucessória entre o de cujus e os beneficiários ${ }^{270}$.

${ }^{267}$ Cf. L. C. PENTEAdO, Doação com encargo e causa contratual cit., pp. 310-11 e 317-21.

${ }^{268}$ Cf. B. BIONDI, Le donazioni cit., pp. 3 e 8-10. A ideia expressa no texto guarda alguma relação com a afirmação de BIANCA de que a liberalidade - note-se, não a doação - é um "tipo contratual geral" que reflete "exigências gerais" da "vita di relazione", cf. C. M. BIANCA, Diritto civile III - Il contratto, $2^{\mathrm{a}}$ ed., Milano, Giuffrè, 2000, p. 487.

${ }^{269}$ No sentido da ambiguidade da caracterização da doação, afirmava EsPínOLA que "é uma liberalidade, como o é a disposição testamentária, mas é, ao mesmo tempo, um contrato como qualquer outro", cf. E. EsPínOla, Dos contratos nominados no direito civil brasileiro, Rio de Janeiro, Gazeta Judiciária, 1953, p. 144. Também cf. A. V. ItABAiAna De OliveirA - A. ITABAiana de OliveirA, Tratado de direito das sucessões II - Da sucessão testamentária, 4ª ed., São Paulo, Max Limonad, 1952, p. 639.

${ }^{270}$ Cf. E. BETTI, Teoria generale del negozio giuridico cit., p. 331. Em sentido contrário, para BODIN DE MORAES, a doação deve ser concebida não como um ato de favor, generosidade ou benemerência, 
No que se refere à doação, parece realmente que sua função tenha mais relação com a criação de um vínculo jurídico análogo ao sucessório. É nesse sentido que CHAMOUN chama atenção para a "natureza excepcional" da doação, que, ao contrário de "todos os outros contratos", não exprime "interesses contraditórios, ou egoísticos, próprios do 'bügerliches Recht", mas é "uma liberalidade, uma gratuidade, a que falta o do ut des peculiar a outros contratos, um prêmio em princípio desinteressado com que o doador distingue e contempla o donatário" ${ }^{, 271}$.

FERRI, aliás, chega a afirmar explicitamente que falta na doação a "comune composizione di opposti interessi”. Esse autor destaca que a configuração da doação como um contrato é resultado de uma escolha do legislador quanto à estrutura, mas isso não apaga o fato de que a doação exprime sempre uma operação unilateral do ponto de vista econômico $^{272}$. Nesse sentido, PONTES DE MIRANDA, em seu modo peculiar de escrever, afirma que o interesse do doador existe, mas não "está" - ele "subestá" (no sentido de ser secundário $)^{273}$. E esse caráter economicamente unilateral condiciona a própria disciplina legislativa.

Para FERRI, é exemplo disso a existência de regras mais flexíveis quanto à aceitação. No caso brasileiro, trata-se da dispensa no caso do donatário absolutamente incapaz (art. 543), presunção no caso da doação para casamento (art. 546) e previsão da aceitação por meio do silêncio do donatário (art. 539), como foi visto ${ }^{274}$. Outra consequência é a possibilidade de revogação por ingratidão, através do exercício de direito potestativo atribuído ao doador ${ }^{275}$.

Para PenteAdo, a qualificação da doação, feita com base no caso concreto e em certa relevância da intuição, aponta um sentido diverso daquele adotado pelo art. 538

mas como um contrato - o que, aliás, é expressamente reconhecido pelo CC brasileiro. Nesse sentido, visa, como toda relação contratual, à harmonização dos interesses opostos dos contratantes, cf. M. C. BODIN DE MORAES, Notas sobre a promessa de doação cit., pp. 17-18.

${ }^{271}$ Cf. E. Chamoun, (parecer) Doações sujeitas a termo e condição. Invalidade de cláusula relativa à destinação dos bens após o termo e condição cit., p. 188.

${ }^{272}$ Cf. G. B. FERRI, Dall'intento liberale al cosiddetto impegno etico e superetico cit., pp. 2830.

${ }^{273}$ Cf. F. C. PONTES DE MiRAndA, Tratado de direito privado XLVI cit., pp. 231-33. Apesar disso, o autor não questiona a natureza contratual da doação, e afirma ser necessário o acordo entre o animus donandi do doador e o animus donum accipiendi do donatário.

${ }^{274}$ Cf. I.5.2.

30.

${ }^{275}$ Cf. G. B. FERRI, Dall'intento liberale al cosiddetto impegno etico e superetico cit., pp. 28- 
do CC. Parece aproximar-se de um negócio unilateral receptício ${ }^{276}$, no qual "a recepção pelo destinatário é fator de eficácia do negócio, e, portanto, algo a ele extrínseco, e não elemento que formalmente o constitui" ${ }^{\text {277 }}$. Esse posicionamento vai na linha de conferir uma importância menor ao consentimento do donatário na doação, que apenas aceita ou rejeita a atribuição, sem ter o poder de modificação do seu conteúdo, que é decidido pelo doador $^{278}$.

As duas ordens de críticas tratadas neste tópico devem ser consideradas relevantes, como guia ao intérprete e como crítica ao direito positivo. Mas tem razão BIONDI ao ponderar que é possível "dissertar ao infinito", sob a inspiração "do mais refinado e penetrante espírito crítico" sobre os conceitos em abstrato, mas, ao final, não se pode trabalhar no âmbito de uma "dogmática abstrata". O que importa e deve ser tomado por base é aquilo que um determinado ordenamento positivo entende por doação. O autor afirma que embora a doação exista como fenômeno social antes de se tornar um instituto jurídico, o fato é que recebe uma particular configuração da lei, de maneira que a ciência não pode sobrepor outra definição à definição legal ${ }^{279}$.

Embora a doutrina possa, com justiça, criticar as opções do legislador por reputá-las ilógicas ou inoportunas, a delimitação do conceito deverá ser feita conforme a fattispecie legal ${ }^{280}$. É nesse sentido que FERRI aponta que sob o CC de 1865, que definia a doação como ato, seria possível até cogitar de uma interpretação que a construísse em termos não contratuais. Hoje, com sua definição explícita como contrato, isso não é mais possível $^{281}$.

As definições doutrinárias servem como precedente histórico, para esclarecer a definição legal, ou até mesmo propor uma nova orientação, mas o papel da dogmática, efetivamente, deve ser analisar os elementos constitutivos da noção legal, isolando-a dos

${ }^{276}$ Cf. L. C. PENTEADO, Doação com encargo e causa contratual cit., pp. 310-11 e 317-21.

${ }^{277}$ Cf. A. JunQueIRA DE AZEVEDO, Negócio jurídico cit., p. 132.

${ }^{278}$ Cf. L. C. Penteado, Doação com encargo e causa contratual cit., pp. 310-11 e 317-21. Caso seja concebida como um negócio jurídico unilateral, deve ao menos existir a possibilidade de o beneficiário rejeitar o benefício, uma vez que não é "razoável impor a quem quer que seja um benefício contra sua vontade”, cf. J. M. ANTUNES VARELA, Das obrigações em geral I cit., p. 438. Cf. I.5.2.

${ }^{279}$ Cf. B. BIONDI, Le donazioni cit., p. 10.

${ }^{280}$ Cf. G. DE Nova, Il tipo contrattuale, Padova, Cedam, 1974, pp. 70-78.

${ }^{281}$ Cf. G. B. FERRI, Dall'intento liberale al cosiddetto impegno etico e superetico cit., p. 25. 
fatos que não estão sujeitos à sua disciplina ${ }^{282}$. Assim, deve-se atentar para o fato de que o direito positivo (definição estipulativa) estrutura a doação como contrato e é dessa maneira que será tratada ao longo deste trabalho ${ }^{283}$.

\section{Complexidade e manutenção de regras por força da tradição}

Tornou-se lugar comum entre os autores italianos iniciar o estudo da doação com uma afirmação de BONFANTE, segundo a qual "le donazioni sono destinate a vagare come istituti in pena per le varie parti del sistema senza trovare requie in nessuna"284. HYLAND inicia seu estudo sobre as doações no direito comparado afirmando que "seria

${ }^{282}$ Cf. B. BIONDI, Le donazioni cit., pp. 87-88.

${ }^{283}$ Uma hipótese que parece ainda não ter sido explorada pela doutrina seria conceber a doação como um negócio jurídico bilateral que não seja contrato. O contrato é "o acordo vinculativo, assente sobre duas ou mais declarações de vontade (oferta ou proposta, de um lado; aceitação, do outro), contrapostas mas perfeitamente hamonizáveis entre si, que visam estabelecer uma composição unitária de interesses", cf. J. M. ANTUNES VARELA, Das obrigações em geral I cit., p. 212. Essa ideia implica a existência, nos contratos, de interesses contrapostos (embora "harmonizáveis"), que estariam ausentes na doação. A ideia nos foi gentilmente sugerida pelo Prof. João Alberto Schützer Del Nero em nossa banca de qualificação. O fato de ser negócio bilateral seria compatível com a necessidade de aceitação imposta pela lei. Além disso, chamaria atenção para o seu caráter "sui generis" (bem apontado pelos redadores do CC italiano) em relação aos demais contratos. Para MARTINS-COSTA, aliás, nos sistemas, como o brasileiro, que incluem a doação "na taxonomia contratual, há a qualificação necessária: "contrato sui generis". A autora assinala que "a doação é o único que vem nomeado especificamente como 'contrato', nenhum outro sendo indicado por esse qualificativo. Em outras palavras, a lei passa, desde logo, a assinalar os traços distintivos de cada um dos conceitos (compra e venda; locação; seguro; mandato etc.) sem a necessidade de dizer que se trata de um 'contrato', já estando as espécies arroladas no Título VI do Livro I da Parte Especial ('Das várias espécies de contrato'), cf. J. H. MARTINS-COSTA, O pacto no Sertão roseano - Os pactos, os contratos, o julgamento e a lei, in RIDB 2 (2013), pp. 5233-34 e nt. 13. A possibilidade de se entender que a doação não é contrato (mas outro negócio jurídico bilateral), contudo, no nosso modo de entender esbarra em dois impedimentos. $\mathrm{O}$ primeiro é o legislativo, pois o CC expressamente define a doação como contrato, conforme apontado. $\mathrm{O}$ segundo diz respeito ao fato de que o doador, na maior parte das vezes, também tem interesses na doação (cf. III.3.1 e III.5) - podendo até revogá-la nos casos legais, o que demostra que há algum grau de dever do donatário em relação ao doador - na linha do que afirmava MAUSS em seu estudo antropológico (cf. I.1). Isso talvez não permita vislumbrar a completa ausência daqueles interesses conflitantes característicos de um vínculo contratual. MARTINS-COSTA aponta que na doação há, certo, retribuição. O que falta é a contraprestação, no sentido de "reciprocidade proporcional" que é traço característico da justiça comutativa (p. 5234). PENTEAdo observa que a doação combina aspectos da justiça distributiva - ligada à "divisão proporcional dos bens para cada um dos membros da sociedade, em função de seu mérito e das suas necessidades" - com aspectos da justiça comutativa - "uma espécie da justiça corretiva e consiste na igualdade a se obter nas trocas voluntárias" - escapando à lógica binária que "se tornou uma constante no paradigma moderno". Por um lado, é um "ato de benfazer", "gratuito e personalíssimo, mediante o qual se atribui riqueza"; por outro, é contrato e concretiza parcialmente uma "tendência social de reciprocidade", como ressaltado por MAUSS, cf. L. C. PENTEAdO, Doação com encargo e causa contratual cit., pp. 297-303. Cf. M. P. C. B. MuÑoz, Justiça e contrato - Entre comutar e distribuir, Tese (Doutorado), São Paulo, Faculdade de Direito da Universidade de São Paulo, 2010, passim e p. 274, apresenta a liberalidade como um tertium genus, ao lado da justiça comutativa e distributiva.

${ }^{284}$ Por todos, cf. G. B. FERRI, Dall'intento liberale al cosiddetto impegno etico e superetico cit., p. 16. 
irresponsável não enfatizar que o direito que rege a prática de doações é um dos campos mais complexos do direito privado" 285 .

Vão nesse mesmo sentido afirmações de vários outros autores que estudam o tema. Para BIONDI, por exemplo, a doação talvez aparente ser o ato mais simples da vida comum, porque entendido intuitivamente como liberalidade, mas considerado sob o aspecto jurídico, torna-se um instituto árduo e difícil. O jurista destaca que a figura da doação não é simples nem homogênea. Ao contrário, é um dos atos mais complexos do direito privado, que apresenta dificuldades não encontradas em outros institutos ${ }^{286}$.

Entre os brasileiros, PONTES DE MIRANDA exprime "certa perplexidade diante do conceito de doação ${ }^{287}$. ALVIM pondera que não lhe "ocorre nenhum outro contrato que apresente tantas particularidades, ou originalidades, como a doação" ${ }^{288}$. VILLELA afirma que "em direito, tudo na doação é, a bem dizer, controvertido" e "reconhecer que a doação é uma figura embaraçosa para o direito pode ser o primeiro passo para se iniciar na sua intimidade" 289 . BODIN DE MORAES, igualmente, destaca que "todos os entendimentos são possíveis e todos igualmente insuficientes: a doação é um tema que desafia as mentes mais lúcidas e os pensamentos mais serenos" ${ }^{290}$.

Essa constatação generalizada dos autores é amparada pelo percurso que foi feito ao longo deste capítulo, em que foi visto como a doação - ao contrário de outros contratos, como a compra e venda - foi estruturada de maneiras muito diferentes em várias épocas e locais, e mesmo a prevalente concepção contratual não é isenta de críticas relevantes. O passo seguinte a essa constatação é a pergunta acerca do porquê dessa complexidade. Segundo HYLAND, é uma reação natural a pergunta sobre a razão de tantas regras terem sido criadas para regular algo em essência tão simples ${ }^{291}$.

${ }^{285}$ Cf. R. HYLAND, Gifts cit., p. 12: "it would be irresponsible not to enphasize at the outset that the law that governs gift giving is one of the most complicated fields in the private law".

${ }^{286}$ Cf. B. BIONDI, Le donazioni cit., pp. 3 e 8-11: "la donazione praticamente forse appare l'atto più semplice della vita comune, perché inteso intuitivamente come liberalità, ma, considerato sotto l'aspetto giuridico, diventa un istituto arduo e difficile".

${ }^{287}$ Cf. F. C. PONTES DE MIRANDA, Tratado de direito privado LXVI cit., pp. 192 e 198.

${ }^{288}$ Cf. A. AlviM, Da doação cit., p. 6.

${ }^{289}$ Cf. J. B. Villela, Contrato de doação cit., pp. 250 e 252, respectivamente.

${ }^{290}$ M. C. BODIN DE MORAES, Notas sobre a promessa de doação cit., p. 17.

${ }^{291}$ Cf. R. HYLAND, Gifts cit., p. 12. Não parece ter razão BIONDI ao atribui-la à extraordinária variedade de atos da vida tidos como doação e que como tal não são disciplinados pelo direito, como, no direito italiano, as liberalidades praticadas em conformidade aos usos, cf. B. BIONDI, Le donazioni cit., pp. 3 
Uma possível resposta estaria no fato de que a disciplina jurídica da doação seria resultado de uma estratificação milenar de regras muitas vezes contrastantes e contraditórias. Em tema de doação "si direbbe quasi che i secoli sono passati invano"292. Desde o tempo de Constantino, foi sendo depositado na disciplina jurídica um acúmulo de princípios e institutos que na legislação atual se encontrarim em estado de mistura amorfa. Cada época introduziu regras que, por força da inércia e da tradição, acabaram sendo repetidas pelas legislações atuais, ainda que hoje possa ser difícil encontrar justificativas para elas. Seriam fruto de considerações inveteradas e discutíveis considerações ${ }^{293}$.

As mudanças sociais fazem com que as palavras utilizadas pelas normas permaneçam em grande medida inalteradas. Há uma tendência conservadora - como a "concha do marisco abandonada" 294 - em se utilizar os mesmos velhos vocábulos em novas circunstâncias e para enfrentar novas questões. A consequência disso é que muitas vezes as normas sobrevivem aos seus propósitos ${ }^{295}$. Em tema de doação, o exemplo considerado mais significativo disso é a proibição da doação entre os cônjuges ${ }^{296}$.

Esta, que excepcionava apenas as liberalidades em conformidade com os usos, constava no art. 781 do CC italiano ${ }^{297}$, que foi posteriormente considerado

e 8-10. Se há uma diferença mais acentuada entre o sentido onomasiológico e o semasiológico da doação, isso parece ser mais consequência do que causa. O caminho parece ser outro.

${ }^{292}$ Cf. B. BIONDI, Le donazioni cit., p. 11. No mesmo sentido, HYLAND afirma ser notável acerca das doações que o direito que as disciplina coloca mais ou menos as mesmas questões há dois mil anos, cf. R. HYLAND, Gifts cit., p. 124.

${ }^{293}$ Cf. B. BIONDI, Le donazioni cit., pp. 9-10 e 15. FERRAZ Jr., sobre normas costumeiras, faz uma precisa afirmação que entendemos aplicável a determinadas normas sobre a doação: “o uso longo com o sentimento de obrigatoriedade instaura uma rede de disciplinas sem que possamos encontrar nelas alguma intenção", cf. T. S. FERRAZ Jr. Introdução ao estudo do direito cit., p. 292.

${ }^{294}$ Segundo MARTINS-COSTA, "especialmente no Direito Privado, as palavras e expressões designativas dos seus principais institutos podem ser metaforizadas pela concha do marisco abandonada: em uma concha jogada na areia da praia, o primitivo habitante que lhe recheava o conteúdo de há muito pode ter desaparecido e gerações de outros habitantes podem ali ter encontrado a sua morada. Traços do antigo morador, todavia, permanecem escondidos em suas volutas, incrustados e disfarçados em sua madrepérola, pontuando sutilmente nossas representações. Tal qual os habitantes da concha, os institutos jurídicos estão alojados em um universo de referências, algumas palpáveis e evidentes, outras muito habilmente escondidas por isso menos atuantes", cf. J. H. MARTINS-COSTA, A concha do marisco abandonada e o nomos (ou os nexos entre narrar e normatizar), in RIDB 2 (2013), pp. 4136-37.

${ }^{295}$ Cf. J. R. L. LOPES, As palavras e a lei cit., pp. 37-38 e R. HYLAND, Gifts cit., p. 75.

${ }^{296}$ Cf. III.1.1.

${ }^{297}$ O dispositivo, intitulado "Donazione tra coniugi", dispunha: "I coniugi non possono, durante il matrimonio, farsi l'uno all'altro alcuna liberalità, salve quelle conforme agli usi”. 
“constitucionalmente ilegítimo" pela Corte Constitucional em 27 de junho $1973^{298}$. A Exposição de Motivos do CC de 1942 narra que houve intensa discussão na elaboração do CC quanto à inclusão ou não da proibição. O projeto preliminar tratava a doação como válida, mas revogável; o definitivo a tratava como anulável. No texto final optou-se por manter a proibição.

A justificativa dada era no sentido de que a doação entre os cônjuges representava um "grave perigo" e não correspondia a uma exigência digna de tutela ${ }^{299}$, pois poderia turbar o regime da relação entre os esposos, que deveria basear-se no afeto e não em "egoistici calcoli utilitari”, sendo, portanto, necessária a sua proibição para manter íntegra a "solidariedade moral e material da família". Afirmou-se que a proibição não prejudicava a posição de prestígio da mulher em face do marido, pois estando os cônjuges em comunhão de vida, um fruiria dos bens do outro, e, para após a morte, cada um poderia dispor de seus bens em testamento em favor do sobrevivente ${ }^{300}$.

Em que pese essa argumentação, segundo BIONDI, a vedação não encontraria nenhuma justificativa plausível, sendo razoável entender que se tratasse de simples repetição das fontes romanas ${ }^{301}$. A proibição teria sobrevivido aos seus propósitos por dois milênios, pois a origem não estaria clara nem mesmo para os próprios jurisconsultos romanos, os quais, entretanto, imediatamente começaram a lhe atribuir propósitos, ainda que insuficientes e inconsistentes. Mesmo após a descoberta dos Fragmenta Vaticana, por meio dos quais se extrai que tais doações eram permitidas em um período anterior no direito romano - a Lex Cincia incluía os esposos justamente entre as pessoas excetuadas da proibição de doar ${ }^{302}$-, o $\mathrm{CC}$ de 1942 teria mantido a proibição apenas em respeito à tradição, contrariando inclusive doutrina e tribunais italianos, que já a reputavam irracional $^{303}$.

${ }^{298}$ Cf. A. DI MAJO, Codice civile con la Costituzione, i trattati U.E. e le principali norme complementari, Milano, Giuffrè, 2010, p. 350, nt. 1 ao art. 781.

${ }^{299}$ Cf. D. GRANDI, Relazione del Ministro Guardasigilli al Codice Civile cit., no 375, p. 78. A menção a exigências dignas de tutela guarda clara correspondência com o art. 1.322, segundo o qual as partes só podem celebrar contratos atípicos se atenderem a interesses merecedores de tutela segundo o ordenamento jurídico, cf. II.2.

${ }^{300}$ Cf. D. GRANDI, Relazione del Ministro Guardasigilli al Codice Civile cit., no 375, p. 78.

${ }^{301}$ Cf. B. BIONDI, Le donazioni cit., p. 9.

${ }^{302}$ Cf. I.2.1.

${ }^{303}$ Cf. R. HYLAND, Gifts cit., pp. 75-76. 
Dois outros exemplos bastante criticados de regras supostamente mantidas por força da tradição, que serão desenvolvidos ao longo do trabalho, são a exigência de forma solene ${ }^{304}$, que persiste no direito italiano, e o entendimento de que a doação não pode ter por objeto prestações de fazer. Ambas são consideradas reminiscência de uma época em que a riqueza maior era aquela imobiliária, o que talvez não faça mais sentido na sociedade contemporânea, na qual os serviços teriam assumido importância tal em relação aos bens, que teria se transformado de uma sociedade fundada no dare em uma sociedade fundada no fare $^{305}$. Esse aspecto da tradição, contudo, parece não ser suficiente, por si só, para explicar tamanha incerteza e perplexidade da doutrina em relação à configuração jurídica da doação.

\section{Possível inadequação dos conceitos de direito privado e avaliação negativa da doação}

IRTI, em seu L'ordine giuridico del mercato, define o mercado como a unidade jurídica das relações de troca, que se traduz no esquema do contrato a título oneroso. Os atos de liberalidade, e, de uma maneira mais geral, os atos gratuitos - embora sejam meios de circulação jurídica - não produzem circulação através da troca, e, logo, são externos ao conceito jurídico de mercado ${ }^{306}$.

Segundo HYLAND, como o direito privado é elaborado principalmente para atividades relacionadas ao mercado, ele teria dificuldade em lidar com uma dinâmica social essencialmente diferente. Os conceitos ligados ao mercado seriam usados para regular a doação na ausência de outros, mas seriam muitas vezes inadequados a ponto de o direito se ver obrigado a distorcê-los, criando uma confusão conceitual que levaria quase à sua descaracterização ${ }^{307}$.

Dois exemplos disso são a dificuldade em se construir a doação como um contrato $^{308}$ e a dificuldade em identificar a causa da doação, o que levará inclusive certa

\footnotetext{
${ }^{304}$ Cf. B. BIONDI, Le donazioni cit., pp. 9-10 e 15.

${ }^{305}$ Cf. G. B. FerRI, Dall'intento liberale al cosidetto impegno etico e superetico cit., pp. 45-46.

${ }^{306}$ Cf. N. IRTI, L'ordine giuridico del mercato, $4^{\mathrm{a}}$ ed., Roma, Laterza, 2001, pp. 83-84.

${ }^{307}$ Cf. R. HYLAND, Gifts cit., pp. 8-10. Pode-se ponderar, por outro lado, que "la donazione è un tipo legale spesso adoperato per realizzare operazioni meno lontane da ogni altra iniziativa economica di quel può sembrare", cf. M. BESSONE, Adempimento e rischio, Milano, Giuffrè, 1975, p. 230.

${ }^{308}$ Cf. I.7.1.
} 
corrente a propor sua substituição pela forma solene ${ }^{309}$. Há quem sugira que a doação e os atos gratuitos em geral estejam fora da dicotomia entre direito privado e o direito público, pois não serviriam nem para otimizar a busca pelo interesse próprio e nem para promover ação política voltada para objetivos sociais. GALASSO considera necessário esse reconhecimento de um "espaço social e normativo" para a gratuidade entre o Estado e o mercado, que seria um "não mercado" - nem voltado ao escopo de lucro, nem propriamente ao interesse público ${ }^{310}$.

No entendimento de HYLAND, o campo da doação, talvez mais do que qualquer outro campo regido pelo direito privado, é estruturado por normas costumeiras antes de se tornar uma instituição jurídica. E opera com relativa autonomia, pois a prática não se desenvolveu com base em mútua interação com o direito. Tem-se a impressão de que o mundo do direito e o mundo da doação estão em diferentes ambientes. Este seria uma ilha de costume social em meio a um mar de direito privado voltado para o interesse próprio ${ }^{311}$.

Esse autor questiona a excessiva preocupação do direito com a doação, pois muito do que ocorre na sociedade não deveria ser regido pelo direito. Nesse sentido, a disciplina da doação parece ser exemplo de uma "law-saturated society" (ou "società strapiena di diritti”) denunciada por RODOTÀ, em que o "imperialismo jurídico", com um caráter intenso e invasivo, passa a disciplinar o espaço do não direito, isto é, o domínio do costume, da religião e da ética. Na sociedade moderna, o direito cada vez mais seria chamado a intervir em campos da vida que deveriam ser deixados à decisão autônoma dos interessados e ao seu modo de entender a vida e as relações sociais - e a experiência

${ }^{309}$ Cf. III.4.1.

${ }^{310}$ Cf. A. GALASSO, Principio di gratuità, in Riv. crit. dir. priv 19 (2001), pp. 216-14. LIPARI é crítico à ideia de se falar em um terceiro espaço entre o Estado e o mercado, mas defende uma flexibilização tanto dos aspectos privatistas quanto dos publicistas com relação a certas figuras, cf. N. LIPARI, "Spirito di liberalità" e "spirito di soliderietà" in Riv. trim. dir. proc. civ. 51 (1997), pp. 23-24. Sobre a discussão, ainda, cf. R. HYLAND, Gifts cit., p. 115.

${ }^{311}$ Cf. R. HYLAND, Gifts cit., pp. 8-10 e 115. RODOTÀ, em sentido semelhante, mostra-se cético em relação à regulação dos atos gratuitos em geral por meio de critérios e categorias que foram criadas tendo em vista uma lógica patrimonial, e que exprimem uma postura "suspeita" com relação à atribuição de vantagens sem contrapartida, cf. S. RODOTÀ, Gratuità e solidarietà tra impianti codicistici e ordinamenti costituzionali, in A. GALASSO - S. MAZZARESE (org.), Il principio di gratuità, Milano, Giuffrè, 2008, p. 105. 
demonstraria que não há nada no mundo que o direito não queira tocar, disciplinar e $\operatorname{possuir}^{312}$.

No campo da doação, isso não é exclusivo da sociedade moderna e pode ser atribuído a uma suspeição por parte do direito que vem desde o início de sua disciplina jurídica $^{313}$. Como visto, a lex Cincia de donis et muneribus visava justamente à proibição das doações, salvo entre determinadas pessoas, e uma das razões atribuídas a isso é a desconfiança do direito com relação à sua prática ${ }^{314}$. HYLAND chega a afirmar que todo o direito ocidental é uma crítica à doação. Destaca que praticamente todos os sistemas jurídicos invalidam doações que, caso contrário, seriam aceitas na vida prática, e nenhum desses sistemas adotou uma disciplina jurídica que as favorece ${ }^{315}$.

Parece haver, com efeito, uma tendência de o direito disciplinar a doação com maior rigidez, cercando-a de cautelas ${ }^{316}$. Entre as justificativas para isso está evitar que o doador transmita gratuitamente seus bens a outrem de maneira impensada e impulsiva, com o objetivo de protegê-lo. A lei teme que o sujeito se deixe levar pela generosidade

${ }^{312}$ Cf. S RODOTÀ, La vita e le regole - Tra diritto e non diritto, reed. (2006), Milano, Feltrinelli, 2009, 9, 13 e 15-16. Agradecemos ao Prof. José Reinaldo de Lima Lopes pela referência.

${ }^{313} \mathrm{Cf}$. Ph. MALAURIE, Les successions - Les libéralités cit., pp. 146-47. É simbólico o fato de que CARVALHO DE MENDONÇA inicie sua exposição sobre a doação afirmando que "ninguém ignora a espécie de antipatia que, decorrendo da legislação romana, atingiu a todas as codificações modernas, amparada pelos mais eminentes civilistas, contra as doações, como um meio de transferir a propriedade", cf. M. I. Carvalho de Mendonça - A. Beviláqua, Contractos no Direito Civil brasileiro I, $2^{\mathrm{a}}$ ed., Rio de Janeiro, Freitas Bastos, 1938, p. 29.

${ }^{314}$ Cf. I.2.1.

${ }^{315}$ Esse autor chega ao ponto de afirmar que a doação ameaça a concepção que o direito tem de si próprio, focada no homem racional que atua no mercado maximizando utilidades. A norma jurídica, segundo o autor, tende a proibir o que não consegue integrar e como a doação apresenta uma dinâmica própria, autônoma e que não se subsume nas categorias tradicionais, ela ameaça os fundamentos do direito e a própria necessidade do direito, pois explicita que a sociedade também é estruturada por normas que dele não dependem. Para HYLAND, realizar uma doação não é, em si, um problema que exige uma solução jurídica: se o direito entende que a realização de doações é um problema que deve ser resolvido, esse problema surgiu de suas próprias premissas, e não de algo objetivamente relacionado com a prática, cf. R. HYLAND, Gifts cit., pp. 9-10, 87 e 96-98. Para BIONDI, ao contrário, a posição do direito é de indiferença nem favorável, nem contrária. A forma solene por si só não seria sinal de hostilidade, pois a escritura pública igualmente é exigida para outros atos, que são até estimulados pelo direito, como a alienação de imóveis e o matrimônio, cf. B. BIONDI, Le donazioni cit., pp. 12-15. A comparação entre a forma imposta para a doação e o matrimônio, aliás, já era mencionada na Exposição de Motivos ao CC italiano de 1865, que a justificava como uma maior garantia para o doador contra violência ou surpresa, cf. G. PISANELLI, Relazione del Ministro sul terzo libro del progetto cit., pp. 90-91.

${ }^{316}$ Para dar apenas alguns exemplos, os Códigos italiano e francês, como vimos, submetem a doação à forma solene. O CC br. a submete à forma escrita, sob pena de nulidade. Os "negócios de transmissão gratuita de bens ou remissão de dívida" (art. 158) são avaliados com maior rigor para efeitos de fraude contra credores. No direito eleitoral, a Lei 9.504/97 estabelece uma série de regras regulando e limitando a prática de doações para campanhas eleitorais, partidos e candidatos (arts. 23 e 24 ). 
"louca", frequentemente provocada pelas próprias paixões ou pela cobiça alheia ${ }^{317}$. Além disso, como a doação, aparentemente, não é baseada numa ideia racional de interesse próprio $^{318}$, o direito teme que as "boas intenções" do doador sejam um disfarce para a prática de atos contrários à ordem jurídica ${ }^{319}$, ou que acarrete diminuição de seu patrimônio a tal ponto que atinja a legítima dos herdeiros necessários ${ }^{320}$.

Com uma postura bastante crítica, HYLAND evidencia que a lógica é a seguinte: como doar algo sem contrapartida é inexplicável do ponto de vida dos protótipos de "negócio" regidos pelo direito, este entende que quem doa ou é incompetente, ou foi mal orientado. É vinculada à ideia de que favorecer outra pessoa sem contrapartida é irracional, pois fere a lógica do homo oeconomicus que atua no mercado ${ }^{321}$.

Além disso, a excessiva preocupação com a legítima dá a ideia de que os herdeiros e a família são "vítimas" quando o doador decide abdicar de seus bens, fazendo parecer que disso depende a própria sobrevivência da própria família como instituição. Em face desses aspectos, HYLAND conclui que a prática de doações é relativamente inofensiva perto do extraordinário aparato de limitações imposto pelos sistemas jurídicos. A doação não deveria demandar tanta atenção quanto a que recebe, pois não deixa de ser um ato de autonomia privada e os riscos envolvidos não são maiores do que os envolvidos, por exemplo, na celebração de um contrato que possa vir a ser prejudicial para uma das partes $^{322}$.

É interessante notar, por fim, que o teor das críticas aqui mencionadas já estava presente - embora de maneira mais branda - na Exposição de Motivos ao CC italiano de

${ }^{317}$ Cf. Ph. MALAURIE, Les successions - Les libéralités cit., pp. 146-47.

III.3.1.

${ }^{318}$ Merece destaque o "aparentemente" usado no corpo do texto. Sobre essas questões, cf.

${ }^{319}$ Cf. Ph. MALAURIE, Les successions - Les libéralités cit., pp. 146-47.

${ }^{320}$ Cf. B. BIONDI, Le donazioni cit., p. 15.

${ }^{321}$ Ainda que se esteja diante de negócios ligados ao mercado, não se pode pressupor que os sujeitos sejam sempre racionais. Nesse sentido, aponta BESSONE que a decisão de estipular um contrato, como qualquer outra decisão econômica, não é somente o resultado de um cálculo, mas tambem de juízos de valor nos quais prevalece "un apprezzamento poco razionale, se non proprio emotivo, che spesso compromete la coerenza delle valutazioni compiute e ne impedisce altre", cf. M. BESSONE, Adempimento e rischio cit., p. 5.

${ }^{322}$ Cf. R. HYLAND, Gifts cit., pp. 9-10, 87 e 96-98. 
1865. Este, como dito, manteve a forma solene para a doação, mas aboliu a exigência de aprovação pelo oficial público que constava dos códigos anteriores à unificação ${ }^{323}$.

O texto afirma essa exigência estava baseada em uma suposição errônea: a de que indivíduos sejam volúveis e inconsequentes ao se desfazer dos próprios bens em benefício de terceiros, o que é contrariado pela experiência. O mais comum, segundo o texto de PisAnelli, é que os devedores busquem meios de subtrair-se ao adimplemento de seus débitos, e não que deem aquilo que não são obrigados a dar. O texto afirma ainda que a exigência de aprovação é uma violência contra o direito do cidadão, que deve poder dispor livremente de seus bens ${ }^{324}$.

${ }^{323}$ Cf. I.4.1.

${ }^{324}$ Cf. G. PISANELLI, Relazione del Ministro sul terzo libro del progetto cit., pp. 90-91. 


\section{CAPÍTULO II - GRATUIDADE, LIBERALIDADE E DOAÇÃO - TRAÇOS DISTINTIVOS}

Este capítulo será basicamente dedicado aos critérios para se identificar os elementos característicos ou traços distintivos da doação em relação a outras figuras parecidas. Será um pressuposto para o próximo capítulo, que será dedicado a problematizar tais elementos. Este Capítulo II tratará basicamente de quatro temas. Primeiramente, falarse-á da dificuldade em se identificar elementos unificadores da doação no direito romano, dado o seu caráter prático (II.1). Em seguida, os tópicos II.2 e II.3 terão uma função instrumental. Já se partindo do pressuposto de que a doação é estruturada como contrato, a preocupação será com a delimitação do conceito de causa - cujos diversos sentidos permearão todo este trabalho - e com os critérios a serem utilizados para a delimitação dos tipos contratuais. Em terceiro lugar, será tratada a relação da doação com a gratuidade, e os possíveis critérios para se diferenciar a doação dos demais contratos gratuitos (II.4). Por fim, o capítulo se dedicará ao problema da identificação das doações indiretas (II.5), e da maneira peculiar com a qual o direito italiano as trata (como liberalidades diversas da doação - II.6). 


\section{Traços distintivos da doação no direito romano}

Modernamente, temos a ideia de que o direito é um todo coerente, um sistema integrado ou um "corpo" "325. Temos um sistema normativo fechado em que, por definição, o jurista não participa das escolhas de política legislativa e dos juízos de valor que as inspiram, limitando-se a interpretar a norma posta, que normalmente consiste em legislação ${ }^{326}$.

Segundo ZimmermanN, a partir da década de 1830, o positivismo científico tornou-se um positivismo legal, em que o direito é identificado com um corpo de disposições legais que, desde que apropriadamente postas em vigor, constituem a razão única para agir. Nesse sistema, o juiz, para decidir de modo diferente, deve necessariamente ignorar o direito anterior ou outras razões que lhe pareçam melhores ${ }^{327}$.

Não era assim no direito romano. A ciência do direito na pré-modernidade tinha um caráter prático, que consistia em uma ação ou deliberação que colocava no mundo algo novo, algo que ainda não existia ${ }^{328}$. Há importantes traços em comum compartilhados pelo direito romano (a partir do séc. II a. C.) e pela tradição jurídica ocidental, e que não estão presentes seja nos direitos germânicos anteriores ao século XI, seja em culturas contemporâneas não ocidentais ${ }^{329}$. Essa familiaridade permite e faz com que seja útil um estudo em conjunto, pois não há sentido em comparar o que é idêntico, mas também há pouco sentido em se comparar aquilo que nada tem em comum ${ }^{330}$.

Os traços em comum, segundo BERMAN, são (i) uma distinção relativamente acentuada entre instituições jurídicas e de outros tipos, como religião, costume, moral e política; estas influenciam o direito, mas ele permanece com autonomia relativa e características próprias; (ii) a existência de um corpo especial de pessoas para cuidar especificamente do direito, e que desempenham as atividades jurídicas profissionalmente; (iii) o treinamento desses juristas em escolas específicas, com uma linguagem profissional

\footnotetext{
${ }^{325}$ Cf. H. J. Berman, Law and Revolution cit., p. 9 e J. R. L. LOPES, As palavras e a lei cit., p.
}

${ }^{326}$ Cf. M. TALAMANCA, Istituzioni di diritto romano cit., p. 38.

${ }^{327}$ Cf R. Zimmermann, Roman Law, Contemporary Law, European Law cit., p. 51.

${ }^{328}$ Cf. J. R. L. LOPES, As palavras e a lei cit., p. 43.

${ }^{329}$ Cf. H. J. BERMAN, Law and Revolution cit., p. 8.

${ }^{330}$ Cf. G. Dannemann, Comparative Law cit., p. 384: "There is no point in comparing what is identical, and little point in comparing what has nothing in common". 
própria; (iv) a existência de uma ciência do direito, que é um meta-direito que analisa e avalia as instituições jurídicas, os comandos legais e as decisões. É complexa e dialética a relação com as instituições jurídicas, pois a ciência do direito, enquanto as descreve, ao mesmo tempo as conceitua, sistematiza e transforma ${ }^{331}$.

Em contrapartida, o direito romano era um sistema normativo aberto, pois os jurisconsultos eram livres para atuar no âmbito do que hoje se poderia chamar política legislativa. Os casos concretos não precisavam ser decididos da mesma maneira que os anteriores, mas podiam ser avaliados à luz de novos aspectos considerados decisivos e do reconhecimento de variáveis que autorizariam uma solução diversa. Assim, os princípios empregados na resolução dos casos concretos eram critérios que podiam sempre ser superados ou substituídos ${ }^{332}$. As doações, ao menos no período clássico, podiam ser praticadas através de diversas modalidades - in dando, in obligando e in librando ${ }^{333}$. Cabe indagar sobre a existência de elementos que estariam presentes em todas as hipóteses de doação, e, por essa razão, serviriam para unificar a categoria.

O problema, porém, é complexo ante a metodologia adotada pelos jurisconsultos romanos. A jurisprudência era essencialmente prática e considerava individualmente os casos concretos para chegar à solução jurídica do problema posto. Os problemas jurídicos eram sempre enfrentados e resolvidos através do exame de casos extraídos de obras jurídicas precedentes, ou até mesmo inventados pelo próprio jurisconsulto ${ }^{334}$.

Como consequência, as definições, as categorias gerais, as classificações e as distinções tinham como ponto de referência e limite de aplicação o caso prático em relação ao qual são mencionadas. Um método mais sistemático e classificatório, pelo menos na exposição da matéria, era reservado pelos jurisconsultos aos "manuais institucionais", ainda que os mesmos juristas não se utilizassem de tal método em outras obras ${ }^{335}$.

${ }^{331}$ Cf. H. J. BERMAN, Law and Revolution cit., p. 8.

${ }_{332}^{332}$ Cf. M. TAlamanCA, Istituzioni di diritto romano cit., p. 38.

${ }^{333}$ Cf. I.2.2.

${ }^{334}$ Cf. M. TALAMANCA, Istituzioni di diritto romano cit., pp. 35-37

${ }_{335}$ Pense-se na diferença entre as Institutas de Gaio e nos fragmentos do mesmo jurista que se encontram no Digesto, cf. M. TALAMANCA, Istituzioni di diritto romano cit., pp. 35-37. 
Por essa razão, é difícil identificar elementos gerais que deveriam estar presentes em todas as hipóteses de doação. Segundo MiCHEL, a doação no direito romano clássico jamais foi expressamente qualificada como gratuita. Somente um ato patrimonial, bilateral e não formalista poderia ser qualificado pelos jurisconsultos como gratuito (gratis, gratuito, gratuitus) ou oneroso. Como a doação clássica nunca foi um ato jurídico, mas uma causa, não era possível a sua expressa qualificação como gratuita no período clássico $^{336}$. Além disso, embora os romanos reconhecessem que a doação se caracterizava pela ausência de contrapartida ${ }^{337}$, o conceito moderno de gratuidade, segundo GIUNTI, relacionado a referenciais econômicos de aquisição e perda, não encontra correspondência exata na sistemática romana ${ }^{338}$.

Falava-se, em invés disso, na dicotomia entre donare e negotium gerere ${ }^{339}$. A distinção, todavia, não era feita com base em um critério propriamente uniforme. Por um lado, afirma-se que o negotium gerere se caracterizaria por implicar uma atividade privada em que o agente, ainda que buscasse atribuir vantagem patrimonial a outrem, procuraria também satisfazer um interesse próprio. O donare, ao contrário, implicaria uma atribuição gratuita em favor de outrem tão "absorvente e total" que tornaria juridicamente irrelevantes todos os outros interesses perseguidos. Por outro lado, diz-se que o donare se caracterizaria pela ausência de relação com causas pretéritas ou futuras. Negócios como o comodato, por exemplo, cuja causa natural seria a entrega de uma coisa, entravam na categoria de negotium gerere. Como será visto adiante ${ }^{340}$, falar na existência ou não de interesses e na existência ou não de uma causa pretérita ou futura são aspectos que, embora pareçam semelhantes, guardam diferenças entre si. Essa diferença conceitual, aliás, demonstra a incerteza que envolve o significado de donare em contraposição a negotium gerere.

${ }^{336}$ Cf. J. MiCHEL, Gratuité en droit romain, Bruxelles, Université Libre de Bruxelles - Institut de Sociologie, 1961, p. 293.

${ }^{337}$ Cf. B. BIONDI, Donazione (diritto romano) cit., p. 227.

${ }^{338}$ Cf. P. GIUNTI, Donazione (storia del diritto romano) cit., p. 164.

339 As considerações seguintes são baseadas em G. G. ARCHI, "Donare” e "negotium gerere" (1969), in Scritti di diritto romano II, in Studi di diritto privato II, Milano, Giuffrè, 1981, especialmente pp. 953, 964 e 968-69, G. G. ARCHI, Donazione (diritto romano) cit., p. 931 e P. GIUNTI, Donazione (storia del diritto romano) cit., p. 164. ARCHI contraria a posição de PRINGSHEIM de que seriam interpoladas todas as referências a donare e negotium gerere existentes nas fontes.

${ }^{340}$ Cf. III.4.3. e III.5.1. 
Outro elemento necessário para a caracterização da doação teria sido o animus donandi, ou seja, o "intento de praticar um ato de liberalidade",341, que deveria ser aceito pelo donatário, não se exaurindo no foro interno do doador ${ }^{342}$. Seria a vontade voltada à causa donationis, e não propriamente à prática do ato - como a mancipatio - através do qual a causa se manifesta ${ }^{343}$. O animus donandi não se confundiria com a vontade de praticar o ato de atribuição, mas seria um elemento qualificador da vontade negocial cuja presença seria necessária para a caracterização de um ato praticado donationis causa ${ }^{344}$.

Não há concordância entre os romanistas, entretanto, sobre os períodos do direito romano em que tal elemento era necessário. PRINGSHEIM, em artigo considerado clássico, sustentou que a expressão seria sempre interpolada nos textos clássicos por obra dos juristas bizantinos ${ }^{345}$. Os jurisconsultos clássicos, para identificar determinada situação como doação, limitar-se-iam ao exame da situação objetiva da atribuição gratuita ${ }^{346}$. Por outro lado, a doutrina mais recente parece ter consolidado entendimento de que não há razões suficientes para se suspeitar dos fragmentos em que se faz menção ao animus donandi $i^{347}$.

${ }^{341}$ Cf. M. MARRONE, Istituzioni di diritto romano cit., p. 557.

${ }^{342} \mathrm{Cf}$. M. TALAMANCA, Istituzioni di diritto romano cit., p. 773.

${ }^{343}$ Cf. B. BIONDI, Donazione (diritto romano) cit., p. 227.

${ }^{344}$ Cf. S. BroIse, Appunti sull' "animus donandi”, in BIDR 67 (1964), pp. 229-31.

${ }^{345}$ Cf. F. PringSheIM, Animus donandi, in SZ 42 (1921), pp. 273 ss., artigo referido por G. G. Archi, La donazione cit., p. 50-51 e S. BROISE, Appunti sull' “animus donandi" "cit., p. 227, nt. 3. Também do autor é a obra posterior S. BROISE, Animus donandi - Concetto romano e suoi riflessi sulla dogmatica odierna I e II, Pisa, Pacini, 1975.

${ }^{346}$ Cf. F. PringSheim, Animus donandi cit., p. 236: "Das Ergebnis läßt sich dahin zusammenfassen: Sowohl die Absicht der Liberalität wie der animus donandi sind byzantinische Erfordernisse der Schenkung" [= "Os resultados podem ser resumidos como se segue: tanto a intenção liberal quanto o animus donandi são requisitos bizantinos da doação"]. É interessante notar, como faz S. BROISE, Appunti sull' "animus donandi" cit., p. 227, nt. 3, que a posição de PRINGSHEIM foi atenuada em um artigo publicado doze anos depois. $\mathrm{O}$ autor, com efeito, afrmou que os juristas clássicos levavam em consideração $\mathrm{o}$ elemento subjetivo apenas quando a vontade era expressa, deduzida da declaração ou dos fatos, cf. F. PringSheim, Animus in Roman Law, in L. Q. Rev. 49 (1933), especialmente p. 48. Ademais, PringhSEIM, em um terceiro artigo chamado Liberalitas, in Studi in memoria di Emilio Albertario I, Milano, Giuffrè, 1953 , p. 678 , nt. 1, termina por considerar genuínos alguns textos antes considerados interpolados, concordando com algumas colocações de ARCHI, apesar de (sempre segundo BROISE para os textos em língua alemã) aparentemente ter endurecido novamente a sua posição em crítica à obra de G. G. ARCHI, $L a$ donazione cit., publicada em SZ 78 (1961), pp. 474-84 (especialmente p. 478).

${ }^{347}$ Nesse sentido, e por todos, cf. M. TALAMANCA, Istituzioni di diritto romano cit., p. 773. 
Para BIONDI, por exemplo, os jurisconsultos clássicos não prescindiram dele, e a expressão é, no mais das vezes, genuína nas fontes ${ }^{348}$. ARCHI defende uma posição intermediária. Embora o elemento subjetivo fosse indispensável para a caracterização da causa donationis do período clássico, há fragmentos claramente interpolados, nos quais a expressão animus donandi é mencionada com relação a institutos jurídicos que claramente não a toleravam ${ }^{349}$.

A tese de BroISE, por fim, sustenta que o animus donandi só seria relevante para a concepção clássica da doação enquanto causa, em que servia para diferenciar os negócios abstratos - como a mancipatio e a stipulatio - praticados em razão da causa donationis daqueles praticados em razão de alguma outra causa ${ }^{350}$.

Com a transformação da doação em um negócio jurídico típico no direito pósclássico, o animus donandi teria perdido toda a sua importância, pois o animus de praticar a gratuidade se confundiria com a vontade direcionada à prática do próprio ato jurídico, que agora seria o negócio específico de doação. Assim, a BROISE não parece ser possível que os juristas justinianeus tenham alterado sistematicamente os textos clássicos para incluir referência ao animus donandi, pois tal requisito teria perdido toda a importância com a transformação da doação em tipo de negócio ${ }^{351}$. Esse posicionamento, transportado para o direito moderno, encontra ressonância na posição de BIONDI de que o animus donandi seria desnecessário para caracterizar o contrato típico de doação, mas serviria, da

${ }^{348}$ Cf. B. BIONDI, Donazione (diritto romano) cit., p. 227. BIONDI acabou sendo criticado por supostamente não ter efetuado um exame orgânico e completo dos textos em que a expressão aparece e, com relação aos textos que examina, por acabar dando excessiva relevância para o animus donandi, cf. S. BROISE, Appunti sull'“animus donandi" cit., p. 227.

${ }^{349}$ Cf. G. G ARCHI, La donazione cit., pp. 53-54; G. G. ARCHI, Animus donandi (1951), in Scritti di diritto romano II cit., p. 1075. Uma crítica feita ao posicionamento de ARCHI é no sentido de que, embora conclua que o animus donandi é requisito clássico, sua conclusão contradiz a exegese que ele próprio faz dos fragmentos. ARCHI acaba, na maior parte das vezes, por concordar com PRINGSHEIM, considerando interpolados praticamente todos os fragmentos em que a expressão aparece, com exceção de três, cf. S. BROISE, Appunti sull'“animus donandi” cit., pp. 246 e 228.

${ }^{350}$ Cf. S. Brolse, Appunti sull'“animus donandi”"cit., pp. 229-31. O autor, aliás, conclui que “i classici sono riusciti a creare un mirabile equilibrio fra l'elemento soggettivo e quello oggettivo della donazione. Nel quadro di tale equilibrio, l'animus donandi non è qualcosa di concettualmente statico, privo do applicazioni pratiche, ma il fattore dinamico, al quale la giurisprudenza ricorre, una volta accertata la presenza dell'arrichimento (è quindi indispensabile anche l'elemento oggettivo), per stabilire se nella fattispecie considerata sia da vedere una donazione", cf. S. BROISE, Animus donandi - Concetto romano e suoi riflessi sulla dogmatica odierna II - Parte speciale; Indici, Pisa, Pacini, 1975, p. 237. Com relação ao enriquecimento como traço característico da doação romana, criticamente cf. III.1.1.

${ }^{351}$ Cf. S. BROISE, Appunti sull'“animus donandi”'cit., pp. 229-31. 
mesma forma que no direito romano clássico, para identificar as liberalidades diversas da doação $^{352}$.

${ }^{352}$ Cf. B. BIONDI, Le donazioni cit., pp. 94-95 e 101 e II.6.2. 


\section{Sentidos de "causa" relevantes para o estudo da doação}

\section{Sentidos de causa e a causa da obrigação (ou da prestação)}

O conceito de causa é um dos mais ambíguos e polissêmicos do direito civil ${ }^{353}$. Este trabalho não tem a pretensão de esgotar o assunto, que, por si só, justificaria uma pesquisa própria. Todavia, é necessário, com um objetivo instrumental - e com ciência de todo o risco inerente às simplificações apressadas - fixar alguns dos conceitos de causa que são relevantes para o estudo da doação.

No caso desta, talvez mais do que em outros institutos de direito privado, a ideia de causa parece estar sempre subjacente, envolvendo muitos de seus aspectos. Nesse ponto, é necessário fazer uma diferença fundamental. Algumas concepções de causa a veem como causa da obrigação ou do deslocamento patrimonial, individualmente considerados - a que chamaremos causa da "prestação" em sentido amplo. Outras concepções a entendem como causa do negócio jurídico como um todo ${ }^{354}$.

O Code civil trata expressamente da causa no primeiro sentido. Em seu art. 1.108, estabelece que são quatro as condições de validade das convenções, e uma delas é a causa lícita da obrigação ${ }^{355}$. O CC italiano de 1942, ao tratar dos requisitos do contrato, menciona simplesmente "a causa", o que permite entendê-la no segundo sentido (art. $1.325)^{356}$.

${ }^{353}$ Cf. A. JUNQUEIRA DE AZEVEDO, Negócio jurídico e declaração negocial - Noções gerais e formação da declaração negocial, Tese (Titularidade), São Paulo, Faculdade de Direito da Universidade de São Paulo, 1986, pp. 121-29. JUNQUEIRA DE AZEVEDO expõe bem essa multiplicidade de sentidos, ao identificar as seguintes acepções: causa-fato jurídico (causa efficiens), causa-motivo (causa impulsiva, se subjetiva, ou causa-justa causa, se objetiva), causa da juridicidade (civilis ou naturalis), causa da atribuição patrimonial (ou atribuição de direitos) e causa do negócio (causa finalis com três concepções).

${ }^{354}$ Cf. G. B. FERRI, Dall'intento liberale al cosidetto impegno etico e superetico cit., pp. 72-73 e 77 e M. GIORGIANNI, Causa (diritto privato), in ED 6 (1960), p. 547. GHESTIN, ao mencionar a dicotomia feita pela doutrina francesa entre causa da obrigação e causa do contrato, a trata de maneira diferente. Segundo o autor, a causa da obrigação é que é objetiva, abstrata e a mesma para todo tipo de contrato, enquanto é a causa do contrato que tem a função de controlar a licitude e a moralidade, pois se relaciona aos motivos ilícitos ou imorais, cf. J. GHESTIN, Cause de l'engagement et validité du contrat, Paris, LGDJ, 2006, p. 6.

${ }^{355}$ Art. 1.108. Quatre conditions sont essentielles pour la validité d'une convention : Le consentement de la partie qui s'oblige ; Sa capacité de contracter ; Un objet certain qui forme la matière de l'engagement; Une cause licite dans l'obligation.

${ }^{356}$ Art. 1.325. Indicazione dei requisiti - I requisiti del contratto sono: 1) l'accordo delle parti; 2) la causa; 3) l'oggetto; 4) la forma, quando risulta che è prescritta dalla legge sotto pena di nullità. 
Segundo PENTEAdO, embora o CC brasileiro não trate expressamente da causa como requisito do ato jurídico $^{357}$, pode-se afirmar com relativa segurança que existe uma teoria brasileira da causa. A causa seria geralmente analisada sob a perspectiva da conexão entre "as fases obrigacionais e reais" dos negócios jurídicos e raramente seria vista como causa do negócio - normalmente é concebida como causa da obrigação ${ }^{358}$.

Simplificadamente, pode-se dizer que a causa da prestação pode ser vista como causa de juridicidade, causa de atribuição patrimonial e causa impulsiva ou final ${ }^{359}$. Como causa de juridicidade, está relacionada à rejeição da obrigatoriedade da nuda promessa e à ideia de que a vontade negocial só é juridicamente relevante se for justificada - rejeitando-se a generalização do princípio de que o mero consentimento obriga ${ }^{360}$.

No direito romano, o mero acordo - nudum pactum - não era contrato, e não fazia surgir obrigações entre as partes. Os contratos eram típicos (tipicidade fechada) e geravam obrigações na medida em que eram justificados por uma causa. Esta podia consistir em formalidades (contratos formais ou verbais), forma escrita (contratos literais) ou entrega de uma coisa (contratos reais). O mero consentimento só justificava o surgimento de obrigação em casos específicos, que foram se generalizando com passar do tempo, como nos contratos de compra e venda, locação, mandato e sociedade (contratos consensuais) $^{361}$.

Segundo JUNQUEIRA DE AZEVEDO, a causa de juridicidade pode ser classificada em natural ou civil. A causa natural faz surgir a obrigação por conta da natureza das coisas. É o caso da entrega do bem nos contratos reais, que gera a obrigação de restituir. A causa civil gera obrigação por conta de uma "convenção social", e substitui a causa natural

${ }^{357}$ Cf. P. B. CAMPos FiLHo, O problema da causa no Código Civil brasileiro, São Paulo, Max Limonad, s.d., pp. 26-27.

${ }^{358}$ Cf. L. C. PenTEAdo, Doação com encargo e causa contratual cit., pp. 118-19 e 124. Para as principais referências bibliográficas sobre causa no direito brasileiro, cf. p. 122. Segundo JUNQUEIRA DE AZEVEDO, "no direito brasileiro, procura-se ignorar a noção de causa, que, entretanto, acaba surgindo, quando se distinguem os negócios causas dos abstratos, ou quando o próprio legislador se refere à 'justa causa"”, cf. A. JUNQUEIRA DE AZEVEDO, Negócio jurídico cit., p. 154.

${ }^{359}$ A causa pode ter a função de dar juridicidade, determinar ineficácia superveniente ou ser requisito de outro ato, por exemplo, cf. L. C. PENTEADO, Doação com encargo e causa contratual cit., pp. $412-13$.

${ }^{360}$ Cf. C. M. BIANCA, Diritto civile III, pp. 458-59.

${ }^{361}$ Cf. M. MARRONE, Istituzioni di diritto romano cit., pp. 433-37 e 485. 
quando esta não existe ${ }^{362}$. A causa de juridicidade serve para colocar limites à liberdade contratual. Com a generalização da ideia de que o simples consentimento dos contratantes gera obrigações e de que as partes são árbitras dos próprios interesses, fala-se em uma diminuição de importância dessa concepção ${ }^{363}$.

Todavia, como será visto adiante, uma importante corrente teórica desenvolvida por GORLA e à qual se filia, entre nós, PENTEADO, dá importância à exigência da causa de juridicidade como limitação à liberdade de doar, por se tratar de um ato em que é ausente a contraprestação ${ }^{364}$. PENTEADO, aliás, afirma que a causa no campo dos contratos é o fundamento de um dever, o elemento concreto que justifica uma obrigação $\operatorname{assumida}^{365}$.

Entendida como causa de atribuição patrimonial ${ }^{366}$, a causa está relacionada à distinção entre negócios causais e abstratos. O deslocamento patrimonial provocado por um negócio abstrato, como a mancipatio romana, pode ser justificado por uma doação (causa donandi) ou por uma causa credendi ou solvendi ${ }^{367}$. Essa noção é especialmente relevante nos sistemas que adotam a separação entre os planos do direito das obrigações e o plano dos direitos reais ${ }^{368}$, como o alemão, no qual o acordo de transmissão de propriedade - como a mancipatio romana - é eficaz não obstante eventual defeito no negócio que lhe deu origem ${ }^{369}$.

${ }^{362}$ Cf. A. JUNQUEIRA DE AZEVEDO, Negócio jurídico e declaração negocial cit., pp. 121-24.

${ }^{363}$ C. M. BIANCA, Diritto civile III, pp. 458-59 e A. JUNQUEIRA DE AZEVEDO, Negócio jurídico e declaração negocial cit., pp. 124-26.

${ }^{364}$ Cf. III.4.1.

${ }^{365}$ Cf. L. C. PENTEADO, Doação com encargo e causa contratual cit., pp. 412-13.

${ }^{366}$ Outras causas de "atribuição de direitos" - não mais "de atribuição patrimonial" podem ser identificadas em negócios não patrimoniais, cf. A. JUNQUEIRA DE AZEVEDO, Negócio jurídico e declaração negocial cit., pp. 124-25.

${ }^{367}$ Segundo JUNQUEIRA DA AZEVEDO, as principais espécies com relação aos negócios patrimoniais são a credendi, a solvendi e a donandi. No caso da causa credendi, o crédito de uma parte justifica o crédito da outra, como ocorre nos contratos sinalagmáticos. Na compra e venda, por exemplo, a obrigação do comprador justifica a obrigação do vendedor e vice-versa. No caso da causa solvendi, um crédito já existente justifica o cumprimento da obrigação pelo devedor. Enquanto as causas credendi e solvendi se referem a atos sinalagmáticos, e a causa donandi diz respeito a atos não sinalagmáticos. Verificase, por exemplo, nos casos em que "B tornou-se credor porque A quis doar", cf. A. JUNQUEIRA DE AZEVEDO, Negócio jurídico e declaração negocial cit., pp. 124-26.

${ }^{368}$ Falar simplesmente em plano dos direitos reais pode ter um significado restrito, insuficiente para abarcar todas as hipóteses; mais adequado, talvez, seja falar em plano de atribuição de direitos.

${ }^{369}$ Cf. L. C. PENTEADO, Doação com encargo e causa contratual cit., pp. 116-17. 
No Brasil, que adotou o sistema da separação relativa entre os planos, o registro de propriedade gera apenas uma presunção iuris tantum do domínio, ao contrário do sistema alemão, no qual essa presunção é iuris et de iure ${ }^{370}$. O resultado disso é que não há negócios absolutamente abstratos no direito brasileiro, mas apenas os relativamente abstratos, pois a falta de causa terá relevância inter partes ${ }^{371}$.

A ideia de causa impulsiva, por sua vez, está relacionada aos motivos que levam o agente a praticar o ato. Dependendo da concepção adotada, trata-se tanto das razões psicológicas quanto das razões objetivas que precedem e determinam a declaração negocial $^{372}$. Essas razões estão ligadas ao fim perseguido pelo agente, o que permite falar em causa final ${ }^{373}$. A concepção teve seu maior desenvolvimento na França, e conheceu duas vertentes - a teoria subjetiva e a teoria objetiva clássica ${ }^{374}$.

JUNQUEIRA DE AZEVEDO prefere denominá-las, respectivamente, teoria subjetiva e teoria subjetivo-objetiva ${ }^{375}$, para diferenciar esta última da causa-função. Para a primeira teoria, a causa é, entre os vários motivos que inspiram o agente, aquele próximo ou determinante. Para a segunda teoria, a causa é o fim objetivamente pretendido com o negócio ou o but em vista do qual a pessoa se obriga, que varia de acordo com a natureza do negócio ${ }^{376}$

À medida em que se adota uma perspectiva mais objetiva e se desvincula dos motivos, a causa passa a ser constante em cada tipo de negócio e a identificar-se com a contraprestação ou com algo que consista no fundamento da atribuição patrimonial ${ }^{377}$. Assim, nos contratos bilaterais sinalagmáticos, a causa de uma prestação é a contraprestação; nos contratos reais, a causa é a entrega da coisa ${ }^{378}$. O problema maior

${ }^{370}$ Cf. C. V. Couto e Silva, A obrigação como um processo cit., pp. 52-55 e M. H. DinIZ, Sistemas de registros de imóveis, $11^{\mathrm{a}}$ ed., São Paulo, Saraiva, 2014, pp. 43-44.

${ }^{371}$ Cf. A. JunQueIRA DE AZEVEDO, Negócio jurídico cit., pp. 140-41 e 143.

${ }^{372}$ Cf. A. JUNQUEIRA DE AZEVEDO, Negócio jurídico cit., p. 137 e A. JUNQUEIRA DE AZEVEDO, Negócio jurídico e declaração negocial cit., pp. 210-14.

${ }^{373}$ Sobre a difícil distinção entre a causa impulsiva e a causa final, cf. F. CALASSO, Il negozio giuridico - Lezioni di storia del diritto italiano, Milano, Giuffrè, 1967, pp. 293-95.

${ }^{374}$ Cf. C. M. BIANCA, Diritto civile III cit., pp. 449-50.

${ }^{375}$ Cf. A. JUNQUEIRA DE AZEVEDO, Negócio jurídico e declaração negocial cit., p. 127.

${ }^{376}$ Cf. H. CAPITANT, De la cause des obligations cit., pp. 81-82.

${ }^{377}$ Cf. C. M. BIANCA, Diritto civile III cit., pp. 449-50.

${ }^{378}$ Cf. A. JUNQUEIRA DE AZEVEDO, Negócio jurídico e declaração negocial cit., pp. 126-27. 
surge justamente em relação à doação, em que a aparente ausência de causa faz com que o papel da causa seja identificado com o animus donandi ou até com a forma solene ${ }^{379}$.

\section{Causa do negócio - causa abstrata e causa concreta}

Outra visão acerca da causa, que se desenvolveu na Itália, a entende como causa do negócio como um todo ${ }^{380}$. Inicialmente, naquele país, a concepção de causa era semelhante à que se desenvolveu no direito francês. O art. 1.104 do CC de 1865, aliás, era uma tradução do art. 1.108 do Code civil, e estabelecia que um dos requisitos de validade dos contratos era uma causa lícita para se obrigar ${ }^{381}$.

Parte da doutrina, contudo, foi se afastando dessa concepção e transportou o problema da causa da prestação considerada individualmente para a causa como função do negócio $^{382}$. Essa ideia encontra apoio na noção de liberdade contratual adotada pelo art. 1.322, 2 do CC de 1942, segundo o qual as partes são livres para celebrar contratos atípicos desde que sejam voltados a realizar interesses merecedores de tutela segundo o ordenamento jurídico ${ }^{383}$.

A causa do negócio passa a ser construída como a sua função econômicosocial $^{384}$, que corresponde aos referidos interesses merecedores de tutela, e é a mesma para cada tipo negocial, como fator de coesão entre os demais elementos mencionados pelo legislador ${ }^{385}$. O principal jurista que desenvolveu essa concepção foi BETTI, para quem "la causa del negozio è propriamente la funzione economico-sociale che caratterizza il tipo di

${ }^{379}$ Cf. III.4.1.

${ }^{380}$ Nesse sentido, a causa tem a função de justificar a operação jurídico-econômica, cf. P. MOROzzo DELla RoCCA, Gratuità, liberalità e solidarietà cit., p. 38.

381 Art. 1.104. I requisiti essenziali per la validità di un contratto sono: La capacità di contrattare; Il consenso valido dei contraenti; Un oggetto determinato che possa essere materia di convenzione; Una causa lecita per obbligarsi.

${ }^{382}$ Cf. G. B. FERRI, Dall'intento liberale al cosidetto impegno etico e superetico cit., pp. 72-73 e 77 .

${ }^{383}$ Art. 1.322 , 2. Le parti possono anche concludere contratti che non appartengono ai tipi aventi una disciplina particolare, purché siano diretti a realizzare interessi meritevoli di tutela secondo l'ordinamento giuridico.

Salta aos olhos, aliás, a semelhança entre esse dispositivo e o art. 421 do CC br., segundo o qual "a liberdade de contratar será exercida em razão e nos limites da função social do contrato", cf. L. C. PENTEADO, Doação com encargo e causa contratual cit., p. 113.

${ }^{384}$ Cf. A. JUNQUEIRA DE AZEVEDO, Negócio jurídico cit., p. 150.

364 e 372.

${ }^{385}$ Cf. G. B. FerRI, Causa e tipo nella teoria del negozio giuridico, Milano, Giuffrè, 1966, p. 
esso negozio quale fatto di autonomia privata (tipica, in questo senso) e ne determina il contenuto minimo necessario" 386 .

Concebida dessa forma, a causa acarreta consequências relevantes: (i) tem um viés autoritário, pois leva a um controle pelo Estado da relevância dos interesses que condiciona o reconhecimento jurídico dos contratos atípicos a um critério de "utilidade social" ${ }^{387}$; (ii) há uma nítida separação entre causa e motivo, pois os motivos e os fins perseguidos individualmente pelas partes ficam fora do âmbito da causa ${ }^{388}$; e (iii) aproxima-se demais da ideia de tipo negocial, fazendo com que haja uma verdadeira confusão entre os dois conceitos ${ }^{389}$.

Haveria certa perda de relevância e autonomia da noção de causa, que, vista como uma síntese dos efeitos jurídicos essenciais do negócio, acabaria um "tanto estérill 390 . Diante de um contrato típico concretamente celebrado, a causa perderia a sua função de controle quanto à licitude da operação negocial ${ }^{391}$, pois o esquema abstrato ao qual corresponde já seria reconhecido como cumpridor de uma função socialmente útil ${ }^{392}$.

${ }^{386}$ Cf. E. BETTI, Teoria generale del negozio giuridico cit., p. 181.

${ }^{387}$ Cf. G. B. FERRI, Causa e tipo nella teoria del negozio giuridico cit., p. 361. No limite, seria quase como se as partes contratantes fossem funcionários públicos encarregados de perseguir o bem comum (conforme entendido pelo Estado), cf. P. MOROZZO DELlA ROCCA, Gratuità, liberalità e solidarietà cit., p. 110 .

${ }^{388}$ Segundo BESSONE, o problema dessa concepção é que não deixa espaço para motivos juridicamente relevantes (que assim o são considerados pelo próprio CC de 1942, como nos arts. 787 e 788 ). Trata-se de interesses que nem integram a causa enquanto função econômico-social abstrata e nem são propriamente motivos irrelevantes, de acordo com a "classica formula", cf. M. BESSONE, Adempimento e rischio cit., pp. 214-17. Nas suas palavras: "se si esaurisce la causa del contratto negli interessi che ne costituiscono la funzione economico-sociale, e al contempo si qualificano come motivi tutti gli interessi diversi che non siano contemplati da una clausola, manca qualsiasi possibilità di trovare spazio per una figura a mezzo tra l'una e l'altra" (p. 218).

${ }^{389}$ Cf. G. DE NovA, Il tipo contrattuale cit., pp. 60-62. Segundo o autor, "è certo esatto vedere in tale richiamo un'epifania della confusione - ormai più volte denunciata - fra causa e tipo"; em seguida menciona uma "confusione tra i due profili del contratto" (p. 60). No mesmo sentido, para outro autor a concepção de causa abstrata implicava uma "coincidenza tra causa e tipo", cf. P. MorOzZO DELLA RocCA, Gratuità, liberalità e solidarietà cit., p. 21.

${ }^{390}$ Cf. G. DE NOVA, Il tipo contrattuale cit., pp. 60-62. Segundo JUNQUEIRA DE AZEVEDO, a causa como função abstrata "pouco influi na validade e eficácia de cada negócio concreto", servindo para a "boa compreensão de cada instituto e de cada tipo de negócio", cf. A. JUNQUEIRA DE AZEVEDO, Negócio jurídico e declaração negocial cit., p. 128.

${ }^{391}$ Sobre a função da causa no controle da licitude da operação negocial, cf. C. M. BIANCA, Diritto civile III, pp. 458-59. Cf. M. GIORGIANNI, Causa (diritto privato) cit., p. 573: à causa, da maneira como foi absorvida pela noção de tipo, acabou sendo atribuída a função de controle das razões e limites da autonomia privada na escolha dos tipos contratuais; essa função da causa é estranha à tradicional, que é a de justificar perante o ordenamento a movimentação dos bens de um indivíduo a outro. Bastante crítico da ideia de causa como função econômico-social (abstrata), BESSONE destaca que é impossível reduzir a razão 
A doutrina posterior procurou resolver esses aspectos problemáticos. Foram sendo desenvolvidas novas concepções de autonomia privada e liberdade contratual que garantem um maior espaço para o exercício da liberdade individual. De um controle positivo por parte do Estado acerca do "merecimento" de tutela dos interesses, passou-se a propor ou um controle negativo, isto é, só não são merecedores de tutela aqueles interesses contrários ao ordenamento jurídico (perspectiva mais ampla), ou uma exigência positiva de compatibilidade dos interesses das partes com valores constitucionais, como a dignidade humana e a solidariedade social (perspectiva mais restrita) ${ }^{393}$.

Desenvolveu-se também a ideia de causa concreta, entendida como função econômico-individual - em oposição à função econômico-social (causa abstrata). Nessa nova concepção, a causa serve para avaliar, em concreto, o modo como o esquema abstrato é utilizado, isto é, se o interesse concretamente perseguido corresponde ao interesse tipificado como "merecedor de tutela" e, de um modo geral aos princípios do ordenamento jurídico $^{394}$.

A causa concebida dessa maneira volta a ganhar autonomia em relação ao tipo e a abarcar o fim ou motivo determinante que inspira os declarantes na prática dos negócios ${ }^{395}$. É uma especificação da função econômico-social para cada negócio singularmente celebrado, que exprime uma síntese entre a causa abstrata - efeitos jurídicos

justificadora do contrato "alla serie di elementi che ne costituiscono la funzione legale", como se pudesse "esaurire la cernita degli interessi delle parti giuridicamente apprezzabili", cf. M. BESSONE, Adempimento e rischio cit., pp. 262 e 268 , principalmente.

${ }^{392}$ Cf. G. B. FerRI, Causa e tipo nella teoria del negozio giuridico cit., pp. $358-59$ e 372. Segundo MoROzZo DELla ROCCA, uma vez identificada a causa com o tipo, não poderá faltar ou ser ilícita: a única conclusão possível é a não configuração do tipo, cf. P. MOROZzo DELLA ROCCA, Gratuità, liberalità e solidarietà cit., p. 51.

${ }_{393}$ Cf. C. M. BIANCA, Diritto civile III cit., pp. 458-60.

${ }^{394}$ Cf. G. B. FERRI, Causa e tipo nella teoria del negozio giuridico cit., pp. 358-59 e 372.

${ }^{395}$ Não se trata de voltar a proceder a um controle acerca do motivo-interesse psicológico (lícito ou ilícito) que levou as partes a praticar os atos, mas o interesse "quale funzione oggettivamente svolta dal contratto", cf. P. MOROzzo DELla RoCCA, Gratuità, liberalità e solidarietà cit., p. 41. Segundo ALPA, "il giudice non può prescindere da quelle circostanze che, pur non essendo espressamente previste nel (o dedotto in) contratto, hanno tuttavia concorso a formare la comune volontà delle parti o hanno spinto I singoli soggetti alla contrattazione". Segundo o autor, deve-se chegar a um meio-termo entre o dogma da completa irrelevância dos motivos e uma acentuada objetivação dos caracteres da causa, cf. G. ALPA, Atto di liberalità e motivi dell'attribuzione, in Riv. trim. dir. proc. civ 26 (1972), p. 364. 
essenciais do tipo negocial - e o motivo determinante ou fim que leva as partes à prática do ato $^{396}$.

À causa entendida como função costuma-se atribuir um papel relevante na identificação dos tipos contratuais. Isso era evidente com a causa entendida como causa abstrata, mas mesmo à causa concreta vem atribuída relevância na identificação do tipo. Segundo BIANCA, como os tipos contratuais são modelos de operações econômicas recorrentes na vida prática, a causa concreta é a base da qualificação de um contrato celebrado como um dos contratos típicos quando há uma compatibilidade entre interesses e

${ }^{396}$ Cf. C. M. BIANCA, Diritto civile III cit., pp. $452-53$ e 461. Em um modo esquemático: causa concreta $=$ causa abstrata + motivo determinante. Em relação a este último, MoROzZO DELLA RoCCA aponta a necessidade de se diferenciar entre o motivo ("comum" ou "interesse-motivo) e o "intento prático" (ou "interesse causal”, que integra a causa concreta). Enquanto este seria um escopo imediatamente safisfeito pelo negócio, aquele demandaria uma determinação ulterior em relação à operação jurídico-econômica, cf. $P$. MorOzzo Della RocCA, Gratuità, liberalità e solidarietà cit., pp. 47-48. Na terminologia de DEL NERO, trata-se de identificar mais uma etapa na cadeia dos diversos "fins" visados pelas partes para concluir o negócio, cf. J. A. S. DEL NERO, Conversão substancial do negócio jurídico cit., pp. 58-65 (cf. nt. 691, infra). O CC br. refere-se ao "motivo determinante" no art. 166, III, alçando-o à categoria de requisito de validade do negócio jurídico, ao afirmar ser nulo o negócio jurídico quando "o motivo determinante, comum a ambas as partes, for ilícito". Da mesma forma, o art. 137 estabelece que o "encargo ilícito ou impossível” dá ensejo à invalidade do negócio jurídico quando "se constituir o motivo determinante da liberalidade". O art. 140, por sua vez, ao tratar do erro enquanto defeito do negócio jurídico, estabelece que "o falso motivo só vicia a declaração de vontade quando expresso como razão determinante". Trata-se, novamente, de requisito de validade, uma vez que o vício resultante de erro pode conduzir à anulação do negócio jurídico (art. 171, II). A referência ao "falso motivo" veio a substituir a que era feita à "falsa causa", no dispositivo equivalente do CC de 1916 (Art. 90. Só vicia o ato a falsa causa, quando expressa como razão determinante ou sob forma de condição) o que foi tudo como uma "impropriedade" por MoreIRA ALVES, cf. J. C. MorEIRA ALVES, O negócio jurídico no projeto de Código Civil brasileiro - Análise comparativa com o Código Civil português de 1967, in A parte geral do projeto de Código Civil brasileiro - Subsídios históricos para o novo Código Civil brasileiro, $2^{a}$ ed., São Paulo, Saraiva, 2003, p. 117. De acordo com JUNQUEIRA DE AZEVEDO, a regra é a da irrelevância dos motivos psicológicos para a validade e eficácia da declaração. Os motivos, assim, não integram o objeto do negócio nem explícita nem implicitamente, pois "são do agente e nele estão", cf. A. JUNQUEIRA DE AZEVEDO, Negócio jurídico cit., p. 137 e A. JUNQUEIRA DE AZEVEDO, Negócio jurídico e declaração negocial cit., pp. 210-15. No caso do art. 140, para que "façam parte do objeto (e, portanto, do negócio) é preciso que" os motivos "sejam referidos no objeto como motivos determinantes (e, então, serão conteúdo expresso)". A motivação é a expressão dos motivos, ou a fundamentação, que será relevante quando for expressa como razão determinante, isto é, o motivo declarado passa a integrar o objeto da declaração. Essa motivação, algumas vezes, é exigida expressamente pela própria lei, mas, em regra, sua inclusão fica a critério das partes. No caso da motivação determinada em lei, o autor afirma que tem a função de obrigar "o declarante a se conscientizar da adequação de sua declaração às exigências do preceito, legal ou contratual" e facilitar, "para os declaratários, o controle dessa mesma adequação". O art. 166, III, por outro lado, não diz respeito propriamente à motivação expressa na declaração, mas aos "fins da declaração". Embora a linguagem tenha um tom subjetivista, "a questão, no fundo, é objetiva", pois não se trata de investigar os "motivos do agente", em uma análise psicológica, mas de uma análise objetiva, que "pouco tem a ver com o que as partes pensaram", mas sim "com o resultado que surgirá dos efeitos da declaração". 
finalidades concretamente perseguidos pelas partes e os interesses negociais típicos previstos para cada modelo contratual ${ }^{397}$.

${ }^{397}$ Cf. C. M. BIANCA, Diritto civile III cit., pp. 472-77. Para DE NovA, porém, a ideia de que a identificação do tipo se faz com base na causa é artificial e parece não respeitar o direito positivo, pois muitas vezes os tipos legais são individuados por elementos que não conseguem ser reconduzidos à causa sem se forçar a situação em um modo evidente e exagerado. Além disso, cria-se um círculo vicioso, pois ou a função é elaborada com base nas características do tipo legal - e, assim, não é apta a determinar quais são as características - ou é determinada antes e independentemente do tipo legal, de maneira que não se consegue ver nela a base do critério de individuação trazido pela lei, cf. G. DE NovA, Il tipo contrattuale cit., p. 64. 


\section{Notas sobre a identificação do tipo contratual no direito moderno}

Segundo CATAUdella, a disciplina de cada contrato comumente se inicia com um dispositivo legal que o delineia. O legislador normalmente faz referência às "prestações" em sentido amplo, compreendidas não só como aquelas decorrentes de uma obrigação, mas como os resultados atingidos pelos contratos com efeitos reais. Com esse delineamento ocorre a individuação do conteúdo essencial do contrato, permitindo a especificação das fattispecie concretas, às quais serão aplicadas as regras previstas para o tipo $^{398}$.

Conforme aponta DE NovA, deve-se admitir que o legislador é livre para traçar os confins do tipo segundo seus próprios critérios e utiliza critérios variados e heterogêneos para diferenciar os tipos contratuais. Os elementos caracterizantes do tipo, na realidade, são os traços distintivos entre os tipos, ou seja, todos aqueles elementos que são úteis para distinguir determinado tipo de todos os outros tipos. Há somente um único requisito para o elemento distintivo - ele deve ser essencial no sentido de que, se ausente, não permita a recondução do contrato ao tipo legal, mas, ao contrário, faça com que ou se identifique com outro tipo, ou seja qualificado como atípico ${ }^{399}$.

Autores pátrios falam em elementos de existência do negócio jurídico, dando ênfase para a separação entre os planos da existência, validade e eficácia, construída por PONTES DE MIRANDA com base em autores alemães, mas efetivamente consagrada no direito brasileiro ${ }^{400}$. Uma maneira possível de se entender o fenômeno jurídico é por meio

${ }^{398}$ Cf. A. Cataudella, Successioni e donazioni - La donazione, in M. BeSSONE (org.), Trattato di diritto privato V, Torino, Giappichelli, 2005, pp. 5-6 e nt. 16.

${ }^{399}$ Cf. G. DE NovA, Il tipo contrattuale cit., pp. 70-78. BISCONTINI, por exemplo, afirma que a gratuidade ou onerosidade é uma distinção "acessória e acidental", que não é relevante para a determinação da distinção entre os tipos. Cita como exemplos o depósito e o mandato, que admitem modalidades gratuitas e onerosas, cf. G. BISCONTINI, Onerosità, corrispettività e qualificazione dei contratti cit., p. 31. Não se pode concordar com essa afirmação, pois o legislador é livre para alçar a gratuidade e a onerosidade a critério distintivo entre os tipos, e efetivamente o faz no caso do comodato e da locação. Não parece convincente a afirmação do autor de que esse caso seria uma "exceção" (p. 65).

${ }^{400} \mathrm{Na}$ própria Alemanha, a separação nítida entre os três planos não é usual, cf. J. P. SCHMIDT, Vida e obra de Pontes de Miranda a partir de uma perspectiva alemã - Com especial referência à tricotomia "existência, validade e eficácia do negócio jurídico", in RFDC 3 (2014), pp. 135-58, disponível em http://www.direitocontemporaneo.com/wp-content/uploads/2014/02/SCHMIDT-

VidaeobradePontesdeMirandaapartirdeumaperspectivaalema.pdf [acesso em 7 de setembro de 2015].

Segundo MOREIRA ALVES, "a observância daquela tricotomia, que para efeito de codificação se reduziria à dicotomia validade-eficácia, conduziria a discrepâncias”, na medida em que no capítulo referente à validade se trataria apenas da invalidade (nulidade e anulabilidade), e no capítulo referente à 
de uma separação entre o mundo dos fatos e o mundo do direito. Nem tudo o que ocorre na realidade prática, isto é, no mundo dos fatos, é relevante para o direito. A norma jurídica "seleciona" determinados fatos, que, quando concretizados, são alçados à categoria de fatos jurídicos por meio da incidência, que é incondicional e inesgotável, e faz com que os fatos sejam "transportados para o mundo jurídico" 401.

A norma jurídica é composta pelo suporte fático e pelo preceito. O suporte fático, hipotético ou abstrato, pode ser definido como o "enunciado lógico da norma em que se representa a hipótese fática condicionante de sua incidência", ou seja, condicionante “da existência do fato jurídico". O preceito, por sua vez, é "a parte da norma jurídica em que são prescritos os efeitos atribuídos aos fatos jurídicos" 402 .

Se presentes concretamente os chamados elementos nucleares do suporte fático hipotético, o fato passa a ter existência para o mundo do direito (enquanto fato jurídico), e ordinariamente produzirá os efeitos jurídicos previstos no preceito da norma, criando situações jurídicas. No caso dos negócios jurídicos, terá também de passar por uma espécie de filtro, um controle acerca da presença de requisitos de validade, que, em regra, condicionarão a sua eficácia ${ }^{403}$.

De acordo com a sistematização proposta por JUNQUEIRA DE AZEVEDO, todo fato jurídico precisa ocorrer em um determinado lugar e em um determinado momento no tempo. Se se trata de um ato jurídico em sentido amplo, é necessário também um agente. Tempo, lugar e agente são os elementos gerais extrínsecos, pois não são exclusivos dos

eficácia se trataria apenas de uma parcela dos seus aspectos, referente aos chamados "elementos acidentais" do negócio jurídico, cf. J. C. MOREIRA Alves, O negócio jurídico no projeto de Código Civil brasileiro Análise comparativa como o Código Civil português e 1967, in A parte geral do projeto de Código Civil brasileiro cit., p. 105.

${ }^{401}$ Sobre as questões tratadas, cf., amplamente, M. B. MELlo, Teoria do fato jurídico - Plano da existência, 14 ed., São Paulo, Saraiva, 2007, em especial, pp. 8, 20, 67, 69, 74-75 e 79.

402 Pode-se dar outro sentido à expressão "suporte fático", que é o de "suporte fático concreto", que corresponde ao "próprio fato quando materializado no mundo", cf. M. B. MELLO, Teoria do fato jurídico - Plano da existência, 14ª ed., São Paulo, Saraiva, 2007, pp. 40-41.

${ }^{403}$ Cf. A. Junqueira de Azevedo, Negócio jurídico cit., pp. 23-24 e M. B. Mello, Teoria do fato jurídico - Plano da existência cit., pp. 52-53. Segundo MELlo, trata-se de elementos nucleares do suporte fático (cerne e elementos completantes), que são "considerados pela norma jurídica essenciais à sua incidência e consequente criação do fato jurídico". 
negócios jurídicos. A eles se somam os elementos gerais intrínsecos, próprios de todo negócio jurídico, que são a forma, o objeto e as circunstâncias negociais ${ }^{404}$.

O negócio jurídico é uma categoria abstrata. Ao se descer em uma escala de abstração em direção ao negócio jurídico individualizado, passa-se por categorias mais ou menos específicas, e cada uma dessas categorias terá elementos de existência próprios: os chamados elementos categoriais, que são essenciais ou irrevogáveis quando não podem ser afastados pela vontade das partes, e "caracterizam a natureza jurídica de cada tipo de negócio". É possível identificar tais elementos, por exemplo, para cada um dos tipos contratuais, mas também para categorias mais altas na escala de abstração, tais como contratos gratuitos, onerosos, sinalagmáticos etc ${ }^{405}$.

Segundo DEL NERO, cada negócio jurídico concretamente celebrado “poderá apresentar uma série de elementos, que corresponderão, em maior ou menor grau, isomórfica ou homologamente, aos traços característicos de algum modelo jurídico negocial". Isso faz surgir o problema da qualificação dos negócios concretamente celebrados como pertencentes a um determinado tipo ${ }^{406}$.

Na doutrina italiana, verifica-se a contraposição entre dois critérios: o método da subsunção e o método tipológico. O primeiro propõe o simples cotejo entre o esquema contratual abstrato previsto pelo legislador e o contrato celebrado em concreto, a fim de se verificar se o conteúdo do contrato em concreto, entendido como o complexo das regras estabelecidas pelas partes para regular os próprios interesses, apresenta as características essenciais do esquema contratual abstrato ${ }^{407}$.

Para DE NovA, todavia, a subsunção falharia na medida em que não consegue resolver em um modo não arbitrário o problema de casos concretos intermediários para

${ }^{404}$ Cf. A. JUNQUEIRA DE AZEVEDO, Negócio jurídico cit., pp. 31-36.
${ }^{405}$ Cf. A. JUNQUEIRA DE AZEVEDO, Negócio jurídico cit., pp. 31-36.
${ }^{406}$ Cf. J. A. S. DEL Nero, Conversão substancial do negócio jurídico, Rio de Janeiro, Renovar, 2001, p. 80. Segundo o autor, "cada modelo jurídico negocial, as mais das vezes reconstruído, apresenta uma série de traços característicos". Já a qualificação jurídica de um fato será "o resultado de uma certa atividade, lógica e axiológica, em que, mediante a comparação entre elementos de fato e traços característicos de diversos modelos jurídicos, termina por afirmar-se que o fato 'corresponde' a um determinado modelo".

${ }^{407}$ Cf. A. CATAudella, Successioni e donazioni cit., pp. 5-6 e nt. 16. Segundo esse autor, o conteúdo do contrato consiste em "tutte le determinazioni in essere dalle parti per regolare i propri interessi", cf. A. Cataudella, Sul contenuto del contratto, Milano, Giuffrè, 1966, p. 18. 
cuja qualificação os traços distintivos abstratos mostram-se insuficientes ${ }^{408}$. Haveria "zonas cinzentas" entre os tipos, e os critérios de distinção baseados em uma análise diferencial nem sempre seriam aptos a resolver os problemas de qualificação postos pela prática contratual $^{409}$. Exemplos de possíveis zonas cinzentas no tema deste estudo são aquelas doações realizadas em atenção a interesses patrimoniais ou em cumprimento de deveres não jurídicos ${ }^{410}$.

Para solucionar o problema, DE Nova parte da diferença entre conceitos e tipos e propõe uma releitura das normas sobre os contratos especiais em "chiave tipologica" ${ }^{411}$. Os conceitos são fechados e rígidos. São formados por uma soma de elementos, todos necessários e em número determinado, que delimitam claramente seu âmbito de aplicação. O pertencimento ao conceito se dá em termos de alternativa - ou se pertence ou não se pertence. Já o tipo é aberto, seus dados característicos apresentam-se com intensidade variável, pois é mais um todo global do que mera soma de partes. O que o método tipológico propõe é maior flexibilidade na qualificação dos casos-limite, pois admitiria uma gradação, ou seja, um pertencimento maior ou menor ao tipo ${ }^{412}$.

O critério tipológico, todavia, vem sendo criticado por ser obscuro, pois atribui um papel determinante à intuição. Para BIANCA, a melhor maneira de lidar com as "zonas cinzentas" seria identificar qual é o limite dentro do qual a disciplina do contrato pode ser alterada sem alterar-se o tipo. E essa análise é feita de acordo com a causa concreta. As variações são compatíveis com o tipo quando os interesses perseguidos ulteriormente - as finalidades particulares da operação - pelas partes tenham caráter de complementaridade e acessoriedade com relação ao interesse principal $^{413}$. Esse critério parece ser o mais adequado para se verificar em que medida a presença de determinados interesses poderia

${ }^{408}$ Nesse sentido é o desabafo de ENGISCH de que "muitas coisas com que deparamos são de molde a irritar-nos, a afligir-nos mesmo: tal a insegurança ao realizar a 'subsunção", cf. K. ENGISCH, Introdução ao pensamento jurídico cit., p. 205.

${ }^{409}$ Cf. G. DE NOvA, Il tipo contrattuale cit., pp. 112-17. Nesses casos, a tendência é substituir os traços distintivos por critérios expressamente reconhecidos como não essenciais ao tipo.

${ }^{410}$ Cf. III.5.1, III.5.2 e III.5.3.

${ }^{411}$ LARENZ, aliás, afirma que o tipo se "oferece" como "forma de pensamento" quando "o conceito geral-abstrato e o sistema lógico destes conceitos não são suficientes por si para apreender um fenômeno da vida ou uma conexão de sentido na multiplicidade das suas manifestações, cf. K. LARENZ, Methodenlehre der Rechtswissenschaft, $6^{\text {a }}$ ed., Berlin, Springer, 1991, trad. port. J. Lamego, Metodologia da ciência do direito, $5^{\mathrm{a}}$ ed., Lisboa, Fundação Calouste Gulbenkian, 2009, p, 656.

${ }_{412}$ Cf. G. DE NovA, Il tipo contrattuale cit., pp. 122-29 e 138-39.

${ }^{413}$ Cf. C. M. BIANCA, Diritto civile III cit., pp. 476-77 e nt. 101. 
levar, ou não, à desqualificação de determinado negócio concretamente celebrado como doação, o que será examinado adiante ${ }^{414}$.

${ }^{414}$ Cf. III.5.1, III.5.2 e III.5.3. 


\section{Doação e contratos gratuitos}

\section{Relevância da noção de gratuidade e relação com outras classificações}

Concebida em oposição à onerosidade, a gratuidade normalmente é vista como um dos modos de classificação dos contratos ${ }^{415}$. Porém, conforme ScozZAFAva, onerosidade e gratuidade dizem respeito à atividade negocial de um modo geral, não se limitando ao campo contratual ${ }^{416}$. Pode-se afirmar, assim, que a ideia de gratuidade abrange também os negócios jurídicos unilaterais, como o testamento, conforme dispõe expressamente o art. 893 do Code civil em sua nova redação ${ }^{417}$.

Há quem entenda também que a noção de gratuidade é aplicável aos atos jurídicos em sentido estrito e até mesmo aos fatos naturais ${ }^{418}$, embora SCOZZAFAVA ressalte que quem "ativa" deliberadamente um fato natural para procurar a aquisição de bens a outrem invariavelmente pratica um negócio jurídico ${ }^{419}$. Segundo BETTI, as noções de onerosidade e gratuidade restringem-se aos negócios de atribuição patrimonial, e, por essa razão, não abrangem nem os negócios de destinação, como a constituição do dote, nem a renúncia, na qual a vantagem patrimonial seria apenas ocasional - a função do ato seria propriamente o desfazimento do bem ${ }^{420}$. OPPO, aliás, aponta a existência de atos "neutros", que escapam à dicotomia entre gratuito e oneroso ${ }^{421}$.

${ }^{415}$ Cf. C. M. BIANCA, Diritto civile III cit., p. 493.

${ }^{416}$ Cf. O. T. SCOZZAFAVA, La qualificazione di onerosità o gratuità del titolo, in Riv. dir. civ. 26 (1980), p. 69. Nesse sentido, cf. G. BISCONTINI, Onerosità, corrispettività e qualificazione dei contratti cit. p. 29, para quem a onerosidade abrange outros atos jurídicos além dos contratos.

${ }^{417}$ Art. 893. La libéralité est l'acte par lequel une personne dispose à titre gratuit de tout ou partie de ses biens ou de ses droits au profit d'une autre personne.

De acordo com o dispositivo, as liberalidades, que compreendem a doação e o testamento, são justamente atos mediante os quais as pessoas dispõem de seus bens a título gratuito.

${ }^{418}$ Cf. A. CATAudella, Donazione e liberalità cit., p. 271. Em sentido contrário, cf. P. Morozzo Della RocCA, Gratuità, liberalità e solidarietà cit., p. 3.

${ }^{419}$ Cf. O. T. SCOZZAFAVA, La qualificazione di onerosità o gratuità del titolo cit., pp.75-76.

${ }^{420}$ Cf. E. BETTI, Teoria generale delle obbligazioni III - Fonti e vicende dell'obbligazione, Milano, Giuffrè, 1954, pp. 67-68. Em relação aos atos de destinação, OPPO considera bastante duvidoso que possam ficar ao lado de fora da classificação como gratuitos ou onerosos, cf. G. OPPO, Adempimento e liberalità, Milano, Giuffrè, 1947, p. 294, nt. 1.

${ }^{421}$ Cf. G. OPPO, Adempimento e liberalità cit., p. 288 e 311 . O autor trata, em especial, do adimplemento de obrigação natural. Em sentido contrário, MorOzzo DELLA RocCA afirma que a contraposição entre negócios gratuitos e onerosos é necessária e exaustiva, abrangendo toda a área de negócios de disposição de interesses patrimoniais, cf. P. MOROZZO DELLA RoCCA, Gratuità, liberalità e solidarietà cit., p. 14 
Com relação à pertinência da classificação, devem ser analisadas as normas do ordenamento jurídico nas quais a diferença entre onerosidade e gratuidade é relevante. Segundo GALASSO, a gratuidade é um "conceito transversal”, traço peculiar de algumas categorias jurídicas que se manifesta em diferentes áreas do direito privado, com finalidades diversas ${ }^{422}$. Caracteriza-se por um regramento jurídico fragmentário e assistemático, focado em aspectos pontuais que visam à solução de problemas práticos bastante específicos que normalmente envolvem a redistribuição de riscos econômicos e a determinação da responsabilidade das partes envolvidas na relação jurídica. Não há um sistema jurídico gratuito de regras razoavelmente completo ${ }^{423}$.

As regras próprias para a gratuidade, segundo SCOZZAFAVA, são pautadas por um nítido favorecimento do "princípio da onerosidade das relações econômicas" pelo legislador, o que normalmente implica uma disciplina jurídica mais favorável ao sujeito que pratica o ato oneroso. Como consequência, o terceiro adquirente a título gratuito enfrenta uma disciplina jurídica mais rigorosa do que o adquirente a título oneroso ${ }^{424}$, pois o risco de perda do bem é maior (p.ex., na ação pauliana).

Na sistematização de CATAUDELLA, as regras jurídicas que levam em conta a gratuidade envolvem basicamente (i) a determinação dos limites da tutela ao terceiro adquirente, (ii) a determinação dos limites da responsabilidade das partes, e a (iii) a

${ }^{422}$ Cf. A. GALASSO, Principio di gratuità cit., pp. 214-16. O enfoque na gratuidade como critério de classificação dos contratos seria uma "velha gratuidade", cujo instrumental seria inadequado para resolver os problemas decorrentes tanto de uma "falsa gratuidade" - a inserção de interesses econômicos em instrumentos criados para veicular interesses não econômicos (cf. III.5.1) - quanto de uma "nova gratuidade" - que exprime uma coligação entre uma finalidade individual que deriva da personalidade e um dever de solidariedade constitucionalmente estabelecido (cf. III.5.2). Segundo GALASSO, a "nova gratuidade" apresenta dificuldade de enquadramento na concepção do gratuito baseada no negócio jurídico e no contrato, que acaba adquirindo um caráter profundamente artificial com a utilização inapropriada das normas de direito privado - em especial as normas sobre doação e sobre obrigações naturais (cf. III.5.3) - e uma inevitável solução "caso a caso" dos problemas concretos, que pode levar a decisões contraditórias. Também, cf. A GAlASSO - S. MAZZARESE, La gratuità come principio, in A GAlASSO - S. MAZZARESE (org.), Il principio di gratuità cit., pp. 6-10.

${ }^{423}$ Cf. A. GALASSO, Il principio di gratuità cit., pp. 205-14.

${ }^{424}$ Cf. O. T. SCOZZAFAVA, La qualificazione di onerosità o gratuità del titolo cit., pp. 69-70. Segundo CARRABBA, embora se possa afirmar genericamente que a gratuidade do título implica atenuação da responsabilidade do praticante do ato, há diferenças no que se refere a alguns contratos gratuitos típicos singularmente considerados (mandato, depósito, mútuo, comodato e doação), consistindo em uma gradativa diminuição da responsablidade conforme se aproxima da doação pura, cf. A. A. CARRABBA, Donazioni, in P. PERlingIERI (org.), Trattato di diritto civile del Consiglio Nazionale del Notariato IV - Autonomia negoziale, Napoli, ESI, 2009, pp. 13-14. 
escolha do critério interpretativo ${ }^{425}$. Como exemplo do primeiro, temos, no direito brasileiro, o art. 158, que traz critérios mais rigorosos para a anulação, por fraude contra credores, de "negócios de transmissão gratuita de bens ou remissão de dívida". Quanto ao segundo, temos o art. 392, que determina que "nos contratos benéficos, responde por simples culpa o contratante, a quem o contrato aproveite, e por dolo aquele a quem não favoreça”. Por fim, cabe mencionar o art. 114, pelo qual "os negócios jurídicos benéficos e a renúncia interpretam-se estritamente".

Enquanto critério de classificação dos contratos, a dicotomia gratuito-oneroso costuma ser examinada em contraposição à distinção entre contratos bilaterais e unilaterais (sinalagmáticos e não sinalagmáticos; contratos com ou sem prestações correspectivas) ${ }^{426}$. A ausência de sinalagma será considerada fundamental para a caracterização da doação ${ }^{427}$ por certos autores. A gratuidade, por outro lado, é aquele elemento em comum que une a doação aos demais contratos gratuitos. Para que se possa estabelecer o critério distintivo entre essas figuras, é necessário primeiro estabelecer aquilo que têm em comum.

Cabe aqui um esclarecimento terminológico preliminar. A doutrina brasileira normalmente trata os contratos bilaterais ${ }^{428}$ e os sinalagmáticos como sinônimos, embora

${ }^{425}$ A sistematização menciona também um quarto aspecto, a relevância dos motivos, que no direito italiano assume especial importância por conta dos arts. 624, 2, e 626 (testamento) e arts. 787 e 788 (doação), que trazem regras sobre o erro quanto aos motivos e sobre o motivo ilícito, cf. A. CATAUDELLA, Donazione e liberalità (1998), in Scritti sui contratti, Padova, Cedam, 1998, p. 271. Também, cf. G. BISCONTINI, Onerosità, corrispettività e qualificazione dei contratti cit., pp. 34-35 e 61-62. Esse aspecto não foi mencionando no corpo do texto, pois o CC br. não traz dispositivos próprios para os negócios gratuitos, mas disciplina o "falso motivo" (art. 140) e o motivo determinante ilícito (art. 166, III) de uma maneira geral para todos os negócios jurídicos. No caso do art. 166, III, refere-se mais propriamente aos negócios bilaterais ("comum a ambas as partes").

${ }^{426}$ A doutrina italiana fala em "corrispettivo" e "corrispettività", cf. por todos G. BISCONTINI, Onerosità, corrispettività e qualificazione dei contratti cit., passim. Os autores em língua portuguesa costumam traduzir tais expressões por "correspectivo" e "correspectividade", cf. por exemplo, J. M. ANTUNES VARELA, Das obrigações em geral I cit., pp. 404-05. A primeira palavra existe em língua portuguesa, mas a não segunda, cf. Vocabulário ortográfico da língua portuguesa da Academia Brasileira de Letras, disponível em http://www.academia.org.br/nossa-lingua/busca-no-vocabulario [acesso em 28 de outubro de 2015]. Assim, ao invés de se usar o neologismo, talvez seja preferível utilizar as palavras "correspondência" (com a ciência de que pode não ser exatamente equivalente ao termo "corrispettività" utilizado pelos italianos) ou "correlatividade” (sugestão dada pelo Prof. João Alberto Schützer Del Nero).

${ }^{427}$ Cf. II.4.2.

${ }^{428}$ É desnecessário lembrar que a diferença entre unilateral e bilateral é diversa se tomarmos por base o negócio jurídico. Nesse caso, negócio jurídico unilateral é aquele que decorre da declaração de vontade de uma só pessoa, enquanto bilateral é o negócio que se forma mediante concurso de vontades. Todo contrato, quanto à formação, é negócio jurídico bilateral, ainda que possa ser unilateral ou bilateral quanto aos efeitos, por gerar respectivamente obrigações para uma das partes ou para ambas, cf. por todos O. GOMES - A. JunQueIRA de AZEVEdo - F. P. D. C. MARino, Contratos cit., p. 84. 
se reconheça que seja possível uma diferenciação tendo em vista o nexo de reciprocidade e interdependência entre prestação e contraprestação - presente sempre nos contratos sinalagmáticos e nem sempre em todos os bilaterais ${ }^{429}$.

A doutrina italiana marca bem a diferença entre os contratos bilaterais e os sinalagmáticos (ou com prestações correspectivas), e hoje dá menos relevância à distinção entre bilaterais e unilaterais, considerada uma relíquia do CC de 1865. Prefere-se falar em contratos com prestações correspectivas ou não correspectivas, o que corresponde, grosso modo, à ideia de contratos sinalagmáticos e não sinalagmáticos.

Segundo CATAudella, a doutrina erigida sob o CC de 1865 entendia por bilaterais essencialmente o que hoje se entende por contratos com prestações correspectivas - ou sinalagmáticos. Com o desenvolvimento deste último conceito, porém, passou-se a dizer que são bilaterais, em uma acepção ampla, os contratos com prestações a cargo de ambas as partes, ainda que não exista um nexo de interdependência entre elas. Já os contratos com prestações correspectivas (ou sinalagmáticos) são aqueles nos quais existe justamente esse nexo ${ }^{430}$.

Para os objetivos deste trabalho, todavia, é desnecessário fazer a distinção ${ }^{431}$. O que deve ficar claro, entretanto, é a contraposição dessa dicotomia com a distinção entre contratos gratuitos e onerosos. Muitas vezes, a ideia de gratuidade é relacionada pela literatura à ideia de ausência de interdependência entre prestação e contraprestação ${ }^{432}$.

OPPO, por exemplo, afirma que "onerosità e gratuità sono concetti che implicano la presenza o l'assenza di una interdipendenza giuridica fra più prestazioni e ad

${ }^{429}$ Cf. O. Gomes - A. JunQueIRA DE AZEVEDO - F. P. D. C. MARino, Contratos cit., p. 84.

${ }^{430}$ CATAUDELla fala também em uma acepção restrita dos contratos bilaterais, mas que parece ser pertinente apenas nos sistemas jurídicos que contemplam a transmissão de direitos reais como efeito do contrato. Bilaterais seriam apenas aqueles contratos em que há um nexo de interdependência entre obrigações propriamente ditas, excluindo-se aqueles contratos com efeitos reais, que, ao contrário, seriam abrangindos pela noção de contrato com prestações correspondentes. Segundo essa acepção restrita, contrato bilateral é espécie e contrato com prestações correspondentes é gênero. Na acepção ampla vista no corpo do texto, a relação de gênero e espécie se inverte, cf. A. CATAUDELLA, Liberalità e donazione cit., p. 267-68. Também, cf. G. BISCONTINI, Onerosità, corrispettivittà e qualificazione dei contratti cit., Napoli, ESI, 1984, pp. 16 e 29 , especialmente.

431 As expressões "contratos bilaterais", "contratos sinalagmáticos" e "contratos com prestações correspectivas" podem ser tratadas como sinônimas; da mesma forma, contratos "unilaterais", "não sinalagmáticos" e "sem prestações correspectivas".

${ }^{432}$ Nesse sentido, expressamente, cf. L. C. PENTEADO, Doação com encargo e causa contratual cit., pp. 321-23 e nt. 101. 
integrare i quali non basta la presenza o l'assenza di una relazione meramente economica o di fatto" "433. JUNQUEIRA DE AZEVEDO, por sua vez, afirma que a distinção entre o oneroso e o gratuito está relacionada à ocorrência ou não de sinalagma genético, que se caracteriza pela "prestação e contraprestação, uma como causa da outra, por ocasião da formação do contrato". Assim, seriam onerosos os negócios que têm como elemento categorial inderrogável "o acordo sobre" esse sinalagma ${ }^{434}$.

Em que pesem esses entendimentos, apontar que a presença ou não de interdependência entre as prestações seja um critério distintivo entre os negócios gratuitos e onerosos pode levar ao risco de se confundir tal classificação com a distinção entre os contratos sinalagmáticos e não sinalagmáticos. A ideia de sinalagma, enquanto interdependência entre prestações, fica clara na disciplina legal da exceção de contrato não cumprido: "nos contratos bilaterais, nenhum dos contratantes, antes de cumprida a sua obrigação, pode exigir o implemento (sic) [adimplemento] da do outro" (art. 476) ${ }^{435}$. A onerosidade, por sua vez, diz respeito à coligação entre um sacrifício patrimonial e uma vantagem patrimonial comparáveis entre $\mathrm{si}^{436}$.

Na gratuidade há uma ausência de "equilíbrio entre direitos e deveres", isto é, inexiste "uma referência mútua entre as atribuições patrimoniais por vínculo causal ou condicional, a ponto de essas se equivalerem" ${ }^{437}$. Consiste na atribuição de vantagens

${ }^{433}$ Cf. G. OPPO, Adempimento e liberalità cit., p. 286.

${ }^{434}$ Cf. A. JUNQUEIRA DE AZEVEDO, Negócio jurídico cit., p. 36.

${ }^{435}$ Esse artigo explicita a existência, nos contratos bilaterais, de um sinalagma funcional, que se caracteriza pela "prestação e contraprestação, uma como causa da outra, não só na formação, mas também na execução do contrato". Para JUNQUEIRA DE AZEVEDO, aliás, os contratos sinalagmáticos têm justamente como elemento categorial "o acordo sobre o sinalagma funcional”, cf. A. JUNQUEIRA DE AZEVEDO, Negócio jurídico cit., pp. 35-36.

Embora o autor se refira a contratos bilaterais e unilaterais, se for feita a distinção apontada anteriormente, o sentido é de sinalagmáticos e não sinalagmáticos. Em sentido semelhante, segundo BODIN DE MORAES, sinalagmáticos são os negócios em que há "coligação jurídica existente entre os efeitos do contrato", cf. M. C. BODIN DE MORAES, Notas sobre a promessa de doação cit., pp. 7-8.

${ }^{436}$ Cf. C. M. BIANCA, Diritto civile III, p. 493, nt. 159. Segundo BISCONTINI, a onerosidade e a gratuidade exprimem uma "valutazione economica del fatto", cf. G. BISCONTINI, Onerosità, corrispettività e qualificazione dei contratti cit., p. 40. Também cf. M. A. DOMINGUES DE ANDRADE, Teoria geral da relação jurídica II - Facto jurídico, em especial negócio jurídico, 4a reimpr., Coimbra, Almedina, 1974, p. 57.

${ }^{437}$ Cf. L. C. PENTEADO, Doação com encargo e causa contratual cit., pp. 321-23 e nt. 101. ANTUNES VARELA, em relação a esse tema, aponta que a distinção entre contratos gratuitos e onerosos "anda muito associada no comum dos autores à distinção anterior (entre contratos bilateriais e unilaterais)". Todavia, "trata-se de classificações diferentes", pois enquanto esta última "atende à estrutura jurídica do contrato, assenta na articulação psicológico-jurídica estabelecida entre as obrgações que o integram”, aquela "refere-se à sua função econômica", cf. J. M. ANTUNES VARELA, Das obrigações em geral I cit., pp. 404-05. 
econômicas a outrem sem contrapartida patrimonial ${ }^{438}$. É um conceito que serve mais propriamente para identificar a qualidade da aquisição, pois exprime "considerações de ordem prevalentemente econômica". Assim, onerosos são os contratos que "geram vantagens e sacrifícios para ambas as partes" e gratuitos aqueles em que "somente uma das partes sofre o sacrifício patrimonial, enquanto a outra obtém um benefício" 439 .

CATAudella, buscando fazer uma relação de gênero e espécie entre as classificações - embora tal seja questionável em razão da diferença conceitual entre elas ${ }^{440}$ - aponta que a onerosidade e a gratuidade transcendem inclusive ao campo dos contratos, afirmando que o campo da onerosidade abrange, mas não se limita a, contratos bilaterais (no sentido usado pela doutrina italiana), que, por sua vez, abrangem, mas não se limitam a, contratos com prestações correspectivas (ou sinalagmáticos).

Em relação à gratuidade, unilateralidade e não correspondência, não seria possível traçar uma relação tão nítida entre gênero e espécie ${ }^{441}$, embora se possa afirmar com segurança que os contratos gratuitos são sempre contratos sem prestações correspectivas (ou não sinalagmáticos), na medida em que a ausência de contrapartida patrimonial indica também a ausência de contraprestação.

\section{Critérios distintivos entre a doação e os demais contratos gratuitos}

Diante desse quadro, é necessário estabelecer critérios distintivos entre a doação e os demais contratos gratuitos. Já foi visto aquilo que apresentam de semelhante: a gratuidade. De agora em diante, passar-se-á a verificar aquilo que a doação apresenta de particular. É necessário ressaltar que o CC disciplina contratos que ou são essencialmente

${ }^{438}$ Cf. G. OPPO, Adempimento e liberalità cit., pp. 288-89. OpPO menciona também um elemento subjetivo, que é a intenção de conferir tais vantagens. Nesse sentido, tem a mesma natureza do animus donandi. Enquanto este, na doação, seria a intenção de enriquecer, nos demais contratos gratuitos seria a intenção voltada à prestação própria de cada um. Podem ser feitas diversas críticas a essa concepção (animus donandi em seu sentido objetivo), o que será visto melhor adiante, cf. III.3.2. Primeiro, é criticável a ênfase dada ao elemento intencional, cuja aferição objetiva é muito difícil. Segundo, ainda que se admita a importância da vontade negocial, não fica clara a utilidade em se identificar um "tipo" de vontade específico para cada contrato, pois, no fundo, tudo seria expressão da autonomia privada.

${ }^{439}$ Cf. M. C. BODIN DE MORAES, Notas sobre a promessa de doação cit., pp. 7-8.

${ }^{440}$ Cf. G. BisCONTINI, Onerosità, corrispettività e qualificazione dei contratti cit., p. 30.

${ }^{441}$ Cf. A. CATAUdella, Liberalità e donazioni cit., p. 271. 
gratuitos, como o comodato ${ }^{442}$, ou apresentam modalidades gratuitas, como o mútuo ${ }^{443}, \mathrm{o}$ depósito $^{444}$, o mandato ${ }^{445}$ e a constituição de renda ${ }^{446}$. A modalidade gratuita do contrato de transporte também é referida, mas para exclui-la da aplicação das normas do $\mathrm{CC}^{447}$.

Além disso, a Lei $\mathrm{n}^{\circ}$ 9.608, de 18 de fevereiro de 1998, regula o "serviço voluntário", que é definido como uma "atividade não remunerada" com "objetivos cívicos, culturais, educacionais, científicos, recreativos ou de assistência social, inclusive mutualidade",448.

O art. 425 também dispõe ser "lícito às partes estipular contratos atípicos", não trazendo nenhuma limitação com relação à modalidade gratuita ou onerosa do contrato, o que permite entender, em princípio, que casos não abarcados pelos tipos legais sejam admitidos como contratos atípicos.

A doação vem definida no art. 538 do nosso CC como "o contrato em que uma pessoa, por liberalidade, transfere do seu patrimônio bens ou vantagens para o de outra". JUNQUEIRA DE AZEVEDO, partindo dessa definição, afirma serem tais elementos categoriais “a manifestação do animus donandi e o acordo sobre a transmissão de bens ou vantagens" $" 449$.

\footnotetext{
442 "O comodato é o empréstimo gratuito de coisas não fungíveis" (art. 579, primeira parte).
}

${ }^{443} \mathrm{O}$ art. 591 dispõe que "destinando-se o mútuo a fins econômicos, presumem-se devidos juros", dando a entender, a contrario sensu, que não se destinando a fins econômicos, o mútuo se presume gratuito. De todo modo, o dispositivo deixa clara a existência de duas modalidades de mútuo: o gratuito e o oneroso.

444 " O contrato de depósito é gratuito, exceto se houver convenção em contrário, se resultante de atividade negocial ou se o depositário o praticar por profissão" (art. 628, caput).

445 "O mandato presume-se gratuito quando não houver sido estipulada retribuição, exceto se o seu objeto corresponder ao daqueles que o mandatário trata por ofício ou profissão lucrativa" (art. 658).

446 "Pode uma pessoa, pelo contrato de constituição de renda, obrigar-se para com outra a uma prestação periódica, a título gratuito" (art. 803).

447 "Não se subordina às normas do contrato de transporte o feito gratuitamente, por amizade ou cortesia" (art. 736, caput).

${ }^{448}$ De acordo com o art. $1^{\circ}$, caput, "Considera-se serviço voluntário, para fins desta Lei, a atividade não remunerada, prestada por pessoa física a entidade pública de qualquer natureza, ou a instituição privada de fins não lucrativos, que tenha objetivos cívicos, culturais, educacionais, científicos, recreativos ou de assistência social, inclusive mutualidade".

De acordo com a lei, o serviço "não gera vínculo empregatício, nem obrigação de natureza trabalhista previdenciária ou afim" (art. $1^{\circ}$, parágrafo único), é "exercido mediante a celebração de termo de adesão" (art. $2^{\circ}$ ), e o prestador "poderá ser ressarcido pelas despesas que comprovadamente realizar no desempenho das atividades voluntárias" (art. $3^{\circ}$, caput).

${ }^{449}$ Cf. A. JunQueIRA DE AZEVEDO, Negócio jurídico cit., p. 35. 
Tal afirmação, com variações na sua formulação, encontra ampla ressonância na literatura brasileira consultada ${ }^{450}$. Vislumbram-se, em geral: (i) um elemento material, que consiste na transferência de bens ou vantagens do patrimônio do doador para o do donatário, muitas vezes identificada com um "enriquecimento" do donatário acompanhado pelo "empobrecimento" do doador; e (ii) um elemento intencional, denominado "liberalidade" ou animus donandi.

No CC italiano, a doação é definida no art. 769 do CC como o contrato através do qual, por liberalidade, uma pessoa enriquece outra, dispondo em favor desta de um direito ou assumindo perante ela uma obrigação. Com base nessa definição, a doutrina passou a individualizar os elementos distintivos da doação. Da definição legal, extraem-se basicamente um elemento objetivo - o "enriquecimento" -, e um subjetivo - o "espírito de liberalidade". Haveria, em princípio, uma correspondência entre os direitos brasileiro e italiano - tanto legislação quanto doutrina - ao atribuírem à doação dois traços distintivos: um material e um intencional.

CATAUDELla, com relação à definição do direito italiano, indica que o modo utilizado para definir a doação é diverso daquele utilizado em outros contratos, pois o legislador não se limita a fazer referência às prestações das partes ou ao efeito real decorrente do negócio, mas se refere a critérios que parecem fora de lugar em uma definição legal ${ }^{451}$. Tanto o "enriquecimento" quanto o "espírito de liberalidade" geram incerteza quanto ao possível objeto da doação, e o mesmo pode ser dito acerca da "liberalidade" e dos "bens ou vantagens" mencionados pelo CC brasileiro.

A atribuição precisa de significado a esses elementos tem a fundamental importância de distinguir a doação dos demais contratos, em especial aqueles que a ela se assemelham por conta da ausência de contrapartida patrimonial, isto é, os demais contratos gratuitos. A importância prática da distinção reside principalmente na aplicação das regras

${ }^{450}$ Entre muitos outros, cf. C. M. S. PEREIRA - R. FICHTNER, Instituições de direito civil III cit., pp. 246-47, O. GOMES - A. JunQueIRA DE AZEVEDO - F. P. D. C. MARINO, Contratos cit., p. 255, N. NerY JR. - R. M. A. Nery, Código Civil comentado, $8^{a}$ ed., São Paulo, RT, 2011, p. 616, A. AlviM, Da doação cit., p. 12, P. L. N. LôBo, Comentários ao Código Civil VI cit., p. 276, S. CAPANEMA DE SouZA, Comentários ao novo Código Civil VIII cit., pp. 115-16, P. T. V. SANSEVERINO, Contratos nominados IIContrato estimatório, doação, locação de coisas, empréstimo (mútuo - comodato), in M. REALE - J. H. Martins-Costa, Estudos em homenagem ao Professor Miguel Reale IV, São Paulo, RT, 2005, p. 62.

${ }^{451}$ Cf. A. Cataudella, Successioni e donazioni cit., pp. 5-6 e nt. 16. 
próprias da doação ${ }^{452}$, tendo-se em vista a severidade do regime que lhe é imposto ${ }^{453}$. A identificação desses elementos deverá ter em vista o entendimento, já mencionado, de DE NovA, segundo o qual é essencial o elemento cuja ausência não permita o enquadramento do contrato em um determinado tipo, mas determine o seu enquadramento em outro tipo legal, ou a sua qualificação como atípico. Assim, a doação, como espécie da categoria dos contratos gratuitos, em relação a eles tem algo de semelhante, que justificará a inclusão no mesmo gênero, e algo de diferente, que denotará as particularidades da espécie.

Pode-se dizer que a doutrina italiana hoje divide-se entre três correntes. A primeira, mais tradicional, e que encontra correspondência na visão prevalente no direito francês e brasileiro, faz a diferenciação com base no elemento objetivo. A segunda corrente, bem mais recente, faz a distinção com base no elemento subjetivo ${ }^{454}$. Pode ser identificada ainda uma terceira corrente, que não faz a distinção nem com base no critério objetivo, nem no subjetivo.

Dentro da primeira corrente, a doutrina francesa afirma que a doação se distingue dos demais contratos gratuitos, os contrats de bienfaisance definidos no art.

${ }^{452}$ Há quem defenda que as regras da doação consistem em uma disciplina geral aplicável, pelo menos em certos casos, aos contratos gratuitos. Segundo BESSONE, as normas em matéria de doação constituem "la lex generalis" dalla quale ricavare quella disciplina complessiva degli atti a titolo gratuito che il codice non contempla", isto é, os contratos gratuitos atípicos, cf. M. BESSONE, Adempimento e rischio cit., p. 231. Apoiando-se em CHAMPEAU, OPPO afirma que a aplicação das regras da doação aos demais contratos gratuitos dependeria da ratio da norma. Em regra, seriam aplicáveis as regras fundadas na generosidade do doador, pois esta é própria de todos os contratos gratuitos enquanto tais. Por outro lado, as regras que se fundam na diminuição patrimonial, em especial a forma solene (o autor é partidário da "primeira corrente" que desenvolveremos no corpo do texto) não seriam aplicáveis àqueles contratos cujo benefício consiste em um "serviço meramente pessoal", cf. G. OPPO, Adempimento e liberalità cit., pp. 94-95. A razão da não aplicação das regras de forma aos demais contratos gratuitos talvez tenha relação com afirmação de MALAURIE de que os demais contratos não comportam o mesmo juízo negativo porque implicam somente uma prestação de serviços. Ao contrário, na medida em que o devedor não corre o risco de se arruinar, tais contratos são vistos com bons olhos em razão de seu valor moral, pois tornam a sociedade menos materialista e desumana, cf. Ph. MALAURIE, Les successions - Les libéralités cit., pp. 146-47.

${ }^{453}$ Cf. F. M. D’ETTORE, Intento di liberalità e attribuzione patrimoniale - Profili di rilevanza donativa delle obbligazioni di fare gratuite, Padova, Cedam, 1996, p. 3, L. BozzI, Alla ricerca del contratto gratuito atipico, in Riv. dir. civ. 50 (2004), p. 218. Podem ser mencionados como exemplos disso a necessidade de forma solene, no direito italiano (art. 782), ou a forma escrita, no brasileiro (art. 541). A doação também enseja, por exemplo, a possibilidade de revogação (arts. 555 a 556), a nulidade da doação universal (art. 548) e inoficiosa (art. 550), a anulabilidade da doação do cônjuge adúltero a seu "cúmplice" (art. 550), o efeito de adiantamento da legítima na doação de ascendentes a descendentes e de um cônjuge a outro (art. 544) e o dever de colação imposto aos herdeiros (art. 2.002) sob pena de sonegação (art. 1.991). Poderiam ainda ser mencionados exemplos de outros ramos do direito, como a incidência de ITCMD, no direito tributário, e a atual discussão, no direito eleitoral, sobre a possibilidade de doações para campanhas eleitorais - art. 23 da Lei 9.504 de 30 de setembro de 1997.

${ }^{454}$ Cf. L. BozZI, Alla ricerca del contratto gratuito atipico cit., pp. 217-19. 
1.105 do $\operatorname{Code} e^{455}$, por efetuar a transmissão de um bem sem contrapartida, enquanto os demais têm por objeto a prestação a outrem de um serviço gratuito. É necessário, portanto, um empobrecimento e um enriquecimento ligados por uma relação de causalidade, o que implica a ausência de um equivalente ou contrapartida econômica ${ }^{456}$.

Entende-se que a doação tenha por objeto aqueles bens duradouros e transmissíveis, que provoquem acréscimo permanente no patrimônio do donatário através de verdadeira transferência "entre patrimônios", o que não incluiria "serviços humanos" como no caso do mandato - e nem a atribuição do uso de bens físicos que deixem sua substância intacta - como no comodato e no depósito ${ }^{457}$.

No Brasil, a questão da diminuição patrimonial do doador, com o consequente incremento patrimonial do donatário, também costuma ser levada em conta para diferenciar a doação dos demais contratos gratuitos. A doutrina nacional costuma fazer a diferença entre o contrato gratuito propriamente dito, ou de "pura liberalidade", e os contratos desinteressados. Estes últimos seriam "subespécies dos contratos gratuitos, nada apresentando de especial do ponto de vista prático, mas [que] teoricamente se distinguem dos que implicam diminuição patrimonial, como doação" ${ }^{\text {458 }}$.

Assim, nos contratos gratuitos propriamente ditos haveria "diminuição patrimonial de uma das partes em proveito da outra (como na doação)”, enquanto nos contratos desinteressados um contratante prestaria "um serviço ao outro sem nada receber em troca da prestação feita ou prometida, porém, sem empobrecer-se, ou sem sofrer diminuição no seu patrimônio" $" 459$.

A segunda corrente, que, como dito, vem ganhando adeptos no direito italiano, diferencia a doação dos contratos gratuitos com base no elemento subjetivo. A origem está na crítica acerca da possibilidade de a doação ter por objeto serviços, prestações de fazer em geral, e até de não fazer ${ }^{460}$. Essa admissão teria tornado insuficiente o critério do

\footnotetext{
${ }^{455}$ Art. 1.105. Le contrat de bienfaisance est celui dans lequel l'une des parties procure à l'autre un avantage purement gratuit.

${ }^{456}$ Por todos, cf. Ph. MALAURIE, Les successions - Les libéralités cit., pp. 146 e 177.

${ }^{457}$ Cf. J. P. DAWSON, Gifts and Promises cit., pp. 57-58.

${ }^{458}$ Cf. O. GOMES - A. JunQUeIRA DE AZEVEDO - F. P. D. C. MARINO, Contratos cit., p. 87.

${ }^{459}$ Cf. C. M. S. PEREIRA - R. FICHTNER, Instituições de direito civil III cit., p. 65.

${ }^{460}$ Especificamente sobre a doação que tenha por objeto prestações de não fazer, cf. L. PELlEGRINI, La donazione costitutiva di obbligazione, Milano, Giuffrè, 2004, pp. 143-44.
} 
enriquecimento e empobrecimento, ou a transferência de bens de um patrimônio a outro para se distinguir a doação dos demais contratos.

O problema não surge no caso dos contratos gratuitos típicos, cujo conteúdo é expressamente previsto em lei, mas sim quanto à possibilidade de as partes celebrarem contratos gratuitos atípicos ${ }^{461}$. Tratar-se-ia de verificar nestes a presença, ou não, do animus donandi ou espírito de liberalidade ${ }^{462}$. Caso este esteja presente, o contrato é qualificado como doação, e fica sujeito a todas as suas regras, inclusive de forma, que é solene no caso italiano (art. 782). Em caso de ausência do espírito de liberalidade, o contrato seria gratuito atípico, e, portanto, não ficaria sujeito à forma prescrita em lei para a doação ${ }^{463}$.

Segundo a terceira corrente, que parece estar relacionada à ideia de doação como categoria geral mencionada por SAVIGNY, não haveria distinção nem em razão do elemento objetivo nem do subjetivo, mas uma residualidade da doação, na ausência do enquadramento de determinado contrato como gratuito típico ${ }^{464}$. Nesse sentido, BODIN DE

${ }^{461}$ Não parece resolver o problema desses contratos gratuitos atípicos, por exemplo, a afirmação de CATAUDELLA de que a função econômico-social da doação se caracterizaria pela gratuidade, pela ausência de sinalagma e pela natureza da prestação, no sentido de ser necessariamente diversa das prestações próprias dos outros contratos gratuitos, cf. A. CATAUDELlA, La donazione mista, Milano, Giuffrè, 1970 , p. 130.

${ }^{462}$ Segundo PELLEGRINI, a concepção que diferenciava a doação dos demais contratos gratuitos com base na prestação (dar, no primeiro caso, ou fazer e não fazer, no segundo caso) resolvia, também com base nesse critério, o problema dos contratos gratuitos atípicos, que seriam aqueles contratos que têm por objeto prestações gratuitas de fazer e que não são expressamente tipificados em lei. Por outro lado, o entendimento de que a doação possa ter por objeto prestações de fazer poderia levar à qualificação de todos esses contratos como doação. Para o autor, não é isso que ocorre, pois o critério distintivo é o "espírito de liberalidade" (que entende como a presença de interesses não econômicos na prática do ato - cf. III.5.1). Assim, são doação os contratos gratuitos não tipificados que tenham por objeto prestações de fazer e que sejam praticados tendo em vista interesses extrapatrimoniais. São contratos gratuitos atípicos, em contrapartida, aqueles praticados por conta de interesses econômicos (que não consistem em contraprestação; caso contrário, não se poderia falar em gratuidade), cf. L. PELLEGRINI, La donazione costitutiva di obbligazioni cit., pp. 195-96 e 202-03. No mesmo sentido, para MANZINI, a tese que diferencia a doação e o contrato gratuito atípico com base na natureza da prestação não é convincente. O único elemento idôneo a operar a distinção entre as duas categorias é o "interesse sottostante (patrimoniale nel caso del contratto gratuito atipico, non patrimoniale nel caso della donazione), il cui concreto atteggiarsi risulta ovviamente indipendente dalla natura della prestazione", cf. C. MANZINI, Il contratto gratuito atipico in Contratto e impresa 3 (1986), p. 931.

${ }^{463}$ Com relação às demais regras, há quem entenda que a disciplina da doação sirva como um regramento geral para os contratos gratuitos, como visto, cf. G. OPPO, Adempimento e liberalità cit., pp. 9495.

464 Para BISCONTINI, nem o enriquecimento nem o animus donandi são idôneos para individualizar a doação. Também não se deve atribuir relevância à gratuidade. $\mathrm{O}$ que caracteriza a doação é a ausência de correspectivo ou sinalagma. Os demais contratos gratuitos típicos não seriam doação, não por uma impossibilidade lógica, mas por uma impossibilidade jurídica, pelo fato de terem na lei funções 
MORAES afirma que os demais contratos gratuitos apenas diferem da doação "por terem sido tipificados pelo legislador e exigirem outros requisitos além da ausência de contraprestação".

Segundo a autora, apoiando-se em BISCONTINI, "a doação representa uma figura residual, subsidiária, de fechamento (ipotesi di chiusura) do sistema: para fins de qualificação, não tendo o negócio contraprestação, nem podendo ser subsumido em outro tipo não correspectivo, de doação possivelmente se tratará" ${ }^{465}$. No mesmo sentido, para NERY e PENTEAdo há uma "residualidade do modelo donativo entre os diversos contratos ${ }^{466}$. A consequência dessa terceira corrente é que parece excluir a existência de contratos gratuitos atípicos, fazendo com que sejam qualificados como doação e sujeitos à sua disciplina jurídica ${ }^{467}$.

específicas caracterizadas pelo tipo de obrigação assumida por cada parte. Por outro lado, a doação é uma "fattispecie di chiusura" (ou "tipo contrattuale di chiusira"), que compreende todos os contratos não sinalagmáticos não suscetíveis de qualificação diversa. É essa ausência de correspondência (ou "corrispettività") que caracteriza a "minima unità effettuale" da doação, cf G. BISCONTINI, Onerosità, corrispettività e qualificazione dei contratti cit. pp. 162, 167 e 173, principalmente.

${ }^{465}$ Cf. M. C. BOdIN DE MORAES, Notas sobre a promessa de doação cit., pp. 7-8.

cit., p. 23.

${ }^{466}$ Cf. NERY JR. - L. C. PENTEADO, Doação pura, preliminar de doação e contratos de gestão

${ }^{467}$ Segundo BozzI, é só parcialmente correto afirmar que a ampliação do conteúdo possível da doação exclua a admissão de contratos gratuitos atípicos. Esses continuam sendo, em tese, possíveis em razão da autonomia contratual. O problema é a sua "utilidade no plano prático-operativo", uma vez que será extremamente difícil, na prática, encontrar exemplos concretos de contratos gratuitos atípicos que não sejam qualificados como doação, cf. L. BOZZI, Alla ricerca del contratto gratuito atipico cit., p. 233. 


\section{Doação indireta - reconhecimento no direito francês e no direito brasileiro}

\section{A "dessolenização" das liberalidades - doação indireta na França}

Por trás da ideia da doação como causa (direito romano clássico) ou como categoria geral (SAVIGNY) está a constatação de que um efeito análogo ao da doação pode ser conseguido através de diferentes figuras, inclusive disciplinadas expressamente pelo doador. Será deixada de lado, por ora, a possibilidade de a doação ter por objeto prestações de fazer ou não fazer. Ao pensar na ideia mais ampla do acréscimo patrimonial sem contrapartida, há no CC brasileiro (e também em outros Códigos) exemplos de figuras que parecem produzir um efeito igual, ou ao menos similar, ao da doação disciplinada no art. 538.

Exemplos comumente citados são a remissão das dívidas, a cessão de crédito e a assunção de dívida gratuitas. Trata-se, como se pode ver, de figuras que têm uma disciplina jurídica própria. Além disso, algumas podem não ser sequer negócios jurídicos, como a construção e plantação em terreno alheio, consideradas atos-fatos jurídicos, e o adimplemento do débito por terceiro não interessado, cuja natureza jurídica é controversa $^{468}$.

O problema é semelhante ao que se coloca para os contratos gratuitos atípicos. Se for reconhecido que através dessas figuras produzem-se os mesmos efeitos da doação, deve-se perguntar se são aplicáveis as suas regras jurídicas próprias. A questão não é simplesmente teórica, mas tem um caráter prático muito relevante, pois, no caso de figuras expressamente disciplinadas pela lei, surge o problema de compatibilizar ambas as disciplinas jurídicas. E isso é particularmente grave no caso da França e da Itália, em os respectivos Códigos Civis impõem à doação o requisito da forma solene, sob pena de nulidade, e não preveem a mesma exigência formal para os demais institutos.

Com relação a esse tema, BIONDI destaca que somente uma pequena parte dos atos de liberalidade efetivamente é realizado através do contrato de doação. Há tanto atos que, pela sua pequenez, fogem ao exame jurídico, quanto outros que, pelas mais variadas razões - evasão fiscal, ou para se tentar evitar as regras relativas à redução das

\footnotetext{
${ }^{468}$ Cf. A. JUNQUEIRA DE AZEVEDO, Negócio jurídico e declaração negocial cit., pp. 31-32.
} 
liberalidades ou à colação - são praticados através de outros meios para se atingir a mesma finalidade ${ }^{469}$.

O autor dá como exemplo o caso de um pai que para doar imóvel ao filho o compra com dinheiro próprio, mas em nome do filho. É a hipótese da chamada “intestazione di beni in nome altrui”, que, segundo CAREDDA, é um dos casos mais comuns de "doação indireta" apreciados pela jurisprudência italiana ${ }^{470}$. Há quem acrescente também que o desenvolvimento das técnicas bancárias característico da modernidade como transferências entre contas correntes e emissão e depósito de cheques - favoreceria sobremaneira a prática de atribuições patrimoniais gratuitas que escapam aos requisitos formais da doação ${ }^{471}$.

Uma hipótese explicativa da complexidade do direito que regula as doações tem a ver justamente com a dificuldade em se identificar aquela doação que é definida e disciplinada pelo direito enquanto tal e separá-la de outras hipóteses, que ou são disciplinadas sob denominações diversas, ou ficam à margem da regulação. A disciplina jurídica da doação seria centrada em uma contradição entre dois aspectos: (i) um juízo negativo do direito acerca das doações, impondo uma disciplina rigorosa, e (ii) o desenvolvimento, pelas pessoas sujeitas a ela, de técnicas variadas para evitá-la ${ }^{472}$.

Os juristas, para HYLAND, "habitariam" tanto o mundo do direito quanto o mundo dos fatos, e, sensibilizados pelas exigências práticas, ficariam divididos entre aplicar rigorosamente as regras formais e criar artifícios para atribuir validade a doações que, pela "letra fria" da lei, não seriam admissíveis sem atenção aos requisitos de forma ${ }^{473}$. É precisamente nesse contexto que surge, na França, a ideia de doação indireta.

Conforme visto, o art. 931 do Code Civil estabelece que as doações entre vivos serão realizadas perante o notário, e serão registradas sob pena de nulidade ${ }^{474}$. Tão logo o Code civil entrou em vigência, porém, os tribunais começaram a criar maneiras de

${ }^{469}$ Cf. B. BIONDI, Le donazioni cit., p. 8.

${ }^{470} \mathrm{Cf}$. V. CAREDDA, Le liberalità diverse dalla donazione cit., pp. 94-95.

${ }^{471}$ Cf. J. F. MONTREDON, La désolennisation des libéralités cit., p. 8.

${ }^{472}$ Cf. R. HYLAND, Gifts cit., pp. 9-10, 12, 87 e 113.

${ }^{473}$ Cf. R. Hyland, Gifts cit., pp. 10 e 114. A crítica do autor é de que essa busca de reconciliação do direito com a realidade acaba criando um complexo labirinto de regras e exceções.

${ }^{474}$ Art. 931 . Tous actes portant donation entre vifs seront passés devant notaires, dans la forme ordinaire des contrats; et il en restera minute, sous peine de nullité. 
flexibilizar essa exigência. Poucos anos após sua promulgação, foram consagradas exceções à forma solene para as doações manuais - don manuel - e as donations déguisées (que serão traduzidas como "doações simuladas") ${ }^{475}$. Depois, passou-se a reconhecer também as doações indiretas - donations indirectes.

A doutrina francesa costuma inserir esse fenômeno em um processo de désolennisation das liberalidades. Para Montredon, o repúdio ao formalismo é uma das principais características do direito contemporâneo. É um fenômeno progressivo, que se manifesta em todos os compartimentos da vida jurídica, mas que no campo das liberalidades se manifestou da maneira mais notável. E isso se deu justamente através da dissolução do formalismo com relação àquelas três modalidades de doação ${ }^{476}$.

O direito que regula as liberalidades desde D'AGUESSEAU, passando pelo Code civil, teria em vista principalmente a propriedade imobiliária e rural. Era essa propriedade, enquanto patrimônio familiar, que deveria ser protegida contra os excessos de uma gratuidade tendente à prodigalidade. E o formalismo proporcionava, ao menos, um momento de reflexão ao disponente ${ }^{477}$.

Todavia, a sociedade contemporânea, caracterizada por uma economia de mercado, passou por transformações consideráveis, por meio das quais foi se tornando crescentemente móvel e mobiliária, com o aumento da importância dada aos bens móveis. Segundo CARBONNIER, o movimento "desdenha" do formalismo, e é nesse contexto que abundam as doações "atípicas"

A flexibilização dos requisitos formais para a doação se deu principalmente em função de necessidades práticas ${ }^{479}$. A exceção à forma prescrita em lei para a doação manual, consagrada pela jurisprudência francesa, não apresenta grandes dificuldades de aceitação. Ela foi adotada expressamente em CC posteriores, como o italiano (art. 783) e o

${ }^{475}$ Cf. J. P. DAWSON, Gifts and Promises cit., pp. 119-20. Sobre o histórico do reconhecimento da validade das donations déguisées, cf. H. MÉAU-LAUTOUR, La donation déguisée en droit civil français Contribution à la théorie general de la donation, Paris, LGDJ, 1985, pp. 25-27.

${ }^{476}$ Cf. J. F. Montredon, La désolennisation des libéralités cit., pp. 5-6 e 9. Para uma visão crítica dessa ideia de "repúdio" ao formalismo, cf. III.2.3.

${ }^{477}$ Cf. J. Carbonnier, Préface, in J. Carbonnier et al., Des libéralités cit., pp. 6-7.

${ }^{478}$ No original, "le mouvement se rit du formalisme", cf. J. CARBOnNIER, Préface, in J. Carbonnier et al., Des libéralités cit., pp. 6-7.

${ }^{479}$ Cf. J. F. Montredon, La désolennisation des libéralités cit., pp. 5-6 e 9. 
brasileiro (art. 541, parágrafo único), com relação aos bens móveis de "pequeno valor" e "se lhe seguir incontinenti a tradição".

É interessante, neste ponto, trazer um dado do direito brasileiro. CARNAÚBA e REINIG, analisando a jurisprudência do nosso STJ, destacam que, embora se trate de um "formalismo de proteção", no caso da doação ele pode paradoxalmente revelar-se contraproducente. Assim, em alguns julgados, verifica-se uma tendência em mitigar o requisito da forma para a doação ${ }^{480}$, inclusive com a utilização da indeterminação do conceito de "pequeno valor".

No acórdão que julgou o REsp $155.240^{481}$, o STJ considerou válida doação consistente em depósitos mensais em dinheiro para a compra de um veículo, considerando a doação "de pequeno valor" em proporção à fortuna do doador, uma vez que este costumeiramente presenteava a donatária com bens vultosos. Nesse sentido PONTES DE MIRANDA afirmava que a modicidade no valor "não pode ser definida em termos de valor determinado", mas deve "levar em conta o nível patrimonial do doador e o do donatário", concluindo que "as doações manuais podem ser de alto custo" 482 .

Com relação às doações simuladas, segundo MONTREDON, haveria uma “mentira", pois a convenção a título gratuito, normalmente não escrita, é realizada sob o aspecto de outro ato ${ }^{483}$. A atribuição de validade a essas doações tem uma justificativa. A disciplina jurídica da doação não é particularmente favorável à sua prática, e, em especial na França, dá muita ênfase à proteção dos herdeiros necessários do doador. Ao considerar válidas as doações simuladas, a ordem jurídica não premia o doador e o donatário, mas propicia a aplicação das regras limitadoras da liberdade de dispor de seu patrimônio, assegurando a proteção dos parentes do doador.

${ }^{480}$ Cf. Cf. D. A. CARNAÚBA - G. H. L. REINIG, Nulidade da doação e conversão substancial do negócio jurídico cit., pp. 4008. No REsp 1.225.861, comentado pelos autores, a tendência é inversa. O STJ reforçou a nulidade da doação de modo a aplicar a conversão substancial do negócio jurídico (art. 170), convertendo uma doação nula por vício de forma em contrato de mútuo gratuito, cf. STJ, $3^{\mathrm{a}}$ Turma, REsp 1.225.861-RS, Rel. Min. Nancy Andrighi, j. 22.04.2014.

${ }^{481}$ Cf. STJ, $3^{\mathrm{a}}$ Turma, REsp 155.240-RJ, Rel. Min. Antônio de Pádua Ribeiro, j. 07.11.2000.

${ }^{482}$ Cf. F. C. PONTES DE MiRANDA, Tratado de direito privado XLVI cit., p. 241.

${ }^{483}$ Cf. J. F. Montredon, La désolennisation des libéralités cit., p. 53. Trata-se, segundo RAYNAUD, da dissimulação de uma doação através da prática de um ato oneroso, cf P. RAYNAUD, Les successions et les libéralités cit., p. 375. 
DAWSON, entretanto, é bastante crítico em relação ao fato de que tal solução tenha partido dos tribunais. Para o autor, quando ficou claro que as exigências formais do Código eram excessivas e as razões históricas para elas haviam desaparecido, deveria o legislador ter interferido para reduzi-las a dimensões aceitáveis ${ }^{484}$. Isso, todavia, não foi feito e, embora amparada em uma "jurisprudência centenária", o reconhecimento da validade das doações simuladas não encontra respaldo na lei ${ }^{485}$. E isso seria grave, pois enquanto a doação manual tem sua justificativa na conveniência, a doação simulada seria o reconhecimento da falsidade. Os tribunais simplesmente garantiriam que a fraude seja bem desenhada, o que seria "difícil de acreditar" em se tratando de um sistema jurídico "maduro",486.

A terceira modalidade de doações reconhecidas como exceção à forma solene no direito francês é a das doações indiretas. A diferença com relação à doação simulada é que não há simulação. Trata-se da doação realizada através de outros atos, que podem ter disciplina própria, mas também podem reunir os elementos de fundo da doação. Exemplos comumente citados no direito francês são a remissão de dívida, a renúncia, a estipulação em favor de terceiro e a emissão de um título de crédito abstrato ${ }^{487}$.

Segundo MÉAU-LAUTOUR, ao contrário da doação simulada, na doação indireta o doador não objetiva a produção de efeitos diferentes daqueles próprios do ato. O que doador busca é, simultaneamente, realizar uma doação e praticar o ato, de modo que há uma coexistência dos efeitos específicos e próprios da figura utilizada com os efeitos da

${ }^{484}$ Cf. J. P. DAWSON, Gifts and Promises cit., pp. 119-20.

${ }^{485}$ Cf. H. MÉAU-LaUtOUR, La donation déguisée en droit civil français cit., pp. 370 e 379.

${ }^{486}$ Cf. J. P. DAwson, Gifts and Promises cit., pp. 119-20. Para uma crítica às posições de DAWSON, principalmente no que se refere ao funcionalismo, cf. R. HYLAND, Gifts cit., pp. 78-85. Para MÉAU-LAUTOUR, o reconhecimento da validade das donations déguisées pode ser aceito se for entendido que o disfarce (déguisement) assume o papel da forma. A autora resolve a questão da coexistência da doação formal e das doações sem forma (também as doações indireta e manual) reconhecendo uma equivalência funcional entre a forma e a causa, cf. H. MÉAU-LAUTOUR, La donation déguisée en droit civil français cit., pp. 370 e 379 .

${ }^{487}$ Cf. P. RAYNAUd, Les successions et les libéralités cit., p. 375, Ph. MALAURIE, Les successions - Les libéralités cit., p. 222 e H. MÉAU-LAUTOUR, La donation déguisée en droit civil français cit., pp. 399-400. A menção à emissão do título de crédito abstrato como exemplo de doação indireta se dá em razão do efeito translativo da doação (art. 938 do Code). No nosso direito, que adota a separação de planos, a emissão de um título de crédito não poderia ser considerada, em si, doação indireta, da mesma forma que não poderiam ser considerados como tal o registro do título translativo ou a própria tradição. Isso se dá pois estão em plano diverso (o plano da transmissão ou constituição do direito) que é separado do plano dos negócios jurídicos que lhe dão fundamento enquanto causa (de atribuição), cf. II.5.2. 
doação. Nesse sentido, são atos que permitem a coexistência dos elementos próprios da doação, sem que isso os descaracterize ou que isso acarrete alguma contradição lógica ${ }^{488}$.

Da mesma forma que no caso das doações simuladas, o reconhecimento das doações indiretas é importante para a aplicação a tais atos das regras de fundo da doação, especialmente no que toca à proteção da legítima dos herdeiros necessários ${ }^{489}$. Por essa razão, CARBONNIER e sua equipe propuseram a inclusão de um dispositivo no $\mathrm{CC}$ fr. para disciplinar especificamente as donations atypiques, submetendo-as às regras de fundo das doações ordinárias ${ }^{490}$. Buscou-se, com isso, “oficializar" essas modalidades dotadas de "caráter sui generis", confirmando a jurisprudência que as valida e estabelecendo expressamente sua disciplina legal ${ }^{491}$.

A alteração, todavia, não foi incorporada pela lei $2006-728^{492}$, que se limitou a, timidamente, estabelecer na nova redação do art. 920 que as liberalidades "diretas ou indiretas" são redutíveis à quota disponível ${ }^{493}$, ou seja, não prejudicam a legítima dos herdeiros necessários.

\section{Reconhecimento da categoria das doações indiretas no Brasil}

No Brasil, a categoria das doações indiretas é pouco desenvolvida. A doutrina costuma mencionar figuras previstas no CC cujo efeito jurídico seria similar ao da doação, tais como a remissão das dívidas (arts. 385 a 388), a cessão de crédito e a assunção de dívida gratuitas (arts. 286 a 303) ${ }^{494}$, o adimplemento do débito por terceiro não interessado

${ }^{488}$ Cf. H. MÉAU-LAUTOUR, La donation déguisée en droit civil français cit., pp. 398-99.

${ }^{489}$ Cf. H. MÉAU-LAUTOUR, La donation déguisée en droit civil français cit., pp. 370 e 379.

${ }^{490}$ Art. 935. Les donations indirectes, les donations déguisées et les dons manuels sont soumis aux règles de fond des doantions ordinaires.

${ }^{491}$ Cf. J. CARBONNIER et al., Des libéralités cit., p. 48.

${ }^{492}$ Parte considerável das sugestões propostas pela equipe de professores que elaborou o Offre de loi não foi incorporada pelo legislador de 2006. Este, segundo MALAURIE, ao invés de reorganizar o conjunto da disciplina jurídica das liberalidades, acabou por implementar reformas parciais, algumas superficiais e outras importantes, mas sempre de maneira fragmentada, cf. Ph. MALAURIE, Les successions Les libéralités cit., p. 20.

${ }^{493}$ Art. 920. Les libéralités, directes ou indirectes, qui portent atteinte à la réserve d'un ou plusieurs héritiers, sont réductibles à la quotité disponible lors de l'ouverture de la succession.

${ }^{494}$ ANTUNES VARELA menciona também a possibilidade de a cessão da posição contratual ser realizada "no intuito de fazer uma liberalidade ao cessionário". Nesse caso, no direito português "se aplicam à cessão as prescrições de forma, as regras da capacidade, as indisponibilidades, etc. próprias da doação", cf. 
(art. 305) e a estipulação em favor de terceiro (art. 436). Outros exemplos são as construções e plantações em terreno alheio sem que haja a indenização prevista no art. 1.255, caput, e a tolerância ao decurso de prazo para aquisição de propriedade por usucapião $^{495}$.

Haveria doação indireta nos casos em que "o intento liberal do doador toma corpo em forma jurídica distinta do contrato de doação" ${ }^{496}$. Seriam conceituadas por exclusão, como "atos de liberalidade que não podem ser qualificados como doação direta, nos quais se observa o empobrecimento de um sujeito e o correspondente enriquecimento do outro" e que se concretizam através de "várias formas de transmissão de direitos" "497. Esses atos seriam isentos do "rigor da forma", que é reservado "para as doações propriamente ditas, chamadas diretas", de maneira que a eles se aplicariam, em um modo relativo, as regras da doação ${ }^{498}$. Estariam sujeitas, por exemplo, ao dever de colação (art. $2.002)^{499}$.

Alguns autores nem se preocupam em utilizar a expressão "doação indireta", mas tratam as hipóteses, simplesmente, como doação. Segundo VILLELA, haverá doação sempre que estiverem presentes os requisitos, "ainda que alguns de tais atos possam ter um

J. M. Antunes VARElA, Das obrigações em geral II cit., pp. 394-95. A base legal é um dispositivo do CC port. que dispõe:

Art. $425^{\circ}$. A forma da transmissão, a capacidade de dispor e de receber, a falta e vícios da vontade e as relações entre as partes definem-se em função do tipo de negócio que serve de base à cessão".

${ }^{495}$ Cf. A. Alvim, Da doação cit., p. 54 e J. B. Villela, Contrato de doação cit., p. 257, N. NeRY JR. - L. C. PENTEAdO, Doação pura, preliminar de doação e contratos de gestão, pp. 55-56, J. B. Villela, Contrato de doação cit., p. 257, F. C. PONTES DE MIRANDA, Tratado de direito privado XLVI cit., p. 197, L. C. Penteado, Doação com encargo e causa contratual cit., pp. 303, 306 e 380, S. S. VENOSA, Direito civil III - Contratos em espécie, $12^{\text {a }}$ ed., São Paulo, Atlas, 2012, p. 105.

${ }^{496}$ Cf. O. Gomes - A. JunQueIRA DE AZEVEDO - F. P. D. C. MARInO, Contratos cit., p. 261.

${ }^{497}$ Cf. S. S. VenosA, Direito civil III cit., p. 105.

${ }^{498}$ Cf. A. AlviM, Da doação cit., p. 54. Para AlviM, "a forma será a prescrita para tais atos, e não a exigida para a doação".

${ }^{499}$ Cf. C. M. S. Pereira - C. R. B. MoreIRA, Instituições de direito civil VI - Direito das sucessões, $16^{\mathrm{a}}$ ed., Rio de Janeiro, Forense, 2008, p. 452. VELOSO, no mesmo sentido, afirma que a "obrigação de colacionar as doações" deve ser entendida "em sentido amplo, incluindo outras liberalidades, especialmente as denominadas doações indiretas"; e completa: "o descendente tem que trazer à colação o valor da doação direta, como o da doação indireta ou dissimulada" (as donations déguisées do direito francês), o que incluiria: "remissão de dívida, compra de bem em nome do filho, construção de prédio em terreno do filho, constituição de sociedade em nome do filho, aumento do capital do filho em sociedades comerciais etc.”, cf. Z. Veloso, Comentários ao Código Civil XXI - Parte especial - Do direito das sucessões - Da sucessão testamentária; Do inventário e da partilha (Artigos 1.857 a 2.027), in A. JunQueIRA de Azevedo (coord.), Comentários ao Código Civil, São Paulo, Saraiva, 2003, pp. 412-13. No mesmo sentido, cf. C. MAXIMILIAnO, Direito das sucessões III, 2ª ed., Rio de Janeiro, Freitas Bastos, 1943, pp. 451 e 454. 
nomen iuris específico" ${ }^{\natural 00}$. NERY e PENTEADO, no mesmo sentido, afirmam ser possível concluir "que a doação admite uma qualificação relativa", isto é, que "pode ser inserida também, em meio a outros contratos"

PONTES DE MIRANDA aponta que a atribuição patrimonial pode ser feita tanto diretamente através da transferência de propriedade ou constituição de direito real, como através de outros fatos jurídicos - atos-fato, atos jurídicos stricto sensu ou outros negócios jurídicos - que aumentem o patrimônio do donatário ${ }^{502}$. PENTEADO, aliás, ressalta que a doação seria "um ato tão diferente dos outros, que pode ter seu resultado alcançado mediante atos não propriamente jurídicos". Seriam características a "elasticidade da figura e também as diferentes hipóteses e a variedade de fins nos quais pode ser utilizada", de maneira que "alguns autores chegam mesmo a anunciar categorias de atos e dizer se correspondem ou não a doações". Sua conclusão é de que "todo ato inter vivos sem uma finalidade típica pode ser feito donationis causa" ${ }^{\text {,503. }}$.

Na linha do pensamento de PONTES DE MIRANDA, não seria contraditória, de um lado, a construção da doação como um tipo contratual, e, de outro, a possibilidade de se praticar doação através de outras figuras sujeitas a uma disciplina diversa no $\mathrm{CC}$, em função da separação de planos entre o acordo e a efetiva atribuição do bem ou vantagem ao donatário $^{504}$. Segundo o jurista, o que é direta ou indireta não é a doação, mas a atribuição patrimonial. A atribuição "direta" seria através da tradição (art. 1.267) ou do registro (art. 1.245), conforme se trate de bem móvel ou imóvel. Já a atribuição “indireta” pode se dar através das mais variadas figuras. A atribuição patrimonial poderia consistir não só na "alienação da propriedade ou de direito real limitado" e na "constituição de direito real

${ }^{500}$ Cf. J. B. Villela, Contrato de doação cit., p. 257.

${ }^{501}$ Cf. N. NERY JR. - L. C. PENTEADO, Doação pura, preliminar de doação e contratos de gestão, pp. 55-56.

${ }^{502}$ Cf. F. C. PONTES DE MIRANDA, Tratado de direito privado XLVI cit., p. 197. De maneira semelhante, GOMES também admite a realização de doações indiretas através de "ato não negocial", cf. O. Gomes - A. JunqueIra de AZEVEdo - F. P. D. C. MARINO, Contratos cit., p. 261.

${ }^{503}$ Cf. L. C. PENTEADO, Doação com encargo e causa contratual cit., pp. 303 e 306.

504 PENTEADO adota perspectiva semelhante quanto à separação de planos, porém, para defender que a doação pode eventualmente não ser concebida como contrato, mas como negócio jurídico unilateral receptício, cf. I.7.1. Segundo ele, a exigência que constava do art. 857, III, do CC de 1916 segundo a qual a "transcrição" do "título de transmissão" gratuito promovida "pelo próprio transferente" deveria ser acompanhada de "prova da aceitação do beneficiado" não implicava necessariamente a contratualidade da doação, mas a bilateralidade do acordo de transmissão da propriedade que deveria ser levado a registro. Com relação a esse acordo, todavia, autor faz a ressalva de que a doação "muitas vezes o absorve", cf. L. C. PENTEADO, Doação com encargo e causa contratual cit., p. 311, nt. 74. 
limitado", mas também na assunção de dívida, na liberação de gravames, na remissão de dívida e no "pagamento de dívida do outorgado", entre outras hipóteses ${ }^{505}$.

Poderia, também, não depender de negócio jurídico, mas consistir em efeito de fatos jurídicos previstos como modos originários de aquisição da propriedade, como a confusão, comistão e adjunção ${ }^{506}$. Também poderia, segundo o autor, se dar através da destruição ou devolução de um título de crédito, ou da omissão quanto ao protesto de um título $^{507}$. Deve-se separar o ato de disposição e o negócio jurídico da doação, pois a “atividade de disposição" pode ser positiva ou negativa (omissão), e nem sempre é negócio jurídico. A doação "conclui-se com a observância das regras jurídicas concernentes à transferência do direito", que pode se dar através de negócios abstratos, os quais são elementos do suporte fático não só da doação, como de outros negócios jurídicos ${ }^{508}$.

Para PONTES DE MiRANDA, o que é necessário é que haja uma relação de causalidade entre o acréscimo patrimonial do donatário e a desvantagem patrimonial do doador $^{509}$. Por isso, não haveria doação na avulsão, aluvião ou em benfeitorias adquiridas pelo proprietário em razão da posse de má-fé, pois não "doa quem faz aumentar o patrimônio de outrem, sem que, com isso, diminua o seu". Da mesma forma, comodato não seria doação em razão da restituição do bem. Haveria doação, ao contrário, no rompimento do título de crédito para extinguir gratuitamente uma dívida e igualmente doaria o dono de

${ }^{505}$ Cf. F. C. PONTES DE MIRANDA, Tratado de direito privado XLVI cit., pp. 192-94 e 229-234.

${ }^{506}$ VILlELA traz uma interessante discussão acerca da natureza jurídica do iactus missilium, isto é, do arremesso de objetos à multidão. Conclui que será um ato de abandono (derrelição) ou oferta de doação a pessoa indeterminada conforme a intenção do iactans, a ser aferida objetivamente por meio do seu comportamento, cf. J. B. VILlELA, Contrato de doação cit., pp. 280-82.

${ }^{507}$ Cf. F. C. PONTES DE MIRANDA, Tratado de direito privado XLVI cit., pp. 192-94 e 229-234. O autor também menciona a omissão quanto ao esgotamento de um prazo prescricional ou preclusivo e quanto à interposição de recurso contra decisão favorável ao beneficiário. Porém, tais casos são problemáticos, pois não atingem o direito material propriamente dito, mas a pretensão no caso da prescrição (art. 189 do CC br.) e uma faculdade ou poder processual no caso da preclusão, cf. C. R. DINAMARCO, Instituições de direito processual civil II, $2^{\mathrm{a}}$ ed., São Paulo, Malheiros, 2002, p. 455.

${ }^{508}$ Cf. F. C. PONTES DE MIRANDA, Tratado de direito privado XLVI cit., pp. 192-94 e 229-234. PONTES DE MIRANDA dá como exemplos de negócios abstratos o "reconhecimento de dívida" ou a "entrega de título cambiário ou cambiariforme". Poder-se-ia objetar, todavia, que os fatos jurídicos mediante os quais normalmente se operam as chamadas doações indiretas não são negócios abstratos, até porque, de acordo com JUNQUEIRA DE AZEVEDO, no direito brasileiro "não há negócios absolutamente abstratos", cf. A. JUNQUEIRA DE AZEVEDO, Negócio jurídico cit., p. 143.

${ }^{509}$ Os requisitos do "empobrecimento" e do "enriquecimento" para a configuração da doação serão examinados criticamente adiante, cf. III.1 e III.2. 
um bem "que permite que outrem o apanhe para si", e o que deixa, "com vontade de alienar, que o liquido se despeje no tanque de outrem"

Por outro lado, seria necessária também a aceitação ou anuência do donatário para que as mencionadas figuras possam veicular doação, em atenção à sua natureza contratual prevista em lei. É por essa razão que, no caso do adimplemento de obrigação alheia por terceiro, segundo PONTES DE MIRANDA, deve haver a (i) renúncia deste ao direito de cobrar a dívida do devedor, e (ii) a aceitação do pagamento pelo devedor, mediante acordo prévio ou anuência posterior ${ }^{511}$. Isso ocorre porque o art. 305 prevê expressamente que o terceiro não interessado que paga a divida em nome próprio "tem direito a reembolsar-se do que pagar". Além disso, o art. 306 também dispõe que o pagamento feito "com desconhecimento ou oposição do devedor, não obriga a reembolsar aquele que pagou". O devedor não tem só o dever de adimplir, mas o direito, podendo se opor ao pagamento realizado por terceiro (cf., também, art. 304, parágrafo único).

Em suma, a doutrina brasileira, embora não muito desenvolvida no que se refere às doações indiretas, parece não encarar com grandes dificuldades o fato de que outras figuras jurídicas, inclusive previstas em lei com uma disciplina própria, possam produzir efeitos similares ao da doação. Caso estejam presentes os elementos caracterizadores desta, reconhece-se que deve haver aplicação de suas regras de fundo, ainda que não se exija a forma prescrita em lei.

Talvez essa facilidade se deva a duas razões: (i) o fato de que os requisitos formais impostos para a doação no direito brasileiro não são tão rigorosos quanto a forma solene imposta na França e na Itália ${ }^{512}$; e (ii) o fato de se adotar o sistema da separação entre o plano do direito da obrigações e plano das atribuições de direitos, que permite ver a doação como uma espécie de causa donandi justificadora da prática de variadas figuras ${ }^{513}$.

${ }^{510}$ Cf. F. C. Pontes De MiRANDA, Tratado de direito privado XLVI cit., pp. 195-96.

${ }^{511}$ Cf. F. C. PONTES DE MIRANDA, Tratado de direito privado XLVI cit., pp. 195 e 232-34. Segundo ANTUNES VARELA, "se quiser beneficiar gratuitamente o devedor, libertando o seu patrimônio do débito que o onerava, o cumprimento [pelo terceiro] constituirá uma liberalidade indireta ao beneficiário (quando este a aceite), à qual serão aplicáveis, na medida em que a analogia das situações o justifique, as regras do contrato de doação", cf. J. M. ANTUNES VARELA, Das obrigações em geral II, 7 $7^{\mathrm{a}}$ ed., $3^{\mathrm{a}}$ reimpr. (2007), Coimbra, Almedina, 1997, p. 29.

${ }_{512}$ Basta, como já mencionado, o instrumento particular (art. 541, caput), a não ser que se trate de bem imóvel com valor superior a trinta salários mínimos (art. 108).

${ }^{513}$ Assemelha-se, assim, à doação do direito romano clássico, cf. I.2.1. 


\section{Doação indireta e liberalidades diversas da doação no direito italiano}

\section{Doação indireta e negócio indireto - o CC italiano de 1865}

$\mathrm{Na}$ Itália, a doutrina da doação indireta foi construída sob a égide do CC de 1865, por influência dos juristas franceses. A base legal era o art. $1.001^{514}$, que estabelecia aos descendentes o dever de levar à colação os bens recebidos por doação "diretamente" ou "indiretamente". A redação, aliás, era semelhante à que consta do art. 24, caput, da nossa Lei 9.504 de 30 de setembro de 1997, que estabelece ser "vedado a partido e candidato, receber direta ou indiretamente" as doações que em seguida especifica. É duvidoso, entretanto, tanto no caso italiano de 1865 quanto na lei eleitoral brasileira, que a expressão "indiretamente" sirva para consagrar a categoria das doações indiretas. Parece, ao contrário, que o objetivo é evitar a fraude à lei, principalmente em razão da interposição de pessoa ${ }^{515}$, o que nenhuma relação guarda com o instituto da doação indireta.

Esta, da maneira como foi inicialmente concebida pela doutrina italiana, ocorreria em casos como a estipulação em favor de terceiro, que teriam o mesmo "efeito prático" da doação, mas não estavam sujeitos à forma solene ${ }^{516}$. Inicialmente, a construção teórica fundou-se na ideia de negócio indireto, que é um negócio voltado para ocorrência de um resultado ulterior que não é normal ou típico do próprio negócio. Esse negócio se distingue do negócio simulado, pois as partes realmente querem os seus efeitos jurídicos próprios, mas estes são instrumentais em relação ao escopo ulterior que é perseguido ${ }^{517}$.

A categoria dos negócios indiretos foi elaborada com base na ideia de que novos interesses surgem da vida prática antes que o ordenamento proporcione meios jurídicos adequados à sua satisfação. Assim, as partes acabam valendo-se de institutos e

${ }^{514}$ Art. 1.001. Il figlio o discendente il quale venga alla successione, ancorchè con beneficio d'inventario, insieme coi suoi fratelli o sorelle o loro discendenti, deve conferire ai suoi coeredi tutto ciò che ha ricevuto dal defunto per donazione sì direttamente, come indirettamente, eccettuato il caso che il donante abbia altrimenti disposto.

${ }^{515}$ A fraude à lei, assim como a simulação na nova sistemática do CC de 2002 (art. 167), pode dar ensejo à nulidade do negócio jurídico, cf. art. 166, VI: "É nulo o negócio jurídico quando: (...) tiver por objetivo fraudar lei imperativa". Assim, de certa maneira perdeu sentido a discussão que atormentava a doutrina anterior sobre as diferenças entre fraude e simulação, que tinha relevância prática em razão da sanção de anulabilidade prevista para esta última, cf. 147, II, do CC de 1916. Sobre o tema, cf. M. B. MELLO, Teoria do fato jurídico - Plano da validade, 8 a ed., São Paulo, Saraiva, 2008, pp. 99-102.

${ }_{516}$ Cf. V. CAREDDA, Le liberalità diverse dalla donazione cit., pp. 74-76.

${ }^{517}$ Cf. C. M. BIANCA, Diritto civile III cit., p. 485. 
estruturas já existentes (negócios-meio) para a perseguição de escopos e funções diversos daqueles em relação aos quais tais estruturas haviam sido criadas ${ }^{518}$.

Pensando em termos de causa (função) abstrata, não haveria alteração na causa em virtude da utilização "indireta" do negócio, o que levaria o fim ou escopo ulterior a configurar-se como simples motivo ${ }^{519}$. Trata-se de um motivo juridicamente relevante e comum entre as partes que, apesar disso, não interfere na identidade do negócio ${ }^{520}$, que permaneceria com a qualificação jurídica original.

Entendida como negócio indireto, a doação indireta estrutura-se da seguinte forma: o negócio-meio consiste nas figuras tipificadas pelo ordenamento através das quais a doação se realiza, e o escopo ulterior é a liberalidade. A disciplina jurídica é a do negócio-meio, determinada pela sua causa abstrata, e o escopo ulterior de liberalidade permanece na esfera dos motivos. Estes, excepcionalmente considerados relevantes, justificam a aplicação de algumas normas da doação em razão do resultado práticoeconômico análogo ${ }^{521}$.

O problema, porém, é que nas figuras identificadas como doação indireta, é difícil vislumbrar um escopo ou fim ulterior ou anormal, pelo simples fato de que cada uma delas já implica, por si só, como efeito jurídico típico, o favorecimento do beneficiário sem contrapartida, da mesma forma que a doação ${ }^{522}$.

Além disso, a noção de negócio indireto passou a ser criticada pela sua inconsistência. Se o escopo ulterior permanece na esfera dos motivos, sua relevância jurídica será mínima, pois alterará apenas excepcionalmente o regime jurídico do negócio original. Por outro lado, a categoria seria desnecessária com a concepção de causa

${ }^{518}$ Cf. V. CAREDDA, Le liberalità diverse dalla donazione cit., pp. 78-79.

${ }^{519}$ Cf. C. M. BIANCA, Diritto civile III cit., p. 485.

${ }^{520}$ Cf. V. CAREDDA, Le liberalità diverse dalla donazione cit., pp. 82-83. De acordo com PENTEADO, o negócio indireto caracteriza-se por ser um meio "para obter fim diverso do típico", um fim que "pressupõe o fim típico, mas vai além dele, ultrapassa-o". A função dos "negócios diretos típicos" estaria presente, mas haveria também circunstâncias que fariam do negócio concretamente considerado um "ato sui generis", cf. L. C. PENTEADO, Doação com encargo e causa contratual cit., p. 366-67 e 370-71.

${ }^{521} \mathrm{Cf}$. V. CAREDDA, Le liberalità diverse dalla donazione cit., p. 84.

${ }^{522}$ Cf. C. M. BiAnCA, Diritto civile III cit., p. 486. Além disso, no caso da doação indireta efetuada por meio de atos-fatos, como na construção ou plantação em terreno alheio, seria uma contradição em termos definir tais figuras como negócios indiretos, cf. V. CAREDDA, Le liberalità diverse dalla donazione cit., pp. 86 e 102. Sobre a incompatibilidade entre os conceitos de doação indireta e negócio indireto, ainda, cf. V. R. CASUlli, Donazioni indirette e renunzie ad eredita o legati, Roma, Foro italiano, 1950, p. 61. 
concreta, na qual deixa de haver uma rígida distinção entre causa e motivo, pois perde sentido a diferença entre a causa típica e o escopo ulterior; este deixa de ser mero motivo e passa a integrar efetivamente a função econômico-individual do negócio ${ }^{523}$.

\section{Liberalidades diversas da doação - o art. 809 do atual CC italiano}

Entre as inovações do CC italiano de 1942 em matéria de doação está a consagração legislativa das doações indiretas. Na sistemática do legislador, todavia, não se utilizam nem o termo "doação", nem o termo "indireta". A não utilização deste último é compreensível, tendo-se em vista as críticas à recondução da figura à categoria dos negócios indiretos ${ }^{524}$. Já a não utilização do primeiro é bastante significativa, pois demonstra que o legislador buscou criar uma distância conceitual e estrutural entre a doação direta e a indireta ${ }^{525}$.

A doutrina passou a se referir a liberalidades atípicas ou liberalidades diversas da doação - ou, ainda, "liberalità non donative". A expressão liberalidades atípicas, embora usada por autores como BIONDI e VECCHIO, vem sendo criticada pelo fato de que muitas das figuras identificadas como tal são "típicas", na medida em que disciplinadas expressamente pelo CC. Prefere-se, assim, falar em liberalidades diversas da doação - ou, simplesmente, liberalidades. A expressão "ato" de liberalidade, embora utilizada pela lei, também é criticada, pois a doutrina entende que o âmbito das liberalidades seria tão vasto e heterogêneo que poderia compreender não só hipóteses negociais ${ }^{526}$.

${ }^{523} \mathrm{Cf}$. V. CAREDDA, Le liberalità diverse dalla donazione cit., pp. 82-84 e C. M. BIANCA, Diritto civile III cit., pp. 485-86.

${ }^{524}$ Cf. II.6.1.

${ }^{525}$ Cf. G. VECCHIO, Le liberalità atipiche, reed.,Torino, Giappichelli, 2006, p. 11. Em matéria de colação, todavia, mantém-se redação semelhante ao antigo art. 1.001. Dispõe o art. 737 que está sujeito à colação tudo aquilo que foi recebido do de cujus por doação, "diretamente ou indiretamente" (a redação, aliás, é semelhante à do art. 24 da nossa Lei 9.504/97, que "estabelece normas para as eleições" e dispõe ser "vedado, a partido e candidato, receber direta ou indiretamente" as doações que em seguida especifica):

Art. 737, 1. I figli e i loro discendenti ed il coniuge che concorrono alla successione devono conferire ai coeredi tutto ciò che hanno ricevuto dal defunto per donazione direttamente o indirettamente, salvo che il defunto non li abbia da ciò dispensati.

${ }^{526}$ Exemplos normalmente citados são os da construção, plantação e semeadura em terreno alheio, que gera aquisição do direito de propriedade pela acessão, e a tolerância do decurso do prazo de usucapião em favor do possuidor. Exemplos de liberalidades negociais, por outro lado, são as remissões, as renúncias, o contrato em favor de terceiros, o adimplemento de débito por terceiro e a doação mista (ou negotium mixtum cum donatione) - com relação a esta última, é controversa sua colocação entre as 
O art. 809, o último da disciplina da doação, refere-se em seu título a "normas sobre as doações aplicáveis a outros atos de liberalidade" ("norme sulle donazioni applicabili ad altri atti di liberalità"). No texto, refere-se às "liberalidades" que "resultam de atos diversos daqueles definidos pelo art. 769", e afirma estarem sujeitas às mesmas normas que regulam a revogação e a redução em favor da legítima dos herdeiros necessários $^{527}$.

GATT aponta uma contradição entre a rubrica do art. 809 e o texto, pois enquanto na primeira se fala em outros atos de liberalidade, no segundo se fala em liberalidades resultantes de atos diversos da doação. Haveria, então duas noções de liberalidade: (i) a liberalidade como ato e (ii) a liberalidade como resultado do ato ou efeito. A essas se soma uma terceira noção de "liberalidade" presente no CC - a liberalidade como espírito (art. 769) ${ }^{528}$.

No CC brasileiro, aliás, também se verifica uma diversidade de sentidos dessa palavra. A referência a "liberalidade" é feita dezesseis vezes no CC br., com três sentidos diferentes. Nos arts. 539, 549, 556, 1.674, 2.003, par. ún., 2.004, caput e $\S 1^{\circ}$, 2.005, par. ún., 2.006 e 2.007 , caput, e $\S \S 1^{\circ}$ e $2^{\circ}$, seu sentido é nitidamente sinônimo de doação ${ }^{529}$. Nos arts. 137 e 1.911 (“ato de liberalidade”), o termo é utilizado da mesma forma que no direito francês, como gênero que abrange tanto a doação quanto o testamento. Nos arts. 538 e 540, por sua vez, a liberalidade é o elemento intencional ou subjetivo da doação, também chamado de animus donandi.

No caso do art. 809 do Código italiano, a redação utilizada pelo legislador, principalmente o título, dá a entender que existe um gênero dos atos de liberalidade, dentro do qual se incluem a doação e outros atos, cujo resultado econômico é análogo ao da

liberalidades, cf. V. CAREDDA, Le liberalità diverse dalla donazione cit., pp. 115-16 e 196 (dadas a complexidade e peculiaridade do tema, fica fora do âmbito desta tese, cf. nt. 1, supra).

${ }^{527}$ Art. 809, 1. Le liberalità, anche se risultano da atti diversi da quelli previsti dall'articolo 769, sono soggette alle stesse norme che regolano la revocazione delle donazioni per causa d'ingratitudine e per sopravvenienza di figli nonché a quelle sulla riduzione delle donazioni per integrare la quota dovuta ai legittimari.

${ }^{528}$ Cf. L. GATT, Le liberalità I, Torino, Giappichelli, 2002, pp. 6 e 22-25.

${ }^{529}$ Esse sentido de liberalidade como sinônimo de doação também está presente em alguns dispositivos do CC italiano. 
doação ${ }^{530}$. A categoria, da maneira como foi elaborada na Itália, não inclui entre os atos de liberalidade o testamento, conforme a dicotomia adotada pelo Code civil $^{531}$, mas efetivamente engloba aqueles atos que anteriormente eram tidos como doação indireta. A Exposição de Motivos ao CC de 1942 diz pouco a respeito do art. 809, limitando-se a afirmar que tal dispositivo disciplina as "così dette donazioni indirette", isto é, aquelas liberalidades "compiute senza porre in essere un contratto di donazione". Afirma ainda que a sua definição "è connessa" à de doação dada pelo art. $769^{532}$.

O CC italiano, da mesma forma que a jurisprudência francesa construída em tema de doação indireta, buscou conferir validade a atribuições de vantagens sem contrapartida que fossem realizadas por meio diverso da doação com forma solene prevista no art. 782 do CC italiano. Todavia, segundo GATT, isso criou um problema de ordem lógica, pois se tem a impressão de que o direito proporcionou dois meios jurídicos diversos para a satisfação de um mesmo interesse ${ }^{533}$, um sujeito à forma solene e outro não, o que torna difícil e contraditório aceitar que ambos convivam no mesmo sistema jurídico ${ }^{534}$. Se a ordem jurídica previu um instrumento para a realização de um determinado interesse, sob forma solene como requisito de validade, ela impôs um limite à autonomia privada. Parece inadmissível, como consequência, se considerar válida a realização do mesmo interesse através de um instrumento diverso, isento dos requisitos formais. O direito, ao fazê-lo no art. 809, parece negar a própria função legislativa de impor regras cogentes ${ }^{535}$.

Em razão disso, a proposta seria entender as liberalidades diversas da doação, não como um gênero de atos que corresponda a um interesse merecedor de tutela, mas como um tipo de efeito equivalente àquele que deriva do contrato de doação, que seria o

${ }^{530}$ Cf. U. CARNEVALI, Liberalità (atti di), in ED 14 (1974), pp. 215-16. Essa afirmada relação de gênero e espécie entre liberalidade e doação fica mais evidente com a disciplina da doação remuneratória e das liberalidades em conformidade aos usos, em que o legislador, em relação às primeiras, afirma que "non costituisce donazione la liberalità", e em relação às segundas que "è donazione anche la liberalità":

Art. 770, 1. È donazione anche la liberalità fatta per riconoscenza o in considerazione dei meriti del donatario o per speciale rimunerazione. 2. Non costituisce donazione la liberalità che se suole fare in occazione di servizi resi o comunque in conformità agli usi.

${ }^{531}$ Cf. II.5.1.

${ }^{532}$ Cf. D. GRANDI, Relazione del ministro Guardasigilli al Codice Civile cit., no 385, p. 80.

${ }^{533}$ A referência a interesse parece ser no sentido de causa-função abstrata, ou interesse merecedor de tutela (art. 1.322), cf. II.2.2.

${ }_{534}$ Cf. L. GATT, La liberalità I cit., pp. 19-20.

${ }^{535}$ Cf. L. GATT, Onerosità e liberalità, in Riv. dir. civ. 49 (2003), pp. 655-69. 
resultado econômico de enriquecimento sem contrapartida ${ }^{536}$. Isso simplificaria o problema, pois torna-se desnecessária a identificação de uma categoria abstrata com uma função própria. Singelamente, reconhecer-se-ia a necessidade de sujeitar alguns atos jurídicos a algumas normas que regem as doações, em razão da produção de um efeito análogo 537 .

Outro problema que se coloca com relação às liberalidades diversas da doação é a exigência do animus donandi para configurá-las. Podem ser identificadas duas correntes, uma que entende que basta um efeito análogo ao da doação objetivamente considerado para que estejam caracterizadas, e outra que entende ser necessária a identificação da presença do elemento subjetivo do animus donandi para a sua configuração.

A relevância prática da diferença entre essas concepções é evidente. Se o animus donandi é desnecessário, todas aquelas figuras, inclusive com disciplina legal própria (como a remissão de dívida e a estipulação em favor de terceiro) seriam consideradas atos de liberalidade por produzirem efeito análogo ao da doação, estando sempre sujeitas às normas do art. 809. Caso se entenda necessário o requisito subjetivo, por outro lado, isso nem sempre ocorrerá, mas somente nos casos em que tais atos tenham sido praticados animo donandi ${ }^{538}$.

Nesse sentido, OPPO dizia que "non si può parlare di liberalità compiuta (...) senza spirito di liberalità: la contraddizione non lo consente" ${ }^{, 539}$. BIONDI, que negava a relevância do animus donandi para a caracterização da doação, o considerava relevante para qualificar justamente as liberalidades diversas do contrato de doação, pois retomaria a

${ }^{536}$ Cf. L. GATT, Onerosità e liberalità cit., pp. 655-62. A autora é adepta da primeira corrente mencionada em II.4.2, que funda a distinção entre a doação e os demais contratos gratuitos na natureza da prestação.

${ }^{537}$ Cf. A. CAtaudella, Donazione e liberalità cit., p. 274. A nós parece que a visão não resolve o problema da técnica legislativa do $\mathrm{CC}$, que efetivamente concebeu as liberalidades como um gênero de atos dos quais a doação formal seria apenas uma espécie, como se pode ver a partir da rubrica do art. 809.

${ }^{538} \mathrm{O}$ art. $863^{\circ}, 2$, do CC port., que trata da remissão de débito, dispõe: “Quando tiver o caráter de liberalidade, a remissão por negócio entre vivos é havida como doação, na conformidade dos artigos $940^{\circ}$ e seguintes". Segundo ANTUNES VARELA, o preceito dá margem a que se conclua que "a remissão pode ter ou não ter o caráter de liberalidade". Se for feita com animus donandi, ficará sujeita inclusive às regras "de forma, de capacidade, de revogação e de disponibilidade próprias das doações”, cf. J. M. ANTUNES VARELA, Das obrigações em geral II cit., pp. 246-50.

${ }^{539}$ Cf. G. OPPO, Adempimento e liberalità cit., pp. 78-79. 
função que tinha no direito romano como causa de atribuição de direitos ${ }^{540}$. Por outro lado, GATT entende que o elemento subjetivo não constitui parâmetro válido para o estabelecimento de um conceito técnico de liberalidade; se há uma intenção liberal, ela seria irrelevante juridicamente até mesmo como motivo determinante ${ }^{541}$. O debate permanece aberto e a discussão, logicamente, dependerá do conceito de animus donandi que se adotar (cf. III.3, III.4 e III.5).

${ }^{540}$ Cf. B. BIONDI, Le donazioni cit., pp. 94-95 e 101.

${ }^{541}$ Cf. L. GATT, Le liberalità I cit., pp. 6 e 22-25 e L. GATT, Onerosità e liberalità cit., pp. 662-69. Para a autora, a função concreta ou causa em sentido objetivo serve para determinar a qualificação jurídica de determinado contrato e deve ser um elemento suficiente para justificar, de forma exclusiva, todos os efeitos que dele derivam. Um contrato diverso da doação já teria uma causa própria, que não seria a liberalidade e teria o condão de justificar os seus efeitos (pp. 655-62). Menos enfático que GATT, CHECCHINI afirma que cada um dos atos de liberalidade tem uma causa típica que não coincide com a da doação, o que significa que o reconhecimento de seus efeitos jurídicos essenciais independe do espírito de liberalidade, cf. A. CHeCCHINI, L'interesse a donare, in Riv. dir. civ 22 (1976), pp. 302-03. 


\section{CAPÍTULO III - ENRIQUECIMENTO E ANIMUS DONANDI - ELEMENTOS CARACTERIZADORES DA DOAÇÃO?}

O capítulo anterior, como visto, foi dedicado à identificação dos elementos caracterizadores da doação, e que a distinguem de outras figuras jurídicas. Parte-se do pressuposto de que a doutrina majoritária identifica um elemento objetivo (o "enriquecimento") e um elemento subjetivo (o animus donandi) para a sua caracterização. O objetivo deste Capítulo III será questionar ambas as noções, tratando, por conseguinte, de dois grandes temas. Os tópicos III.1 e III.2 serão dedicados ao elemento objetivo. Será problematizada a noção de enriquecimento como elemento caracterizador da doação no direito romano e no direito moderno, e discutida a possibilidade de a doação ter por objeto prestações de fazer. Os tópicos III.3, III.4 e III.5 serão dedicados ao animus donandi. Serão tratadas as suas diferentes concepções, a sua relevância ou irrelevância, sua relação com a causa, com a forma e com os diferentes interesses que podem levar as partes a praticar o negócio. 


\section{Elemento objetivo da doação - enriquecimento e empobrecimento}

\section{Doação entre os cônjuges no direito romano}

WINDSCHEID apontava a existência de dois conceitos de doação - um mais amplo e um mais restrito. Doação em sentido amplo seria toda atribuição patrimonial não testamentária que provoca o aumento no patrimônio do beneficiário e cuja causa determinante para o doador, aceita pelo donatário, é a intenção de aumentar o patrimônio do beneficiário. Em sentido restrito, seria doação somente a atribuição patrimonial que também provoca uma diminuição correspondente no patrimônio do doador ${ }^{542}$.

Esse duplo conceito de doação, construído com base nas fontes romanas, deuse por uma razão bastante peculiar. Além das proibições contidas na lex Cincia, um aspecto relevante no tratamento jurídico da doação no direito romano foi a proibição da doação entre os cônjuges ${ }^{543}$.

A doutrina discute quando se iniciou essa proibição, uma vez que ao tempo da lex Cincia seguramente a doação entre os cônjuges não só era permitida como os esposos eram incluídos entre aquelas personae exceptae cujas doações não precisavam respeitar o limite máximo imposto pela lei ${ }^{544}$. Permanece ainda não solucionada a questão acerca de como em relativamente pouco tempo passou-se da permissão absoluta para a proibição absoluta. Prevalece a opinião de que a proibição foi expressamente reconhecida com a lex Iulia et Papia Poppaea, do tempo de Augusto ${ }^{545}$. Para ARCHI, a vedação provavelmente não teria sido introduzida pela lei, mas apenas reconhecida por ela, uma vez que um

${ }^{542}$ Cf. B. WINDSCHEID, Lehrbuch des Pandektenrechts, 1900, trad. it. C. FADDA e P. E. BENSA, Diritto delle Pandette II-II, Torino, UTET, 1904, pp. 5-8: "Donazione in senso lato è ogni attribuzione non testamentaria di carattere patrimoniale, per la quale: a) Il patrimonio del ricevente viene accresciuto; b) la cui causa determinante è per chi la compie l'intenzione di aumentare il patrimonio del ricevente; e che, c) dal ricevente è accettata come fatta con questa intenzione. In senso stretto è donazione soltanto quella attribuzione patrimoniale della indicata specie, per la quale ad un tempo il patrimonio del donante vien diminuito in maniera corrispondente".

${ }^{543}$ Cf. I.7.2.

${ }^{544}$ Cf. Paul, 71 ad ed., F. V. 302: "Excipiuntur et adfinium personae ut privignus privigna, noverca vitricus, socer socrus, gener nurus, vir et uxor, sponsus sponsa" (= "São excetuadas também as pessoas afins, como o enteado e a enteada, a madrasta e o padrasto, o sogro e a sogra, o genro e a nora, o marido e a mulher, o noivo e a noiva").

${ }^{545}$ Cf. P. GIUNTI, Donazione (storia del diritto romano) cit., p. 170 e B. BIONDI, Donazione (diritto romano) cit., p. 228. 
fragmento do Digesto afirma que a regra tem origem nos costumes ${ }^{546}$. Para BIONDI ${ }^{547}$ e TALAMANCA $^{548}$, todavia, seria difícil vislumbrar como tal proibição diametralmente oposta ao disposto na lex Cincia teria se desenvolvido consuetudinariamente.

De todo modo, a contribuição dos fragmentos referentes à doação inter virum et uxorem para a delineação do conceito de donatio foi consideravelmente menor, haja vista que o ponto central da proibição é o binômio enriquecimento-empobrecimento (locupletatio-depauperatio $)^{549}$. Isso significa que eram proibidos entre os cônjuges aqueles atos que provocam um empobrecimento do doador com o enriquecimento do donatário, mas nem sempre esses atos coincidiam com o conceito romano de donatio ${ }^{550}$. Se, por um lado, nem tudo que é definido pelas fontes como donatio entra na proibição, por outro, são proibidos atos que claramente não são tidos como doação ${ }^{551}$.

Dois exemplos interessantes de atos expressamente qualificados como doação, mas excluídos da proibição, são a donatio sepulturae causae e a renúncia à herança donationis causa. No primeiro caso, admite-se que um cônjuge possa doar ao outro um local destinado à sepultura, pois como a coisa se tornará religiosa ${ }^{552}$, não haverá enriquecimento do donatário ${ }^{553}$. No segundo caso, a renúncia à herança causa donationis

${ }^{546}$ Cf. G. G. ARCHI, Donazione (diritto romano) cit., p. 942 . Ulp. 32 ad Sab., D. 24, 1, 1: "Moribus apud nos receptum est, ne inter virum et uxorem donationes valerent..." (= "Está admitido entre nós através dos costumes que não sejam válidas as doações entre marido e mulher...”).

${ }^{547}$ Cf. B. BIONDI, Donazione (diritto romano) cit., p. 228.

${ }^{548}$ Cf. M. TALAMANCA, Istituzioni di diritto romano cit., p. 775.

${ }^{549}$ Cf. G. G. ARCHI, Donazione (diritto romano) cit., p. 942-43.

${ }^{550}$ Cf. B. BIONDI, Donazione (diritto romano) cit., p. 228.

${ }^{551}$ Cf. G. G. ARCHI, Donazione (diritto romano) cit., p. 942 e B. BIONDI, Donazione (diritto romano) cit., p. 228.

${ }^{552}$ Cf. Ulp. 32 ad Sab., D. 24, 1, 5, 8: "Concessa donatio est sepulturae causae; nam sepulturae causa locum marito ab uxore, vel contra posse donari constat; et si quidem intulerit, faciet locum religiosum..." (="Está admitida a doação por causa de sepultura; porque consta que, por causa de sepultura pode-se doar pela mulher um lugar ao marido, ou ao contrário; e se verdadeiramente houver feito um enterro, o lugar se tornará religioso...”). Os túmulos no direito romano eram res religiosae, espécie das res extra commercium divini iuris, cf. T. MARKY, Curso elementar de direito romano, $8^{\mathrm{a}}$ ed., São Paulo, Saraiva, 1996 , p. 40.

${ }^{553}$ Cf. Ulp. 32 ad Sab., D. 24, 1, 5, 8: “... Hoc autem ex eo venit, quod definiri solet, eam demum donationem impedire solere, quae et donantem pauperiorem, et accipientem facit locupletiorem; porro hic non videtur fieri locupletior in ea re, quam religioni dicavit..." (= "Mas isso provém do que se costuma dizer, que se costuma proibir somente aquela doação que faz mais pobre o doador, e mais rico o que a recebe; porém, em verdade, não se considera neste caso que se faça mais rico com coisa que dedicou à religião..."). 
em favor da esposa não implica empobrecimento do doador, pois "não se torna mais pobre quem não adquire, mas quem gastou do seu patrimônio" 554 .

Já houve quem entendesse, por conta desses fragmentos, que o direito romano conheceu dois conceitos de doação: um mais amplo, que prescindiria da locupletatiodepauperatio, e outro mais restrito, que a exigia. Todavia, para BIONDI ${ }^{55}$, não há um duplo conceito de doação nas fontes, mas diversos pontos de vista acerca de um mesmo fenômeno. ARCHI ${ }^{556}$ é ainda mais enfático, e sustenta que há apenas um conceito de donatio nas fontes romanas, que prescinde do enriquecimento-empobrecimento. Segundo este autor, claramente se percebe que o enriquecimento do donatário acompanhado pelo empobrecimento do doador não é elemento essencial da doação romana, mas somente para haver a proibição da donatio inter virum et uxorem $^{557}$.

Esse dado da doação no direito romano contrasta com o direito moderno, no qual, talvez até mesmo por influência das fontes romanas no que toca à doação entre esposos, o enriquecimento e o empobrecimento são normalmente vistos como essenciais para a configuração da doação.

\section{Transferência de bens ou vantagens - art. 538 do CC brasileiro}

O CC brasileiro não fala explicitamente em enriquecimento e empobrecimento, mas menciona no art. 538 como elemento essencial da doação a "transferência de bens ou vantagens". Para que haja doação, PONTES DE MIRANDA afirma que é necessária a transmissão da "propriedade em sentido amplo". Isso significa que podem ser objeto da doação o domínio, direitos reais sobre coisa alheia como o usufruto, uso, habitação ou enfiteuse, qualquer direito real de garantia, e até mesmo títulos de crédito. Segundo o

${ }^{554}$ Cf. Ulp. 32 ad Sab., D. 24, 1, 5, 13: "Si maritus heres institutus repudiet hereditatem donationis causa, Iulianus scripsit libro septimo decimo digestorum donationem valere: neque enim pauperior fit, qui non adquirat, sed qui de patrimonio suo deposuit..." (= "Se o marido herdeiro repudiar a herança por causa de doação, escreveu Juliano no livro décimo sétimo do Digesto que a doação vale: porque não se torna mais pobre quem não adquire, mas quem gastou do seu patrimônio...").

${ }_{555}$ Cf. B. BIONDI, Donazione (diritto romano) cit., pp. 228-29.

${ }_{556}$ Cf. G. G. ARCHI, La donazione cit., p. 79-80.

${ }^{557}$ Cf. G. G. ARCHI, La donazione cit., pp. 78-79. 
autor, "não importa o que se doa", desde que "o direito seja alienável e transmissível à pessoa a quem se doa" ${ }^{, 558}$.

VillelA, em sentido semelhante, destaca que "o objeto do negócio é inespecífico", na medida em que o art. 538 fala, amplamente, em "bens ou vantagens". A única exigência seria implicar "proveito para o destinatário", podendo-se falar em "coisas ou direitos", tais como "dinheiro, joias, livros, peças de vestuário, obras de arte etc., ou créditos, direitos de propriedade intelectual, ações, cotas etc" $" 559$.

À primeira vista, portanto, parece que o objeto da doação é suficientemente amplo a ponto de abranger todo bem ou direito. Porém, para a literatura nacional de modo geral $^{560}$, não basta "que o beneficiado obtenha uma vantagem, um bem no seu mais amplo sentido", pois é necessário que essa vantagem tenha "natureza patrimonial" ${ }^{151}$ e que haja o "aumento de um patrimônio à custa do outro", com um nexo de causalidade entre o enriquecimento e o empobrecimento ${ }^{562}$.

Os requisitos do enriquecimento e do empobrecimento, ausentes do texto legal, retornam por força da doutrina. Nesse sentido, NERY e PENTEADO destacam que a doação pressupõe "um efetivo enriquecimento do donatário correlato a um empobrecimento do doador", e que é "necessária a verificação de efetivo deslocamento de bens do patrimônio de um para o patrimônio do outro",563.

PONTES DE MiRANDA igualmente destaca que é necessária uma atribuição patrimonial que provoque "o enriquecimento de um figurante, com diminuição patrimonial

${ }^{558}$ Cf. F. C. PONTES DE MIRANDA, Tratado de direito privado XLVI cit., pp. 191-94.

${ }^{559}$ Cf. J. B. VILlELA, Contrato de doação cit., pp. 257-58.

${ }^{560}$ Cf. O. Gomes - A, J, Azevedo - F. P. D. C. MARino, Contratos cit., p. 255, C. M. S. PEREIRA - R. FiCHTNER, Instituições de direito civil III cit., pp. 246-47, N. RosenVALD, Arts. 481 ao 652 Contratos (em espécie) cit., p. 424.

${ }^{561}$ VILLELA pontua que, embora a patrimonialidade (suscetibilidade de apreciação econômica) seja uma "orientação geral" da família romano-germânica, é, a rigor, "produto do direito positivo", "não sendo impensável" que a doação "se construísse de outro modo", cf. J. B. VILlELA, Contrato de doação cit., pp. 257-58.

${ }^{562}$ ALVIM, em relação à expressão "bens e vantagens", afirma que embora pareça "alargar o conceito de doação", "não há tanta amplitude como daí parece decorrer", cf. A. AlviM, Da doação cit., p. 11.

${ }^{563}$ Cf. N. Nery JR. - L. C. PENTEAdO, Doação pura, preliminar de doação e contratos de gestão cit., p. 24. Já afirmava BEVILÁQUA que "a doação importa em diminuição do patrimônio do doador e consequente enriquecimento do donatário. Faltando qualquer destes dois requisitos, o ato deixará de ser uma doação", cf. C. BeviláQuA, Direito das obrigações, Salvador, Magalhães, 1896, p. 246. Também cf. C. Beviláqua, Código Civil dos Estados Unidos do Brasil commentado IV, Rio de Janeiro, Francisco Alves, 1917, p. 333 e J. M. CARVAlho SANTOS, Código Civil brasileiro interpretado XVI - Direito das obrigações (arts. 1.122 - 1.187), 9a ed., Rio de Janeiro, Freitas Bastos, 1964, p. 323. 
do outro", constituindo este o "elemento-efeito" do contrato. Para que se configure a doação, ambas as "alterações" - enriquecimento e empobrecimento - são necessárias: "não pode uma existir sem que a outra exista", pois deve haver "causalidade" entre a diminuição e o aumento de patrimônio ${ }^{564}$.

Em razão da menção à "transferência", e à exigência pela doutrina do enriquecimento e do empobrecimento, uma questão que se pode colocar é acerca da possibilidade de a doação ter por objeto serviços ${ }^{565}$ e prestações de fazer (ou até mesmo de não fazer). O "fazer" é incompatível com as ideias de "transferência" e de "enriquecimento-empobrecimento"? Essa questão será analisada mais a fundo em III.2, ao tratarmos da doutrina italiana. Por ora, é importante enquadrar a questão no âmbito do direito brasileiro.

A formulação ampla do art. 538 - "bens ou vantagens" - certamente dá margem à questão. Ainda que não houvesse referência às "vantagens", o art. 83, II, do CC dispõe que se consideram bens "móveis para os efeitos legais" os "direitos pessoais de caráter patrimonial e as respectivas ações", não estabelecendo nenhuma limitação ou restrição para que se entenda que um direito de crédito tendo por objeto uma prestação de fazer possa ser um “bem ou vantagem” para efeitos de doação.

A doutrina, porém, é ambígua. O maior exemplo parece vir do próprio redator do anteprojeto que deu origem ao atual livro que trata do direito das obrigações. Na exposição de motivos complementar, ALVIM defendia a manutenção da anterior referência aos bens e vantagens (a expressão já constava do art. 1.165 do CC de 1916) - considerada uma "fórmula elástica" - por conta do reconhecimento pelos "civilistas, mormente os monografistas estrangeiros", de que a doação abarcaria "uma série de figuras jurídicas", entre elas os "serviços gratuitos" 566 . Em sua obra dedicada ao tema, todavia, primeiro

${ }^{564}$ Cf. F. C. Pontes DE MIRANDA, Tratado de direito privado XLVI cit., pp. 191-96. Segundo o autor: "Quem doa sofre com a doação. Quem dá, sem que aumente o patrimônio de outrem, não doa. Nem doa quem faz aumentar o patrimônio de outrem, sem que, com isso, diminua o seu".

565 "Serviço", aqui, é entendido num sentido amplo, como sinônimo de qualquer prestação de fazer, e não no sentido restrito adotado pelo art $3^{\circ}, \S 2^{\circ}$, do CDC: "atividade fornecida no mercado de consumo, mediante remuneração, inclusive as de natureza bancária, financeira, de crédito e securitária, salvo as decorrentes das relações de caráter trabalhista".

${ }^{566}$ Cf. A. AlviM, Exposição de motivos complementar do Prof. Agostinho Neves de Arruda Alvim, in L. C. B. RANGEL - C. A. S. LOPES (org.), Código Civil: anteprojetos V-II-Anteprojeto de Código de Código Civil - revisto (1973), Brasília, Senado Federal - Subsecretaria de Edições Técnicas, 1989, p. 44. 
afirma que "os serviços gratuitos não constituem doação", para acrescentar logo em seguida que "essa doutrina é insustentável", salvo em "caso excepcional, de trabalhos que acarretam empobrecimento, porque impedem outros lucros" ${ }^{\$ 567}$.

Entre os autores que demonstram alguma abertura às doações de fazer estão Gomes, Penteado e Pontes de Miranda. O primeiro, após afirmar que "o contrato de prestação de serviço é oneroso", aponta que "se gratuito o serviço prestado, ter-se-á doação ou contrato atípico", mas não desenvolve a ideia ${ }^{568}$. O segundo, ressaltando uma tendência em se diferenciar a doação dos demais contratos gratuitos, inclusive o serviço voluntário, aponta que a prestação de serviços gratuitos poderia ser doação se o prestador "adquire um crédito ao qual renuncia, ou que deixa inerte" ${ }^{\$ 56}$. PONTES DE MIRANDA, por sua vez, admite a doação de serviços se o beneficiário já iria "pagar despesas" e o prestador as afastou "com seu ato",570.

No caso desses dois últimos autores, fica bastante claro que a doação não consistiria propriamente na prestação do serviço, mas na renúncia à contraprestação ${ }^{571}$, tanto que PONTES DE MiRANDA, em outra passagem, afirma que não há doação na atribuição do uso de um bem ou na promessa de serviços próprios ou de terceiro; é preciso que haja "atribuição patrimonial" 572 .

${ }^{567}$ Cf. A. AlviM, Da doação cit., pp. 8 e 16-17.

${ }^{568}$ Cf. O. GOMES - A. JunQUEIRA DE AZEVEDO - F. P. D. C. MARINO, Contratos cit., p. 356.

${ }^{569}$ Cf. L. C. PENTEADO, Doação com encargo e causa contratual cit., pp. 308-09. O serviço voluntário é definido pelo art. $1^{\circ}$ da Lei 9.608, de 18 de fevereiro de 1998.

${ }^{570}$ Cf. F. C. PONTES DE MIRANDA, Tratado de direito privado XLVI cit., pp. 195-96.

${ }^{571}$ Não é pacífico o entendimento de que a remissão da dívida seria uma "particular espécie de renúncia”, pois o art. 385 do CC br. exige a aceitação pelo devedor, cf. C. M. S. PEREIRA - G. C. N. GAMA, Instituições de direito civil II - Teoria geral das obrigações, $21^{\mathrm{a}}$ ed., Rio de Janeiro, Forense, 2008, p. 208 e O. GOMES - E. BRITO, Obrigações, $16^{\mathrm{a}}$ ed., Rio de Janeiro, Forense, 2005, pp. 146-47. Para ANTUNES VARELA, por outro lado, a remissão de dívida é justamente "a renúncia do credor ao direito de exigir a prestação, feita com a aquiecência da outra parte", cf. J. M. ANTUNES VARELA, Das obrigações em geral II cit., p. 244. É interessante notar, no que se refere ao CC port., que embora o art. $940^{\circ}$, 2, expressamente afirme que "não há doação na renúncia a direitos", no caso da remissão de débito o art. $863^{\circ}, 2$, expressamente estabelece que "Quando tiver o caráter de liberalidade, a remissão por negócio entre vivos é havida como doação, na conformidade dos artigos $940^{\circ}$ e seguintes".

${ }^{572}$ Cf. F. C. Pontes DE MIRANDA, Tratado de direito privado XLVI cit., pp. 195-96. Para o autor, "não doou A se ordenou, em acordo com B, ao seu motorista que dirigisse o carro de B, e não recebeu pagamento", da mesma forma que "não doa quem ajuda a outrem, ou faz sozinho para outrem, gratuitamente, a cópia a maquina ou presta outro trabalho". 
Assim, não se pode concluir que haja na literatura pátria realmente uma abertura para se admitir as doações de "fazer", ao contrário do direito italiano, em que essa posição tem sido bastante desenvolvida nas últimas décadas. 


\section{Enriquecimento e admissão das doações de fazer no direito italiano}

\section{Enriquecimento nos sentidos econômico e jurídico - o art. 793, 2 do CC italiano}

Ao contrário do CC brasileiro, que exige somente a "transferência" 573 , o art. 769 do CC italiano define a doação como o contrato através do qual uma pessoa enriquece outra, dispondo em seu favor de um direito ou assumindo uma obrigação. A lei italiana, assim, exige expressamente um "enriquecimento" do patrimônio do beneficiário da doação. O dispositivo não menciona o empobrecimento do doador, mas segundo a Exposição de Motivos ao Código, fica subentendido ${ }^{574}$.

A doutrina italiana divide-se em basicamente três posições acerca do requisito: a que enxerga o enriquecimento no sentido econômico, como efetivo incremento patrimonial do donatário (plano da realidade fática), a que o enxerga do ponto de vista jurídico, como equivalente à conferência de um direito real sobre uma coisa (prestação de dar) e a que o considera irrelevante para a caracterização da doação (uma mera descrição dos seus efeitos jurídicos ${ }^{575}$ ).

Entendida no sentido econômico, a menção ao enriquecimento do donatário como elemento da doação causa perplexidade, pois a lei não toma por base para definir o contrato a prestação do doador, mas uma consequência na realidade - um efetivo e real incremento no patrimônio do donatário ${ }^{576}$. A posição consta da própria Exposição de Motivos, que indica que a essência da doação está no efeito econômico, ou seja, no fato de uma parte operar a diminuição no seu patrimônio, proporcionando um incremento no patrimônio de outrem, inspirada pelo puro espírito de liberalidade ${ }^{577}$.

O problema de uma concepção como essa, se levada às últimas consequências, é que só seria possível qualificar o contrato celebrado após a verificação do seu resultado

573 Como visto, porém, a doutrina brasileira entende que um enriquecimento e um empobrecimento são necessários para a configuração da doação, cf. III.1.2.

${ }^{574}$ Cf. D. GRANDI, Relazione del Ministro Guardasigilli al Codice Civile cit., no 372, pp. 7778.

${ }^{575}$ Reproduzimos a distinção feita pela doutrina italiana entre enriquecimento econômico e jurídico, mas já ressaltamos, de antemão, que é algo artificial. Trata-se de planos de análise diferentes. Os defensores da segunda concentram-se na norma em abstrato, i.e., se conceitualmente uma prestação de fazer é apta a produzir enriquecimento. Os defensores da primeira olham para o caso concreto a fim de verificar se houve efetivamente um acréscimo patrimonial.

${ }^{576}$ Cf. A. CATAudella, Successioni e donazioni cit., pp. 5-6 e nt. 16.

78.

${ }^{577}$ Cf. D. GRANDI, Relazione del Ministro Guardasigilli al Codice Civile cit., no 372, pp. 77- 
econômico real. Assim, caso o contrato não produza aquele resultado, seria possível desqualificá-lo como doação. Esse aspecto é bastante discutido na doutrina no que se refere à doação modal em que o ônus absorva totalmente o valor da doação. O art. 793, 2, do CC it. prevê que o donatário é obrigado a adimplir o encargo dentro dos limites de valor da coisa doada ${ }^{578}$.

A regra, em si, é bastante lógica, e guarda analogia com a ideia de que "o herdeiro não responde por encargos superiores às forças da herança", tendo em vista a proximidade com o direito das sucessões (art. 1.792 do CC br). O legislador italiano, com aquele dispositivo, buscou evitar uma espécie de donatio damnosa, por meio da qual o donatário experimentasse prejuízos patrimoniais ao aceitar a doação. Segundo a doutrina, o dispositivo não serve propriamente para assegurar vantagem patrimonial decorrente da doação, mas para evitar que a doação modal se transforme em instrumento de efetivo empobrecimento do donatário ${ }^{579}$.

Em sentido contrário, todavia, o dispositivo dá a entender que, desde que não ultrapasse o valor da doação, o encargo pode absorver totalmente a quantia. Trata-se de uma doação em que o donatário nada recebe - ou melhor, recebe, mas o seu saldo patrimonial efetivo é zero, considerando-se o momento anterior e o posterior à doação. Para tentar compatibilizar a doação modal em que o saldo patrimonial seja zero com o requisito do enriquecimento surgiram diferentes teorias.

Para Mosco, por exemplo, a admissão de doação modal cujo valor do modo fosse igual ou superasse o valor da doação só seria possível se o valor do ônus fosse menor do que o da doação no momento da celebração do contrato, e aumentasse apenas posteriormente. Caso contrário, não se estaria diante de doação, mas de um verdadeiro contrato oneroso ${ }^{580}$.

OPPO e TORRENTE, por outro lado, propunham que o enriquecimento não precisaria se protrair no tempo, sendo suficiente que ocorresse no momento da celebração

\footnotetext{
${ }^{578}$ Art. 793 , 2. Il donatario è tenuto all'adempimento dell'onere entro i limiti di valore della cosa donata.

${ }^{579}$ Cf. A. Cataudella, Successioni e donazioni cit., pp. 9-10 e G. ConTE, Il contratto di donazione tra liberalità e gratuità cit., p. 35.

${ }^{580}$ Cf. L. MOSCO, Onerosità e gratuità degli atti giuridici con particolare riguardo ai contratti, Milano, Vallardi, 1942, p. 352-55.
} 
do contrato. Assim, ainda que o posterior cumprimento do ônus anulasse o enriquecimento que ocorrera, tal incremento patrimonial inicial seria suficiente para manter a caracterização do ato como doação ${ }^{581}$.

CATAUDELla critica ambas as teorias por instituir limitações que não constam do texto da lei e por não conseguir contornar o fato de que, se a lei exige um objetivo enriquecimento pelo donatário, tal enriquecimento efetivamente acaba não ocorrendo ${ }^{582}$. Com relação à segunda teoria, além disso, afirma BIANCA que ao se isolar o enriquecimento inicialmente experimentado do empobrecimento decorrente do ônus, cinde-se arbitrariamente um regulamento contratual unitário, o que é inaceitável ${ }^{583}$.

Uma solução aventada para o problema é se entender que o enriquecimento existe conforme a avaliação subjetiva e o acordo das partes contratantes, independentemente de um enriquecimento efetivo ${ }^{584}$. Move-se, assim, o enriquecimento do plano dos fatos para o plano das ideias, do acordo. A lógica desse raciocínio reside no fato de que a equivalência objetiva entre as prestações, isto é, a circunstância de que o valor econômico de uma prestação corresponde ao valor da outra não é requisito em geral dos contratos a título oneroso ${ }^{585}$.

Para fazer um paralelo com o direito brasileiro, a possibilidade de anulação do negócio jurídico por lesão, por exemplo, está sujeita a requisitos bastante específicos deve haver "premente necessidade" ou "inexperiência", e uma prestação "manifestamente desproporcional" ao valor da outra ${ }^{586}$. Se uma discrepância entre o valor da prestação e o da contraprestação, em regra, não serve para alterar a qualificação dos contratos onerosos, o mesmo raciocínio deve valer para a doação. Assim, o fato de o encargo ter valor igual ao

${ }^{581}$ Cf. G. OpPO, Adempimento e liberalità cit., p. 66, nt. 1 da p. 65 e A. TORRENTE, La donazione, in A. CICU - F. MESSINEO, Trattato di diritto civile e commerciale XXII, Milano, Giuffrè, 1956, p. 6.

${ }^{582}$ Cf. A. Cataudella, Successioni e donazioni cit., pp. 7-8.

${ }^{583}$ Cf. C. M. BIANCA, Diritto civile III cit., p. 427.

${ }^{584}$ Cf. U. CARnevali, La donazione modale, Milano, Giuffrè, 1969, p. 138.

${ }^{585}$ Cf. C. M. BIANCA, Diritto civile III cit., p. 490.

586 Art. 157. Ocorre a lesão quando uma pessoa, sob premente necessidade, ou por inexperiência, se obriga a prestação manifestamente desproporcional ao valor da prestação oposta. 
do bem doado não incidiria sobre a qualificação jurídica da doação, e a ausência de um objetivo enriquecimento não seria suficiente para descaracterizá-la ${ }^{587}$.

Uma crítica a essa visão, entretanto, está no fato de que, por ser "subjetiva", pode levar a uma confusão com o animus donandi ${ }^{588}$, a depender da concepção que se adote acerca deste último. Para escapar às críticas, propôs-se entender o enriquecimento não do ponto de vista econômico, mas jurídico. O que na verdade deve ser analisado é o meio jurídico através do qual esse resultado é perseguido, como a transferência de um direito real, a assunção de uma obrigação etc. Uma vez que não são coisas que o doador transfere ao donatário, mas direitos sobre $\operatorname{coisas}^{589}$, o fato de tal meio jurídico normalmente acarretar um aumento do patrimônio líquido do donatário ${ }^{590}$ não seria essencial à doação ${ }^{591}$. Nesse entendimento, ganha importância a distinção entre as prestações de dar e de fazer (e não fazer), isto é, pergunta-se se a ideia de enriquecimento jurídico abarca somente as primeiras ou também as segundas. Esse ponto será melhor explorado no tópico seguinte (III.2.2.).

Uma terceira posição retira a relevância do enriquecimento como elemento caracterizador da doação, e o considera mera "descrição" dos efeitos jurídicos que

${ }^{587}$ Cf. A CATAUdella, Successioni e donazioni cit., pp. 9-10. Em sentido semelhante, BIONDI afirmava que é irrelevante uma correlação econômica ou aritmética entre a perda do doador e o ganho do donatário, pois além de não ser mencionada pelo art. 769, a doação com encargo não deixa de ser doação, cf. B. BIONDI, Le donazioni cit., pp. 92-93

${ }^{588}$ Cf. G. CONTE, Il contratto di donazione tra liberalità e gratuità cit., p. 36.

${ }^{589}$ Podem-se distinguir objetos de direito de primeira ordem de objetos de segunda ordem. Os primeiros são as coisas materiais ou imateriais sobre as quais é possível um direito de domínio ou utilização frente a terceiros; os segundos são direitos subjetivos ou relações jurídicas, que podem ser objetos de negócios de disposição, cf. K. LARENZ, Allgeneiner Teil des deutschen Bürgerlichen Rechts, $3^{\mathrm{a}}$ ed., München, Beck, 1975, trad. esp. Miguel Izquierdo y Macías-Picavea, Derecho civil - Parte general, Madrid, Edersa, 1978, pp. 369-70 e 396.

${ }^{590}$ É preciso tomar cuidado com o sentido da palavra "patrimônio" usado no texto. Se se entende o patrimônio, quer como patrimônio global - "o conjunto de relações jurídicas ativas e passivas (direitos e obrigações) avaliáveis em dinheiro de que uma pessoa é titular" -, quer como patrimônio bruto somente as relações jurídicas ativas - uma transferência de direitos sempre acarretará um incremento nesse patrimônio. Quando se fala que para a corrente defensora de um sentido "jurídico" de enriquecimento não é essencial à doação um aumento de patrimônio, o sentido desta palavra é o de patrimônio líquido ou saldo patrimonial, uma acepção que "tem um valor puramente econômico", pois significa o ativo menos o passivo. Para os três diferentes conceitos de patrimônio, cf. C. A. Mota PINTO - A. Pinto Monteiro - P. MotA PINTO, Teoria geral do direito civil, $4^{\mathrm{a}}$ ed., Coimbra, Coimbra, 2005, pp. 344-46.

${ }^{591}$ Cf. A. CHECCHINI, L'interesse a donare cit., p. 309. Para Morozzo DELla RocCA, haverá doação modal e não um negócio oneroso todas as vezes em que, no momento da celebração do negócio, a prestação exigida da outra parte não contradiga a natureza "donativa" do acordo, cf. P. MorOzZO DELLA RoCCA, Gratuità, liberalità e solidarietà cit., p. 29. 
normalmente ocorrem ${ }^{592}$. O problema dessa posição é que se afasta de um dado legislativo bastante claro, isto é, o art. 769 efetivamente parece prever o enriquecimento como elemento essencial da doação ${ }^{593}$.

\section{Prestações de fazer - enriquecimento e empobrecimento}

A redação do art. 769 consagrou no direito italiano as doações in obligando, por meio das quais o doador se obriga a uma prestação em favor do donatário. $\mathrm{O}$ dispositivo não estabelece limitação em relação à prestação, dando a entender, em princípio, que o conteúdo do contrato de doação possa consistir na assunção de todo tipo de obrigação ${ }^{594}$. Ocorre, porém, que o mesmo dispositivo exige o "enriquecimento" do donatário. Pergunta-se se esse enriquecimento limita a doação à assunção de uma obrigação de dar, ou se pode abranger também as prestações de fazer.

Para parte considerável da doutrina só seria possível a assunção de obrigações de dar, pois as prestações de fazer e não fazer não importam enriquecimento do beneficiário $^{595}$ ou empobrecimento do prestador. Além disso, o fato de a doação ter por objeto prestações de dar, seria, para uma corrente, justamente o que a distingue dos demais

${ }^{592}$ BISCONTINI sintetiza bem a posição da doutrina italiana acerca do enriquecimento. Pode ser entendido em um sentido econômico ou jurídico. No sentido jurídico, seria a atribuição de um direito real de gozo ou a assunção de uma obrigação de dar. O autor conclui que em nenhum desses sentidos pode ser visto no enriquecimento aquele elemento característico da "minima unità effetuale", seja em razão do art. 793, 2, e no fato de também se vislumbrar "enriquecimento" em outros contratos gratuitos (sentido econômico), seja em razão da ausência de limitação do art. 769 quanto às doações de fazer, cf G. BISCONTINI, Onerosità, corrispettività e qualificazione dei contratti cit. pp. 151-54 e 157-60.

${ }^{593}$ Para CARNEVALI, entender o enriquecimento como uma "descrição", ou como um resultado "normal, mas não essencial" contrasta com o caráter essencial dado a esse elemento pelo legislador. A solução seria entender o enriquecimento não como um efeito jurídico, mas como fattispecie, isto é, como o "oggetto dell'intento del donante, condiviso dal donatario", cf. U. CARNEVALI, Le donazioni, in RESCIGNO, Pietro (org.), Trattato di diritto privato VI - Successioni II, Torino, UTET, 1997, pp. 496-98. Ainda, cf. U. CARneval, Donazione (diritto civile), in Enc. giur. Treccani 12 (1989), p. 2. ENGISCH aponta que se pode duvidar, "num caso concreto, sobre o que pertence à 'hipótese legal' e o que faz parte da 'consequência jurídica'. A solução aventada é que pertence "à hipótese legal tudo aquilo que se refere à situação a que vai conexionado o dever-ser (Sollen), e à consequência jurídica tudo aquilo que determina o conteúdo desde dever-ser", cf. K. ENGISCH, Introdução ao pensamento jurídico cit., p. 55.

${ }^{594} \mathrm{Cf}$. L. BozZI, Alla ricerca del contratto gratuito atipico cit., pp. 222-23.

595 OPPO sintetiza bem essa posição. Segundo o jurista, a diferença entre as liberalidades (doação + liberalidades diversas) e os demais atos gratuitos se daria em função da natureza da vantagem que se busca procurar à outra parte. No caso das liberalidades, consiste no enriquecimento do donatário; no caso dos outros contratos gratuitos, como mútuo, comodato e mandato, nas prestações próprias de cada negócio, cf. G. OPPO, Adempimento e liberalità cit., pp. 288-89. 
contratos gratuitos ${ }^{596}$. A distinção entre prestações de dar e fazer, que não foi expressamente adotada como critério de classificação das obrigações no $\mathrm{CC}$ italiano ${ }^{597}$, ressurgiria com toda importância em tema de doação.

Já não tão recentemente, todavia, e diante do dado positivo do art. 769, vem sendo criticada a posição de que as prestações de fazer não geram enriquecimento ou empobrecimento. BIONDI já afirmava que não há uma diferença tão substancial entre a doação e os demais contratos gratuitos. A razão pela qual estes não poderiam ser considerados doação seria o fato de que nenhum negócio típico pode ser, ao mesmo tempo, um outro negócio típico. Não é possível que um mesmo contrato seja ao mesmo tempo doação e mútuo, comodato ou mandato ${ }^{598}$.

O problema permanece, porém, para os contratos gratuitos atípicos. As vantagens que aufere o beneficiário também poderiam ser apreciáveis economicamente quanto à utilidade do serviço, e o prestador dos serviços também sofre um mancato guadagno ou omissio adquirendi com o não recebimento da contraprestação. Ao prestar um serviço gratuito, aliás, o prestador não seria apenas privado da contraprestação que poderia ter tido - ou, colocando a questão de outra forma, do tempo da atividade que poderia ser usado para executar uma atividade que lhe renderia uma contraprestação. Ele certamente teria despesas, por menores que sejam, para dar cumprimento à prestação e para repor as energias físicas e psíquicas despendidas com a execução ${ }^{599}$.

Segundo GiAnOLA, os defensores da inidoneidade das prestações consistentes em serviços em produzir enriquecimento e empobrecimento têm em vista uma prestação realizada em um momento vago, fora do horário de trabalho do prestador, e que não acarretaria diminuição patrimonial para ele ${ }^{600}$. Desconsideram, todavia, o fato de que pode ter havido uma renúncia à contraprestação, além do que a fadiga, o cuidado e a atenção

${ }^{596}$ Cf. II.4.2.

${ }^{597}$ A classificação não consta do Livro IV, Título I, Capítulo VII, que trata "Di alcune specie di obbligazioni", ao contrário da orientação do Code civil (mais de um século mais antigo) que disciplina as obrigações "de donner" a partir do art. 1.136 e as "de faire ou de ne pas faire", a partir do art. 1.145.

${ }^{598}$ Cf. B. BIONDI, Le donazioni cit., pp. 92-93.

${ }^{599}$ Cf. F. M. D’ETTORE, Intento di liberalità e attribuzione patrimoniale cit., pp. 4-7 e 9-12.

${ }^{600}$ COSTANTINO refere-se a uma frase de Sêneca: "Nessuno che abbia fatto perdere del tempo a qualcuno si è mai sentito debitore di qualcosa. Eppure questo è il bene che è più difficile da restituire", cf., M. COSTANTINO, La gratuità, la qualificazione dei beni e l'accesso alla proprietà altrui, in A. GALASSO - S. MAZZARESE (org.), Il principio di gratuità cit., p. 482. 
despendidos pelo prestador dos serviços podem sim ser avaliados de maneira objetiva e abstrata, como ocorre no caso do ressarcimento de um dano. Por exemplo, se em razão de um acidente automobilístico ou do furto do bilhete, alguém é privado de assistir a um espetáculo, não se duvida que possa obter indenização, embora o ato de apreciar $\mathrm{o}$ espetáculo não aumente - e nem a sua privação diminua - o patrimônio do lesado ${ }^{601}$.

Outro argumento favorável a uma acepção ampla de enriquecimento e empobrecimento está no fato de que, no direito italiano, os intérpretes admitem, pacificamente, que a ação de enriquecimento injustificado ${ }^{602}$ possa ser utilizada nos casos em que se está diante de prestações de fazer ${ }^{603}$. BIANCA, por exemplo, afirma que o enriquecimento é toda vantagem suscetível de apreciação econômica. Pode consistir, além de um incremento patrimonial, em evitar uma perda patrimonial ou utilizar temporariamente um bem ou de um serviço. Por outro lado, o empobrecimento ocorre, além da perda de um bem, no caso do fornecimento de um serviço ${ }^{604}$.

Isso demonstra, para GIANOLA, a coexistência no mundo do direito de duas noções diversas de enriquecimento e empobrecimento. O intérprete não seria coerente, pois, de um lado, admite que uma prestação de serviços acarreta uma vantagem para o beneficiário e um prejuízo para o prestador tais que justificam a aplicação das regras do enriquecimento injustificado; de outro lado, entende que esses mesmos fatos são insuficientes para configurar o enriquecimento e o empobrecimento necessários para que haja doação ${ }^{605}$. 2002, pp. 51-52.

${ }^{601}$ Cf. A. Gianola, Atto gratuito, atto liberale - Ai limiti della donazione, Milano, Giuffrè,

${ }^{602} \mathrm{O}$ "arricchimento senza causa" é disciplinado nos arts. 2.041 e 2.042 do CC it., O art. $2.041,1$, que trata da "azione generale di arricchimento", assim dispõe:

Art. 2.041. Azione generale di arricchimento. 1. Chi, senza una giusta causa, si è arricchito a danno di un'altra persona è tenuto, nei limiti dell'arricchimento, a indennizzare quest'ultima della correlativa diminuzione patrimoniale.

O outro dispositivo, por sua vez, trata do caráter subsidiário da ação de enriquecimento:

Art. 2.042. Carattere sussidiario dell'azione. L'azione di arricchimento non è proponibile quando il danneggiato può esercitare un'altra azione per farsi indennizzare del pregiudizio subito.

${ }^{603}$ Cf. A. GiAnOla, Atto gratuito, atto liberale cit., p. 52 e A. ALBANESE, Prestazione gratuita, spirito di liberalità e vantaggi indesiderati (il proplema degli scambi imposti), in Contratto e impresa 23 (2007), p. 483.

${ }^{604}$ Cf. C. M. BianCA, Diritto civile V-La responsabilità, Milano, Giuffrè, 1994, pp. 813-14 e 818.

\footnotetext{
${ }^{605}$ Cf. A. Gianola, Atto gratuito, atto liberale cit., pp. 51-53.
} 
Parece, por alguma razão, que a doutrina mais tradicional em matéria de doação faz um esforço enorme para limitar a interpretação dada ao "enriquecimento" mencionado no art. 769, a fim de excluir do âmbito da doação a assunção gratuita de obrigações de fazer. Possíveis razões para isso serão vistas no tópico seguinte (III.2.3).

\section{Justificativa e consequências da admissão de doações de fazer}

Segundo FERRI, historicamente, tanto no Code civil quanto no CC de 1865, testamento, doação e contratos, mais do que atos de autonomia privada, eram vistos como instrumentos técnicos para a circulação das riquezas proprietárias. Tanto é assim que sua disciplina era inserida no Livro III de ambos os códigos, denominados, respectivamente, "Des différentes manières dont on acquiert la propriété" e "Dei modi di acquistare e di trasmettere la proprietà e gli altri diritti sulle cose".

Eram códigos elaborados por e para uma sociedade de comerciantes e proprietários imobiliários - "uma sociedade do ter, que concentrava na propriedade a expressão eminente do poder econômico e da riqueza". Nesse sentido, não podia ser diferente a concepção da doação a partir de uma "chiave proprietaria", de acordo com a qual o empobrecimento e o enriquecimento eram respectivamente vistos como a saída da propriedade de um bem de um patrimônio e sua entrada em outro ${ }^{606}$.

De acordo com FERRI, essa concepção, que fazia sentido em uma sociedade do ter - na qual a riqueza e o patrimônio mercantil e familiar se fundavam na propriedade -, tornou-se em certa medida anacrônica em uma sociedade que se transformou em uma sociedade do fazer, que dá importância à capacidade e qualidade de quem faz, empreende e trabalha. O Código de 1942, aliás, já teria refletido esse novo modelo de sociedade através da unificação das disciplinas do direito civil e comercial e da centralidade dada ao trabalho e à empresa ${ }^{607}$. Assim, não haveria justificativa, na sociedade atual, para limitar a doação às prestações de dar ${ }^{608}$.

${ }^{606}$ Cf. G. B. FERRI, Dall'intento liberale al cosidetto impegno etico e superetico cit., pp. 45-46.

${ }^{607}$ Cf. G. B. FerRI, Dall'intento liberale al cosidetto impegno etico e superetico cit., pp. 45-46. Em sentido contrário, PENTEADO aponta que "a progressiva desmaterialização a que está submetida a geração contemporânea pode levar a crer que se está na era apenas e tão somente dos contratos e obrigações, da empresa e do feixe de relações obrigacionais interligadas, no mundo virtual". Porém, "o Direito das Coisas, 
Enquadrada nesses termos, a posição que assume parte da doutrina italiana parece, no mínimo, paradoxal. Ao mesmo tempo em que parece querer favorecer a prática de doações, ao apontar como algo "moderno" a inclusão das prestações de fazer em seu âmbito, parece esquecer-se que a doação no direito italiano é sujeita a uma disciplina jurídica rigorosa, e inclusive deve se revestir de forma solene ${ }^{609}$.

Ao buscar sair do suposto anacronismo da "società del dare", a doutrina acabaria caindo no anacronismo da forma solene, que, para alguns, é uma trava à livre circulação de riquezas na sociedade moderna e alvo de uma tendência internacional de mitigação ${ }^{610}$. A aparente contradição é semelhante àquela em que incorre BIONDI ao afirmar que a ampliação, pelo CC de 1942, do âmbito da doação para além da doação translativa do direito de propriedade e constitutiva de direitos reais, admitindo também a obrigatória e a liberatória, seria sinal de que teria havido um favorecimento da doação com relação à lei anterior ${ }^{611}$.

Não parece ser o enquadramento correto da questão. A única maneira de se entender que a inclusão das prestações de fazer no âmbito da doação favorece a sua prática é se concluir que, caso contrário, a prática dessas prestações é proibida. Não parece ser o

longe de ser um objeto de estudo ultrapassado e arcaico, próprio de textos desatualizados e empoeirados, é perenemente atual" e isso se dá porque o ser humano "necessita de um mínimo de concretude corpórea, de "um espaço vital, de estabilidade, de ficar, de permanecer", cf. L. C. PEnTEADO, Direito das coisas cit., p. 38.

${ }^{608}$ Cf. F. M. D’ETTORE, Intento di liberalità e attribuzione patrimoniale cit., pp. 4-6, 9-12 e 17. D'ETTORE afirma que a doutrina mais tradicional ignora as "energias psico-físicas do homem", por entender não serem dotadas de "espessura patrimonial" e acabava sustentando uma concepção de trabalho humano e das forças produtivas fisicas e intelectuais anacrônica e improponível nos dias de hoje. Ignora, segundo o autor, a extraordinária importância das atividades pessoais e de trabalho não material e da disposição a título gratuito das forças físicas e intelectuais do homem. Assim, seria injustificado excluir da disciplina da doação prestações de serviços que geram prejuízo econômico para o prestador, um prejuízo não menos sério e relevante, em termos de valor, do que o experimentado com a transferência do direito de propriedade ou constituição de um direito real em favor de outrem.

${ }^{609}$ LENZI aponta que o debate sobre a admissibilidade da doação de fazer tem como pano de fundo as razões práticas que procuram subtrair tais negócios dos rigorosos requisitos formais previstos para a doação, cf. R. LenZI, Donazione obbligatoria cit., p. 1617. Também, cf. L. PellegrinI, La donazione costitutiva di obbligazione cit., p. 12.

${ }^{610} \mathrm{Cf}$. G. CONTE, Il contratto di donazione tra liberalità e gratuità cit., pp. 41-42. Em sentido contrário, LENZI, apoiado em ampla bibliografia, fala em um neoformalismo, isto é, um movimento de retorno à valorização da forma com finalidades protetivas, principalmente na legislação especial. Para o autor, é justamente a tendência dos autores que buscam excluir as prestações de fazer dos requisitos formais que iria contra esse movimento de revalorização da forma. Afirma, por outro lado, que a posição é compreensível, ante o favorecimento da ideia de solidariedade social e pelo fato de que a forma solene acaba sendo um obstáculo à rápida circulação jurídica, cf. R. LENZI, Donazione obbligatoria cit., pp. 1617-19 e nt. 8 .

${ }^{611}$ Cf. B. BIONDI, Le donazioni cit., pp. 12-15. 
caso, para CONTE, na medida em que isso contrariaria valores constitucionais que favorecem o altruísmo e implicaria uma visão insuportavelmente restrita de liberdade e autonomia negocial $^{612}$.

Haveria, ao contrário, fortes argumentos dogmáticos para limitar a doação às prestações de dar. Há quem afirme que prestações de fazer não representariam um perigo tão grande para o doador, seus herdeiros e credores quanto a transferência de um direito real a ponto de se justificar a ampliação do objeto da doação ${ }^{613}$.

Além disso, haveria um "valor sistêmico" no fato de que o CC subtraiu à disciplina da doação os principais esquemas de serviços gratuitos e com relação a esses contratos não há uma postura rígida ou de suspeição. O sistema de circulação de direitos adotado pelo CC de 1942 possuiria uma articulação interna bastante precisa, que não deve ser diminuída. Ao contrário, a própria existência de outros contratos gratuitos típicos indica que a vontade do legislador foi a de não ampliar a doação para além de limites bastante específicos. Há, pois, coerência interna ${ }^{614}$.

Há um outro ponto, porém, que merece ser desenvolvido. Uma possível razão para se incluir as prestações gratuitas de fazer entre as doações submetidas à forma solene, que é garantir a vinculação do prestador. Uma das funções das regras jurídicas é determinar que condutas são obrigatórias, proibidas ou permitidas ${ }^{615}$. Dizer que as prestações de fazer gratuitas são permitidas não implica dizer, automaticamente, que podem se tornar obrigatórias para o prestador.

Não é pacífico que se possa exigir o cumprimento de um contrato pelo qual um sujeito se obriga a prestar gratuitamente um serviço ${ }^{616}$ e podem surgir problemas

${ }^{612}$ Cf. G. CONTE, Il contratto di donazione tra liberalità e gratuità cit., pp. 41-42 e III.4.1.

${ }^{613} \mathrm{Cf}$. F. M. D'ETTORE, Intento di liberalità e attribuzione patrimoniale cit., pp. 13-16.

${ }^{614} \mathrm{Cf}$. G. CONTE, Il contratto di donazione tra liberalità e gratuità cit., p. 44. No mesmo sentido, para PICCININI, a existência de contratos gratuitos típicos não sujeitos à forma solene no CC italiano poderia ser entendida como prova de que a doação se limita às prestações de dare, cf. S. PICCININI, Profili della donazione dal codice 1865 ad oggi cit., p. 194.

${ }^{615}$ Cf. J. R. L. LoPES, Regla y compás cit., p. 52: "Dudas, indagaciones y cuestiones jurídicas pueden resumirse en saber si alguna cosa o, mejor dicho, alguna acción o algún estado de cosas está prohibido, está permitido o es obligatorio, de acuerdo con el derecho".

${ }^{616}$ A discussão é semelhante à que se coloca para o contrato preliminar de doação, cf. I.6. Para PELLEGRINI, o contrato que tenha por objeto o adimplemento de uma prestação gratuita de fazer pode sim ter o seu cumprimento exigido, desde que atenda aos interesses merecedores de tutela segundo o ordenamento jurídico mencionado pelo art. 1.322, 2. Se tal contrato for destinado a interesses não econômicos, será 
complexos em razão de prestações de fazer gratuitas não cumpridas, cumpridas defeituosamente ou parcialmente, em razão de eventuais prejuízos e expectativas que possam gerar no beneficiário ${ }^{617}$. Se a obrigação de fazer integra um contrato de doação, o problema se resolve, pois estando tipificada como um dos "interessi meritevole di tutela secondo l'ordinamento giuridico", ela vincula o prestador a cumprir o serviço prometido $^{618}$.

doação, e serão aplicadas as regras desta, inclusive quanto à forma. Caso contrário, se estiverem presentes interesses patrimoniais, não se aplicarão as regras de forma, mas o prestador será, em ambos os casos, obrigado a prestar, cf. L. PELLEGRINI, La donazione costitutiva di obbligazione cit., p. 205.

${ }^{617}$ Há quem entenda resolver a questão no plano da responsabilidade aquiliana, e surge o problema acerca dos critérios para essa responsabilização, de maneira a não desestimular a prática de atos de altruísmo (essa questão do estímulo ou desestímulo à prática do ato, de uma maneira geral, é discutida sob a perspectiva do Law and Economics em interessante artigo de R. POSNER, Gratuitous Promises in Economics and Law, in The Journal of Legal Studies 6 [1977], pp. 411-426). Pode-se questionar a adoção dos "parâmetros subjetivos" do dolo e da culpa, previstos como regra geral:

Art. 2.043. Risarcimento per fatto illecito. Qualunque fatto doloso o colposo, che cagiona ad altri un danno ingiusto, obbliga colui che ha commesso il fatto a risarcire il danno.

Uma possível solução consiste em adotar o critério do dolo ou culpa grave mencionado pelo art. 414 do "Codice della Navigazione" para o "trasporto amichevole":

Art. 414. Responsabilità del vettore nel trasporto amichevole. Chi assume il trasporto di persone o di bagagli a titolo amichevole è responsabile solo quando il danneggiato provi che il danno dipende da dolo o colpa grave del vettore o dei suoi dipendenti e preposti.

Sobre essas questões, cf. L. BozZI, Alla ricerca del contratto gratuito atipico cit., p. 215.

${ }^{618}$ Cf. A. GiAnOlA, Atto gratuito, atto liberale cit., pp. 70-71. Segundo uma posição que será vista em III.4.1, seria justamente a forma solene o que garante a juridicidade (e vinculatividade) ao acordo. 


\section{Elemento subjetivo - animus donandi como traço caracterizador da doação}

\section{Sentido subjetivo e críticas a essa concepção}

Na França, pelo menos desde DoMAT, o animus donandi guarda relação com a ideia de causa impulsiva ${ }^{619}$. Em uma referência trazida por GHESTIN, aquele jurista afirmava que a prestação do doador tinha fundamento em algum motivo razoável ou justo, como um serviço feito, em algum mérito do donatário, ou no puro prazer de beneficiar ${ }^{620}$. A referência ao motivo razoável ou justo diz respeito aos subtipos da doação, que constituiriam exceção ao princípio da irrelevância dos motivos ${ }^{621}$.

O encargo, por exemplo, pode consistir em motivo determinante da doação, conforme explicitamente dispõe o art. 137. São exemplos dessas doações motivadas, no CC brasileiro, a doação "feita em contemplação do merecimento do donatário", a doação "remuneratória", doação "gravada" (referidas no art. 540) e a "doação feita em contemplação de casamento futuro com certa e determinada pessoa" (art. 546). O CC italiano, igualmente, também prevê diversas modalidades de doação, tais como a remuneratória (art. 770) e a doação modal (art. 793) ${ }^{622}$.

A doação pura, por outro lado, é a que, segundo DOMAT, se caracterizava pelo "puro prazer de beneficiar", que ocupa o lugar da causa ("tient lieu de cause de la part de celui qui reçoit et ne donne rien" ${ }^{623}$. Note-se o cuidado desse jurista ao não afirmar categoricamente que é a causa, o que demonstra que o autor reconhece uma possível inadequação dos conceitos de direito privado ligados ao mercado para lidar com a doação.

Esse "puro prazer de beneficiar" é o animus donandi concebido em um sentido subjetivo, como um sentimento de pura beneficência ou um estado de espírito altruísta e III cit., pp. 449-50.

${ }^{619}$ Cf. A. SÉRIAUX, Les successions - Les libéralités cit., p. 128 e C. M. BIANCA, Diritto civile

${ }^{620}$ Cf. J. GHESTIN, Cause de l'engagement et validité du contrat cit., pp. 19-20 e 860.

${ }^{621}$ Cf. A. JunQUEIRA DE AZEVEDO, Negócio jurídico e declaração negocial cit., pp. 213-14, M. C. Bodin DE MORAES, Notas sobre a promessa de doação cit., pp. 8-9 e F. C. PONTES DE MIRANDA, Tratado de direito privado XLVI cit., p. 229.

${ }^{622}$ Cf. A. CATAudella, Successioni e donazioni cit., p. 47. Essas modalidades de doação, segundo o autor, seriam caracterizadas por apresentar traços não presentes e que se acrescem à "fattispecie" típica, mas que não são suficientes para gerar uma incompatibilidade com o tipo - apenas delimitam um âmbito mais restrito ao qual se aplicará uma particular disciplina jurídica. As diversas modalidades de doação podem ser percebidas a partir do próprio Título $\mathrm{V}$ do Livro II, no qual se encontra a disciplina da doação, denominado "Delle donazioni", no plural.

${ }^{623}$ Cf. J. GHESTIN, Cause de l'engagement et validité du contrat cit., pp. 19-20 e 860. 
inteiramente desinteressado. Para que fique caracterizado, deve-se indagar acerca dos motivos internos ou psicológicos do doador. Se ficar evidenciado um interesse pessoal, material ou moral, deve-se excluir a intenção liberal e, portanto, reconhecer não se estar diante de uma doação ${ }^{624}$.

Embora a doutrina francesa reconheça uma concepção mais objetiva, GIANOLA aponta ser surpreendente que os tribunais daquele país adotem, até hoje, uma concepção subjetiva do animus donandi. A razão disso é, da mesma forma que o reconhecimento das doações manuais, simuladas e indiretas, conferir validade a doações praticadas com defeito de forma. Para favorecer atribuições a entidades sem fim lucrativo pautadas pelo interesse coletivo e, assim, exclui-las dos rígidos requisitos exigidos para o contrato de doação, os tribunais tendem a excluir da noção desta os atos destinados a satisfazer interesses morais do disponente, os reputando incompatíveis com o intento liberal ${ }^{625}$.

Segundo DAWSON, os tribunais "testam" - através de um "trace-of-selfishness test" - os motivos do doador para decidir se o negócio é doação. Relativamente cedo, na França, surgiu a necessidade de se enfrentar o problema de atribuições gratuitas feitas a igrejas ou em outras situações consideradas dignas de tutela nas quais houve o questionamento da validade do ato em razão da ausência de notarização. Para "salvar" tais negócios da invalidade, os tribunais passaram a insistir na generosidade e no altruísmo necessários, e a procurar nos casos concretos alguma "impureza" nos motivos que fizesse com que tais transações não se encaixassem em seu conceito ${ }^{626}$.

DAWSON ironiza o fato de que os tribunais franceses têm tanto respeito e estima pela desinteressada generosidade que raramente reconhecem a sua existência, tornando a exigência da forma solene, na prática, bastante flexível. O fato é que uma

${ }^{624}$ Cf. S. LAMBERT, L'intention libérale dans les donations, Aix-en-Provence, PUAM, 2006, pp. 218-19 e P. RAYNAUD, Les successions et les libéralités cit., p. 327. Segundo Malaurie, a intenção liberal ou animus donandi é identificada através de uma análise necessariamente psicológica, cf. $\mathrm{Ph}$. MALAURIE, Les successions - Les libéralités cit., pp. 177-80.

${ }^{625} \mathrm{Cf}$. A. GIANOLA, Interesse morale e spirito di liberalità nella giurisprudenza francese, in Riv. dir. civ. 49 (2003), pp. 71-72 e 86.

${ }^{626}$ Cf. J. P. DAwson, Gifts and Promises cit., pp. 120-21. 
concepção tão pura e desinteressada leva todo interesse do doador no ato a descaracterizálo, reduzindo sensivelmente o número de hipóteses caracterizadas como doação ${ }^{627}$.

A grande desvantagem está na dificuldade de se fazer uma análise dos motivos psicológicos que levaram o doador a praticar o ato. BETTI, em sua crítica ao "dogma da vontade", afirmava que "il diritto non concede la propria sanzione al mero arbitrio, al capriccio individuale, al motivo transeunte (motivo, che, anche quando non sia frivolo, ma plausibile, rimane irrilevante)”. Da mesma forma que nos negócios onerosos, nos negócios a título gratuito não se poderia confundir o interesse objetivo e típico (causa abstrata) de enriquecer outra pessoa sem contrapartida com os motivos individuais que, em cada caso, determinam a realização da liberalidade. Ainda que no caso concreto haja um nexo psicológico entre os motivos e a realização do negócio, esses são imponderáveis, “essenzialmente soggettivi” e, assim, irrelevantes para o direito ${ }^{628}$.

Por essa razão, na Itália, desde cedo se passou a reconhecer que não se pode identificar o intento liberal ou espírito de liberalidade com o puro altruísmo, pois se acaba negando a qualidade de doação a atribuições realizadas por interesses menos "nobres"629. MANZINI cita como exemplo aquelas realizadas por vaidade, para humilhar o donatário ou conquistar-lhe a confiança e gratidão em virtude de objetivos egoístas ${ }^{630}$. Uma identificação concreta de elementos tão íntimos é muito difícil de ser feita, pois dificilmente emerge do comportamento das partes ${ }^{631}$.

Em uma passagem muito citada, afirmava GoRLA que, na realidade da vida, não existe doação que não seja determinada por um interesse diverso do puro espírito de liberalidade. Este é algo muito abstrato e talvez tão raro quanto o imperativo categórico de Kant. Normalmente se doa ou se pratica outro ato gratuito com os mais variados interesses

${ }^{627}$ Cf. S. LAMBERT, L'intention libérale dans les donations, Aix-en-Provence, PUAM, 2006, pp. 218-19, Ph. MALAURIE, Les successions. Les libéralités cit., p. 145 e P. RAYNAUD, Les successions et les libéralités cit., p. 327.

${ }^{628}$ Cf. E. BETTI, Teoria generale del negozio giuridico cit., pp. 57 e 176, principalmente.

${ }^{629}$ A concepção objetiva desenvolvida na França vai na mesma linha. CAPITANT, por exemplo, afirmava que o amor, a amizade, o reconhecimento, a caridade, a vaidade ou até a corrupção são externos ao ato de vontade, e, portanto, indiferentes, cf. H. CAPITANT, De la cause des obligations cit., pp. 81-82.

${ }^{630}$ RoDOTÀ lembra que a doação pode ser muitas vezes instrumento de domínio, cf. S. RoDOtÀ, Gratuità e solidarietà tra impianti codicistici e ordinamenti costituzionali, in A. GALASSO - S. MAZZARESE (org.), Il principio di gratuità cit., p. 101.

${ }^{631}$ Cf. C. MANZINI, "Spirito di liberalità" e controllo giudiziario sull'esistenza della causa donandi, in Contratto e impresa 2 (1985), p. 413. 
possíveis - interesses afetivos, familiares, científicos, esportivos, vaidade, ambição, expectativa de prestígio etc. -, constituindo o puro intento de beneficiar, mais do que regra, a exceção $^{632}$.

GIANOLA afirmando que a realização de prestações sem contrapartida nem sempre é determinada pela generosidade, procurou classificar os fins perseguidos por aqueles que as praticam. Entre os dois extremos do contrato bilateral sinalagmático com prestações correspondentes economicamente apreciáveis e da doação determinada pelo puro altruísmo existiriam várias hipóteses intermediárias, nas quais a ideia econômica de troca vai progressivamente arrefecendo ${ }^{633}$.

O autor identifica, nesse âmbito, seis hipóteses diferentes de finalidades que podem inspirar a prática do ato:

(i) obtenção de vantagem econômica futura que não consiste em uma contraprestação, como no caso de brindes entregues a título de propaganda, mediante a qual o praticante tem a expectativa de adquirir novos clientes;

(ii) obtenção de bens fora do comércio, como simpatia, afeto, estima, benevolência, proteção ou até o favor eleitoral;

(iii) retribuição ou manifestação de reconhecimento por uma vantagem gratuitamente recebida no passado, como no caso das liberalidades remuneratórias;

(iv) adequação a uma convenção social, como no caso das liberalidades de uso;

(v) realização de ideais laicos ou religiosos consistentes, por exemplo, no auxílio a pessoas em situação de necessidade, como no caso do voluntariado; e

(vi) a concretização da pura generosidade, determinada pelo desejo de fazer bem ao próximo, por afeto, compaixão ou sentimento semelhante, e que implica colocar o

${ }^{632}$ Cf. G. GORLA, Il contratto I cit., pp. 98-99: "non vi è, nella realtà della vita, donazione che non sia determinata da un interesse diverso da quello del puro spirito di liberalità", e "Il puro spirito di liberalità è qualcosa di astratto e forse di altrettanto raro quanto l'imperativo categorico di Kant". Cf. também, A. CATAudella, Successioni e donazioni cit., pp. 10-11, G. ConTE, Il contratto di donazione tra liberalità e gratuità cit., p. 22. BESSONE sintetiza bem o problema. Para o autor, o animus donandi "non descrive affatto la realtà delle cose". Seria uma "formula di chiusura di un problema di qualificazione causale", problema este que não pode encontrar solução em um conceito informado por um "apprezzamento psicologico dei fenomeni giuridici", na medida em que aquilo que é psicológico foge a toda forma de controle, cf. M. BESSONE, Adempimento e rischio cit., pp. 236-37.

${ }^{633}$ Cf. A. GIANOLA, Atto gratuito, atto liberale cit., pp. 5-7. 
interesse, a vantagem, o prazer e a felicidade alheios acima do interesse próprio, dentro de uma escala subjetiva de valores ${ }^{634}$.

Na doutrina pátria, por sua vez, as críticas ao reconhecimento de uma acepção psicológica do animus donandi são amplamente difundidas. BODIN DE MORAES, por exemplo, afirma que o animus donandi entendido como "motivo individual e contingente que impulsiona o doador" ou como "elemento psicológico" é "irrelevante, pois depende de questões internas e particulares". É de se reconhecer que são raros os casos em que o donatário é o único a ter benefícios, pois há interesses concretos do doador na doação, ainda que de natureza extrapatrimonial, tanto que a lei permite a sua revogação quando seus interesses não forem levados em consideração ${ }^{635}$.

${ }^{634}$ Além dessas seis hipóteses, GIANOLA acrescenta mais duas, próprias de entidades que não são pessoa física: trata-se de prestações sem contrapartida efetuadas em razão de (vii) determinação legal ou (viii) determinação contida no ato constitutivo, estatuto ou contrato social. A diferença da segunda hipótese com relação à primeira consiste no fato de que, na segunda, o beneficiário não pode exigir diretamente o cumprimento da determinação, embora os administradores possam ser responsabilizados, inclusive perante eventual ente público de controle, cf. A. GiAnOLA, Atto gratuito, atto liberale cit., pp. 5-7.

${ }^{635}$ Cf. M. C. BODIN DE MORAES, Notas sobre a promessa de doação cit., pp. 8-9 e17-18. Para L. C. Penteado, Doação com encargo e causa contratual cit., pp. 341-42, "ninguém doa só por um desinteresse e desprendimento absolutos", mas com base em "interesses outros que não o de liberalidade, como interesses religiosos, familiares ou morais". Para não se ter que "abolir a noção de doação", há "uma intencional não investigação desse conteúdo pela doutrina e jurisprudência". Para A. ALVIM, Da doação cit., pp. 8-10, a doação "se contenta com o rótulo de liberalidade", pois nosso direito não valoriza o motivo íntimo como elemento do contrato. Assim, é possível a existência de doações em que o animus donandi subjetivo não está presente nem mesmo externamente como aparência de liberalidade. $\mathrm{O}$ autor cita como exemplo a doação a um parente que está mal de vida, a quem o doador faz o benefício por não querer ser exceção, sem esconder o fato de ninguém. Para o jurista, em regra, doação supõe liberalidade e se pode dizer que há “intenção de bem-fazer, de proteger”, um sentimento de amor, amizade, religião ou ética. Excepcionalmente, podem, podem existir doações pautadas pelo temor de reprovação, pela vaidade, pela "esperança de vantagens indiretas" ou "como noblesse oblige". F. C. PONTES DE MIRANDA, Tratado de direito privado XLVI cit., pp. 231-33, por sua vez, afirma que "o elemento subjetivo é essencial" para a configuração da doação, mas se deve eliminar a referência aos motivos. P. L. N. LôBo, Comentários ao Código Civil VI cit., pp. 275-76, no mesmo sentido, argumenta que a liberalidade se distingue do motivo, enquanto "móvel totalmente pessoal e concreto do ato volitivo do doador" e "irrelevante para caracterizar o contrato". Para M. H. DINIZ, Curso de direito civil brasileiro III - Teoria das obrigações contratuais e extracontratuais, $27^{\mathrm{a}} \mathrm{ed}$., São Paulo, Saraiva, 2011, pp. 253-54, o "espírito de altruísmo, de desinteresse ou de generosidade não é essencial à noção jurídica de doação", uma vez que "não deixarão de constituir doação as ofertas interesseiras do político que doa seus subsídios para angariar sufrágios", ou "a de empresário que oferece banco ao jardim público de sua cidade contendo propaganda do doador". Segundo N. Rosenvald, Arts. 481 ao 652 Contratos (em espécie) cit., p. 424, doação "não necessita ter como móvel a benemerência ou beneficência", até porque "dificilmente haverá doação isenta de interesse social, ético, político, religioso, científico, desportivo, afetivo, amoroso etc". Afirma: "é fundamental frisar que não há que investigar os motivos da doação". Ainda, cf. S. S. VENOSA, Direito civil III cit., p. 103. 


\section{Sentido objetivo e a irrelevância do espírito de liberalidade}

As críticas deram ensejo à construção de concepções objetivas acerca do animus donandi. Podem ser identificadas duas vertentes, embora não seja possível fazer uma divisão absolutamente estanque, pois se interpenetram - a liberalidade como espontaneidade e a liberalidade como o aspecto subjetivo do enriquecimento ${ }^{636}$. A Exposição de Motivos ao CC de 1942, por exemplo, parece sintetizar ambas ${ }^{637}$, ao definir o animus donandi como a consciência de conferir a outrem uma vantagem patrimonial sem estar obrigado $^{638}$.

A primeira vertente dá mais ênfase à liberdade ou espontaneidade do agente, isto é, à ausência de vinculação ou obrigação de praticar o ato. CASULLI, assim, define o animus donandi como a espontaneidade ou ausência de constrição ${ }^{639}$. É a ideia de que o “ânimo" seria espontâneo, oposto a toda "previsão de necessidade ou dever", isto é, "sem nenhuma obrigação, nullo iure cogente, e só com o fim de beneficiar o donatário"640. É nesse sentido que PONTES DE MIRANDA afirma que o importante é que o doador não deva o que presta e que o donatário não preste em cumprimento de contraprestação ${ }^{641}$.

A ideia guarda relação com a ausência de sinalagma, ou, de uma maneira mais geral, com a ausência de causa pressuposta ou final. Essa primeira vertente sofre a crítica de que a caracterização atribui um sentido meramente negativo e insuficiente, porque obviamente não consegue dar um caráter distintivo à doação com relação aos outros tipos

${ }^{636}$ Cf. P. MOROZZO DElla RoCCA, Gratuità, liberalità e solidarietà cit., pp. 58-59.

${ }^{637}$ Unindo ambas as noções, DINIZ associa o animus donandi ao ânimo de proporcionar "ao donatário certa vantagem à custa do seu patrimônio", o que deve ocorrer em um modo espontâneo, isto é, sem que o doador aja no cumprimento de uma obrigação", cf. M. H. DINIZ, Curso de direito civil brasileiro III cit., pp. 253-54. LÔBO, em sentido semelhante, afirma que a liberalidade traduz-se no ânimo ou consciência "de dar parte do próprio patrimônio para a satisfação econômica de alguém, de dar o que não tem obrigação de dar”, cf. P. L. N. LÔBO, Comentários ao Código Civil VI cit., pp. 275-76.

${ }^{638}$ Cf. D. GRANDI, Relazione del Ministro Guardasigilli al Codice Civile cit., $\mathrm{n}^{\mathrm{o}}$ 372, pp. $77-$ 78. A concepção objetiva do animus donandi também foi desenvolvida na França, e se liga a uma concepção mais objetiva de causa final. O animus donandi seria indiferente aos motivos e interesses morais ou até patrimoniais do doador e se caracterizaria pela consciência ou vontade de beneficiar outro sujeito à custa do próprio empobrecimento ou de não receber contraprestação equivalente, cf. S. LAMBERT, L'intention libérale dans les donations, pp. 218-19, A. JUNQUEIRA DE AZEVEDO, Negócio jurídico e declaração negocial cit., p. 127 e A. SÉRIAUX, Les succession - Les libéralités cit., pp. 103-04. Segundo CAPITANT, trata-se do but perseguido pelo agente, que não se confunde com os motivos individuais, mas varia de acordo com a natureza do negócio, Cf. H. CAPITANT, De la cause des obligations cit., pp. 81-82.

${ }_{639}$ Cf. V. R. CASUlli, Donazione (diritto civile), in ED 13 (1964), p. 968.

${ }^{640}$ Cf. M. C. BODIN DE MORAES, Notas sobre a promessa de doação cit., pp. 3-4.

${ }^{641}$ Cf. F. C. PONTES DE MIRANDA, Tratado de direito privado XLVI cit., pp. 231-33. 
contratuais, e acaba por anular o espírito de liberalidade ${ }^{642}$, até porque a liberdade é uma característica dos atos de autonomia privada em geral $^{643}$.

A segunda vertente dá ênfase ao animus donandi como a vontade ou consciência de enriquecer o donatário ou de se efetuar uma atribuição patrimonial sem contrapartida $^{644}$. Para D'ANGELO, o animus donandi seria a representação intelectual do resultado gratuito como um elemento determinante da vontade, ou seja, o escopo fundamental que a determina. É a intenção voltada ao enriquecimento, cuja função essencial é justificar a tutela jurídica do contrato de doação ${ }^{645}$. Esse animus, para OPPO, existiria também em todos os contratos gratuitos, e consistiria na vontade voltada para a realização do conteúdo das prestações próprias de cada negócio. No caso das liberalidades - tanto a doação quanto outros atos de liberalidade - o "espírito de liberalidade" consistiria na intenção de enriquecer sem contrapartida ${ }^{646}$.

Essa concepção do animus donandi em sua segunda vertente, conforme se pode ver a partir da sua própria definição, é “objetiva” apenas em termos, pois continua atribuindo um papel preponderante à vontade interna na qualificação do negócio, papel esse já denunciado por BETTI como irrelevante ${ }^{647}$. Além disso, pode ser criticada pelo fato de que extirpa a intenção liberal de sua função própria, pois a leva a ser confundida com a vontade ou com o próprio consentimento ${ }^{648}$. E a vontade, conforme afirma JUNQUEIRA DE AZEVEDO, não é elemento de existência do negócio jurídico, só servindo para "influenciar a validade do negócio e às vezes também a eficácia"649.

${ }^{642}$ Cf. A. C. Jemolo, Lo "spirito di liberalità" - Riflessioni su una nozione istituzionale, in VVAA, Studi in memoria di Filippo Vassalli II, Torino, UTET, 1960, pp. 979-80.

${ }^{643} \mathrm{Cf}$. G. CONTE, Il contratto di donazione tra liberalità e gratuità cit., p. 20; G. B. FERRI, Dall'intento liberale al cosidetto impegno etico e superetico cit., p. 70.

${ }^{644}$ Cf. A. PAlazzo, Atti gratuiti e donazioni, in R. SACCO (org.), Trattato di diritto civile - I singoli contratti II, Torino, UTET, 2000, p. 121. Entre nós, GOMES define o animus donandi como "a intenção de praticar um ato de liberalidade" ou "o intuito de enriquecer o beneficiário", no sentido de "vontade desinteressada de fazer benefício a alguém, empobrecendo-se ao proporcionar à outra parte uma aquisição lucrativa causa", cf. O. GOMES - A. JUNQUEIRA DE AZEVEDO - F. P. D. C. MARINO, Contratos cit., p. 256.

${ }^{645}$ Cf. A. D’Angelo, La donazione rimuneratoria, Milano, Giuffrè, 1942, pp. 15-22.

${ }^{646}$ Cf. G. OPPO, Adempimento e liberalità cit., pp. 288-89.

${ }^{647}$ Cf. E. BETTI, Teoria generale del negozio giuridico cit., pp 57 e 176, principalmente.

${ }^{648}$ Cf. S. LAMBERT, L'intention libérale dans les donations, pp. 218-19, A. JUNQUEIRA DE AZEVEDO, Negócio jurídico e declaração negocial cit., p. 127 e A. SÉRIAUX, Les succession-Les libéralités cit., pp. 103-04.

${ }^{649}$ Cf. A. JUNQUEIRA DE AZEVEDO, Negócio jurídico cit., p. 82. 
É a crítica feita pelos anticausalistas franceses, que entendem que aquilo que se chamou de causa é o próprio consentimento, ou seja, a manifestação de vontade necessária para a formação do contrato ${ }^{650}$. Para PlANiol, por exemplo, o que se chama de causa da doação nada mais é do que a vontade de doar, considerada abstrata e independentemente dos motivos que teriam dado ensejo a ela ${ }^{651}$. Segundo MANZINI, a concepção levaria ao ponto de se negar autônoma relevância ao animus donandi, pois se confunde com a própria vontade negocial, isto é, com o próprio exercício da autonomia privada. Dessa maneira, esvazia-se a sua importância, pois nenhuma conotação ulterior se pode adicionar ao "enriquecimento" de uma parte através da disposição de um direito ou assunção de uma obrigação $^{652}$.

OPPo, até tenta, antevendo a crítica, afirmar que o elemento subjetivo juridicamente relevante do negócio não se exaure na vontade, mas inclui o motivo último ou a razão do querer ${ }^{653}$. Porém, ele próprio não consegue escapar da contradição, pois ao afirmar que tal elemento particular está presente em todos os contratos gratuitos, acaba levando à conclusão de que não se trata de elemento essencial caracterizador da doação, pois não tem uma função particular específica para esse contrato.

Em razão dessas dificuldades, destaca-se no direito italiano uma doutrina que prega a irrelevância do animus donandi para a caracterização da doação ${ }^{654}$. BALBI, após apresentar críticas às diversas concepções, afirma que não compreende porque se deveria exigir uma posição subjetiva particular diversa da vontade contratual. Da mesma forma que na compra e venda o elemento subjetivo se exaure na vontade comum das partes, na doação ele se exaure na vontade concorde em realizar uma atribuição gratuita em favor do donatário $^{655}$.

${ }^{650}$ Cf. H. CAPITANT, De la cause des obligations cit., pp. 81-82.

${ }^{651}$ Cf. M. F. PLANIOL, Traité élémentaire de droit civil conforme au programme officiel des facultés de droit II - Les preuves. Théorie générale des obligations. Les contrats. Prtivilèges et hypothèques, $2^{\mathrm{a}}$ ed, Paris, Cotillon, 1902, pp. 319 e 322. donandi cit., p. 413.

${ }^{652}$ Cf. C. MANZINI, "Spirito di liberalità" e controllo giudiziario sull'esistenza della causa

${ }_{653}$ Cf. G. OPPO, Adempimento e liberalità cit., pp. 76-79, nt.1.

${ }^{654}$ BISCONTINI destaca que o problema não é discutir o significado do animus donandi, mas se deve ser entendido como essencial à qualificação da doação. Sua conclusão é que o espírito de liberalidade "non può assurgere ad elemento qualificante la fattispecie", cf. G. BISCONTINI, Onerosità, corrispettività e qualificazione dei contratti cit., p. 140 e 151.

${ }^{655}$ Cf. G. BALBI, Saggio sulla donazione cit., p. 74. 
Para BIONDI, o legislador retomou o antigo animus donandi dos romanos sem indagar se isso faria algum sentido em um sistema em que a doação é o negócio típico de liberalidade. Em razão da dificuldade de se distinguir a vontade de doar de uma qualificação especial dessa vontade, o espírito de liberalidade acaba sendo uma "superfetação", que só adquirirá verdadeiramente relevância para as liberalidades diversas do contrato de doação, pois retomará a função que tinha no direito romano ${ }^{656}$.

Em sentido semelhante, MIRABELLI chega ao ponto de negar toda importância ao animus donandi no caso de doações não motivadas ou puras, afirmando que estas exigem somente a forma solene e nada mais ${ }^{657}$. A afirmação parece curiosa, pois dá a entender que a forma solene, de certa forma, substitui o animus donandi como elemento caracterizador da doação. Prenuncia, com efeito, a teoria que será vista a seguir (III.4).

cf. II.6.1.

${ }^{656}$ Cf. B. BIONDI, Le donazioni cit., pp. $94-95$ e 101. Sobre as liberalidades diversas da doação,

${ }^{657}$ Cf. G. MIRABELLI - S. PICCININI, Dialoghi in tema di liberalità, in VVAA, Scintillae iuris Studi in memoria di Gino Gorla III - Contratto, responsabilità, proprietà, impresa e società, processo, amministrazione pubblica, Milano, Giuffrè, 1994, p. 1945. 


\section{Forma prescrita em lei como elemento caracterizador da doação}

\section{Forma como substituta da causa}

No tópico anterior, foi mencionada uma afirmação de MIRABELLI de que o animus donandi é desnecessário para caracterizar a doação pura, pois basta a forma solene e nada mais. Essa ideia está relacionada a uma concepção da doação que teve seu desenvolvimento na Itália com a obra de GORLA e, entre nós, foi seguida por PENTEAdo. Parte considerável da doutrina italiana atual, entretanto, não aceita essa concepção.

Um bom ponto de partida para entender essa concepção é a distinção feita por JUNQUEIRA DE AZEVEDO entre as causas pressuposta e final (embora esse autor não seja adepto da concepção de que tratará este tópico). Os negócios jurídicos causais se subdividem em negócios com causa pressuposta e em negócios com causa final. A causa não seria elemento de existência do negócio jurídico, mas requisito de validade no caso da causa pressuposta e fator de eficácia no caso da causa final ${ }^{658}$.

Nos negócios com causa pressuposta, esta é um fato logicamente anterior que o justifica, como aqueles celebrados para cumprimento de uma dívida já existente, como confissão de dívida, novação, delegação e dação em pagamento ${ }^{659}$. Nos negócios com causa final, a causa é um fato futuro ao qual o negócio tende, como a contraprestação nos negócios sinalagmáticos ${ }^{660}$.

$\mathrm{Na}$ doação, como se pode perceber, é difícil identificar tanto uma causa pressuposta quanto uma causa final. E mais, a doação simples seria um negócio causal em que o animus donandi "faz as vezes de causa pressuposta" ${ }^{661}$, de maneira semelhante à que já fazia DOMAT, resolvendo o problema de eventual invalidade. PENTEADO, entretanto, não aceita essa concepção segundo a qual o espírito de liberalidade ou animus donandi ocupa o lugar da causa pressuposta - que chama de "causa natural". Na linha das críticas já vistas

154-55.

${ }^{658}$ Cf. A. JunQueIRA DE AZEVEdo, Negócio jurídico cit., pp. 140 e 147-50 e nt. 221, 152 e

${ }^{659}$ A ideia de causa pressuposta guarda relação com o que BETTI denomina causa remota, isto é, um pressuposto objetivo da causa típica (abstrata) que caracteriza o negócio. O exemplo dado é a atribuição que é feita em cumprimento a uma obrigação preexistente, cf. E. BETTI, Teoria generale del negozio giuridico cit., p. 176.

${ }^{660}$ Cf. A. Junqueira de AzEvedo, Negócio jurídico cit., pp. 140 e 147-50 e nt. 221, 152 e 154-55.

${ }^{661}$ Cf. A. JUNQUEIRA DE AZEVEDO, Negócio jurídico cit., p. 148, nt. 220. 
acerca desse requisito subjetivo, o autor conclui que "ninguém doa só por um desinteresse e desprendimento absolutos", de maneira que é inaceitável a teoria da causa construída com base no subjetivismo ${ }^{662}$.

Sobre a questão, o autor afirma, por um lado, que deve haver sempre "um requisito estrito para admitir a doação", e por outro, que a doação pura "carece de causa natural", pois "não há uma contrapartida prestada pelo donatário" que "exerça o papel de justificar a atribuição gratuita que ele receber" $" 663$. Em outras palavras, faltaria, na doação, uma causa de juridicidade consistente na entrega de uma coisa ou na contraprestação.

A causa, no entendimento de Penteado, é o fundamento de um dever, o elemento concreto que justifica uma obrigação assumida ${ }^{664}$. Trata-se da premissa encontrada em GORLA de que "solus consensus non obligat" 665 . Este autor repropõe para o direito moderno a questão do nudum pactum do direito romano - trata-se de um "nuovo sistema di patti" - e reafirma a necessidade de uma cause suffisante para vincular as partes. Assim, na ausência de causa, a obrigação de dar a título gratuito seria uma primeira limitação ao princípio do consensualismo ${ }^{666}$.

No caso da doação, todavia, a forma solene, como um vestimentum, ocupa o lugar da causa e garante juridicidade ao acordo ${ }^{667}$. Segundo CONTE, esse filão doutrinário resolveu no plano "formal" as questões que não eram passíveis de serem resolvidas no plano "funcional"668. Essa ideia é expressa de maneira muito clara em uma muito citada afirmação de SACCO e DE Nova: "Quando la causa è debole perché fondata su un

\footnotetext{
${ }^{662}$ Cf. L. C. PENTEADO, Doação com encargo e causa contratual cit., pp. 341 e 413 e N. NERY JR. - L. C. PENTEADO, Doação pura, preliminar de doação e contratos de gestão cit., pp. 16-17.

${ }^{663}$ Cf. L. C. PENTEADO, Doação com encargo e causa contratual cit., pp. 208 e 341.

${ }^{664}$ Cf. L. C. PENTEADO, Doação com encargo e causa contratual cit., pp. 412-13.

${ }^{665} \mathrm{Cf}$. G. CONTE, Il contratto di donazione tra liberalità e gratuità cit., p. 48.

${ }^{666} \mathrm{Cf}$. G. GoRLA, Il contratto I cit., pp. 81-82.

${ }^{667}$ Cf. G. GORLA, Il contratto I cit., pp. 92-94.

${ }^{668}$ Cf. G. CONTE, Il contratto di donazione tra liberalità e gratuità cit., p. 25.
} 
desiderio soggettivo, la forma salva il negozio" ${ }^{669}$. Assim, não é o animus donandi que faz as vezes da causa, mas a forma prescrita em $1 \mathrm{ei}^{670}$.

Para Penteado, nos contratos a ideia de causa e a de sinalagma são coextensivas. A ausência de contraprestação implica a necessidade de outro critério para se aferir a intenção de se obrigar juridicamente. No caso dos contratos reais, há uma analogia entre a entrega da coisa e o sinalagma. Já no caso da doação, a forma prescrita em lei atua como causa civil, que supre a falta da contraprestação e faz com que haja, de lege lata, coerência com a estrutura contratual dada pela lei, uma vez que não há uma prestação dada - contratos reais - ou prometida - contratos sinalagmáticos ${ }^{671}$.

\section{Doação como negócio quase abstrato}

A atribuição desse papel tão essencial à forma, todavia, apresenta a dificuldade de fazer com que a doação se aproxime muito dos negócios abstratos, embora não haja dúvidas, para CONTE, de que seja um contrato sujeito ao "princípio da causalidade" adotado pelo Código de $1942^{672}$. Já foi mencionado que os elementos de existência intrínsecos aos negócios jurídicos, para JUNQUEIRA DE AZEVEDO, seriam a forma, o objeto e as circunstâncias negociais. Essas circunstâncias são a "essência de todo e qualquer negócio", aquele "padrão cultural” que "faz com que a declaração seja vista socialmente como dirigida à criação de efeitos jurídicos”, as circunstâncias negociais ${ }^{673}$. Essa noção, aliás, aproxima-se da ideia de BETTI de que, sendo o negócio jurídico um fato social e a

${ }^{669}$ Cf. R. SACCO - G. De Nova, Il contratto I, $3^{\text {a }}$ ed., in R. SACCO (org.), Trattato di diritto civile - Le fonti delle obbligazioni I, Torino, UTET, 2004, p. 799. No mesmo sentido, cf. C. ARGIROFFI, Il formalismo e la donazione in, A. GALASSO - S. MAZZARESE (org.), Il principio di gratuità cit., especialmente p. 149.

${ }^{670}$ Cf. L. C. PENTEAdo, Doação com encargo e causa contratual cit., pp. 341 e 413 e N. NERY JR. - L. C. PENTEADO, Doação pura, preliminar de doação e contratos de gestão cit., pp. 16-17. Para esses autores, também ocupa o lugar de causa a entrega efetiva e real da coisa na doação manual (art. 541, parágrafo único). MOROZzo DELlA ROCCA bem sintetiza a posição de GorlA. Partindo do pressuposto de que o pacto nu é inidôneo a obrigar o promitente ao cumprimento da promessa, essa vinculatividade depende de um vestimentum. A contraprestação é um desses vestimenta, assim como a forma solene e a entrega da coisa nos contratos não onerosos, cf. P. MOROZZO DELlA RoCCA, Gratuità, liberalità e solidarietà cit., p. 51.

${ }^{671}$ Cf. L. C. PENTEADO, Doação com encargo e causa contratual cit., pp. 412-13. No mesmo sentido, para NERY e PENTEADO a forma "exerce a função da causa nos contratos sinalagmáticos, não sendo a causa o mero animus donandi desprovido de outras qualificações”, cf. N. NERY JR. - L. C. PENTEADO, Doação pura, preliminar de doação e contratos de gestão cit., p. 31 .

${ }^{672} \mathrm{Cf}$. G. CONTE, Il contratto di donazione tra liberalità e gratuità cit., p. 48.

${ }^{673}$ Cf. A. JUNQUEIRA DE AZEVEDO, Negócio jurídico cit., pp. 122, 134, 136 e 140. 
autonomia privada um fenômeno social, o negócio deve atender a uma exigência de reconhecimento social que domina toda a sociedade, isto é, deve ser um fato socialmente reconhecível $^{674}$.

Segundo JUNQUEIRA DE AZEVEDO, como as circunstâncias negociais são invariáveis em todas as categorias de negócio, as variações entre elas se darão em razão dos dois outros elementos. Assim, há negócios que se caracterizam pela forma - os negócios abstratos - e negócios que se caracterizam pelo objeto - negócios causais ${ }^{675}$. Nos negócios abstratos, a forma será seu elemento de existência. Sua falta não acarreta apenas a nulidade, como nos negócios causais com forma prescrita em lei (art. 104, III e art. 166, IV), mas a sua "inexistência como aquele negócio"676.

Para PENTEADO, em artigo escrito em conjunto com NERY, a doação qualificase por um esquema formal-causal, pois a forma não é mero requisito de validade, mas vestimentum, isto é, um dado objetivo que é justificador da tutela de direito. Assim, a doação "tem por elemento nuclear a forma, sem a qual é inexistente". A forma é "da substância do ato", do mesmo modo que nos títulos de crédito abstratos, o que leva à conclusão de que "uma doação pura sem forma não existe juridicamente como doação"677.

Segundo os autores, embora normalmente a forma prescrita em lei seja requisito de validade, em alguns atos, como nos títulos de crédito, é tão importante que passa a ser o elemento categorial inderrogável que caracteriza o negócio. Como a forma

${ }^{674}$ Cf. E. BETTI, Teoria generale del negozio giuridico cit., p. 55.

${ }^{675}$ Cf. A. JunQUeIRA DE AZEVEDO, Negócio jurídico cit.., pp. 122, 134, 136 e 140. O termo "negócio causal" poderia induzir ao entendimento de que é um negócio que se caracteriza pela causa. Porém, na concepção de JUNQUEIRA DE AZEVEDO, enquanto a causa "é um fato externo ao negócio, mas que o justifica do ponto de vista social e jurídico", o elemento categorial objetivo "é justamente a referência, que se faz a esse fato, no próprio conteúdo do negócio" (pp. 140, 147-50 e nt. 221).

${ }^{676}$ Cf. A. JunQueIRA DE AZEVEDO, Negócio jurídico cit., pp. 140-41 e 143.

${ }^{677}$ Cf. L. C. PENTEADO, Doação com encargo e causa contratual cit., pp. 291-92 e N. NERY JR. - L. C. PENTEADO, Doação pura, preliminar de doação e contratos de gestão cit., pp. 19-20 e 31-32. Para os autores, o art. 109 do CC br. consagrou a forma como elemento de existência no direito brasileiro, embora a redação seja imprecisa ao falar em "cláusula de não valer sem instrumento público". Esses autores se referem a essa forma como aquela ad substantiam. Para JUNQUEIRA DE AZEVEDO, todavia, a expressão forma ad substantiam ou ad solemnitatem é a forma prescrita cujo "descumprimento acarreta nulidade". A ela se opõe a forma ad probationem tantum, que caracterizava, antes do CC de 1916, aqueles negócios "que somente se podiam provar por escrito". Para o autor não faz mais sentido a distinção no direito atual, cf. A. JunQUEIRA DE AZEVEDo, (parecer) Depósito de ouro e pedras preciosas feito em 1878. Forma e prova do contrato de depósito. Depósito mercantil e depósito bancário. Mora do credor, in Estudos e pareceres de direito privado, São Paulo, Saraiva, 2004, p. 252. 
ocupa o lugar da causa no sentido de contraprestação, a sua falta afeta a qualificação do ato.

A doação não deixa de ser negócio causal, pois "importa qual seja o objeto". O que há é uma exceção à regra geral dos negócios causais segundo a qual a ausência de forma implica nulidade. A conclusão é que "a doação tem dois elementos categoriais inderrogáveis, um formal e outro objetivo: a forma escrita e a gratuidade da transferência efetiva do bem". Portanto, "sem forma ou sem transferência gratuita efetiva não há contrato de doação e, portanto, a qualificação demanda invocar outro nomen iuris que não esse, 678 .

É interessante mencionar um interessante acórdão do STJ, proferido recentemente no julgamento do AgRg no AREsp 228.629 ${ }^{679}$. Trata-se de alegada doação de imóvel que o tribunal entendeu não estar demonstrada em razão da ausência de escritura pública ou instrumento particular. Dois aspectos merecem destaque. Por um lado, o acórdão faz referência à forma como condicionante da "existência da doação", o que parece corroborar a posição que acaba de ser vista neste trabalho de que a forma prescrita em lei seria elemento de existência, e não requisito de validade da doação. Por outro lado, todavia, o acórdão admite que a "demonstração do animus donandi" supra a ausência de forma.

Veja-se a afirmação que consta do voto do Relator Min. Raul Araújo: “o reconhecimento da existência de doação, nos casos em que não houve o seu registro (sic) [“escritura pública ou instrumento particular", como constou em trecho anterior o mesmo voto], depende da demonstração do animus donandi, o que não ficou configurado diante dos fatos narrados nos autos". A conclusão é interessante. Se para a concepção doutrinária aqui vista a forma substituiria a causa e "salvaria" o negócio (SACCO e DE NovA), o STJ admite a possibilidade de o animus donandi (!) suprir a ausência de forma e, igualmente, "salvar" o negócio. Vê-se como é difícil afastar-se do requisito subjetivo.

${ }^{678}$ Cf. N. NERY JR. - L. C. PENTEADO, Doação pura, preliminar de doação e contratos de gestão cit., pp. 18 e 20-21. PICCININI, seguindo construção semelhante, afirma que a ideia que esclarece mais perfeitamente o conceito de doação é de que a forma substitui a causa ausente ou insuficiente. A consequência disso é que a doação é um ato "acausale" e formal, cf. S. PICCININI, Profili della donazione dal codice 1865 ad oggi cit., pp. 189-91.

${ }^{679}$ Cf. STJ, 4 a Turma, AgRg no AResp 228.629-PR, Rel. Min. Raul Araújo, j. 26.05.2015. 


\section{Críticas à concepção que dá preponderância à forma como elemento da doação}

A concepção que acabou de ser vista vem sofrendo uma série de críticas. Em primeiro lugar, em razão da relevância dada à forma solene, que seria "un relitto storico" 680 . Em segundo lugar, porque "nenhuma confusão é possível entre o elemento categorial inderrogável próprio dos negócios abstratos (a forma típica) e a causa” ${ }^{\text {681 }}$. Para os críticos, tanto a causa quanto a forma têm funções específicas. A forma seria um modo de expressão do negócio e não uma "sanção" da juridicidade do vínculo. A tese atacada, se levada às últimas consequências, implicaria dizer que o controle sobre a juridicidade do vínculo esgota-se na higidez formal, o que não parece ser razoável ${ }^{682}$.

Em terceiro lugar, a concepção é elaborada com base em uma visão muito restrita de liberdade contratual, baseada em sistemas antigos, como o romano, em que os contratos eram típicos ${ }^{683}$. Essa concepção não poderia subsistir, ante o princípio da autonomia contratual consagrado pelo art. 1.322 do CC de 1942, que consagra a

${ }^{680}$ Cf. A. PAlAZZO, Atti gratuiti e donazione cit., p. 125. Esse autor afirma que não se contrapõe propriamente à posição de GORLA, mas entende que a presença de certos motivos objetivados no ato tutelam os interesses do doador e do donatário mais do que até mesmo a forma pública. Também cf. A. Palazzo, Donazione, in Dig. disc. pric., Sez. civ. 7 (1991), pp. 140-41 e A. Palazzo, Le donazioni, in P. SCHLESINGER (org.), Il Codice Civile - Commentario - Artt. 769-809, Milano, Giuffrè, 1991, pp. 11-12. Segundo o jurista, o expresso reconhecimento no art. 809 das liberalidades diversas da doação, não sujeitas à regra de forma, é a prova mais extrema de que a posição substancial da forma no contexto da doação é relativa, cf. A. PALAZZO, Contenuto e forma, in A. PALAZZO (org.), I contratti di donazione, in P. RESCIGNO - E. GABRIELl, Trattato dei contratti XI, Torino, UTET, 2009, p. 60.

${ }^{681}$ Cf. A. JUNQUEIRA DE AZEVEDO, Negócio jurídico cit., p. 149 e nt. 222.

${ }^{682}$ Cf. L. BOZZI, Alla ricerca del contratto gratuito atipico cit., pp. 228-29. No mesmo sentido, MOROZZO DELLA ROCCA afirma que o próprio fato de o legislador ter prescrito tanto a causa quanto a forma como requisitos do contrato (art. 1.325) evidencia que a forma não é substituta da causa, mas tem função própria, cf P. MOROZZO DELlA ROCCA, Gratuità, liberalità e solidarietà cit., p. 55. Para BISCONTINI, mesmo se for adotada sua concepção de doação como "tipo contrattuale di chiusura" (cf. II.4.2) não será possível ver a doação como negócio "acausale" ou abstrato, pois sua estrutura contratual determinada em lei não o consente. Além disso, não se pode relacionar a forma solene à função típica da doação, pois entender que a forma garante "juridicidade" ao acordo não resolve o problema da sua qualificação. E o que caracteriza a sua função é a produção de um efeito real ou obrigatório sem correspectivo, cf. G. BISCONTINI, Onerosità, corrispettività e qualificazione dei contratti cit., pp. 167-71. Faz-se apenas a ressalva de que GoRLA não via a causa como função econômico-social do negócio (que irá, para alguns, definir o tipo) mas como causa de juridicidade da obrigação (ou da prestação). BISCONTINI parece misturar os diversos sentidos de causa, cf. II.2.

${ }^{683}$ PALAZZO, em sentido contrário, sustenta que essa visão restrita não teria origem propriamente no direito romano, mas em preconceitos de natureza dogmática que têm origem nas "riflessioni giusnaturalistiche" de DOMAT, cf. A. PALAzZO, Strutture e funzioni della liberalità, in A. GALASSO - S. MAZZARESE (org.), Il principio di gratuità cit., pp. 204-06. 
possibilidade de celebração de contratos atípicos ${ }^{684}$. Basear-se-ia, além disso, em uma concepção antiquada de causa, que não a vê como função e nem mesmo como causa de atribuição patrimonial, mas como justificativa da vinculatividade ou juridicidade do pactum, que coloca uma limitação ao princípio do solus consensus obligat ${ }^{685}$.

Trata-se, além de tudo, de uma concepção de causa como causa da prestação e não como causa do negócio jurídico, o que leva a doutrina a procurar incessantemente um nexo de causalidade que justifique o surgimento de um vínculo obrigacional, num contrato em que a prestação de uma parte não pode encontrar sua justificativa na obrigação da outra $^{686}$.

Já BETTI afirmava que "solo una visione atomistica che spezza l'unità del negozio e considera questo dal punto di vista unilaterale di ciascuna parte, può giungere a ravvisare la causa nella controprestazione" e essa "prospettiva unilaterale è palesemente erronea" ${ }^{687}$. E no caso da doação, a ausência de contraprestação tornaria, segundo FERRI, o problema da identificação de sua causa praticamente insolúvel.

Se, ao contrário, a causa for vista como a função do negócio como um todo, tornar-se-ia desnecessária a busca por um substituto da contraprestação que garanta juridicidade ao vínculo. Esta juridicidade seria garantida através de um controle acerca da causa concreta, ou da função econômico-individual ${ }^{688}$. Nesse sentido, o negócio concretamente celebrado será admitido sempre que haja correspondência entre o regulamento dos interesses das partes e os princípios do ordenamento ${ }^{689}$.

${ }^{684}$ Cf. G. CONTE, Il contratto di donazione tra liberalità e gratuità cit., p. 48.

${ }^{685}$ Cf. L. BozzI, Alla ricerca del contratto gratuito atipico cit., pp. 228-29. GoRLA também é criticado por propor uma leitura "anglossassone" da função da causa, que é própria do direito continental, aproximando-a demais da consideration, cf. P. MOROZzO DELLA ROCCA, Gratuità, liberalità e solidarietà cit., p. 54.

${ }^{686}$ Cf. G. B. FerRI, Causa e tipo nella teoria del negozio giuridico cit., pp. 78-81.

${ }^{687}$ Cf. Cf. E. BETTI, Teoria general del negozio giuridico cit., p. 179.

e 77.

${ }^{688}$ Cf. G. B. FERRI, Dall'intento liberale al cosiddetto impegno etico e superetico cit., p. 73-74

${ }^{689}$ Cf. L. BozZI, Alla ricerca del contratto gratuito atipico cit., pp. 228-29. 


\section{Espírito de liberalidade entre interesses e deveres}

\section{Interesses patrimoniais e extrapatrimoniais}

Em meio à discussão sobre a relevância ou não do animus donandi para caracterizar a doação, vem ganhando adeptos - discretamente, segundo CONTE - uma doutrina que dá novo sentido e relevância ao espírito de liberalidade para a caracterização da doação ${ }^{690}$. Seu primeiro defensor parece ter sido CHECCHINI, para quem o foco da análise deve ser na natureza dos interesses que levaram o doador a doar - se patrimoniais ou extrapatrimoniais ${ }^{691}$.

Segundo esse autor, tanto a doutrina que defende o sentido objetivo do animus donandi quanto a que prega sua irrelevância olham para a vontade das partes voltada para a produção dos efeitos próprios do negócio, que o caracterizam enquanto tal. Para

${ }^{690}$ Cf. G. CONTE, Il contratto di donazione tra liberalità e gratuità cit., p. 27. Trata-se da necessidade de estabelecer distinções funcionais entre doações (e atos gratuitos em geral) inseridas na lógica do mercado e doações praticadas em atenção a interesses diversos. É consequência também da insuficiência da distinção entre atos gratuitos e doação somente com base na natureza da prestação (dare ou facere), cf. P. MOROZZO DELLA ROCCA, Gratuità, liberalità e solidarietà cit., p. 56. Um dispositivo bastante emblemático, que demonstra a valorização dos interesses, é o art. 1.174 do CC italiano, que dispõe que "la prestazione che forma oggetto dell'obbligazione deve essere suscettibile di valutazione economica e deve corrispondere a un interesse, anche non patrimoniale, del creditore". Segundo BISCONTINI, tal referência demonstra que o ordenamento jurídico considera relevantes (merecedores de tutela), além do interesse econômico, aqueles interesses morais, sociais, religiosos etc., cf. G. BISCONTINI, Onerosità, corrispettività e qualificazione dei contratti cit., pp. 44-46. Para esse autor, não se pode interpretar a "irrelevância dos motivos" como "irrelevância de interesses não econômicos". Todavia, coloca-se contrário à tese de CHECCHINI, pois os interesses não patrimoniais não seriam suficientes para fornecer elementos inequívocos para a determinação da fattispecie da doação, ou seja, não teriam condições de precisar "la minima unità effetuale del contratto di donazione", pelo fato de serem comuns a outras fattispecie, cf. G. BISCONTINI, Onerosità, corrispettività e qualificazione dei contratti cit., pp. 147-49. D’ETTORE também é crítico da posição de CHECCHINI, e afirma que, além do enriquecimento, é suficiente para a existência da doação a intenção de enriquecer, que seria o animus donandi, não sendo necessária a intenção de satisfazer um interesse extrapartimonial, cf. D'ETTORE, Intento di liberalità e attribuzione patrimoniale cit., pp. 64-66.

${ }^{691}$ Segundo DEL NERO, todo processo deliberativo pressupõe, além do conhecimento dos fatos e do direito, a escolha do meio e a eleição de um fim a ser alcançado. Esse fim não necessariamente diz respeito a "consequências puramente jurídicas, mas também, e antes de mais nada", à "busca da satisfação de necessidades ou interesses, de índoles diversas, embora correlativas". Nesse sentido, o fim como "concretização das consequências jurídicas" (fim jurídico), que no caso da doação é a atribuição sem contrapartida, é meio para o fim enquanto satisfação dos interesses (fim prático), que podem ser os mais diversos. A concepção dita objetiva de animus donandi, que o relaciona à atribuição de vantagens sem contrapartida, relaciona-se ao fim jurídico, isto é, às consequências jurídicas previstas em lei. A nova concepção procura dar relevância ao fim prático enquanto presença ou ausência de interesses econômicos. Ao se buscar atribuir um significado juridicamente relevante ao "espírito de liberalidade", faz-se um juízo acerca da adequação ou não entre fim prático e meio (fim jurídico) cuja consequência é: a presença de interesses patrimoniais exclui a qualificação do negócio como doação. Cf. J. A. S. DEL NERo, Conversão substancial do negócio jurídico cit., pp. 58-65. 
CHECCHINI, em contrapartida, o animus donandi é a razão para essa vontade, é um motivo expresso ou resultante do comportamento negocial que leva as partes a contratarem.

Não se trata de buscar um motivo psicológico como o "puro prazer de beneficiar" ${ }^{692}$, mas algo que objetivamente revele a coligação entre os efeitos essenciais próprios do negócio e o escopo para o qual se volta a vontade tendo em vista um interesse "sottostante" do sujeito. E esse interesse deve ser comum, isto é, conhecido e compartilhado pela outra parte, o que não significa que o interesse seja também do donatário, mas basta que seja aceito por ele ${ }^{693}$.

CHECCHINI propõe uma hipótese de trabalho em que define os atos praticados por espírito de liberalidade como aqueles voltados a satisfazer um interesse não patrimonial do sujeito que dispõe do direito ou assume uma obrigação. Dessa forma, é irrelevante a existência de uma intenção específica de beneficiar, um espírito altruísta ou mesmo a existência de interesses egoístas como a ambição e a vaidade. É suficiente que o escopo não seja o de satisfazer um interesse econômico, mas um interesse não patrimonial, qualquer que seja ele ${ }^{694}$.

LENZI sintetiza bem a teoria. Segundo este autor, "ciò che vivifica e caratterizza in termini di donazione un'attribuzione patrimoniale gratuita è lo spirito di

${ }^{692}$ Cf. III.3.1.

${ }^{693}$ Cf. A. ChecChInI, L'interesse a donare cit., pp. 258-59 e 269, nt. 51. Para o autor, o animus donandi deve revelar "il collegamento sussistente fra gli effeti essenziali perseguiti e lo 'scopo' per cui si è manifestata la volizione in vista di un interesse sottostante del soggetto o dei soggetti". Segundo BESSONE, o fato de o CC ter dado relevância para o erro sobre o motivo da doação, isto è quando "risulta dall'atto ed è il solo che ha determinato il donante a compiere la liberalità" já demonstra que a área dos interesses aos quais a lei atribui relevância "non si esaurisce con quelli che si identificano nella scelta del tipo". E mais, o modo como a regra foi redigida demonstra que a lei não deu relevância excepcional a "rappresentazioni mentali" ou elementos psicológicos. O grande problema, apontado pelo autor, é a identificação de quais são os interesses que devem ser considerados juridicamente relevantes - isto é, que estão entre os motivos juridicamente irrelevantes e aqueles que integram a função econômico-social abstrata do negócio, cf. M. BESSONE, Adempimento e rischio cit., p. 227 e 244-45.

${ }^{694}$ Cf. A. CHECCHINI, L'interesse a donare cit., pp. 262-63. MorOzZO DELLA RoCCA estende a ideia a todos os atos de liberalidade. Ao contrário dos atos gratuitos, que se caracterizam objetivamente pela gratuidade fixada na estrutura da operação negocial visada pelas partes, os atos de liberalidade são caracterizados pela natureza dos interesses envolvidos. Isso significa que a presença de interesses evidentemente patrimoniais não descaracteriza um negócio como gratuito. No caso das liberalidades, poderse-ia até mesmo cogitar de sua prática por meio de negócios onerosos, pois o que efetivamente as caracteriza é a ausência de interesse patrimonial, cf. P. MOROzZO DELLA RoCCA, Gratuità, liberalità e solidarietà cit., pp. 23-24. 
liberalità, che tuttavia non va inteso come pura 'generosità', ma va esteso a tutte le ipotesi in cui il disponente persegua un interesse non patrimoniale" ${ }^{\text {,695. }}$.

A teoria é defendida por autores que sustentam que a doação tenha por objeto prestações de fazer (ou não fazer) ${ }^{696}$. Nesse caso, se a natureza da prestação não serve para diferenciar a doação dos contratos gratuitos atípicos, propõe-se a diferença com base nos interesses envolvidos, de maneira que aqueles negócios praticados em atenção a interesses patrimoniais ficam excluídos do âmbito e da disciplina jurídica da doação, inclusive quanto à forma solene ${ }^{697}$. Nesse sentido, afirma CHECCHINI que admitida a doação que tenha objeto o fazer além do dar, e admitida a categoria dos contratos gratuitos atípicos, o espírito de liberalidade compreendido dessa forma é que servirá para diferenciar a doação obrigatória de tais contratos gratuitos atípicos ${ }^{698}$.

A nova concepção tem duas vertentes, uma que restringe e outra que amplia o âmbito da doação. Para a primeira, deve-se verificar positivamente o interesse extrapatrimonial ou não econômico perseguido pelo doador, que emerge concretamente da doação. MANZINI, nesse sentido, ressalta que tal interesse deve ser objetivado no ato de modo a ser socialmente perceptível, e deve realizar-se através de uma atribuição de caráter econômico que coincida com o "enriquecimento" característico do contrato de doação ${ }^{699}$.

${ }^{695}$ Cf. R. LENZI, Donazione obbligatoria cit., p. 1632.
${ }^{696}$ Cf. II.4.2.
${ }^{697}$ Cf. G. CONTE, Il contratto di donazione tra liberalità e gratuità cit., pp. 27-28. Não haveria somente uma dicotomia entre os negócios gratuitos e onerosos, mas uma tripartição entre os negócios onerosos, os negócios gratuitos economicamente interessados e os atos de liberalidade, dentre os quais estaria a doação, cf. P. MOROZZO DELlA RoCCA, Gratuità, liberalità e solidarietà cit., pp. 65-66. Algo do gênero se pode inferir, no direito brasileiro, a partir da disciplina do contrato de transporte de pessoas, em que o art. 736 afirma que "não se subordina às normas do contrato de transporte o feito gratuitamente, por amizade ou cortesia", e por outro lado, "não se considera gratuito o transporte quando, embora feito sem remuneração, o transportador auferir vantagens indiretas". O CC afirma que entre um contrato de transporte gratuito e um contrato oneroso, há um terceiro gênero, no qual não há contraprestação, mas há interesses econômicos do transportador. Não se pode desconsiderar, todavia, que às relações de amizade e cortesia vêm sendo dado um preciso significado, cf. III.5.3.

${ }^{698}$ Cf. A. CHECCHINI, L'interesse a donare cit., pp. 264-68. RopPo, ao lado dos contratos onerosos e gratuitos, trata da dicotomia entre contratos "liberais" e "interessados", cf. V. RoPPO, Il contratto, in G. IUdiCA - P. ZATTI (org.), Trattato di diritto privato, Milano, Giuffrè, 2001, p. 437. Caso seja adotado o critério distintivo de CHECCHINI, parece que os chamados contratos gratuitos atípicos serão sempre "interessados", pois caso sejam "liberais", entrarão na esfera da doação. Para GALGANO, a liberalidade distingue-se da simples gratuidade em razão da natureza não patrimonial do interesse do praticante do ato, cf. F. GALGAno, Il negozio giuridico, in A. CICU - F. MESSINEO - L. MENGONI (org.), Trattato di diritto civile e commerciale III-I, Milano, Giuffrè, 1988, p. 93.

${ }^{699}$ Cf. C. MANZINI, "Spirito di liberalità" e controllo giudiziario sull'esistenza della causa donandi cit., pp. 419-22. 
De acordo com a segunda, defendida por CAREDDA, para que se exclua a qualificação de um negócio como doação, o interesse econômico deve resultar do ato com certa objetividade - ou através de uma cláusula específica, ou através da coligação negocial $^{700}$, ou ainda através da utilização de variados instrumentos interpretativos, incluída a boa-fé. Se, contudo, não se identifica positivamente um interesse econômico, ainda que não fique explícito um interesse extrapatrimonial específico, o negócio deve ser qualificado como liberalidade, pois isso emerge objetivamente da atribuição feita sem contrapartida $^{701}$.

A nova concepção não é isenta de críticas. Para BozZI, a teoria apresenta uma dificuldade "prático-empírica" e uma dificuldade "dogmático-conceitual". A primeira relaciona-se ao argumento de que estabelecer a natureza patrimonial ou não de um interesse fora dos "casi di scuola" seria praticamente impossível e levaria um retorno à já ultrapassada busca pelos motivos que levaram o doador a praticar o ato ${ }^{702}$.

Não parece, contudo, que a crítica seja pertinente. Por um lado, a própria lei dá relevância aos motivos determinantes em determinadas circunstâncias (arts. 787 e 788 do CC italiano, por exemplo; arts. 166, III, e 140 do CC brasileiro), o que significa que impõe ao intérprete o dever de identificá-los em uma maneira objetiva. Por outro lado, parecem mais do que razoáveis os critérios apontados por CAREDDA para a objetiva identificação de tais interesses, sem que padeçam de excessivo subjetivismo ${ }^{703}$.

${ }^{700}$ DI BIASI, com relação à qualificação das operações negociais complexas como onerosas ou gratuitas, salienta que se deve levar em consideração o inteiro complexo das prestações que derivam dos diversos "frammenti collegati" e ser feita uma "complessiva valutazione di tutti gli interessi coinvolti", ao invés de uma "qualificazione atomistica dei singoli contratti collegati”, cf. A. DI BIASE, Onerosità e gratuità delle operazioni negoziali complesse, Napoli, ESI, 2010, pp. 267-68. No mesmo sentido, cf. P. MOROZZO DELLA ROCCA, Gratuità, liberalità e solidarietà cit., p. 20.

${ }^{701}$ Cf. V. CAREDDA, Le liberalità diverse dalla donazione cit., pp. 37-38. A questão da identificação da presença ou não do interesse econômico não é simples, pois muitas vezes não se dá em termos de alternativa. Segundo Morozzo DELlA RoCCA, trata-se essencialmente de verificar em que sistuações se pode falar em um interesse econômico que integra a causa concreta, e em quais situações o interesse econômico, embora existente, deva ser considerado irrelevante, cf. P. MOROZZO DELLA ROCCA, Gratuità, liberalità e solidarietà cit., pp. 71-72.

${ }^{702}$ Cf. L BOZZI, Alla ricerca del contratto gratuito atipico cit., p. 231.

${ }^{703}$ Não se trata de identificar exatamente qual é o motivo que levou o doador a doar, como a busca pelo afeto ou o desejo de aparecer como uma pessoa generosa no seio da comunidade, mas de estabelecer objetivamente se o interesse do doador consiste ou não em vantagens patrimoniais (ainda que não se configurem juridicamente como contraprestação), cf. P. MOROZZO DELLA RoCCA, Gratuità, liberalità e solidarietà cit., pp. 70-71. 
FERRI aponta, aliás, que essa concepção que identifica o espírito de liberalidade com os interesses nada mais é do que uma manifestação da causa concreta, pois aqueles interesses ou motivos, uma vez reputados determinantes, passarão a integrar o regulamento negocial e a qualificar, em um modo objetivo, o seu elemento funcional (função econômico-individual), passando a integrar a sua causa. Em outras palavras, não se trata de dar relevância a simples motivos subjetivos, pois uma vez integrados na causa, passam a qualificar objetivamente o elemento funcional do negócio ${ }^{704}$. Trata-se da perspectiva de usar a causa concreta como critério para distinguir as zonas cinzentas entre os tipos e identificar em que medida a presença de certos interesses leva à descaracterização do negócio como doação.

A segunda crítica de BOzZI, “dogmático-conceitual”, aponta para o retorno a uma concepção restrita de autonomia privada. Para a autora, enquanto nem a forma nem a patrimonialidade dos interesses deveriam ser necessários para justificar a doação, em razão da consagração da autonomia privada, a nova teoria seria apenas uma maneira de dar nova roupagem à ideia de causa de juridicidade, pois caso o sujeito persiga interesses extrapartimoniais, a forma continua sendo necessária. Nas suas palavras, "la patrimonialità dell'interesse è necessaria per giustificare causalmente una prestazione gratuita laddove non soccorre a tal fine la forma"705.

Essa segunda crítica também não procede. A forma solene para a doação é a exigência legislativa (art. 782), de maneira que não há como se escapar totalmente a ela. Ao contrário do que afirma a autora, a nova concepção favorece a autonomia privada. Ao retirar do âmbito da doação aqueles negócios praticados com interesse patrimonial, a sua prática é simplificada e favorecida, pois escapa à disciplina severa da doação, inclusive no que se refere à forma solene $\mathrm{e}^{706}$.

81.

${ }^{704}$ Cf. G. B. FERRI, Dall'intento liberale al cosiddetto impegno etico e superetico cit., pp. 80-

${ }^{705}$ Cf. L BozzI, Alla ricerca del contratto gratuito atipico cit., p. 231.

${ }^{706}$ Pondera-se que é injustificado submeter um ato inserido na lógica do mercado à exigência da forma solene, ante a exigência de celeridade na circulação de riquezas típica da economia capitalista moderna. Ademais, não se compreende porque um ato inserido no mercado deve submeter o beneficiário ao poder de revogação do doador por ingratidão, cf. P. MOROzzo DELla ROCCA, Gratuità, liberalità e solidarietà cit., p. 62. 


\section{Espírito de liberalidade e espírito de solidariedade}

Ao se falar na nova concepção do animus donandi, falou-se na dicotomia entre interesses patrimoniais ou econômicos e extrapatrimoniais ou não econômicos. Pode-se, todavia, identificar uma terceira categoria de interesses que podem estar envolvidos na doação e nos atos gratuitos em geral.

Segundo FERRI, pode-se fazer uma summa divisio entre duas áreas: a área do gratuito e a área da solidariedade. A diferença está no fato de que liberalidade e gratuidade são principalmente manifestações do exercício da autonomia privada, que podem ser determinadas por variadas razões. Já prestações de solidariedade são sentidas como devidas, pois veiculam a atuação de deveres que recaem sobre o sujeito enquanto se encontre em um estado, permanente ou temporário, de pertencimento a um núcleo social, grande ou pequeno ${ }^{707}$.

Parecem, em princípio, tratar-se de deveres morais ou sociais, mas a Constituição italiana, no art. $2^{\circ}$, fala no adimplemento de deveres inderrogáveis de solidariedade política, econômica e social: "La Repubblica riconosce e garantisce i diritti inviolabili dell'uomo, sia come singolo sia nelle formazioni sociali ove si svolge la sua personalità, e richiede l'adempimento dei doveri inderogabili di solidarietà politica, economica e sociale״708. Segundo RODOTÀ, a consagração do princípio da solidariedade constitucional faz com que os deveres e obrigações dele decorrentes não possam mais ser considerados de natureza exclusivamente extrajurídica, mas o alcance da sua dimensão jurídica ainda é discutível ${ }^{709}$.

06.

${ }^{707}$ Cf. G. B. FERRI, Dall'intento liberale al cosidetto impegno etico e superetico cit., pp. 105-

${ }^{708}$ A Constituição brasileira, logo em seu art. $3^{\circ}$, I, também coloca como um dos "objetivos fundamentais da República" a construção "de uma sociedade livre, justa e solidária". Além disso, insere as "entidades beneficentes e de assisência social" nas "ações governamentais" voltadas para essa área (art. 204, I). IRELLI, em relação ao direito italiano, aponta que a regra da Constituição italiana exprime a ideia de que a realização de atividades de interesse geral não é atribuição exclusiva do Poder Público, mas deve ser exercida também pelos cidadãos. Durante um longo período de expansão do Estado (150 anos) houve uma tendência de estatizar organizações privadas de assistência e beneficência (Estado " 'fagocitò' la rete di assistenza già esistente"). A partir dos anos 80 , iniciou-se um movimento inverso de privatização das organizações públicas, cf. V. C. IRELLI, Gratuità e sussidiarietà tra pubblico e privato, in A. GALASSO - S. MAZZARESE (org.), Il principio di gratuità cit., pp. 469-70.

${ }^{709}$ Cf. S. RODOTÀ, La vita e le regole cit., pp. 122-23. Pode-se falar em uma solidariedade vertical, exercida pelo Welfare State por meio dos seus programas sociais, e em uma solidariedade 
A distinção entre gratuidade e solidariedade é no plano dos interesses, e não dos instrumentos jurídicos previstos no ordenamento. As partes, na sua concreta atuação, podem utilizar para veiculá-los tanto instrumentos jurídicos ligados à área da gratuidade como o contrato de doação e outros contratos gratuitos - quanto instrumentos ligados ao mercado - contratos onerosos ${ }^{710}$.

A ideia da solidariedade, em princípio, lembra uma reconstrução, por GALASSO, da gratuidade como um princípio, que seria "regulador do contato social" e "fundamento da eficácia jurídica" (da atuação em concreto) de interesses insuscetíveis de avaliação econômica pelo mercado ${ }^{711}$. Segundo RODOTÀ, todavia, a solidariedade abrange uma área bem mais ampla que a gratuidade, que tem uma incidência circunscrita e limitada a determinadas categorias de relações jurídicas. Não tem, portanto, a característica de um princípio geral, ao contrário da solidariedade, que pode se inserir inclusive em relações comerciais $^{712}$.

Especificamente com relação à doação, LIPARI contrapõe um "espírito de liberalidade" e um "espírito de solidariedade" - enquanto o primeiro seria pautado pela espontaneidade, o segundo decorreria de um dever de solidariedade constitucionalmente previsto, que deve ser entendido como um princípio geral, uma chave de leitura de todo o ordenamento. Na medida em que aparece a solidariedade como uma valorização abrangente das exigências das partes envolvidas, reduz-se a ideia de um altruísmo visto individualmente e como um fim em si mesmo, destacado de outras exigências e relações. A solidariedade estaria relacionada a interesses que transcendem aqueles das partes contratantes, se pensarmos no modelo formal do contrato ${ }^{713}$.

horizontal, que rege a relação entre os privados, cf. P. MOROZzO DELLA ROCCA, Gratuità, liberalità e solidarietà cit., pp. 122-25. 06.

${ }^{710}$ Cf. G. B. FERRI, Dall'intento liberale al cosidetto impegno etico e superetico cit., pp. 105-

${ }^{711}$ Cf. A. Galasso, Principio di gratuità cit., pp. 214-16.

${ }^{712}$ Cf. S. RODOTÀ, La vita e le regole cit., pp. 120-21.

${ }^{713}$ Cf. N. LIPARI, "Spirito di liberalità" e "spirito di soliderietà" cit., pp. 8-10, 13-14 e 16. Em um interessante ensaio, RODOTÀ traça o percurso histórico e fala da relevância atual do princípio da solidariedade. O princípio não é tão recente - da tríade revolucionária francesa ("liberdade, igualdade e fraternidade"), a solidariedade ligar-se a esta última. Nos dias atuais, porém, enfrenta novas questões. Por um lado, com a "diminuição" do tamanho do Estado, a solidariedade ganha incentivo, na medida em que se buscaria atribuir aos privados funções públicas assistenciais que antes eram do Estado. Por outro lado, na Europa atual, em que a discussão sobre os influxos migratórios ganha corpo, haveria um movimento contrário à generalização da solidariedade, na medida em que surgem posições que defendem até mesmo a 
Tradicionalmente, a esfera da autonomia privada comportaria majoritariamente os atos que requerem uma contrapartida patrimonial, apenas tolerando - e não valorizando - a doação ${ }^{714}$. Na medida em que há um reconhecimento da solidariedade como valor jurídico-constitucional, esse quadro começa a mudar, pois começam a se introduzir sanções positivas facultativas, principalmente para atos e atividades organizadas em torno de determinados cânones ${ }^{715}$.

Uma nítida repercussão disso é tributária. Para Morozzo DELla RocCA, é natural que o legislador tributário, justamente tendo em conta aquela função promocional do Estado, tribute tais atos de maneira diferente da doação que exprime interesses puramente privados $^{716}$. Para se fazer um paralelo com o direito brasileiro, no Estado de São Paulo, o art. $6^{\circ}, \S 2^{\circ}$ da Lei Estadual 10.705, de 28 de dezembro de 2000 traz uma isenção para a cobrança de ITCMD “as transmissões 'causa mortis' e sobre doação de quaisquer bens ou direitos a entidades cujos objetivos sociais sejam vinculados à promoção dos direitos humanos, da cultura ou à preservação do meio ambiente" ${ }^{\text {,717 }}$. Outro exemplo de favorecimento às doações está no disposto no art. 80 dos ADCT, que estimula a realização de "doações, de qualquer natureza, de pessoas físicas ou jurídicas do País ou do exterior" para compor o Fundo de Combate e Erradicação da Pobreza.

punição de cidadãos europeus que prestam ajuda ou fornecem trabalho a imigrantes ilegais, cf. S. RODOTÀ, Solidarietà - Un'utopia necessaria, Roma, Laterza, 2014, passim e pp. 3- 21, principalmente.

${ }^{714}$ Cf. I.7.3.

${ }^{715}$ Cf. P. Morozzo della Rocca, Gratuità, liberalità e solidarietà cit., p. 145. Segundo RESCIGNO, embora haja uma nítida aproximação entre as liberalidades inter vivos e as disposições testamentárias, não pode haver uma transposição absoluta dos critérios de interpretação do testamento para as liberalidades, justamente porque, no caso destas últimas, a interpretação deve ser orientada e desenvolvida na perspectiva da solidariedade individual e social, cf. P. RESCIGNO, Note sull'interpretazione degli atti di liberalità, in Vita notarile 50 (1998), pp. 61-62.

${ }_{716}$ Cf. P. MOROZzo DELLA RocCA, Gratuità, liberalità e solidarietà cit., pp. 191-192.

${ }^{717}$ Exige-se o reconhecimento "de forma cumulativa, pela Secretaria da Fazenda e, conforme a natureza da entidade, pela Secretaria da Justiça e da Defesa da Cidadania, pela Secretaria da Cultura ou pela Secretaria do Meio Ambiente, de acordo com disciplina a ser estabelecida pelo Poder Executivo", além da observação dos requisitos "previstos na legislação tributária". Entre estes, ressalta-se que o art. $9^{\circ}$, IV, do CTN veda à União, aos Estados, ao Distrito Federal e aos Municípios cobrar imposto sobre "o patrimônio, a renda ou serviços dos partidos políticos, inclusive suas fundações, das entidades sindicais dos trabalhadores, das instituições de educação e de assistência social, sem fins lucrativos". Além disso, tais entidades devem abster-se de distribuir "qualquer parcela de seu patrimônio ou de suas rendas, a qualquer título", aplicar "integralmente, no País, os seus recursos na manutenção dos seus objetivos institucionais" e manter "escrituração de suas receitas e despesas em livros revestidos de formalidades capazes de assegurar sua exatidão" (art, 14, I, II e III). Por fim, o $§ 2^{\circ}$ do art. 14 esclarece que tais "serviços" são "exclusivamente, os diretamente relacionados com os objetivos institucionais das entidades" e "previstos nos respectivos estatutos ou atos constitutivos". 
Em face desse quadro, a doutrina na Itália discute como tais interesses ligados à solidariedade devem repercutir nos instrumentos da chamada "velha gratuidade", como o contrato de doação, pois este, em princípio, seria uma forma de disposição dos bens por interesses particulares - ainda que de natureza não patrimonial - que não apresenta um interesse público evidente consistente no escopo de solidariedade ${ }^{718}$.

Para uma corrente, a solidariedade social não pode vista como mero motivo irrelevante que levou o agente a praticar o ato ${ }^{719}$, mas deve integrar a causa concreta, o que permite um controle objetivo acerca dos interesses veiculados no negócio individualmente celebrado entre as partes e os valores do ordenamento. Na medida em que estaria situada entre os interesses patrimoniais e extrapatrimoniais ${ }^{720}$, poderia servir para atenuar a disciplina severa reservada à doação, até mesmo permitindo a sua construção como um tipo autônomo ${ }^{721}$.

\section{Doação e deveres jurídicos e extrajurídicos}

Um tema conexo ao tratado no tópico anterior é o problema da existência de deveres extrajurídicos em cumprimento dos quais as pessoas praticam atribuições sem contrapartida. Segundo BIONDI, a doação, em qualquer concepção, passada e presente, doutrinária ou positiva, é sem dúvida um ato de liberalidade. Liberalidade (liberalitas) é uma ideia que se contrapõe à necessidade (necessitas) e, mais do que generosidade, denota a ideia de plena liberdade. Por isso, não se poderia falar de liberalidade no caso do

${ }^{718}$ Cf. P. MoROzzo DElla RoCCA, Gratuità, liberalità e solidarietà cit., pp. 128 e 191-192. Embora a Constituição italiana fale em “dever", deve-se considerar que abandonou uma visão simplesmente coativa em prol de uma visão promocional da solidariedade.

${ }^{719}$ Cf. N. LIPARI, "Spirito di liberalità" e "spirito di soliderietà ” cit., pp. 8-10, 13-14 e 16.

${ }^{720}$ Cf. P. MOROZzo DELla RoCCA, Gratuità, liberalità e solidarietà cit., pp. 191-192.

${ }^{721}$ Como visto, algo parecido consolidou-se na França através do uso de uma concepção subjetiva de animus donandi, que fez com que a presença de determinados interesses excluísse a caracterização do ato como doação, e, como consequência, afastando a exigência da forma solene, cf. III.3.1. Segundo PELLEGRINI, o reconhecimento da solidariedade no plano constitucional permitiria a construção de uma categoria negocial típica autônoma com função econômico-social diversa da doação e que, portanto, não estaria sujeita à sua disciplina. Seria uma causa de solidariedade distinta da liberalidade. Embora diga respeito a interesses extrapatrimoniais (os quais, para uma corrente, servem para caracterizar as liberalidades), apresentaria um "quid ulteriore", o que permitiria ver uma categoria completamente autônoma. $\mathrm{O}$ autor pondera, todavia, que talvez seja necessária a intervenção do legislador para viabilizar esse reconhecimento, cf. L. PELLEGRINI, La donazione costitutiva di obbligazione cit., pp. 212-18. 
adimplemento de uma obrigação, entendida em sentido amplo, a ponto de compreender as obrigações naturais $^{722}$.

Em 1947 vinha à tona a obra de OPPO, Adempimento e liberalità, na qual o jurista identificou que entre os extremos do adimplemento de uma obrigação jurídica e a liberalidade existem hipóteses intermediárias difíceis de qualificar, que pendem para um ou outro lado, pois podem apresentar características de ambos. Entre um dever jurídico e a ausência completa de um dever, existem deveres não jurídicos juridicamente relevantes ${ }^{723}$.

Esses deveres têm origem em relações sociais governadas por normas diversas das normas jurídicas - como normas morais - a que o direito atribui relevância jurídica, traduzida em efeitos jurídicos, mas diferentes da natureza obrigacional. Em princípio, normas não jurídicas são indiferentes e irrelevantes para o direito. Excepcionalmente, porém, pode haver uma parcial relevância, sem que haja uma confusão entre os ordenamentos jurídico e extrajurídico. Este atribui relevância jurídica - e efeitos jurídicos - a preceitos dos ordenamentos extrajurídicos sem destruir a sua autonomia enquanto pertencentes a um ordenamento diverso ${ }^{724}$.

A norma extrajurídica não é levada em consideração como reguladora da relação extrajurídica, mas enquanto fattispecie, um mero pressuposto de fato, como qualquer outro, para a produção de efeitos jurídicos que não coincidem com aqueles prescritos pela norma extrajurídica; caso contrário, poder-se-ia falar em recepção ou atribuição de juridicidade a essa norma ${ }^{725}$.

Subjacente a essa discussão está a relação entre doação e obrigação natural. A preocupação tem particular relevância no direito brasileiro em razão do disposto no art. 564, III, do nosso CC: "Não se revogam por ingratidão" as doações "que se fizerem em cumprimento de obrigação natural". Se a doação se caracteriza pela espontaneidade, o que exclui a presença de um dever qualquer, ainda que consistente em uma obrigação natural, como afirma BIONDI, então o dispositivo parece encerrar uma contradição em termos.

\footnotetext{
${ }^{722}$ Cf. B. BIONDI, Donazione (diritto civile), in NNDI 6 (1960), p. 235.

${ }^{723}$ Cf. G. OPPO, Adempimento e liberalità cit., pp. 5-6.

${ }^{724}$ Cf. G. OPPO, Adempimento e liberalità cit., pp. 6-11.

${ }^{725}$ Cf. G. OPPO, Adempimento e liberalità cit., pp. 15-16.
} 
A noção de obrigação natural é controversa, pois sua definição implica uma escolha precisa entre duas tendências doutrinárias - uma que reconduz a obrigação ao âmbito das obrigações jurídicas, e outra que a considera como expressão de exigências morais que têm uma limitada relevância para o direito ${ }^{726}$.

Conforme afirma ANTUNES VARELA, a obrigação natural pode ser entendida tanto como uma obrigação jurídica imperfeita e judicialmente inexigível, quanto como um dever moral e social juridicamente relevante ${ }^{727}$. O autor pende para a segunda concepção, expressamente adotada no art. $402^{\circ}$ do CC português, que dispõe: "a obrigação diz-se natural, quando se funda num mero dever de ordem moral ou social, cujo cumprimento não é judicialmente exigível, mas corresponde a um dever de justiça”.

$\mathrm{O}$ art. 2.034 do CC italiano também implica uma precisa escolha do legislador de 1942, a de que a obrigação natural não é uma obrigação jurídica, mas meramente moral ou social ${ }^{728}$. O dispositivo estabelece que não é admitida a repetição daquilo que foi espontaneamente prestado em cumprimento a deveres morais ou sociais - "non è ammessa la ripetizione di quanto è stato spontaneamente prestato in esecuzione di doveri morali o sociali" - e acrescenta que tais deveres "non producono altri effetti",729.

794.

${ }^{726}$ Cf. C. M. BiancA, Diritto civile IV-L'obbligazione, Milano, Giuffrè, 1990, pp. 777-84 e

${ }^{727}$ Cf. J. M. ANTUNES VARELA, Das obrigações em geral I cit., pp. 738-41. ANTUNES VARELA menciona ainda uma terceira concepção, que atribui a CARNELUTTI, da "obrigação natural como pura situação de fato".

${ }^{728}$ Cf. C. M. BIANCA, Diritto civile IV cit., pp. 777-84.

${ }^{729}$ FERRAZ Jr., destaca que "o jurista se vê às voltas, na estrutura social, com uma multiplicidade" de normas, "dentre as quais estão aquelas que lhe interessam particularmente: as jurídicas". O problema é que essas normas "podem não ser compatíveis umas com as outras", e "as estruturas sociais em geral manifestam mais normas que a sociedade pode suportar", cf. T. S. FERRAZ Jr., Introdução ao estudo do direito cit., pp. 105-06. REALE destaca que "são muitas as teorias sobre as relações entre o Direito e a Moral", cf. M. REALE, Lições preliminares de direito, $27^{\mathrm{a}}$ ed., 15 ${ }^{\mathrm{a}}$ reimpr. (2015), São Paulo, Saraiva, 2002 , p. 41. Segundo MENEZES CORDEIRO, o "critério último de distinção", "em termos latos", entre o direito e "as demais ordens jurídicas" é a "positividade", no sentido de que o direito "exprime as regras que, dogmaticamente elaboradas, podem aplicar-se a litígios sociais, através de instituições para tanto preparadas". Segundo o autor, "o sistema compreende as suas próprias normas de reconhecimento que o habilitam, em cada momento histórico, a detectar as proposições que lhe pertencem". As demais normas, as extrajurídicas, têm o condão de "valorar as condutas humanas", mas "se ficam por aí: falta-lhes a capacidade especial de realização, na comunidade, de que desfruta a positividade jurídica”, cf. A. M. R. MENEZES CORDEIRO, Da boa fé no direito civil cit., pp. 1167-68. Segundo BIANCA, haveria dever moral ou social caracterizador da obrigação natural (segundo uma das vertentes) - quando a prática do ato é moralmente ou socialmente necessária em razão da consciência social ou coletiva. Não basta que o ato seja valorado positivamente, mas é necessário que sua inobservância comporte um juízo de reprovação ou desestima. No âmbito dos deveres sociais, o dever moral distingue-se em razão de uma cogência mais intensa e superior, como expressão da ética social. O descumprimento de deveres sociais não atenta contra a moral, mas acarreta 
No Brasil, por outro lado, parece ter prevalecido a tendência que descola a obrigação natural dos referidos deveres. Embora COUTO E SILVA tenha afirmado que foi adotado um conceito genérico, que incluía "os deveres morais que tradicionalmente se conumeram entre as hipóteses daquele tipo de obrigações" "730, a lei brasileira não traz nenhuma vinculação expressa entre a obrigação natural e deveres morais e sociais. O CC de 1916, ao regular o pagamento indevido, afirmava simplesmente que não se pode repetir o que se pagou para solver "obrigação natural" (art. 970), sem fazer nenhuma referência àqueles deveres.

O novo CC buscou escapar a qualquer polêmica quanto ao conceito, substituindo a expressão obrigação natural por "obrigação judicialmente inexigível" no atual art. 882. GOMES, por exemplo, trata as obrigações naturais propriamente ditas e os deveres morais e sociais como espécies distintas de obrigações imperfeitas. Enquanto as primeiras "possuem todos os caracteres de um dever jurídico", as segundas "existem à margem da 'zona do juridicamente coercível",731.

É a partir dessa separação que PONTES DE MIRANDA esclarece o sentido do antigo art. 1.187, III (atual art. 564, III). Para esse autor, as obrigações naturais são dívidas jurídicas. O que não existe é a pretensão e a ação, e é por isso que "quem solve não doa, paga", pois "o que se presta para se cumprir obrigação natural não é doação, é pagamento" 732 .

uma estima social negativa, como no caso do descumprimento de dívidas de jogo e aposta, cf. Cf. C. M. BIANCA, Diritto civile IV cit., pp. 778-80.

${ }^{730}$ Cf. C. V. CoUto E SiLva, A obrigação como processo cit., p. 89.

${ }^{731}$ Cf. O. GOMES - E. BRITO, Obrigações cit., pp. 96-97.

${ }^{732}$ Cf. F. C. PONTES DE MIRANDA, Tratado de direito privado XLVI cit., pp. 231-32 e 278-80. BIANCA faz muitas críticas à concepção de obrigação natural como uma obrigação jurídica, tanto na vertente que a enxerga como um débito sem responsabilidade - isto é, com um conteúdo patrimonial não garantido pelo patrimônio do devedor -, quanto na que a vê como uma obrigação jurídica imperfeita, cf. C. M. BIANCA, Diritto civile $I V$ cit., pp. 27-28 e 783-84. A primeria teoria não teria amparo legal no CC italiano, que não permite ver o débito e a responsabilidade como posições distintas e separáveis (com a possibilidade de subsistirem o débito sem responsabilidade e a responsabilidade sem o débito), uma vez que a doutrina prevalente vê a responsabilidade patrimonial como instrumento apenas acessório de garantia do crédito. Além disso, a falta de responsabilidade patrimonial do devedor seria justamente a expressão da ausência de sanção que caracteriza os deveres não jurídicos. A segunda visão tampouco seria aceitável, pois o único efeito previsto pelo $\mathrm{CC}$, a não repetibilidade, não seria suficiente para se entender que se trata de obrigação jurídica imperfeita, porque não acionável, mas apesar disso sujeita à disciplina das obrigações jurídicas. BIANCA também considera artificial a tese de CARNELUTTI de que a obrigação natural adquire relevância como obrigação jurídica no momento do seu adimplemento. Seria ilógico dar ex post caráter de juridicidade necessária a uma prestação que, pela lei, o sujeito é livre para cumprir ou não. 
O jurista esclarece que a dificuldade interpretativa surgiu na tramitação do projeto que deu origem ao $\mathrm{CC}$ de 1916. O art. 1.327 do projeto primitivo dispunha que não estavam sujeitas a revogação por ingratidão as doações que fossem "realizadas em satisfação de um dever moral". Foi no projeto definitivo, art. 1.350, que a referência a “dever moral” foi substituída por "obrigação natural”. Assim, a interpretação mais acertada seria no sentido de se entender aplicável a regra da impossibilidade de revogação por ingratidão às doações efetuadas em atenção a um dever moral ${ }^{733}$.

Recentemente, o STJ defrontou-se com um caso bastante interessante. Trata-se do REsp 1.371.842 ${ }^{734}$, que teve origem em uma "ação de revogação de doação com restituição de valores" consistentes em "dízimos e outras contribuições". O autor da demanda era fiel de uma igreja que frequentou durante quase sete anos, destinando à instituição contribuições que totalizaram, aproximadamente, trinta e quatro mil reais. $\mathrm{O}$ pastor o teria ofendido chamando-o "diabo, invejoso e vagabundo", em virtude de suposto artigo publicado na internet denominado "Pastor do Milhão", cuja autoria teria sido erroneamente imputada ao autor. Pleiteou, assim, a revogação da doação por ingratidão, com base no art. 557, III, do CC br.

A demanda foi julgada improcedente em primeiro grau. O TJ de origem negou provimento ao recurso de apelação do autor, sob argumento de que os pagamentos se deram "em cumprimento de preceito religioso", como prova "de sua fé e aceitação dos mandamentos de sua igreja", indo "muito além de meras doações, feitos por liberalidade ou gratidão".

Na mesma esteira, a Terceira Turma do STJ negou provimento ao recurso especial. Afirmou-se que enquanto "ato de voluntariedade fundado no dever de consciência religiosa e demonstração de gratidão e fé", as contribuições não exprimem "o desejo do doador de que a vantagem implique em (sic) enriquecimento do donatário".

O relator Min. Sidnei Beneti, aliás, destacou que são possíveis dois conceitos de doação - um lato, que abrange qualquer "liberalidade", e um restrito, disciplinado no CC a partir do art. 538. A doação em "cumprimento de um dever de consciência” seria

\footnotetext{
${ }^{733}$ Cf. F. C. PONTES DE MIRANDA, Tratado de direito privado XLVI cit., pp. 278-80.

${ }^{734}$ Cf. STJ, $3^{\mathrm{a}}$ Turma, REsp 1.371.842-SP, Rel. Min. Sidnei Beneti, j. 19.11.2013.
} 
doação apenas em seu sentido lato, não se lhe aplicando as regras da segunda espécie, uma vez que não há pura espontaneidade.

Não restam dúvidas de que a existência de um dever jurídico leve à descaracterização de um negócio como doação. O problema, como já apontava OPPO, diz respeito a deveres não jurídicos, como o referido "dever de consciência", ao qual o STJ nitidamente atribuiu relevância jurídica a ponto de descaracterizar um instituto jurídico regulado pela lei. Trata-se, em última análise, justamente do problema da coexistência de normas jurídicas com normas extrajurídicas.

Em sua obra, OPPO preocupou-se com o suporte fático, a qualificação e a disciplina das liberalidades de uso, da doação remuneratória e do adimplemento de obrigação natural, em sua relação, de um lado, com o adimplemento da obrigação civil, e, de outro, com as liberalidades e a doação ${ }^{735}$.

As liberalidades em conformidade aos usos são definidas no art. 770, 2, do CC italiano, que prevê: "Non costituisce donazione la liberalità che si suole fare in occasione di servizi resi, o comunque in conformità agli usi”. Nessas figuras estariam presentes todos os elementos característicos da doação, mas haveria um elemento a mais - a conformidade com uma norma costumeira que faz com que o ato se apresente como devido ${ }^{736}$.

${ }^{735} \mathrm{G}$. OPPO, La prestazione in adempimento di un dovere non giuridico (cinquant'anni dopo), in Riv. dir. civ. 43 (1997), pp. 515 e 523-24.

${ }^{736}$ As liberalidades de uso seriam aquelas relacionadas e praticadas em cumprimento ao “costume social”, cf. L. Pellegrini, La donazione costitutiva di obbligazione cit., p. 74. Para OPPO, justamente por isso, essas liberalidades não acarretariam o problema de distinção com relação às obrigações naturais, pois não são atos praticados em razão de deveres morais ou sociais, cf. G. OPPO, Adempimento e liberalità cit., pp. 88-89 e 97-105. PONTES DE MIRANDA, por sua vez, não faz distinção entre deveres morais e sociais de um lado, e costumes sociais do outro, mas considera os deveres sociais como equivalentes aos costumes sociais, distinguindo-se por sua vez, dos deveres morais. Trata-se do "dever de decoro ou cerimônia", como o de dar "presentes usuais", em que o "elemento de pressão interior", nesses casos, fica fora da "vinculação moral", cf. PONTES DE MIRANDA, Tratado de direito privado XLVI cit., pp. 241 e 278-81. REALE, amparado em DEL VECCHIO e RADBRUCH, faz uma tripartição entre direito, moral e costume. Define costume como aquelas "normas de trato social, que vão desde as regras mais elementares do decoro às mais refinadas formas de etiqueta e de cortesia". Essas normas ocupariam "uma situação intermediária entre a Moral e o Direito", cf. M. REALE, Lições preliminares de direito cit., pp. 56-57. Não se deve confundir, entretanto, esses costumes sociais com usos e costumes jurídicos, que são propriamente fonte do direito (direito costumeiro ou consuetudinário), que apresenta grande força "em certos ramos ou para a solução de determinados problemas, como é o caso do Direito Comercial e do Direito Internacional", cf. M. REALE, Liçoes preliminares de direito cit., pp. 159-60. Os costumes, ademais, são expressamente definidos como mecanismo de integração do direito pela LINDB (art. $4^{\circ}$ ) e têm particular relevância em diversos dispositivos do CC brasileiro. Com relação às liberalidades de uso no direito italiano, para Morozzo DELLA RocCA, abrangeriam uma gama heterogênea de figuras, desde negócios juridicamente vinculantes até uma "serie 
Isso levou o CC italiano a excluir esses atos do âmbito da doação, mas, na realidade, o efeito será somente a parcial exclusão de algumas normas da sua disciplina jurídica - como a exigência de forma solene e as normas protetivas aos direitos dos herdeiros. Segundo OpPO, essas regras já seriam desnecessárias, na medida em que as liberalidades em conformidade com os usos são módicas por natureza, não sendo passíveis de acarretar prejuízo a prestador e aos herdeiros. Caso contrário, não se estaria efetivamente diante de uma liberalidade em conformidade aos usos, mas de verdadeira doação ${ }^{737}$.

No direito brasileiro, há quem exclua tais prestações do âmbito da doação, e há quem as inclua no âmbito das doações manuais. PEREIRA, por exemplo, afirma que "não se inscrevem" como doação, não se lhes aplicando as normas legais, "certas atribuições gratuitas que se costumam fazer por ocasião de serviços prestados (gorjetas, gratificações),

vastissima di piccole attribuzioni che paiono conferire meri atti di cortesia o di "urbanità"'. Poderiam ser diferenciados os atos de cortesia dos atos de amizade. Os primeiros apresentariam traços objetivos que "empobrecem" a figura, tornando-a inidônea à juridificação. Os segundos mimetizariam a estrutura contratual, mas em um plano externo ao direito. Especificamente com relação aos negócios de cortesia, a discussão diz respeito ao problema mais complexo sobre atos e prestações que não criam vínculos jurídicos, cf. P. MOROZZO DELlA RoCCA, Gratuità, liberalità e solidarietà cit., pp. 98-99 e 117-18. A dúvida é se basta o reconhecimento social (ou as circunstâncias negociais, na terminologia de JUNQUEIRA DE AZEVEDO) para que o negócio praticado pelas partes atraia automaticamente a regulação jurídica, ou se é necessário um "intento giuridico positivo" das partes para que voluntariamente se atribua juridicidade ao vínculo. Outra questão é se a vontade das partes ("intento giuridico negativo") poderia voluntariamente excluir a incidência das regras do direito, cf. P. MOROZZO DELlA RoCCA, Gratuità, liberalità e solidarietà cit., pp. 98-99 e 11718. Segundo PELlEGRINI, a posição dominante é no sentido de que os acordos de cortesia distinguem-se da doação pelo valor da prestação, pela inidoneidade a produzir affidamento na outra parte e, principalmente, pela falta de um intento de os sujeitos se obrigarem juridicamente. Haverá um acordo negocial, assim, se as partes manifestarem a intenção de se vincular, e se estará diante de um acordo de cortesia quando as partes expressamente excluírem a obrigatoriedade jurídica do negócio. Um argumento contrário ao "intento giuridico negativo" consiste no temor de que seja possível às partes subtrair determinadas relações à incidência de normas jurídicas cogentes de ordem pública. Esta posição, todavia, seria minoritária, cf. L. PELLEGRINI, La donazione costitutiva di obbligazione cit., pp. 161-63.

${ }^{737}$ Cf. G. OPPO, Adempimento e liberalità cit., pp. 88-89 e 97-105. Outro problema tratado por OPPO é o da doação remuneratória, que no art. 770, 1, do CC italiano é definida amplamente como "la liberalità fatta per riconoscenza o in considerazione dei meriti del donatario o per speciale rimunerazione". Como visto, a ideia de obrigação natural naquele país está ligada ao cumprimento de deveres morais ou sociais (art. 2.034), o que gera dúvida sobre como distinguir ambas as figuras. Com relação à doação remuneratória, a conclusão de OPPO é no sentido de que é feita sim em cumprimento a um dever moral de gratidão ou reconhecimento, o que normalmente atrairia a categoria da obrigação natural. Por ser um dever mais fraco, todavia, a lei expressamente exclui a doação remuneratória de seu âmbito. Trata-se, como se pode ver, de um caso limite. 
ou no cumprimento de deveres ou desempenho de costumes sociais (esmolas, donativos por ocasião de datas festivas ou cerimônias religiosas)" ${ }^{\text {,738. }}$.

Para PONTES De MirandA, ao contrário, os deveres "de decoro ou cerimônia", como o de "dar presentes usuais" se inseriria no âmbito das doações manuais, afirmando que o juiz, ao avaliar a modicidade no valor, não deve levar em conta somente o elemento econômico, mas a circunstância de se tratar de cumprimento de um dever extrajurídico ${ }^{739}$. PENTEADO, por sua vez, entende que a esmola é doação de bens móveis e de pequeno valor. Já os atos de amizade e cortesia e os presentes não seriam doação, pois não seriam vistos socialmente como negócio jurídico, ou seja, faltariam as circunstâncias negociais ${ }^{740}$.

As questões tratadas neste tópico são bastante complexas, pois tangenciam o problema do limite tênue entre a área do direito e do não direito, e do que é e do que não é negócio jurídico. Nesse sentido, JUNQUEIRA DE AZEVEDO menciona os "atos de favor" ou "negócios de pura obsequiosidade", que não são "reconhecidos socialmente como jurídicos" ${ }^{, 741}$. O estudo dessas questões com maior profundidade foge ao âmbito deste trabalho, mas fica a sugestão para o leitor de que são pontos relevantes que merecem maior atenção por parte dos civilistas brasileiros.

${ }^{738}$ Cf. C. M. S. PereirA - R. FiChtNer, Instituições de direito civil III cit., p. 248. Para RosenVALD, "também se afastam da doação os atos de cortesia, como o gesto de presentear amigos por ocasiões especiais”, cf. N. RosENVALD, Arts. 481 ao 652 - Contratos (em espécie) cit., p. 424.

${ }^{739}$ Cf. F. C. PONTES DE MIRANDA, Tratado de direito privado XLVI cit., pp. 241 e 278-81.

${ }^{740}$ Cf. L. C. PENTEADO, Doação com encargo e causa contratual cit., pp. 307-09 e 342.

${ }^{741}$ Cf. A. JUNQUEIRA DE AZEVEDO, Negócio jurídico e declaração negocial cit., p. 43. 


\section{CONSIDERAÇÕES FINAIS}

As opções e posições dogmáticas sobre os pontos especificamente trabalhados ao longo do texto já foram explicitadas no decorrer do trabalho. O objetivo destas considerações finais é retomar a linha-mestra que guiou a pesquisa, de modo a organizar o raciocínio que inspirou o tratamento da matéria.

$\mathrm{Na}$ realidade de vida, as pessoas praticam atribuições patrimoniais gratuitas e prestam serviços gratuitos. O direito, ao conceituar determinadas condutas como "doação", não descreve simplesmente aquilo que ocorre no mundo (definição léxica), mas seleciona parcela daqueles fatos concretos e constrói um conceito (definição estipulativa) com o objetivo de regulá-los de determinada maneira e em atenção a certos objetivos que acredita ser importantes para a vida em sociedade.

No caso da doação, a ordem jurídica busca favorecer, por um lado, a liberdade individual de cada um dispor sobre seu patrimônio, e por outro, a solidariedade e o altruísmo entre as pessoas. É inegável, todavia, que a cerque de cuidados, o que se deve a um suposto risco de perda patrimonial para o doador e seus herdeiros, e ao temor de que seja praticada para ocultar alguma fraude ou ilícito. Já dizia o provérbio: "Quando a esmola é muita, o santo desconfia".

Para atingir seus objetivos, o direito precisa construir um conceito de doação, isto é, dar-lhe (por meio de regras constitutivas) uma precisa estrutura e um preciso conteúdo que permitam a aplicação de regras jurídicas (regulativas) próprias, que irão estabelecer as condutas que são permitidas, proibidas ou obrigatórias. Vale-se, assim, de categorias de direito privado elaboradas tendo como parâmetro o homo oeconomicus e o ambiente do mercado, que muitas vezes não dão conta de lidar com atribuições patrimoniais sem contrapartida sem alguma dose de distorção.

O exemplo mais notório disso é a noção de contrato. Embora as legislações atuais tendam a atribuir à doação estrutura contratual, isso não se dá (e não se deu, na história) sem dificuldades. A estrutura contratual é criticada, entre outros aspectos, pelo fato de a doação implicar uma "operação econômica unilateral", por ser uma "categoria geral" cujos efeitos podem ser conseguidos através de outros fatos jurídicos (doações 
indiretas ou liberalidades diversas da doação) e pela proximidade de seus efeitos com aqueles produzidos pelo testamento.

E isso se reflete nas diferentes configurações jurídicas que a doação teve e tem, como foi visto. No direito italiano, a doação é contrato, mas é "sui generis" e disciplinado junto ao direito das sucessões. Parece ser um exemplo bastante simbólico dessas dificuldades o fato de Napoleão ter, intuitivamente, determinado a substituição da palavra "contrato" por "ato" na definição que consta do art. 894 do Code civil. Apesar dessas relevantes observações, entretanto, a doação deve efetivamente ser tratada como contrato, não só por ser expressamente definida como tal no art. 538 do CC brasileiro, mas porque é sempre possível identificar interesses do doador na prática da doação, o que caracteriza a contraposição de interesses própria aos contratos.

Outra questão diz respeito ao nível de cautela que o direito pretende ter e ao nível de liberdade que pretende conferir ao doador para regular seus próprios interesses. A doação é um campo, aliás, em que se identifica a manutenção de regras milenares por força da tradição, o que pode levar a uma concepção muitas vezes limitada acerca da autonomia privada. Essa ideia está subjacente à discussão sobre a natureza real ou consensual, e a admissão ou não do contrato preliminar de doação. No fundo a pergunta é: pode o doador ser obrigado a doar?

Embora se reconheça que a questão é bastante polêmica, a resposta não pode deixar de ser afirmativa. A autonomia privada implica a liberdade para contrair obrigações por meio de acordos, e um dos princípios contratuais mais basilares é que os contratos devem ser cumpridos. Ao se obrigar a doar, o doador age no âmbito de sua autonomia privada, e cria para o donatário a legítima expectativa de receber o bem prometido. Entender que tal acordo não é obrigatório - ou só o é se for realizado mediante forma solene, que entraria no lugar de sua causa de juridicidade - implica adotar uma ideia de autonomia privada muito restrita, própria de sistemas como o romano em que os contratos eram típicos, o que talvez não faça mais sentido na sociedade capitalista moderna.

A preocupação do direito é identificar quais são as práticas sociais que merecem estar submetidas às regras regulativas da doação, notadamente aquelas relativas aos requisitos formais (forma solene no direito francês e italiano; forma escrita no direito 
brasileiro), à proteção da legítima dos herdeiros necessários e à possibilidade de revogação. Essa questão se traduz na discussão sobre a inclusão da prestação de serviços gratuitos, ou prestações de fazer e até não fazer, no objeto da doação.

Segundo uma concepção mais tradicional, somente aquelas atribuições que operam um acréscimo duradouro no patrimônio do beneficiário (transmissão ou constituição de direitos sobre a coisa) é que justificariam a aplicação da rígida disciplina da doação. Outra concepção, construída na Itália, entende que os serviços e as prestações de fazer e não fazer adquiriram tamanha relevância na sociedade atual que seria injustificado e anacrônico não submetê-los ao mesmo tratamento da doação.

O problema dessa segunda posição, além de dificuldades práticas consistentes na definição do valor da prestação para aplicação de algumas regras (nulidade da doação inoficiosa, dever de colação etc.), está no fato de que a forma solene (exigida nos direitos francês e italiano) vem sendo ela própria considerada anacrônica na sociedade moderna, além de ser um empecilho à solidariedade social e ao altruísmo consistente na prestação de serviços gratuitos. Parece mais adequado, dessa forma, que o âmbito da doação seja limitado às prestações de dar. Evita-se, assim, baralhar noções concretizadas há tempos na dogmática civilista (distinção entre doação e contratos gratuitos com base na natureza da prestação) e a aplicação de regras excessivamente rigorosas a negócios que não implicam perda patrimonial efetiva para o doador.

Ainda com relação à delimitação do âmbito de incidência das regras regulativas, é necessário saber se a presença de determinados interesses ou determinados deveres levaria a uma desqualificação do negócio como doação. Por um lado, parece que o doador no mais das vezes não age por "pura liberalidade", mas também tem interesses na doação (o que, como dito, confirma a presença daqueles interesses contrapostos que justificam a sua estrutura contratual).

Uma proposta interessante aventada na doutrina italiana das últimas décadas seria entender que a presença comprovada de um interesse econômico do doador (que não consista, obviamente, em uma contraprestação) poderia descaracterizar o negócio, fazendo com que fosse tratado como um contrato gratuito atípico ao qual não se aplicaria a 
disciplina jurídica de forma, proteção aos herdeiros necessários, possibilidade de revogação por ingratidão etc.

Por outro lado, surge a questão acerca da presença de certos deveres subjacentes à prática do negócio, que poderiam levar à sua descaracterização enquanto doação. A obra de MAUSS já indica a possível existência de traços de reciprocidade: doa-se para retribuir uma doação recebida no passado, ou para vincular o donatário a uma doação futura. A presença de um dever jurídico certamente descaracteriza a doação. Porém, é possível que se doe em cumprimento a deveres extrajurídicos (morais, éticos, religiosos, usos e costumes etc.) e pode-se questionar se a presença desses deveres leva à descaracterização do negócio, em razão da ausência de espontaneidade. Um exemplo nítido desta posição foi o reconhecimento pelo STJ de que o dízimo não é doação, mas ato praticado em cumprimento a "dever de consciência", que não pode ser revogado por ingratidão.

Parece, por outro lado, que seja justificável submeter a regras diferentes atribuições de vantagens sem contrapartida objetivamente iguais caso esteja presente um interesse social relevante, como doações para vítimas de desastres e outras pessoas em situações de vulnerabilidade. Um bom critério, talvez excessivamente tímido, é o que, no Estado de São Paulo, isenta do ITCMD determinadas doações "a entidades cujos objetivos sociais sejam vinculados à promoção dos direitos humanos, da cultura ou à preservação do meio ambiente". O art. $3^{\circ}$, inciso I, da Constituição coloca como um dos objetivos da República a construção de uma sociedade "livre, justa e solidária". Há autores italianos que falam em verdadeiro "adimplemento" de um dever de solidariedade constitucional. Não é necessário chegar a tanto, mas parece razoável que doações efetuadas em atendimento ao objetivo de solidariedade e justiça social não sejam sujeitas à revogação por ingratidão e sejam submetidas a requisitos de forma menos rigorosos. Além disso, pode-se questionar se sobre elas deva prevalecer a proteção da legítima dos herdeiros necessários (embora o “direito de herança" também seja garantido pela carta constitucional - art. 5, XXX).

É desnecessário ressaltar que muitos dos temas tangenciados neste trabalho são altamente complexos e demandam uma análise mais ampla no âmbito da teoria geral do direito e até da filosofia do direito, o que transcende ao objeto da pesquisa, que foi restrito 
à dogmática civilista. Por essa razão, optou-se por adotar uma perspectiva mais de abertura do que de fechamento, no sentido de introduzir novas questões ao debate acadêmico brasileiro sem necessariamente chegar a conclusões definitivas, pois são aspectos que certamente merecem futura reflexão. Espera-se, dessa forma, que as ideias trazidas nesta tese sirvam como ponto de partida para novas considerações acerca do tema. 


\section{REFERÊNCIAS BIBLIOGRÁFICAS}

Albanese, Antonio - Prestazione gratuita, spirito di liberalità e vantaggi indesiderati (il proplema degli scambi imposti), in Contratto e impresa 23 (2007), p. 482-505.

ALPA, Guido, Atto di liberalità e motivi dell'attribuzione, in Riv. trim. dir. proc. civ 26 (1972), p. 354-64.

AlviM, Agostinho - Da doação, $2^{\mathrm{a}}$ ed., São Paulo, Saraiva, 1972.

AMENTA, Gianfranco - La donazione e la sua struttura contrattuale, Torino, Giappichelli, 2002.

ANTUNES VARELA, João de Matos - Das obrigações em geral I (10 ed., $4^{\mathrm{a}}$ reimpr. [2006], Coimbra, Almedina, 2000) e II ( $7^{\mathrm{a}}$ ed., $3^{\mathrm{a}}$ reimpr. [2007], Coimbra, Almedina, 1997).

ARCHI, Gian Gualberto - Donazione (diritto romano), in ED 8 (1964), pp. 930-54.

ARCHI, Gian Gualberto - La donazione - Corso di diritto romano, Milano, Giuffrè, 1960.

ARCHI, Gian Gualberto - Scritti di diritto romano II, in Studi di diritto privato II, Milano, Giuffrè, 1981.

AsCOLI, Alfredo - Sulla legge Cincia, in BIDR 6 (1893), pp. 173-228.

AsCoLI, Alfredo - Trattato delle donazioni, $2^{\mathrm{a}}$ ed., Milano, Libraria, 1935.

Aubry, Charles, e RAU, Charles - Cours de droit civil français d'après la méthode de Zachariae VII, $4^{\mathrm{a}}$ ed., Paris, Maison Cosse, 1847. 
BALBI, Giovanni - Saggio sulla donazione, Torino, Istituto giuridico della R. Università, 1942.

BAUDRY-LACANTINERIE, Gabriel, e COLIn, Ambroise - Traité théorique et pratique de droit civil X-I-Des donations entre vifs et des testaments, Paris, Sirey, 1905.

BERMAn, Harold Joseph - Law and Revolution - The Formation of the Western Legal Tradition, Cambridge, Harvard University Press, 1983.

BESSONE, Mario - Adempimento e rischio, Milano, Giuffrè, 1975.

BETTI, Emilio - Teoria generale delle obbligazioni III - Fonti e vicende dell'obbligazione, Milano, Giuffrè, 1954.

BETTI, Emilio - Teoria generale del negozio giuridico (1943), reed. (2 ${ }^{\mathrm{a}}$ ed., $3^{\mathrm{a}}$ reimpr., 1960), 1ª reimpr. (1994), Napoli, ESI, 2002.

BeviLÁQuA, Clóvis - Direito das obrigações, Salvador, Magalhães, 1896.

Beviláqua, Clóvis - Código Civil dos Estados Unidos do Brasil commentado IV, Rio de Janeiro, Francisco Alves, 1917.

Beviláqua, Clóvis - Projecto de Codigo Civil brazileiro, in Actas dos trabalhos da commissão revisora do Projecto de Codigo Civil brazileiro, Rio de Janeiro, Imprensa Nacional, 1901.

BiAnCA, Cesare Massimo - Diritto civile III - Il contratto, 2ª ed., Milano, Giuffrè, 2000.

BiAnCA, Cesare Massimo - Diritto civile V-La responsabilità, Milano, Giuffrè, 1994. 
BISCONTINI, Guido - Onerosità, corrispettivittà e qualificazione dei contratti - Il problema della donazione mista, Napoli, ESI, 1984.

BIONDI, Biondi - Donazione (diritto romano), in NNDI 6 (1960), pp. 224-30.

BIONDI, Biondo - Donazione (diritto civile), in NNDI 6 (1960), pp. 233-53.

BIONDI, Biondi - Le donazioni, in Vassalli, Filippo (coord.), Trattato di diritto civile italiano XII-IV, Torino, UTET, 1961.

BIOnd, Biondi - Successione testamantaria. Donazioni, in Albertario, Emilio (org.), Trattato di diritto romano X, Milano, Giuffrè, 1943.

BIONDI, Biondo - Scritti giuridici III - Diritto romano. Diritto privato, Milano, Giuffrè, 1965.

BobBio, Norberto - Il positivismo giuridico - Lezioni di Filosofia del diritto raccolte dal dott. Nello Morra, reimpr., Torino, Giappichelli, 1996.

Bodin DE Moraes, Maria Celina - Notas sobre a promessa de doação, in Civilistica.com 2 (2013), pp. 1-19.

BoniLINI, Giovanni - Delle donazioni - artt. 769-809, in Gabrielli, Enrico (org.), Commentario del codice civile, Torino, UTET, 2014.

Bonilini, Giovanni (org.) - Trattato di diritto delle successioni e donazioni VI - Le donazioni, Milano, Giuffrè, 2009.

BozzI, Lucia - Alla ricerca del contratto gratuito atipico, in Riv. dir. civ. 50 (2004), pp. 209-241. 
BRAgA DA CRUZ, Guilherme - Obras esparsas II - Estudos de história do direito; Direito moderno - $2^{a}$ parte, Coimbra, Coimbra, 1981.

BRoISE, Sergio - Animus donandi - Concetto romano e suoi riflessi sulla dogmatica odierna I (Parte generale) e II (Parte speciale; Indici), Pisa, Pacini, 1975.

BROISE, Sergio - Appunti sull'“animus donandi”, in BIDR 67 (1964), pp. 225-46.

CALASso, Francesco - Il negozio giuridico - Lezioni di storia del diritto italiano, Milano, Giuffrè, 1967.

CAmpos Filho, Paulo Barbosa de - O problema da causa no Código Civil brasileiro, São Paulo, Max Limonad, s.d.

Capanema de Souza, Sylvio - Comentários ao novo Código Civil VIII - Das várias espécies de contrato. Da troca ou permuta. Do contrato estimatório, Da doação. Da locação de coisas (arts. 533 a 578), in TEIXEIRA, Sálvio de Figueiredo (coord.), Comentários ao novo Código Civil, Rio de Janeiro, Forense, 2004.

CAPITANT, Henri - De la cause des obligations - Contrats, engagements unilatéraux, legs, $3^{\mathrm{a}}$ ed., Paris, Dalloz, 1927.

CARbonnier, Jean et al. - Des libéralités - Une offre de loi, Paris, Défrenois, 2003.

CAREDDA, Valeria - Le liberalità diverse dalla donazione, Torino, Giappichelli, 1996.

CARnAÚBA, Daniel Amaral, e ReINIG, Guilherme Henrique Lima - Nulidade da doação e conversão substancial do negócio jurídico - Comentários ao acórdão do REsp 1.225.861/RS, in RDCC 1 (2014), pp. 400-09. 
Carnevali, Donazione (diritto civile), in Enc. giur. Treccani 12 (1989), pp. 1-10.

CARneVAli, Ugo - La donazione modale, Milano, Giuffrè, 1969.

Carnevali, Ugo - Le donazioni, in Rescigno, Pietro (org.), Trattato di diritto privato VI - Successioni II, Torino, UTET, 1997.

CARNEVALI, Ugo - Liberalità (atti di), in ED 14 (1974), pp. 214-24.

CarrabBa, Achille Antonio - Donazioni, in Perlingieri, Pietro (org.), Trattato di diritto civile del Consiglio Nazionale del Notariato IV-Autonomia negoziale, Napoli, ESI, 2009.

Carvalho de MendonçA, Manoel Ignácio e Beviláqua, Achilles - Contractos no Direito Civil brasileiro I, $2^{\mathrm{a}}$ ed., Rio de Janeiro, Freitas Bastos, 1938.

Carvalho Santos, João Manoel de - Código Civil brasileiro interpretado XVI - Direito das obrigações (arts. 1.122 - 1.187), 9a ed., Rio de Janeiro, Freitas Bastos, 1964.

Casavola, Franco - Lex Cincia - Contributo alla storia delle origini della donazione romana, Napoli, Jovene, 1960.

CASUlli, Vincenzo Rodolfo - Donazione (diritto civile), in ED 13 (1964), pp. 967-92.

CAsulli, Vincenzo Rodolfo - Donazioni indirette e renunzie ad eredita o legati, Roma, Foro italiano, 1950.

CAtaudella, Antonino - La donazione mista, Milano, Giuffrè, 1970.

CATAudella, Antonino - Sul contenuto del contratto, Milano, Giuffrè, 1966 
Cataudella, Antonino - Scritti sui contratti, Padova, Cedam, 1998.

Cataudella, Antonino - Successioni e donazioni - La donazione, in Bessone, Mario (org.), Trattato di diritto privato V, Torino, Giappichelli, 2005.

CHAMOUn, Ebert - (parecer) Doações sujeitas a termo e condição. Invalidade de cláusula relativa à destinação dos bens após o termo e condição, in Revista Forense 96 (2000), pp. 187-89.

CheCchini, Aldo - L'interesse a donare, in Riv. dir. civ. 22 (1976), pp. 254-317.

Courtis, Christian (org.) - Observar la ley - Ensayos sobre metodología de la investigación jurídica, Madrid, Trotta, 2006.

Couto e Silva, Clóvis Veríssimo do - A obrigação como um processo (1964), reed., Rio de Janeiro, FGV, 2006.

Cunha Gonçalves, Luiz da - Tratado de direito civil em comentário ao Código Civil português VIII-I, $2^{\mathrm{a}}$ ed. (1 ${ }^{\mathrm{a}}$ ed., bras.), São Paulo, Max Limonad, 1956.

D’ANGELo, Antonino - La donazione rimuneratoria, Milano, Giuffrè, 1942.

Dawson, John Philip - Gifts and Promises - Continental and American Law Compared, New Haven, Yale University Press, 1980.

Del Nero, João Alberto Schützer - Conversão substancial do negócio jurídico, Rio de Janeiro, Renovar, 2001.

DÉNOYEZ, Joseph - Les donations visées par la loi Cincia, in IVRA 2 (1951), pp. 146-52. 
D'EtTore, Felice Maurizio - Intento di liberalità e attribuzione patrimoniale - Profili di rilevanza donativa delle obbligazioni di fare gratuite, Padova, Cedam, 1996.

Di BIASE, Antonio - Onerosità e gratuità delle operazioni negoziali complesse, Napoli, ESI, 2010.

Di MAJO, Adolfo - Codice civile con la Costituzione, i trattati U.E. e le principali norme complementari, Milano, Giuffrè, 2010.

DinAmarco, Cândido Rangel - Instituições de direito processual civil II, $2^{\mathrm{a}}$ ed., São Paulo, Malheiros, 2002.

DINIZ, Maria Helena - Curso de direito civil brasileiro III - Teoria das obrigações contratuais e extracontratuais, 27 ed., São Paulo, Saraiva, 2011.

DINIZ, Maria Helena - Sistemas de registros de imóveis, 11ª ed., São Paulo, Saraiva, 2014.

DomAT, Jean - Les lois civiles dans leur ordre naturel, in REMY, Joseph (org.), Oeuvres complètes de J. Domat I - Nouvelle édition, Paris, Firmin Didot, 1828.

Domingues DE ANDRADE, Manuel Augusto - Teoria geral da relação jurídica II - Facto jurídico, em especial negócio jurídico, 4ª reimpr., Coimbra, Almedina, 1974.

ENGISCH, Karl - Einführung in das Juristische Denken, $8^{\mathrm{a}}$ ed., Stuttgart, Kohlhammer, 1983, trad. port. João Baptista Machado, Introdução ao pensamento jurídico, $10^{\mathrm{a}}$ ed., Lisboa, Fundação Calouste Gulbenkian, 10ª ed., 2008

ERPEN, Décio Antonio - Da promessa de doar nas separações judiciais, in RT 77 (1988), pp. 20-27. 
ESPÍNOLA, Eduardo - Dos contratos nominados no direito civil brasileiro, Rio de Janeiro, Gazeta Judiciária, 1953

Felício dos SAntos, Joaquim - Projecto do Codigo Civil brazileiro e commentario V, Rio de Janeiro, Laemmert, 1887.

FENET, Pierre-Antoine - Recueil complet des travaux préparatoires du code civil XII, Paris, Videcoq, 1836.

FERRAZ JÚNIOR, Tercio Sampaio - Introdução ao estudo do direito - Técnica, decisão, dominação, $4^{\mathrm{a}}$ ed., São Paulo, Atlas, 2003.

FERRI, Giovanni Battista - Causa e tipo nella teoria del negozio giuridico, Milano, Giuffrè, 1966.

FERRI, Giovanni Battista - Dall'economia della bontà all'economia del dolore - Saggi di diritto civile, $2^{\mathrm{a}}$ ed., Padova, Cedam, 2005.

GALASSO, Alfredo - Il principio di gratuità, in Riv. crit. dir. priv 19 (2001).

Galasso, Alfredo e MaZzArese, Silvio (org.) - Il principio di gratuità, Milano, Giuffrè, 2008.

Galgano, Francesco - Il negozio giuridico, in Cicu, Antonio, Messineo, Francesco e Mengoni, Luigi (org.), Trattato di diritto civile e commerciale III-I, Milano, Giuffrè, 1988.

Garofalo, Francesco Paolo - La “lex Cincia de donis et muneribus”, in BIDR 15 (1903), pp. $310-12$.

GATT, Lucilla - La liberalità I, Torino, Giappichelli, 2002. 
GATT, Lucilla - Onerosità e liberalità, in Riv. dir. civ. 49 (2003), pp. 655-89.

GHeStin, Jacques - Cause de l'engagement et validité du contrat, Paris, LGDJ, 2006

GiANOLA, Alberto - Atto gratuito, atto liberale - Ai limiti della donazione, Milano, Giuffrè, 2002.

GIANOLA, Alberto - Interesse morale e spirito di liberalità nella giurisprudenza francese, in Riv. dir civ. 49 (2003).

GILISSEN, John - Introduction historique au droit - Esquisse d'une histoire universelle du droit. Les sources du droit. Les sources du droit depuis le XIII. ${ }^{e}$ siècle. Élements d'histoire du droit privé, Bruxelles, Émile Bruyant, 1979, trad. port. de António Manuel Botelho Hespanha e Manuel Luís Macaísta Malheiros, Introdução histórica ao direito, $4^{\mathrm{a}}$ ed., Lisboa, Fundação Calouste Gulbenkian, 2003.

GIORgIAnNI, Michele - Causa (diritto privato), in ED 6 (1960), pp. 547-75.

GIUnTI, Patrizia - Donazione (storia del diritto romano), in Dig. disc. priv., Sez. civ. 7 (1991), pp. 161-76.

Gomes, Orlando, Junqueira de Azevedo, Antônio, e Marino, Francisco Paulo De Crescenzo - Contratos, 26 ${ }^{\mathrm{a}}$ ed., Rio de Janeiro, Forense, 2007.

GOMES, Orlando e BRITO, Edvaldo - Obrigações, 16ª ed., Rio de Janeiro, Forense, 2005.

GoRLA, Gino - Il contratto I - Problemi fondamentali trattati con il metodo comparativo e casistico - Lineamenti generali, Milano, Giuffrè, 1954. 
GRANDI, Dino - Relazione del Ministro Guardasigilli al codice civile - Riproduzione anastatica della G.U. del 4 aprile 1942 a cura del Consiglio Nazionale Forense, introduzioni di Giovanni B. Ferri e Nicola Rondinone, Roma, Istituto Poligrafico e Zecca dello Stato - Libreria dello Stato, 2009.

Grosso, Giuseppe - Causa del negozio giuridico (diritto romano), in ED 6 (1960), pp. 532-35.

HYland, Richard - Gifts - A Study in Comparative Law, reed. (2009), New York, Oxford University Press, 2011.

IRTI, Natalino - Introduzione allo studio del diritto privado, Padova, Cedam, 1990.

IRTI, Natalino - La scienza italiana del diritto alla vigilia del BGB, in Riv. trim. dir. pub. (1997), p. 347, disponível em http://www.direitocontemporaneo.com/wpcontent/uploads/2014/02/IRTI-Scienza-Italiana-e-BGB.pdf [acesso em 11 de setembro de 2015].

ISAMBERT, François-André, e JOURDAN, Athanase-Jean-Léger - Recueil général des anciennes lois françaises XII ([1514-1546] - Depuis l'an 420 jusqu'à la Révolution de 1789, Paris, Belin-Leprieur, 1828) e XXI ([1 ${ }^{\text {er }}$ septembre 1715 -

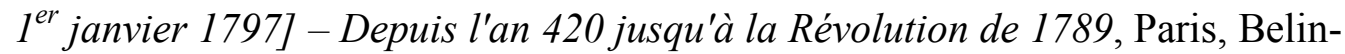
Leprieur, 1830).

Itabaiana de Oliveira, Arthur Vasco e Itabaiana de Oliveira, Aires - Tratado de direito das sucessões II - Da sucessão testamentária, $4^{\mathrm{a}}$ ed., São Paulo, Max Limonad, 1952.

JunqueIRA DE AZEVEDo, Antônio - Estudos e pareceres de direito privado, São Paulo, Saraiva, 2004. 
JunQueIRA DE AZEVEdo, Antônio - Negócio jurídico e declaração negocial - Noções gerais e formação da declaração negocial, Tese (Titularidade), São Paulo, Faculdade de Direito da Universidade de São Paulo, 1986.

JunQueIRA DE AzEVEDo, Antônio - Negócio jurídico - Existência, validade e eficácia, $4^{\mathrm{a}}$ ed., São Paulo, Saraiva, 2002.

LARENZ, Karl - Allgeneiner Teil des deutschen Bürgerlichen Rechts, $3^{\mathrm{a}}$ ed., München, Beck, 1975, trad. esp. Miguel Izquierdo y Macías-Picavea, Derecho civil Parte general, Madrid, Edersa, 1978.

LARENZ, Karl - Methodenlehre der Rechtswissenschaft, 6a ed., Berlin, Springer, 1991, trad. port. José Lamego, Metodologia da ciência do direito, $5^{\mathrm{a}}$ ed., Lisboa, Fundação Calouste Gulbenkian, 2009.

LENZI, Raffaele - Donazione obbligatoria, in Contratto e impresa 19 (2003), pp. 1615-48.

LoNGO, Giannetto - Lex Cincia de donis et muneribus, in NNDI 9 (1957).

LôBo, Paulo Luiz Netto, Comentários ao Código Civil VI - Parte especial - Das várias espécies de contratos (arts. 481 a 564), in JunQUEIRA DE AZEVEDO, Antônio (coord.), Comentários ao Código Civil, São Paulo, Saraiva, 2003.

LOPES, José Reinaldo de Lima - As palavras e a lei - Direito, ordem e justiça na história do pensamento jurídico moderno, São Paulo, Editora 34, 2004.

LOPES, José Reinaldo de Lima - Entre a teoria da norma e a teoria da ação, in STORCK, Alfredo Carlos e LisBoA, Wladimir Barreto (org.), Norma, moralidade e interpretação: temas de filosofia política e de direito, Porto Alegre, Linus, 2009. 
MacCormack, Geoffrey - Gift, Debt, Obligation and the Real Contracts, in LABEO 31 (1985), pp. 131-154.

MADEIRA, Hélcio Maciel França - A advocatio no Direito Romano, Dissertação (Mestrado), São Paulo, Faculdade de Direito da Universidade de São Paulo, 1996.

Malaurie, Philippe - Les successions - Les libéralités, in MALAURIE, Philippe e AynÈS, Laurant, Droit civil, 4a ed., Paris, Defrénois, 2010.

MANZINI, Claudia - "Spirito di liberalità" e controllo giudiziario sull'esistenza della causa donandi, in Contratto e impresa 2 (1985), pp. 409-34.

MANZINI, Claudia - Il contratto gratuito atipico in Contratto e impresa 3 (1986), pp. 90938.

Marrone, Matteo - Istituzioni di diritto romano, $3^{\mathrm{a}}$ ed., Palermo, Palumbo, 2006.

MARKY, Thomas - Curso elementar de direito romano, $8^{\mathrm{a}}$ ed., São Paulo, Saraiva, 1996.

MARTINS-COSTA, Judith Hofmeister - A concha do marisco abandonada e o nomos (ou os nexos entre narrar e normatizar), in RIDB 2 (2013), pp. 4121-57.

MARTINS-COSTA, Judith Hofmeister - O pacto no Sertão roseano - Os pactos, os contratos, o julgamento e a lei, in RIDB 2 (2013), pp. 5227-54.

MAUSS, Marcel - Essai sur le don - Forme e raison de l'échange dans les societés archaïches, Paris, PUF, 1950, trad. port. Marques, António Filipe, Ensaio sobre a dádiva - Forma e razão da troca nas sociedades arcaicas, Lisboa, Edições 70, 2011. 
MaXimiliano, Carlos - Direito das sucessões III, $2^{\mathrm{a}}$ ed., Rio de Janeiro, Freitas Bastos, 1943.

MÉAU-LAutour, Huguette - La donation déguisée en droit civil français - Contribution à la théorie general de la donation, Paris, LGDJ, 1985.

MeliLlo, Generoso - Arnobio e l'ultima vicenda della "lex Cincia”, in LABEO 8 (1962), pp. $62-72$.

Mello, Marcos Bernardes de - Teoria do fato jurídico - Plano da existência, $14^{\mathrm{a}}$ ed., São Paulo, Saraiva, 2007.

Mello, Marcos Bernardes de - Teoria do fato jurídico - Plano da validade, $8^{\mathrm{a}}$ ed., São Paulo, Saraiva, 2008.

Menezes Cordeiro, António Manuel da Rocha e - Da boa fé no direito civil, $3^{\mathrm{a}}$ reimpr. (1983), Coimbra, Almedina, 2007.

Mengoni, Luigi e Realmonte, Francesco - Disposizione (atto di), in ED 13 (1964), pp. 188-95.

MiCHEL, Jacques - Gratuité en droit romain, Bruxelles, Université Libre de Bruxelles Institut de Sociologie, 1961.

Montredon, Jean-François - La désolennisation des libéralités, Paris, LGDJ, 1989.

Moreira Alves, José Carlos - A parte geral do projeto de Código Civil brasileiro Subsídios históricos para o novo Código Civil brasileiro, $2^{\mathrm{a}}$ ed., São Paulo, Saraiva, 2003. 
MoreIRA Alves, José Carlos - Direito romano I (História do direito romano. Instituições de direito romano: A - Parte Geral. B - Parte Especial: Direito das coisas, $13^{\mathrm{a}}$ ed., Rio de Janeiro, Forense, 2005) e II (Instituições de direito romano. B - Parte especial: Direito das obrigações. Direito de família. Direito das sucessões, $6^{\mathrm{a}}$ ed., Rio de Janeiro, Forense, 2005).

Mosco, Luigi - Onerosità e gratuità degli atti giuridici con particolare riguardo ai contratti, Milano, Vallardi, 1942.

Mota Pinto, Carlos Alberto da, Pinto Monteiro, António, e Mota Pinto, Paulo Teoria geral do direito civil, $4^{\mathrm{a}}$ ed., Coimbra, Coimbra, 2005.

MuÑoz, Maria Paula Costa Bertran, Justiça e contrato - Entre comutar e distribuir, Tese (Doutorado), São Paulo, Faculdade de Direito da Universidade de São Paulo, 2010 .

Nery Junior, Nelson, e Nery, Rosa Maria de Andrade - Código Civil comentado, $8^{\mathrm{a}}$ ed., São Paulo, RT, 2011.

Nery Junior, Nelson, e Penteado, Luciano de Camargo - Doação pura, preliminar de doação e contratos de gestão, in RDPriv 7 (2006), pp. 7-58.

OpPo, Giorgio - Adempimento e liberalità, Milano, Giuffrè, 1947.

PAlazZO, Antonio - Atti gratuiti e donazioni, in SACCO, Rodolfo (org.), Trattato di diritto civile - I singoli contratti II, Torino, UTET, 2000.

Palazzo, Antonio - Contenuto e forma, in PAlazzo, Antonio (org.), I contratti di donazione, in RESCIGNO, Pietro e GABRIELLI, Enrico, Trattato dei contratti XI, Torino, UTET, 2009. 
Palazzo, Antonio - Donazione, in Dig. disc. pric., Sez. civ. 7 (1991), pp. 137-61.

Palazzo, Antonio - Le donazioni, in Schlesinger, Piero (org.), Il Codice Civile Commentario - Artt. 769-809, Milano, Giuffrè, 1991.

PELLEGRINI, Lorenzo - La donazione costitutiva di obbligazione, Milano, Giuffrè, 2004.

Peluso, Cezar (coord.) - Código Civil comentado, Barueri, Manole, 2007.

PenteAdo, Luciano de Camargo - Doação com encargo e causa contratual - Uma nova teoria do contrato, $2^{\mathrm{a}}$ ed., São Paulo, RT, 2013.

Penteado, Luciano de Camargo - Direito das coisas, $3^{\text {a }}$ ed., São Paulo, RT, 2014.

PereIRA, Caio Mário da Silva e GAMA, Guilherme Calmon Nogueira da - Instituições de direito civil II - Teoria geral das obrigações, $21^{\mathrm{a}}$ ed., Rio de Janeiro, Forense, 2008.

PereirA, Caio Mário da Silva e Fichtner, Régis - Instituições de direito civil III Contratos. Declaração unilateral de vontade. Responsabilidade civil, $12^{\mathrm{a}} \mathrm{ed}$, Rio de Janeiro, Forense, 2006.

PereirA, Caio Mário da Silva e MoreIRA, Carlos Roberto Barbosa - Instituições de direito civil VI - Direito das sucessões, 16 ${ }^{\mathrm{a}}$ ed., Rio de Janeiro, Forense, 2008.

PeterkA, Nathalie - Les dons manuels, Paris, LGDJ, 2001.

PiCcInINI, Silvia - Profili della donazione dal codice 1865 ad oggi, in Riv. dir. civ. 38 (1992), pp. 173-98. 
Planiol, Marcel Ferdinand - Traité élémentaire de droit civil conforme au programme officiel des facultés de droit II (Les preuves. Théorie générale des obligations. Les contrats. Prtivilèges et hypothèques, $2^{\mathrm{a}} \mathrm{ed}$, Paris, Cotillon, 1902) e III (Régimes matrimoniaux. Successions. Donations et testaments, $7^{\mathrm{a}}$ ed., Paris, LGDJ, 1918).

PringSheIM, Fritz - Animus in Roman Law, in L. Q. Rev. 49 (1933), pp. 43-60.

Pires de Lima, Fernando Andrade, e Antunes Varela, João de Matos - Código civil anotado II - Artigos $762^{\circ}$ a $1250^{\circ}, 4^{\mathrm{a}}$ ed., Coimbra, Coimbra, 1997.

PisANELLI, Giuseppe - Relazione del Ministro sul terzo libro del progetto, in Raccolta dei lavori preparatori del codice civile del Regno d'Italia I, Palermo-Napoli, Pedone Lauriel, 1866.

Pontes de Miranda, Francisco Cavalcanti, Tratado de direito privado XLVI - Parte especial - Direito das obrigações: Contrato de seguro (continuação). Seguro de vida. Seguros de acidentes pessoais. Seguro de responsabilidade. Seguro de crédito. Seguro de riscos especiais e de universalidade. Seguros mútuos. Resseguro. Contrato de comodato. Contrato de doação. Contrato de hospedagem, $3^{\text {a }}$ ed., Rio de Janeiro, Borsoi, 1972.

PoSNER, Richard - Gratuitous Promises in Economics and Law, in The Journal of Legal Studies 6 (1977), pp. 411-426.

Pothier, Robert - Traité des obligations, in Oeuvres complètes de Pothier I - Nouvelle édition - Traité des obligations, Paris, Thomine et Fortic, 1821.

PothIER, Robert - Traité des donations entre-vifs, in Oeuvres complètes de Pothier XXIII - Nouvelle édition - Traités des donations entre-vifs, des personnes et des choses, Paris, Thomine et Fortic, 1821. 
PousadA, Estevan Lo Ré - Preservação da tradição jurídica luso-brasileira: Teixeira de Freitas e a Introdução à Consolidação das Leis Civis, Dissertação (Mestrado), São Paulo, Faculdade de Direito da Universidade de São Paulo, 2006.

Rangel, Leyla Castello Branco, e LoPes, Carlos Alberto de S. (org.) - Código Civil: anteprojetos III (Anteprojetos de Código de Obrigações) e V-II (Anteprojeto de Código de Código Civil - revisto [1973]), Brasília, Senado Federal Subsecretaria de Edições Técnicas, 1989.

RAYNAUd, Pierre - Les successions et les libéralités, in MARTY, Gabriel, e RAYNAUD, Pierre, Droit civil, Paris, Sirey, 1983.

REALE, Miguel - Lições preliminares de direito, $27^{\mathrm{a}}$ ed., 15 $5^{\mathrm{a}}$ reimpr. (2015), São Paulo, Saraiva, 2002.

Reimann, Mathias e Zimmermann, Reinhard (org.) - The Oxford Handbook of Comparative Law (2006), reed., Oxford, Oxford University Press, 2008, pp. 405 e 407.

RESCIGNO, Pietro - Note sull'interpretazione degli atti di liberalità, in Vita notarile 50 (1998), pp. 61-69.

RodotÀ, Stefano - La vita e le regole - Tra diritto e non diritto, reed. (2006), Milano, Feltrinelli, 2009.

RodotÀ, Stefano - Solidarietà - Un'utopia necessaria, Roma, Laterza, 2014.

RopPO, Vincenzo - Il contratto, in IUdiCA, Giovanni e ZATTI, Paolo (org.), Trattato di diritto privato, Milano, Giuffrè, 2001. 
Rosado de Aguiar JÚNIOR, Ruy (coord.) - Enunciados aprovados na VI Jornada de Direito Civil, Brasília, Centro de Estudos Judiciários do Conselho da Justiça Federal, 2013, disponível em http://www.cjf.jus.br/cjf/CEJ-Coedi/jornadascej/vijornada.pdf [acesso em 15 de agosto de 2015].

SACCO, Rodolfo e DE Nova, Giorgio - Il contratto I, $3^{\mathrm{a}}$ ed., in Sacco, Rodolfo (org.), Trattato di diritto civile - Le fonti delle obbligazioni I, Torino, UTET, 2004.

Salama, Bruno Meyerhof e PARgendler, Mariana - Direito e consequência no Brasil Em busca de um discurso sobre o método, in RDA 262 (2013), p. 130.

Sanseverino, Paulo de Tarso Vieira, Contratos nominados II - Contrato estimatório, doação, locação de coisas, empréstimo (mútuo - comodato), in REALE, Miguel e MARTIns-Costa, Judith Hofmeister - Estudos em homenagem ao Professor Miguel Reale IV, São Paulo, RT, 2005.

SAVIGNY, Friedrich Carl von - System des heutigen römischen Rechts, trad. it. Scialoja, Vittorio, Sistema del diritto romano attuale IV, Torino, UTET, 1889.

SCHMIDT, Jan Peter - Vida e obra de Pontes de Miranda a partir de uma perspectiva alemã - Com especial referência à tricotomia "existência, validade e eficácia do negócio jurídico", in RFDC 3 (2014), pp. 135-58, disponível em http://www.direitocontemporaneo.com/wpcontent/uploads/2014/02/SCHMIDT-

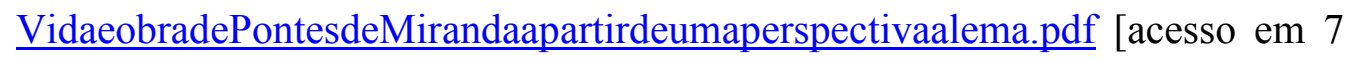
de setembro de 2015].

SCOZZAFAVA, Oberdan Tommaso - La qualificazione di onerosità o gratuità del titolo, in Riv. dir. civ. 26 (1980).

SÉRIAUX, Alain - Les succession. Les libéralités, Paris, PUF, 1986. 
TAlamanCA, Mario - Donazione possessoria e donazione traslativa, in BIDR 64 (1961), pp. 249-83.

TALAMANCA, Mario - Istituzioni di diritto romano, Milano, Giuffrè, 1990.

TeiXeIRA De Freitas, Augusto - Consolidação das Leis Civis, $3^{\mathrm{a}}$ ed., Rio de Janeiro, Garnier, 1876.

TeiXeira de Freitas, Augusto - Esboço do Código Civil II, reimpr., Brasília. Ministério da Justiça - Fundação Universidade de Brasília, 1983.

Torrente, Andrea - La donazione, in Cicu, Antonio e Messineo, Francesco (org.), Trattato di diritto civile e commerciale XXII, Milano, Giuffrè, 1956.

Troplong, Raymond-Théodore - Des donations entre-vifs et des testaments I in Droit civil expliqué - Commentaire du Titre II du Livre III du Code Napoléon, $2^{\mathrm{a}} \mathrm{ed}$, Paris, Administration du Journal des Notaires et des Avocats, 1862.

VECCHIO, Gianfrancesco - Le liberalità atipiche, reed.,Torino, Giappichelli, 2006.

Veloso, Zeno - Comentários ao Código Civil XXI - Parte especial - Do direito das sucessões - Da sucessão testamentária; Do inventário e da partilha (Artigos 1.857 a 2.027), in JunQueIRA DE AzEVEdo, Antônio (coord.), Comentários ao Código Civil, São Paulo, Saraiva, 2003.

VillelA, João Baptista - Contrato de doação - Pouca luz e muita sombra, in PereIRA Júnior, Antonio Jorge; e JABUR, Gilberto Haddad (coord.), Direito dos contratos, São Paulo, Quartier Latin, 2006.

VocI, Pasquale - Tradizione, donazione e vendita da Costantino a Giustiniano, in IURA 38 (1987), pp. 72-148. 
VVAA - Scintillae iuris - Studi in memoria di Gino Gorla III - Contratto, responsabilità, proprietà, impresa e società, processo, amministrazione pubblica, Milano, Giuffrè, 1994.

VVAA - Studi in memoria di Emilio Albertario I, Milano, Giuffrè, 1953.

VVAA - Studi in memoria di Filippo Vassalli II, Torino, UTET, 1960.

WALD, Arnoldo - (parecer) Do regime jurídico da doação de bens móveis feita por ascendente a descentente, in Revista Forense 89 (1993), pp. 139-45.

WINDSCHEID, Bernhard - Lehrbuch des Pandektenrechts, 1900, trad. it. Fadda, Carlo e Bensa, Paolo Emilio, Diritto delle Pandette II-II, Torino, UTET, 1904.

ZIMMERMANN, Reinhard - Roman Law, Contemporary Law, European Law - The Civilian Tradition Today, Oxford, Orford University Press, 2001.

ZimmermanN, Reinhard - The Law of Obligations - Roman Foundations of the Civilian Tradition, London, Oxford University, 1996.

ZWEIGERT, Konrad e KöTZ, Hein - Einführung in die Rechtsvergleichung auf dem Gebiete des Privatrechts, 1971, trad. ing. Tony Weir, Introduction to Comparative Law, $3^{\text {a }}$ ed., Oxford, Oxford University Press, 1998. 